Morten A. Horn,

Daniel Joachim H. Kleiven

og Morten Magelssen (red.)

Dødshjelp i Norden?

Etikk, klinikk og politikk 
Dødshjelp i Norden?

Etikk, klinikk og politikk 

Morten A. Horn, Daniel Joachim H. Kleiven og Morten Magelssen (red.)

\section{Dødshjelp i Norden? Etikk, klinikk og politikk}


(C) 2020 Morten Andreas Horn, Daniel Joachim Heggheim Kleiven, Morten Magelssen, Theo A. Boer, Siri Brelin, Christian Juul Busch, Anne-Berit Ekström, Jan Grue, Ole Hartling, Søren Holm, Mikaela Luthman, Kalle Mäki, Sven Román og Fabian Ståhle.

Dette verket omfattes av bestemmelsene i Lov om opphavsretten til åndsverk m.v. av 1961. Verket utgis Open Access under betingelsene i Creative Commons-lisensen CC-BY 4.0 (http://creativecommons.org/licenses/by/4.o/). Denne tillater tredjepart å kopiere, distribuere og spre verket i hvilket som helst medium eller format, og å remixe, endre, og bygge videre på materialet til et hvilket som helst formål, inkludert kommersielle, under betingelse av at korrekt kreditering og en lenke til lisensen er oppgitt, og at man indikerer om endringer er blitt gjort. Tredjepart kan gjøre dette på enhver rimelig måte, men uten at det kan forstås slik at lisensgiver bifaller tredjepart eller tredjeparts bruk av verket.

ISBN trykt bok: 978-82-02-67764-o

ISBN PDF: 978-82-02-61657-1

ISBN EPUB: 978-82-02-67761-9

ISBN HTML: 978-82-02-67762-6

ISBN XML: 978-82-02-67763-3

DOI: https://doi.org/10.23865/noasp.96

Dette er en fagfellevurdert antologi. Kapittel 13 er basert på en artikkel tidligere publisert i International Journal of Environmental Studies (se https://doi.org/10.1080/00207233.2017. 1415834). Kapitlet er gjengitt og oversatt til svensk med tillatelse fra Taylor \& Francis og er ikke omfattet av bokens lisens.

Dette er 1. utgave 2. reviderte opplag av boken som først ble utgitt 13. mai 2020. Revideringen gjelder kapittel 13 .

Omslagsdesign: Cappelen Damm AS

Cappelen Damm Akademisk/NOASP

noasp@cappelendamm.no 


\section{Innhold}

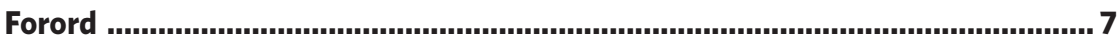

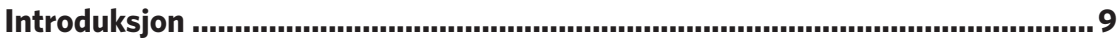

Del I: Dødshjelp i Norden ......................................................................... 19

Kapittel 1 Fem spor i dødshjelpsdebatten ...................................................21

Morten A. Horn og Morten Magelssen

Kapittel 2 Språk og virkelighet i dødshjelpsdebatten ....................................35

Morten Magelssen

Kapittel 3 Dødshjelp: Lovverk, praksis og holdninger i de skandinaviske land .51

Daniel Joachim H. Kleiven, Ole Hartling, Fabian Ståhle,

Morten A. Horn og Morten Magelssen

Kapittel 4 Dödshjälpsdebatten i Finland........................................................... 75

Kalle Mäki

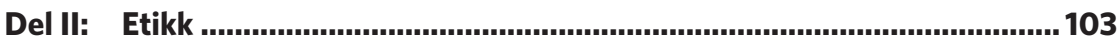

Kapittel 5 Legalisering af dødshjælp - den indirekte afvisning ................... 105 Ole Hartling

Kapittel 6 Autonomi er noget vi giver hinanden......................................... 125 Christian Juul Busch

Kapittel 7 De to veiene til dødshjelp ........................................................141 Daniel Joachim H. Kleiven

Kapittel 8 Fortellinger om død, verdsetting av liv .......................................... 157 Jan Grue

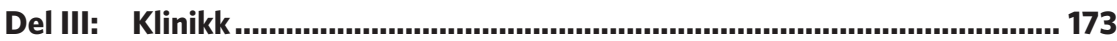

Kapittel 9 En leges nei til dødshjelp ................................................................. 175

Morten A. Horn 
Kapittel 10 Kan lindrende behandling fjerne behovet for dødshjelp?

Siri Brelin

Kapittel 11 Psykiatri och dödshjälp

Sven Román

Kapittel 12 Er det at blive gammel tilstrækkelig årsag til dødshjælp?

235

Søren Holm

Del IV: Politikk

Kapittel 13 Erfarenheter från femtio år med dödshjälp i Nederländerna....... 251

Theo A. Boer

Kapitel 14 En kritisk granskning av Oregonmodellen 275

Anne-Berit Ekström og Mikaela Luthman

Kapittel 15 Er det mulig å lage en entydig, rettferdig

og forsvarlig dødshjelpslov?

Morten A. Horn

Takk.

Om forfatterne 


\section{Forord}

Som folkevalgte har vi en grunnleggende forpliktelse til å lese, høre og forstå de mest relevante argumentene mot dødshjelp før man trykker «ja» eller «nei» $i$ en votering. Vi er derfor avhengig av en kunnskapsbasert debatt om dødshjelp, og denne boken bidrar svært godt til akkurat det. Boken gir en grundig og nyansert oversikt over de mest relevante argumentene mot dødshjelp.

Det er et tema for de lange tanker, der vi blir nødt til å trekke inn alt fra individuelle behov til universelle konsekvenser. Kan dødshjelp i det hele tatt legaliseres - på en entydig, rettferdig og forsvarlig måte? Dersom det handler om selvbestemmelse, hvorfor er det kun noen som skal eie den selvbestemmelsen? Dersom dødshjelp legaliseres, hvilke signaler sender samfunnet til mennesker som oppfyller de politisk bestemte kriteriene for å motta dødshjelp? Dersom vi innfører et regelverk som regulerer vilkårene for å kunne kreve dødshjelp, bidrar vi ikke samtidig til å si noe om hvilke mennesker som lever verdifulle liv, og hvilke mennesker som ikke gjør det - i våre øyne?

Og hva er livskvalitet og verdighet? I en hektisk hverdag reflekterer vi sjelden over hva som gir livet kvalitet og mening. De fleste tenker ikke over livets skjørhet, ensomhet og sårbarhet, at vi i realiteten er avhengige vesener, og at vi må forstås $i$ lys av vår kultur, vår historie, og vårt forhold til andre mennesker og til samfunnet. Autonomi er selvsagt en viktig del av det å leve gode og verdige liv, men det er ikke tilstrekkelig.

Vi tenker også sjelden over samfunnet som en organisme. I ethvert samfunn skjer det gradvis og umerkelig verdiglidninger. Det er dette motstandere av dødshjelp kaller «skråplanseffekten». Bekymringen for at dødshjelp, når den blir legalisert, vil normaliseres og bli brukt i stadig flere situasjoner og på flere pasientgrupper. At vi ikke vil klare å motstå en slik utvikling da det er $v i$ som glir, jevnført med våre tidligere verdier. Dessverre fremstår ofte argumentet om skråplanseffekten som en 
karikering av motstandernes intensjoner i den politiske debatten. Det er uheldig. Alle har en egeninteresse av at debatten om dødshjelp er nyansert, og at den tas med innestemme.

For debatter om døden, og om livets eksistensielle vilkår, er også høyst personlige. Enten vi er pårørende, pasienter eller friske samfunnsborgere som undrer oss over hvordan vi ville håndtert en situasjon der alle våre livsbetingelser endret seg.

I det øyeblikket man tror man har en oversikt over de etiske, juridiske og medisinske spørsmålene rundt dødshjelp, møter man flere nyanser og perspektiver. Det gjør dødshjelp til et krevende spørsmål for oss som politikere, men også som medmennesker.

Selv om undertegnede har vært uttalte motstandere av å innføre dødshjelp i Norge, er ikke boken forbeholdt våre meningsfeller. Det er en bok som alle, også forkjempere av dødshjelp, bør lese og diskutere. Skråsikkerhet har ikke plass i denne debatten.

Kjersti Toppe, stortingsrepresentant, Senterpartiet

Mathilde Tybring-Gjedde, stortingsrepresentant, Høyre 


\section{Introduksjon}

Bør dødshjelp - eutanasi og assistert selvmord - bli tillatt? Over hele den vestlige verden diskuteres spørsmålet. Nederland var først ute med legalisering. Holdningene hadde endret seg fra 1970-tallet, og i 1984 frikjente nederlandsk høyesterett en lege som hadde utført dødshjelp. Samtidig knesatte retten retningslinjer som, når de ble fulgt, skulle frita leger for straff. Dødshjelp ble snart utbredt praksis. Retningslinjene dannet grunnlaget for formell legalisering av dødshjelp i 2001. Året etter vedtok også Belgia en dødshjelpslov. Senere har Luxembourg, Colombia og Canada tillatt dødshjelp. I 1997 legaliserte den amerikanske staten Oregon legeassistert selvmord, og hittil har ytterligere ni delstater fulgt etter. Den australske delstaten Victoria innførte dødshjelp i 2019, og Western Australia følger etter i 2021. I tillegg har Sveits lenge åpnet for assistert selvmord.

Samtidig er det ingen entydig liberaliseringsbølge: Flere land, deriblant Storbritannia og Finland, har tatt forslag om legalisering opp til vurdering i parlamentet, men endt med å avvise dem.

Dødshjelpsdebatten intensiveres også i de nordiske landene. Verdigrunnlaget har de nordiske naboene i stor grad til felles, og diskusjonen om dødshjelp følger i hovedsak samme mønster fra land til land. Men dybden og presisjonen i debatten er ofte lav, og i runde etter runde gjentas variasjoner over de samme argumentene. Vi håper at denne boken kan bringe de nordiske dødshjelpsdebattene et skritt videre.

I bokens 15 kapitler drøftes dødshjelpsspørsmålet fra ulike innfallsvinkler. Spørsmålet om dødshjelp er definitivt ikke et rent medisinsk spørsmål, selv om medisinsk-faglige premisser er et essensielt grunnlag for diskusjonen. På samme måte er dødshjelp heller ikke et rent fagetisk spørsmål, hvis etikk forstås som en gren av filosofien. Dødshjelp involverer grunnleggende spørsmål om det gode liv og den gode død, om livskvalitet og mening, og om selvbestemmelse og fellesskap i det liberale demokratiet. Noen momenter er primært teoretiske, andre primært 
empiriske. Ett enkelt faglig perspektiv kan derfor ikke ha forrang når dødshjelp skal belyses. Bokens forfattere har bakgrunn fra ulike fag: medisin, filosofi, medisinsk etikk, teologi og språkvitenskap er representert. Og en slik liste tydeliggjør at siste ord heller ikke er sagt i og med denne boken. Fag som juss, sosiologi, antropologi, psykologi, sykepleie og andre helsefag vil også kunne yte viktige bidrag.

Med ett unntak (nederlenderen Theo A. Boer) kommer forfatterne fra Danmark, Finland, Sverige og Norge, og skriver på sine respektive skandinaviske språk. Vi vet at mange synes det er krevende å lese tekster på nabospråkene. For å lette lesningen har vi til slutt i hvert kapittel laget en ordforklaring med noen av de ordene som av erfaring oftest byr på problemer. I sum synliggjør bidragene at vi har mye å lære av hverandre på tvers av landegrensene, men samtidig at de grunnleggende spørsmålene som må belyses, dypest sett er de samme.

Denne boken gir seg ikke ut for å være nøytral om det polariserte spørsmålet om legalisering av dødshjelp. Den har en tydelig grunntone i form av en kritisk innstilling til legalisering. Hovedtyngden ligger på argumenter som taler mot slik legalisering, samtidig som argumenter for legalisering også vurderes kritisk. Vårt ønske er at boken skal være nyttig for alle som vil sette seg grundig inn i dødshjelpsspørsmålet og forstå de beste argumentene mot dødshjelp.

\section{Dødshjelp i Norden}

Boken er inndelt i fire seksjoner. I den første, «Dødshjelp i Norden», blir grunnbegrepene definert og temaene i den offentlige debatten systematisert. Lovverk, praksis og holdninger i Danmark, Finland, Sverige og Norge blir beskrevet. I kapittel 1, «Fem spor i dødshjelpsdebatten», argumenterer Morten A. Horn og Morten Magelssen for at dødshjelpsdebatten kan deles inn i fem «hovedspor»: Grunnleggende spørsmål om liv og død; retten til å bestemme over egen død og selvbestemmelsens grenser; hjelperens rolle; helsefaglige premisser; og debatten om legalisering og andre lands erfaringer. Utgangspunktet er observasjonen av at dødshjelpsdebatter i det offentlige rom ofte kan bli uoversiktlige, fordi debattanter snakker forbi hverandre - ikke «følger samme spor». Kapitlet 
identifiserer noen av de aller mest sentrale spørsmålene i hvert «spor», og peker også på forbindelseslinjer til de øvrige kapitlene i boken.

Også kapittel 2, «Språk og virkelighet i dødshjelpsdebatten», springer ut av det faktum at debattantene ikke alltid snakker om det samme. Magelssens forslag er at dødshjelpsdebatten bør bygge på et presist sett definisjoner. I dette kapitlet definerer han et sett grunnbegreper som skal være egnet for dødshjelpsdiskusjon på de skandinaviske språkene. Begrepsparet «aktiv» og «passiv dødshjelp» forkastes, og det norske begrepet «behandlingsbegrensning» fremheves som en egnet betegnelse på å avslutte eller ikke starte potensielt livsforlengende behandling. Kapitlet avsluttes med en utforskning av skillelinjene mellom dødshjelp og slik behandlingsbegrensning.

I kapittel 3, «Dødshjelp: Lovverk, praksis og holdninger i de skandinaviske land» redegjør Daniel Joachim H. Kleiven, Ole Hartling, Fabian Ståhle, Horn og Magelssen nettopp for lovverk, praksis og holdninger i sine respektive land. De identifiserer flere likheter. Blant annet er det et felles mønster at mens majoriteten av leger og politikere er kritisk til legalisering av dødshjelp, synes majoriteten av befolkningen å være mer positiv. Samtidig er det viktig å reflektere over holdningsundersøkelsenes rolle. I hvilken grad bør slike undersøkelser danne grunnlag for politikken?

I Finland har parlamentet nylig tatt stilling til et forslag om å legalisere dødshjelp. I kapittel 4, «Dödshjälpsdebatten i Finland», redegjør Kalle Mäki for prosessen rundt forslaget som ble fremmet som et «medborgerinitiativ» i 2017. Mäkis analyse peker på at helsepersonell hadde en helt sentral - kanskje avgjørende - rolle i debatten. Ved å fremheve hvor mye lindrende medisin kan utrette, men samtidig hvor store udekkede behov det er i denne delen av helsetjenesten, ble den politiske oppmerksomheten dreiet over mot å styrke tilbudet om lindrende behandling til døende. Forslaget om legalisering av dødshjelp ble derimot nedstemt. Det ligger lærdom i dette for de andre nordiske landene.

\section{Etikk}

Andre seksjon, «Etikk», består av fire kapitler. Selvbestemmelse autonomi - er et viktig tema i dødshjelpsdebatten. Alle borgeres råderett 
over eget liv og rett til selvbestemmelse er utgangspunktet for et av de mest grunnleggende argumentene for dødshjelp. Men vilkårene for autonomi må utforskes nærmere, og det gjøres på ulikt vis i kapitlene 5, 6 og 7. Ole Hartlings kapittel har fått tittelen «Legalisering af dødshjælp - den indirekte afvisning». Hartling hevder at den egentlige rettferdiggjørelsen av dødshjelp må være at visse liv vurderes som ikke leveverdige. Men når et system for dødshjelp basert på et slikt premiss settes i system, er det fare på ferde: Hvis en lidende og fortvilet person blir møtt av en oppfatning om at det er rasjonelt og rett av vedkommende å ønske sin egen død, er budskapet samtidig at denne personen er en som fellesskapet kan klare seg uten. Hartling beskriver den «indirekte avvisning» som på denne måten kan ligge i en legalisering av dødshjelp, til tross for den tilsynelatende respekten for autonomi som tilbudet om dødshjelp er til for å ivareta.

I sitt kapittel, «Autonomi er noget vi giver hinanden», viser Christian Juul Busch til at vi i Norden har tradisjon for å tenke bredere om individets selvbestemmelse enn i den anglo-amerikanske tradisjonen. Mens sistnevnte er sterkt individualistisk, vil en nordisk forståelse av autonomi også romme gjensidig forpliktelse - innad i relasjoner, og mellom samfunn og individ. Det får betydning for hvordan vi bør tenke om dødshjelp.

I «De to veiene til dødshjelp» viser Daniel Joachim H. Kleiven at dødshjelp begrunnes ad to veier: Enten i personens selvbestemmelse, eller i at personen har rasjonelle, gode grunner for sitt dødsønske. Hvor havner vi hvis vi følger hver av veiene til sin logiske endestasjon? Ved nærmere ettersyn er det særlig den andre veien dagens dødshjelpslover går, slik også Hartling vurderer det i sitt kapittel. Det er personens grunner for dødshjelp som begrunner tilbudet om dødshjelp, mens autonomiprinsippet snarere enn å begrunne dødshjelp kun bidrar til å avgrense hvem som skal få det. Kleivens bidrag vil vise at et slikt prosjekt forplikter oss til å sette kriterier for hva som skal kvalifisere som gode grunner for dødshjelp, og at dette samtidig formidler en problematisk oppfatning av hva som er et leveverdig liv.

Seksjonen avsluttes med kapittel 8, «Fortellinger om død, verdsetting av liv», av Jan Grue. Han gir en kritisk analyse av fortellingene om dødshjelp i offentligheten. Fortellinger former våre kulturelle forestillinger 
og fungerer som indirekte argumenter, hevder Grue. Mønstrene i noen kulturelt sentrale fortellinger om dødshjelp, og hvilket verdisyn, menneskesyn og syn på liv, død, mening og lidelse de uttrykker, er vel verdt å granske nærmere.

\section{Klinikk}

Helsefaglige premisser er essensielle for dødshjelpsdebatten. I de nordiske landene er de fleste leger avvisende til legalisering av dødshjelp. Men hvorfor er det slik? I den akademiske litteraturen kan legenes erfaringsbaserte argumenter fort bli usynlige: forskningslitteraturen domineres av deskriptive empiriske undersøkelser av medisinske beslutninger ved livets slutt, og av normative analyser som gjerne føres i pennen av filosofer. Med kapittel 9, «En leges nei til dødshjelp», ønsker Morten A. Horn å vise hvordan dødshjelpsspørsmålet kan se ut fra innsiden av sykehuset. Hvis dødshjelp skulle legaliseres i Norden, vil samfunnet trolig forvente at legene er de som skal utføre det. Horn begynner med å tilkjennegi et tvisyn: Mange leger vil ha sympati for argumentene for dødshjelp, og kunne ha ønsket å ha dødshjelp som en tilgjengelig mulighet «aller nederst i legekofferten». Men viktige hensyn knyttet til legens rolle og profesjonsetikk taler imot legalisering, og Horn presenterer åtte argumenter. Ikke minst handler det om at legen må være en som avviser at menneskets verdighet kan knyttes til funksjonsevne.

I kapittel 10 spør Siri Brelin: «Kan lindrende behandling fjerne behovet for dødshjelp?» Hun redegjør for filosofien bak lindrende (palliativ) behandling og hvordan den forsøker å se pasienten som et helt menneske, med behov som går ut over det rent biomedisinske. Det å se pårørende og deres behov og relasjon til pasienten er også nødvendig i helhetlig lindrende omsorg. Brelin viser hvordan lindrende sedering kan være et godt alternativ, som en siste utvei, når mer konvensjonell behandling ikke gir tilstrekkelig lindring. Behandlingen har vært omdiskutert, men er ikke egentlig etisk problematisk når den brukes innenfor retningslinjene. I sum viser kapitlet hvordan høykvalitets lindrende behandling har mye å by på for å gi pasienter livskvalitet i livets siste fase og en verdig død. 
I kapittel 11, «Psykiatri och dödshjälp», problematiserer Sven Román forholdet mellom psykisk helse og dødshjelp. Legaliseringstilhengere går gjerne ut fra at personer som ønsker dødshjelp på den ene siden, og «tradisjonelle» selvmordstruende pasienter med psykiske lidelser på den andre, er to helt distinkte grupper. Románs bidrag viser at det ikke er så enkelt. Dermed blir det heller ikke uproblematisk for helsetjenesten å tilby dødshjelp til den første gruppen, samtidig som den andre gruppen med alle midler skal hindres i sitt forsett. Psykiske helsetjenester betrakter suicidalitet som symptom på en tilstand som kan behandles, og har også ofte effektiv behandling å tilby.

I kapittel 12, «Er det at blive gammel tilstrækkelig årsag til dødshjælp?», gir Søren Holm en kritisk vurdering av forslaget om rett til dødshjelp til alle over 75 år som ber om det. Dette radikale forslaget har nådd det nederlandske parlamentet, og kan i seg selv fortolkes som et utslag av den verdiglidningen som har funnet sted i Benelux-landene når det gjelder dødshjelp og død. Holm viser hvorfor et rent alderskriterium for rett til dødshjelp bør avvises også av de som prinsipielt aksepterer dødshjelp. Videre sannsynliggjør han at introduksjon av et alderskriterium kan føre til særlig sterkt press mot sårbare eldre.

\section{Politikk}

Hvis dødshjelp skal bli en etablert praksis, må den før eller siden bli et politisk spørsmål. Da trer utfordringen med å lage en god lov i forgrunnen, og erfaringer fra land som har legalisert dødshjelp, blir ytterst relevante. Kapittel 13 presenterer viktig kunnskap om utviklingen i Nederland. Som det første landet som aksepterte dødshjelp, er Nederland et viktig samfunnsmessig «laboratorium». Theo A. Boers kapittel, «Erfarenheter från femtio år med dödshjälp i Nederländerna», er bemerkelsesverdig av flere grunner. For det første er det skrevet av en prinsipiell tilhenger av legal dødshjelp som over tid har blitt kritisk til flere sider ved nederlandsk dødshjelpspraksis. For det andre gir nettopp Boers store erfaring, gjennom mangeårig medlemskap i en av granskningskomiteene som gjennomgår dødshjelpssaker, innblikk i utviklingstrekk som ellers ikke er fremme i lyset. Boers bekymring dreier seg særlig 
om fire forhold: Antallet dødshjelpstilfeller har økt kraftig, dødshjelp innvilges med stadig nye begrunnelser, en voksende andel har lang forventet gjenværende levetid, og prosessen frem til dødshjelp er blitt mer strømlinjeformet med færre barrierer. Boers kapittel bør være av stor interesse for nordiske debattanter som følger med på «det nederlandske eksperimentet».

Mange ser utviklingen i nederlandsk dødshjelpspraksis som bekymringsverdig. Blant annet av denne grunn fremheves Oregon-modellen ofte som en alternativ rettslig regulering av dødshjelp som kunne ha passet for de nordiske landene. I kapittel 14, «En kritisk granskning av Oregonmodellen», viser Anne-Berit Ekström og Mikaela Luthman at også denne modellen har store svakheter. Overfladiskheten og hullene i Oregon-modellens kontroll blir spesielt slående når vi tar i betraktning hvordan samfunnet regulerer andre høyrisikovirksomheter. En virksomhet der feil bokstavelig talt kan få dødelige konsekvenser, må underlegges mye grundigere kontroll enn det dødshjelp er gjenstand for i Oregon.

Hvis dødshjelp først skulle legaliseres, hvordan burde loven utformes? Boken avsluttes med kapittel 15, «Er det mulig å lage en entydig, rettferdig og forsvarlig dødshjelpslov?». Morten Horn argumenterer her for at en dødshjelpslov må oppfylle tre kriterier for å være akseptabel: Den må for det første være entydig, ved at den ikke etterlater tvil om hvilke pasienter som kvalifiserer til dødshjelp, og hvilke krav som må være oppfylt. Den må for det andre være rettferdig, ved at relevant like tilfeller behandles likt. Hvis loven åpner for dødshjelp for én gruppe, må den også åpne for dødshjelp for en annen gruppe med like stort eller større behov. Hvis ikke vil loven være ustabil ved at den - med rette - vil bli kritisert for å være urettferdig. Loven må for det tredje være forsvarlig, ved at den krever kontrollsystemer som hindrer utglidning og misbruk. Horn vurderer også kort eksisterende dødshjelpslover, med spesiell oppmerksomhet på Canada. Hans vurdering er at både den kanadiske loven og andre dødshjelpslover mislykkes i å oppfylle kriteriene. Hvis ingen eksisterende dødshjelpslover oppfyller disse elementære kravene, er det i seg selv et kraftfullt argument mot at Norden skal følge i de dødshjelpsliberale landenes fotspor. 


\section{Dødshjelpsfri sone i Norden?}

Gjennomgående setter bidragsyterne til denne boken ord på bekymringen for hva legalisering av dødshjelp kan føre til, og på argumentene som begrunner en slik bekymring. Men det er ikke av den grunn en «negativ» bok ført i pennen av dystre pessimister. Dødshjelpsmotstanderne - både i denne boken og i de ulike nordiske samfunn - kan ha ulike livssyn, og de kan vektlegge ulike argumenter. Men vi tror de gjerne i grove trekk deler en visjon av det gode samfunn:

Vi i Norden har bygget samfunn der fellesskap, gjensidig avhengighet og omsorg for hverandre er sentrale bærebjelker. Men vi ser hos oss, som i resten av den vestlige verden, en fremvekst av individualisme, og at de teknologiske mulighetene stadig oftere styrer samfunnsutviklingen på bekostning av våre grunnleggende verdier. Mange av oss, ikke minst $\mathrm{i}$ helseprofesjonene, står i en tradisjon som er i opposisjon til denne utviklingen. Vi ser det som naturlig og riktig at de svake skal støttes av de sterke, og at ethvert individ gjennom livet kan være både sårbart og sterkt i ulike faser. Vi lever i samfunn omgitt av hjelpetrengende mennesker, der både det å yte og det å motta hjelp er noe av formålet med å ha et samfunn. Vi ser at mange mennesker har egenskaper som gjør dem svakere og mer sårbare enn andre, og selv de som virker selvsikre og usårlige, kan ha skjulte sider som gjør dem svake.

Det er tenkelig at innføring av dødshjelp i våre land ville kunne være til nytte for noen av oss; en mulighet til råderett for noen, en mulighet til barmhjertighet for andre. Men det ville samtidig - uunngåelig - sende et signal fra storsamfunnet om at noen blant oss er unnværlige, at noen tilstander kan gjøre selve livet uverdig, at vi noen ganger kan tillate oss å gi opp forsøket på hjelpe de svakeste blant oss. Vi som står bak denne boken, er ikke blinde for argumentene om at dødshjelp kan være noe nordiske borgere kan ønske seg. Men vi mener at et samfunn som tillater dødshjelp, innfører det i lovs form, og på den måten normaliserer dette at syke, svake og sårbare kan bli hjulpet til å dø - det vil være et samfunn som bryter med grunnleggende nordiske verdier.

Enkeltmennesker kan oppleve håpløshet og uverdighet, og få tanker om at det ville være bedre å være død. Som samfunn - som nordisk samfunn - er vår modell å være de som møter motløshet med en enda større 
innsats for å se hvor vi kan hjelpe, hva vi selv kan ofre for å støtte den som vakler. Det er når individet er i ferd med å gi opp, at samfunnet må vise sin styrke. Vi har ikke lov til å gi opp.

\author{
Oslo, april 2020 \\ Morten Andreas Horn \\ Daniel Joachim Heggheim Kleiven \\ Morten Magelssen
}

\title{
Ordforklaringer
}

avhengighet: beroende (S), afhængighed (D)

begrunner: motiverar $(S)$, berettiger $(D)$

borgere: medborgare $(S)$

dannet: bildade (S)

dybden: djupet (S)

egnet: lämplig (S), passende (D)

enkeltmennesker: enskilda personer (S)

ethvert: varje $(S)$

felles: gemensamt (S)

fellesskap: samhälle (S), samfund (D)

forrang: företräde (S)

i grove trekk: i stort sett (S), nogenlunde (D)

innad: inom (S), inden for (D)

jus: rättsvetenskap (S), jura (D)

overfladiskheten: ytan (S)

pårørende: anhöriga (S)

selvmordstruede: självmordsbenägna (S), selvmordstruede (D)

skjulte: dolda (S)

udekkede: otillfredsställda (S), uopfyldte (D)

unnværlig: umbärlig (S), undværlig (D)

å yte: att ge (S) 

Del I

Dødshjelp i Norden 



\title{
KAPITTEL 1
}

\section{Fem spor i dødshjelpsdebatten}

\author{
Morten A. Horn \\ Oslo universitetssykehus \\ Morten Magelssen \\ Senter for medisinsk etikk, Universitetet i Oslo
}

\begin{abstract}
The assisted dying debate in the public square often involves talking past one another. Participants talk about what is important to themselves, without necessarily considering the other party's arguments. Why is this so? We believe it is partly because the assisted dying debate actually consists of several more or less distinct "tracks", all of which are important, but where not all are equally important to all participants. In this chapter, we outline the five main tracks of the assisted dying debate and show what characterises them and how they are expressed in the public debate.
\end{abstract}

Keywords: assisted dying, euthanasia, legalisation of assisted dying, public debate

Dødshjelp er et tilbakevendende diskusjonstema i de nordiske landene. Som deltakere i den norske debatten gjennom ti år har vi ofte følt på det som trolig frustrerer mange av aktørene i debatten: Den blir ofte uoversiktlig og lite produktiv. Dødshjelp er i seg selv et emosjonelt og polariserende tema, og et saklig ordskifte hemmes av at selve terminologien er omstridt. Verdiladede begreper anvendes som selvstendige argumenter for debattantens ståsted (se kap. 2). Men debatten blir enda vanskeligere fordi ulike aktører ofte diskuterer hvert sitt tema. Vår erfaring har vist oss at det særlig er fem hovedområder, eller spor, som dødshjelpsdebatten gjerne følger (se Ramme 1). I dette kapitlet vil vi identifisere disse sporene og illustrere dem med eksempler. Målet er å bevisstgjøre aktørene i debatten slik at de i større grad kan diskutere samme aspekter av dødshjelp samtidig. Ett formål med rammeverket er å hjelpe debattantene M. A. Horn, D. J. H. Kleiven \& M. Magelssen (Red.), Dødshjelp i Norden? Etikk, klinikk og politikk (Kap. 1, s. 21-34). Oslo: Cappelen Damm Akademisk. https://doi.org/10.23865/noasp.96.ch1.

Lisens: CC BY 4.0. 
til å sortere i argumentene. Hvis man plasserer argumentene langs de ulike sporene, blir det kanskje lettere å forstå hvorfor to debattanter kan være enige om mye, men likevel rykende uenige om andre ting, og lande på hver sin konklusjon. Kanskje blir det også lettere å forstå hvordan to debattanter kan komme fra hvert sitt ståsted, og likevel konkludere likt.

Vår fremgangsmåte har tre steg:

1) Basert på vår erfaring med deltakelse i og observasjon av den norske dødshjelpsdebatten identifiserer vi fem grupper med tema. Gruppene - eller «sporene», som vi kaller dem - skal i minst mulig grad være overlappende. De bør være i sum være mest mulig uttømmende, det vil si at alle eller de fleste temaer i dødshjelpsdebatten som kan hevdes å være viktige, fanges opp. Utgangspunktet var en artikkel én av oss skrev for noen år siden (Horn, 2013); ${ }^{1}$ dette rammeverket har vi så videreutviklet sammen.

2) For hvert spor nevner vi helt kort de temaene som etter vårt syn er spesielt viktige, enten fordi de har stor normativ betydning for hvor man lander i dødshjelpsspørsmålet, fordi de ofte misforstås, eller fordi de etter vår oppfatning ikke har fått tilstrekkelig oppmerksomhet i debatten.

3) Rammeverket som de fem sporene utgjør, valideres deretter empirisk ved en enkel analyse av det som er skrevet om dødshjelp i norske medier i 2018. Til sist reflekterer vi over hvilken nytte rammeverket kan ha. ${ }^{2}$

Ramme 1. Fem spor i dødshjelpsdebatten

1. Grunnleggende spørsmål om liv og død

2. Retten til å bestemme over egen død, og selvbestemmelsens grenser

3. Hjelperens rolle i dødshjelp

4. Helsefaglige premisser i dødshjelpsdebatten

5. Debatten om legalisering, og andre lands erfaringer

1 Vi er også kjent med Norunn Kosbergs seksdeling av dødshjelpsdebatten (https://fritanke.no/ nyheter/debatten-om-aktiv-dodshjelp-handler-om-seks-ulike-tema/19.10770). Den er naturlig nok delvis overlappende med vår inndeling, men vår favner viktige aspekter, for eksempel i spor $10 g$, som etter vår vurdering ikke dekkes av Kosbergs inndeling.

2 De øvrige kapitlene i denne boka følger ikke inndelingen i de fem sporene strengt, men er delt inn i seksjonene «Etikk», «Klinikk» og «Politikk». I gjennomgangen av spørsmålene som hører til hvert av de fem sporene, refererer vi til kapitler der disse spørsmålene gis særlig oppmerksomhet. 


\section{Spor 1: Grunnleggende spørsmål om liv og død}

Dødshjelpsdebatten kan handle om autonomi, om lidelse som ikke kan lindres, eller om utfordringer med å lovregulere dødshjelp. Men for mange aktører er et kjernespørsmål dette: Er det overhodet etisk akseptabelt at noen, enten det er helsepersonell eller andre, hjelper en annen person, enten det er en lidende pasient eller et friskt menneske, med å ta sitt eget liv?

For noen er svaret på dette spørsmålet at «det kommer an på». Det kan avhenge av egenskaper ved den som ønsker å dø, av kvalifikasjonene til den som skal hjelpe, av prosedyrene rundt selve handlingen eller av måten samfunnet håndterer eventuelle konsekvenser av dødshjelp praktisert $\mathrm{i}$ helsetjenesten på. Men for andre er alt dette av underordnet betydning: De er opptatt av om det i det hele tatt kan være akseptabelt at noen hjelper andre med å $\mathrm{d} \varnothing$.

Det gir mening å behandle dette spørsmålet først, for hvis svaret skulle være «nei - det er alltid uakseptabelt», er svaret på hva man bør mene om dødshjelp, dermed gitt. Og det samme gjelder kanskje også for et nært beslektet spørsmål, nemlig hvorvidt selvmord - med eller uten andres hjelp - kan være etisk akseptabelt.

Finnes det moralske absolutter, det vil si unntaksløse moralske (for-) bud, slik som et forbud mot å ta menneskeliv? I religiøse, naturrettslige og pliktetiske rammeverk kan det gjøre det (Finnis, 1991). Også uavhengig av slike etiske systemer vil mange mene at det å ta et annet menneskes liv, er å krysse en viktig grense. «Ærefrykt for livet» er en holdning også mange ikke-religiøse vil slutte seg til. Andre igjen vil medgi at selv om det er noe spesielt ved å ta et menneskes liv, betyr ikke det at det aldri kan være rett. Rettferdig krig og selvforsvar kan fremmes som moteksempler. Er dødshjelp også et slikt moteksempel, og altså en situasjon der det å ta liv kan være rettferdiggjort?

Andre grunnleggende spørsmål om liv og død som diskuteres i dette sporet, er blant annet: Hva er døden? Hvilken tilstand bringer den oss over til? Medfører den eksistensens totale opphør, eller venter en positiv eller negativ - tilværelse? Hva, mer eksakt, gjør døden typisk til noe sterkt negativt, og hvordan forholder dette seg for personer som vurderer dødshjelp? (Moen \& Sterri, 2019). 
Sentralt står også spørsmål om livskvalitet. Hva er det, kan det måles, og hvem kan bedømme det? Kan tilværelsen være så preget av lidelse at livet så å si har negativ verdi og ikke er verdt å leve? Et typisk trekk ved vanlige folks forestillinger om dødshjelp, slik de kommer til uttrykk i folkemøter, leserinnlegg og nett-kommentarer, er at man ser for seg dødshjelp som særlig aktuelt for pasienter med alvorlig kroppslig sykdom; typisk de med enten store smerter eller store funksjonstap og dermed betydelige pleie- og omsorgsbehov (Magelssen et al., 2016). En rekke av dødshjelpssakene som omtales i mediene, handler om personer med alvorlig kroppslig sykdom. Mange uttrykker spontant stor forståelse for at nettopp disse menneskene har et ønske om å dø, og bør få hjelp til å gjennomføre det. Spørsmålet er hvilke faktorer som gjør at nettopp disse menneskene peker seg ut. Handler det om at vi anser visse tilstander som så negative at de i seg selv kan gjøre livet mindre verdt enn døden?

Disse spørsmålene kom for eksempel til uttrykk i diskusjonen rundt Jojo Moyes' filmatiserte bok Me Before You (Et helt halvt år). Boka og filmen vekket sterke reaksjoner fra funksjonshemmede som lever med samme type ryggmargskade som hovedpersonen Will. Kritikken mot Moyes' framstilling gjaldt ikke primært hennes sympati for dødshjelp som fenomen, men hennes framstilling av Wills liv som «ikke verdt å leve» etter ulykken som ga ham skaden; selv ikke da han hadde kommet seg gjennom den akutte krisereaksjonen, og selv ikke da han hadde funnet kjærligheten med Lou (Horn, 2016b).

Som en digresjon vil vi peke på at spørsmålene om livskvalitet - som kan være høyst relevante og opplysende å drøfte - har forbindelseslinjer til en tematikk som er nesten urørbar i dødshjelpsdebatten: Erfaringen med nazistenes utryddelse av personer med genetiske sykdommer, psykisk utviklingshemning og andre tilstander som ble bedømt som «ikke-leveverdige liv». Det er en generell erfaring at dødshjelpsdebatter som trekker inn nazistenes eutanasi-program $\mathrm{T}_{4}$, typisk sporer av. Tilhengere av legalisering av dødshjelp peker på selvbestemmelsen som den viktigste av flere faktorer som gjør at nazistenes praksis ikke har noe med dagens dødshjelp å gjøre, og derfor er uten relevans for vår debatt. Noen kritikere mener likevel at det ligger lærdom for oss i at 
T4-programmet bygget på et grunnsyn om at visse liv ikke var verdt å leve.

\section{Spor 2: Retten til å bestemme over egen død, og selvbestemmelsens grenser}

I den vestlige verden står menneskets rett til styring over eget livsløp helt sentralt. Autonomi - selvbestemmelse - har blitt en stadig viktigere verdi også i helsetjenesten, noe som kan spores i økte formelle pasientrettigheter. Retten til å avvise medisinsk behandling, også potensielt livsforlengende behandling, er bredt anerkjent i Nord-Europa.

Som et ledd i utviklingen i retning mer selvbestemmelse og kontroll kommer også ønsket om kontroll over døden: Mange vil selv bestemme når og hvordan døden skal inntreffe. De ønsker å få dø i en situasjon der man er forberedt på dødens komme, og gjerne omgitt av sine kjære. I tillegg til kontroll er opplevelse av verdighet og det å unngå lidelse viktige begrunnelser for å be om dødshjelp.

Mange anser det å bestemme over egen død som en moralsk rettighet, på linje med for eksempel kvinners rett til å bestemme over egen kropp i abortspørsmålet. Noen mener det burde være en menneskerett, eller at det allerede er en menneskerett. Den europeiske menneskerettsdomstolen har ikke uttalt seg bastant om spørsmålet, men landet i Diane Pretty-saken fra 2002 på at retten til å ta sitt eget liv uten samfunnets inngripen, med henvisning til artikkel 8 i Den europeiske menneskerettskonvensjon, måtte underordnes artikkel 2 og retten til liv. I Canada derimot, fant høyesterett i 2015 et forbud mot dødshjelp grunnlovsstridig, med henvisning til borgerrettighetene i det kanadiske charteret.

For mange som ytrer seg om dødshjelp i offentligheten, er spørsmålet om selvråderett helt sentralt, og det kan ofte oppsummeres slik: «Det er mitt liv og min død.» I dette sporet diskuteres også hvilke begrensninger selvråderetten ved livets slutt eventuelt bør ha. Et relevant rammeverk her er kontrasten mellom to politisk-ideologiske innstillinger til moralsk uenighet: På den ene siden vil politisk liberalisme (f.eks. Rawls, 1996) tilsi at individet skal ha størst mulig rom for egne valg, og at staten skal trekke 
seg tilbake og la borgerne avgjøre omstridte etiske spørsmål selv. Sondre Hansmark, leder i ungdomspartiet Unge Venstre, skrev for eksempel: «Den private autonomien skal strekke seg så langt som mulig, så fremt den ikke begrenser andre menneskers frihet i samme slengen (...) Å legalisere eutanasi, selv med visse begrensninger (...), vil bidra til å styrke den personlige autonomien» (Hansmark, 2018). På den andre siden vil kommunitarismen (f.eks. Sandel, 1998) peke på at siden mennesker lever sine liv i fellesskap, får autonome handlinger nesten alltid konsekvenser også for andre enn den handlende. Bekymringen er særlig at legalisering av dødshjelp sender et negativt signal til personer som kan oppleve at de ligger andre til byrde (se kap. 5), eller legger press på dem.

Hvis adgang til dødshjelp begrunnes med selvbestemmelse, kan det bli vanskelig å begrunne prinsipielt de grensedragningene som avgjør hvem som kvalifiserer til dødshjelp, og hvem som skal avvises (se kap. 7). En konsekvens av dette kan være at samfunnets tradisjonelle holdning til selvmordstruede individer må tas opp til ny vurdering. Hvordan skille mellom personer som ønsker å dø og bør få dødshjelp, og personer som ønsker å dø, men som samfunnet snarere skal hindre i dette, til og med ved bruk av tvang? (Se også kap. 11.) Selv om selvmord er avkriminalisert, har man i Norge i dag ingen ubetinget «rett» til å avslutte sitt liv gjennom selvmord (Husabø, 1994). Man blir tvert imot forhindret i det, så fremt det er mulig.

\section{Spor 3: Hjelperens rolle i dødshjelp}

Dødshjelp skiller seg fra «vanlig» selvmord ved at personen får hjelp av en annen person til å dø. Dermed må en etisk vurdering av hjelperens valg også stå sentralt når vi vurderer om dødshjelp er rett eller galt. Det er verdt å merke seg at eksisterende lover ikke gir pasienter noen rett til dødshjelp, derimot innvilger de straffritak til leger som utfører dødshjelp innenfor regelverket. Siden dødshjelperen som regel er en lege, er det naturlig at leger engasjerer seg i debatten. Det synes imidlertid som om noen opplever denne fokuseringen på hjelperen som en avsporing, fordi man selv ser på dødshjelpsspørsmålet gjennom pasientens øyne, som i spor 2. «Hvem skal bestemme over mitt liv - er det legene/samfunnet eller er det jeg selv?» blir det spurt retorisk (Ingul, 2018). Men idet en annen aktør involveres, noe 
som nødvendigvis skjer ved dødshjelp, blir argumenter som taler for og mot denne aktørens medvirkning, med én gang relevante.

Et viktig spørsmål er derfor hvilken forskjell det utgjør at dødshjelperen er en lege eller annet helsepersonell. Legers profesjonsetikk har tradisjonelt avvist dødshjelp, gjennom et forbud som kan spores tilbake til den hippokratiske legeeden. Bør dette være til hinder for at profesjonsetikken «nytolkes» til også å innlemme det å utføre dødshjelp? Hvilke grunner kan tale for å opprettholde det profesjonsetiske forbudet? Hvordan kan legerollen og lege-pasient-forholdet påvirkes av at legen har anledning til å utføre dødshjelp? (Se kap. 9.) Dette er viktige spørsmål som diskuteres i dette sporet.

Hvis dødshjelp blir tillatt, hva da med leger som nekter å ha befatning med dette? Bør det være en reservasjonsrett mot å utføre dødshjelp, og hvis ja, bør den også omfatte henvisning til villige kolleger? (Horn, 2016a; Magelssen, 2012; Myskja \& Magelssen, 2018.) I norsk ordskifte hevdes det ofte som en selvfølge at ingen leger skal tvinges til å yte dødshjelp. Men erfaringen fra Canada viser at det å innføre dødshjelp i neste omgang vil sette samvittighetsfriheten under press. Hvis dødshjelp blir en formell pasientrettighet, eller oppfattes som en de facto rettighet, vil helsetjenesten også få et ansvar for at den oppfylles. En reservasjonsadgang kan være vanskelig å forene med pasienters rett til dødshjelp, kanskje særlig i spredt bebygde land som Norge, Sverige og Finland. Individets rett til styring over egen død (jf. spor 2) kan komme i konflikt med hjelperens egen autonomi og rett til å følge sin samvittighet og profesjonsetikk. I Sverige og Finland er det ikke tradisjon for reservasjonsrett i helsetjenesten.

Langs dette sporet kan man også diskutere hvilke kvalifikasjoner dødshjelperen bør ha. Det vanligste er å foreslå at leger skal yte dødshjelpen, og man kan tenke seg kriterier for hvilke leger som skal være kvalifisert. Eksempelvis, hvilken relasjon bør legen ha til pasienten? Bør det være fastlegen, som kanskje har kjent pasienten i mange år, eller bør det snarere være en spesialisert dødshjelpslege? Hvilken utdanning må legen ha? Må en søknad om dødshjelp forhåndsvurderes i en nemnd? Det er også mulig å se for seg andre yrkesgrupper involvert i dødshjelp, som i Canada, der spesialsykepleiere kan beslutte og utføre dødshjelp helt uten legers involvering. Det diskuteres også hvorvidt dødshjelp bør holdes utenfor helsetjenesten, som i Carl Elliotts «filosof-assisterte selvmord» (1996). 


\section{Spor 4: Helsefaglige premisser i dødshjelpsdebatten}

Hvis en debatt skal bli god, må den bygge på et presist faktagrunnlag. Det gjelder for ethvert medisinsk-etisk spørsmål. Helsefaglige og andre empiriske premisser er derfor av største betydning for dødshjelpsdebatten. Men iblant er det ikke opplagt hva som er fakta, og ofte vil det være omstridt hvordan empirien skal tolkes, og hvilken betydning den bør få i den normative debatten om dødshjelp. Dette sporet er altså primært et faglig område, der det medisinske evidensgrunnlaget blir avgjørende. Men dels er også faglige «sannheter» mulige å utfordre, både av kritiske røster blant fagfolk selv og av legfolk som ser ting annerledes enn fagfolkene gjør.

Blant de viktige spørsmålene i dette sporet er: Hvordan skal dødshjelp defineres? (Se kap. 2.) Foregår det mye dødshjelp i det skjulte i dag, til tross for at det er ulovlig? Er avslutning av livsforlengende behandling (behandlingsbegrensning) langt på vei det samme som dødshjelp? (Se kap. 2.) Hva kan lindrende behandling utrette, og finnes det pasienter som ikke kan oppnå adekvat lindring? (Se kap. 10.) Kan medikamentell lindrende behandling med opioider (smertestillende) og benzodiazepiner (angstdempende) forårsake pasientens død? Er lindrende sedering (se kap. 10) egentlig en fordekt dødshjelp?

\section{Spor 5: Debatten om legalisering, og andre lands erfaringer}

Hvis dødshjelp skal legaliseres i de nordiske landene, er det ikke tilstrekkelig å diskutere langs de fire foregående sporene. Før eller senere blir det nødvendig å diskutere hvordan en dødshjelpslov konkret bør utformes.

I spørreundersøkelser er det et klart flertall som mener at dødshjelp kan være riktig i spesielle situasjoner. De fleste synes å mene at det ikke bør være «fritt fram»; mange avviser for eksempel dødshjelp ved psykiske lidelser. Det er derfor et behov for å avgrense - på en måte som er entydig (gir klare føringer for alle involverte parter, inkludert domstolene), 
rettferdig (alle i relevant lik situasjon får samme tilgang til dødshjelp) og forsvarlig (hindrer misbruk og utglidning; se kap. 15). Hvis dødshjelp bør legaliseres, hvordan skulle vi helt konkret gjøre det?

I dette sporet må vi ta stilling til kompliserte spørsmål - juridiske, lovtekniske og praktiske. Dessuten blir helsefaglige premisser fra de foregående sporene relevante. Er det eksempelvis mulig for helsepersonell å bedømme om en pasient opplever «uutholdelig lidelse»? Svaret vil få betydning for hvorvidt et slikt lidelseskriterium kan benyttes i en dødshjelpslov. Det grunnleggende etiske spørsmålet fra spor 1 om hvorvidt dødshjelp i prinsippet kan være akseptabelt, er ikke viktig for selve debatten om hvordan dødshjelp kan legaliseres, fordi den har som sitt utgangspunkt at dødshjelp kan være riktig i hvert fall i noen situasjoner. Spørsmålet her er om man kan klare å avgrense dette på en god måte i lovs form.

Til dette sporet hører også spørsmålet om hva meningsmålinger om dødshjelp viser, og hvordan disse kan fortolkes (se kap. 3). Videre er spørsmålet om hva som vil være konsekvensene av en eventuell legalisering, viktig her. Vil en dødshjelpslov medføre risiko for misbruk, for skråplanseffekter, verdiglidning eller en gradvis «normalisering» av dødshjelp? Erfaringer fra land som har legalisert dødshjelp, vil være vesentlige i denne analysen (se kap. 13).

\section{Holder offentlig debatt seg til de fem sporene?}

For å undersøke om rammeverket med de fem sporene virkelig gir et treffende bilde av offentlig debatt om dødshjelp, gjennomførte én av oss (MM) en enkel analyse av én årgang av dødshjelpsdebatten i norske papiraviser. I databasen Retriever ble det søkt på «dødshjelp», noe som ga 452 treff publisert i 2018. Av disse var 69 unike debatt- eller kommentarartikler som drøftet argumenter om dødshjelp. Tekster som ble publisert tilnærmet identisk i flere aviser, ble bare talt én gang. 33 av tekstene tok tydelig stilling for dødshjelp, $31 \mathrm{mot}$, mens fem var nøytrale eller ikke klart tok stilling. 
Tabell 1. Forekomst av argumenter fra de fem sporene i en årgang tekster om dødshjelp fra norske papiraviser.

\begin{tabular}{|c|l|c|c|}
\hline Spor & Tema & $\begin{array}{c}\text { Forekomst } \mathbf{i} \text { tekster for } \\
\text { dødshjelp }(\mathbf{n}=\mathbf{3 3})\end{array}$ & $\begin{array}{c}\text { Forekomst i tekster } \text { mot } \\
\text { dødshjelp }(\mathbf{n}=\mathbf{3 1})\end{array}$ \\
\hline 1 & Liv og død & 6 & 16 \\
\hline 2 & Selvbestemmelse & 20 & 16 \\
\hline 3 & Hjelperens rolle & 1 & 7 \\
\hline 4 & Helsefaglige premisser & 19 & 11 \\
\hline 5 & Legalisering og andre land & 12 & 21 \\
\hline
\end{tabular}

Tekstene ble skjønnsmessig kategorisert ut fra hvilke argumenter de tok opp (Tabell 1). ${ }^{3}$ Tekstene som argumenterte for dødshjelp, trakk særlig frem argumenter om selvbestemmelse samt helsefaglige premisser som at mange pasienter har lidelse som ikke kan lindres godt nok. Tekstene som argumenterte mot dødshjelp, la ofte vekt på problemer med andre lands dødshjelpspraksis eller vanskene med å konstruere en god dødshjelpslov, problemer med at selvbestemmelsen skal være reell eller vanskelig lar seg avgrense, og poenger om livets ukrenkelighet. Ett funn var at debattantene sjelden la vekt på argumenter som talte mot deres eget syn, annet enn ved å presentere dem helt kort - for så å argumentere mot dem. Debatten kan derfor karakteriseres som polarisert.

I gjennomgangen fant vi ingen argumenter som etter vår vurdering ikke greit lot seg innpasse i et eller flere av de fem sporene. Ut fra dette synes det som om rammeverket med de fem sporene gir et treffende bilde av offentlig dødshjelpsdebatt og temaene som står sentralt der.

De 33 tekstene for dødshjelp var skrevet av 18 ulike forfattere (noen hadde flere enn én forfatter). Fem tekster var skrevet av politikere, fra Fremskrittspartiets Ungdom, Grønn Ungdom og Unge Venstre. Halvparten av tekstene (17) var skrevet av nåværende eller tidligere representanter for interesseorganisasjonen Foreningen Retten til en verdig død.

De 31 tekstene mot dødshjelp hadde 26 ulike forfattere, og ti av tekstene var skrevet av politikere (fra KrF, Høyre og deres ungdomspartier). Åtte

3 Kategoriseringen var i noen tilfeller krevende og kunne gjøres på flere måter. Derfor bør det ikke legges for mye vekt på fordelingen mellom kategoriene. 
av tekstene var signert representanter for interesseorganisasjonen Menneskeverd. Tre var skrevet av dette kapitlets forfattere.

\section{Fem spor i dødshjelpsdebatten - hva er nytten av rammeverket?}

Vi har skissert fem spor i dødshjelpsdebatten, fem hovedkategorier som temaene i denne debatten lar seg plassere i. Alle disse er viktige og interessante å drøfte, selv om ulike aktører kan være mer eller mindre opptatt av enkelte av dem. Eksempelvis kan leger være særlig opptatt av å drøfte hjelperens rolle, som får konsekvenser for deres egen yrkesgruppe (spor 3). Funksjonshemmedes foreninger kan være særlig opptatt av om dødshjelp utsier noe om hva livskvalitet og et leveverdig liv er (spor 1). Helsepersonell og medier har en viktig oppgave i å formidle sannferdig og forståelig informasjon om helsefaglige premisser for dødshjelpsdebatten (spor 4). Religiøst motiverte aktører kan være særlig opptatt av å diskutere menneskeverdet, livets hellighet og den etiske normen om ikke å drepe (spor 1). For borgere flest er kanskje argumentet om råderett over egen død det viktigste (spor 2). Våre politikere, derimot, må etter vårt syn særlig vie seg til legaliseringssporet (spor 5) - det er der de skal gjøre sin innsats. Det er også alt i alt det viktigste sporet i dødshjelpsdebatten vi som samfunn må forholde oss til: Dersom dødshjelp skal gå fra å være forbudt til å bli tillatt, krever det at politikerne finner fram til et lovverk som kan regulere dette på en forsvarlig måte.

Rammeverket viser hvilke spor dødshjelpsdebatten kan forløpe langs, og synliggjør samtidig at det er mulig å ha syn som «trekker i ulik retning» fra spor til spor. En debattant kan på ett spor ha et syn som trekker i retning av at dødshjelp bør bli tillatt, mens hun på et annet spor har en oppfatning som går i motsatt retning. En persons svar langs ett av sporene dikterer ikke vedkommendes svar på de øvrige. Særlig viktig er det å se at en prinsipiell holdning om at borgere må få ha stort rom for selvbestemmelse ved livets slutt (spor 2), ikke nødvendigvis impliserer støtte til legalisering av dødshjelp, selv om det kan trekke i den retningen. For det kan hende at aktuelle modeller for legalisering har avgjørende svakheter som gjør at legalisering likevel ikke er tilrådelig (spor 5). Rammeverket 
viser altså hvordan nyanserte - og kanskje overraskende - konstellasjoner av oppfatninger kan fremkomme og ikke innebærer noen selvmotsigelse. Eksempelvis argumenterer moralteologen Nigel Biggar for at det noen ganger kan være etisk rett å ta liv ved dødshjelp, men mot legalisering - av frykt for skråplanseffekter (Biggar, 2004).

I dødshjelpsdebatten er det ikke uvanlig at man kan være både enig og uenig med sin motdebattant. Selv om utfallet av diskusjonen gjerne presenteres som en skarp dikotomi - «skal dødshjelp være tillatt, ja eller nei?» - er mange av de sentrale poengene slik at både tilhengere og motstandere kan dele dem og oppleve dem som «sine», i varierende grad.

«Spor»-metaforen kan videreføres til å gi debattanter og debattledere noen enkle råd: En god debatt må holde seg på sporet og ikke spore av. Hvilket spor er jeg på nå, og er min motdebattant på samme spor? Kun da vil det fruktbare sammenstøtet(!) mellom argumenter som går i hver sin retning, kunne finne sted. Samtidig må ikke debatten bli ensporet, men ideelt sett forholde seg til samtlige fem spor - bare ikke alle på én gang. For den som skal delta aktivt i dødshjelpsdebatten, kan en slik inndeling i fem spor være nyttig, når man skal velge hvilke diskusjoner man vil begi seg inn på og når. For den som skal styre debatten, kan det også være bra å reflektere over disse sporene, for eksempel i forkant av et folkemøte: Hvilke temaer skal vi ta for oss denne gangen, hvilke instrukser skal vi gi debattantene, for å sikre at man i størst mulig grad diskuterer samme tema og snakker til hverandre, ikke forbi hverandre?

De som analyserer dødshjelpsdebatten, kan også dra nytte av en slik inndeling. Den norske «medieundersøkelsen» fra 2015 stilte spørsmålet enkelt slik: «Hva er din holdning til aktiv dødshjelp? Mener du det er riktig å ha mulighet til å kunne gi aktiv dødshjelp, eller mener du aktiv dødshjelp ikke skal være tillatt?» (Kumano-Ensby \& Lauritzen, 2015). Det er lett å se at et slikt spørsmål rommer elementer som kan plasseres i flere av de sporene vi har identifisert her. Noen av respondentene vil kanskje svare ut fra et generelt syn på om det er riktig eller galt å ta liv eller å la en person begå selvmord (spor 1). Andre vil svare ut fra sine tanker om råderetten over egen $\mathrm{død}$ (spor 2). Andre igjen vil være opptatt av hvem som i så fall skal utføre dødshjelpen, og konsekvensene for dem (spor 3). Noen vil svare ut fra en forestilling om at dødshjelp alt i dag foregår i det 
skjulte, forkledd som lindrende behandling (spor 4). Til tross for en slik palett av motiver og refleksjoner som kan ligge bak respondentenes svar, munner undersøkelsen ut i noe som går mest på sporet om legalisering av dødshjelp (spor 5), samtidig som svaralternativene ikke forteller oss noe som helst om hvordan respondentene eventuelt ser for seg at dødshjelp skulle vært avgrenset, regulert og kontrollert. Dersom meningsmålerne hadde forholdt seg til de fem sporene i dødshjelpsdebatten som vi har skissert her, kunne man tenke seg mer målrettede spørsmål som tester ut befolkningens syn langs disse sporene, og som gir et mye mer nyansert bilde.

\section{Referanser}

Biggar, N. (2004). Aiming to kill. The ethics of suicide and euthanasia. London: Darton, Longman and Todd.

Elliott, C. (1996). Philosopher assisted suicide and euthanasia. BMJ, 313(7064), 1088. Finnis, J. (1991). Moral absolutes. Tradition, revision, and truth. Washington, DC: Catholic University of America Press.

Gaasø, O. M., Rø, K. I., Bringedal, B. \& Magelssen, M. (2019). Legers holdninger til aktiv dødshjelp. Tidsskr nor legeforen, 139(1), 31-35. Hentet fra https://tidsskriftet. no/2019/o1/originalartikkel/legers-holdninger-til-aktiv-dodshjelp

Hansmark, S. (2018, 15. januar). Krever kloke avveininger. Vårt Land.

Horn, M. (2013, 19. april). Fire spor i dødshjelpsdebatten. Fri tanke. Hentet fra https://fritanke.no/fire-spor-i-dodshjelpsdebatten/19.9073

Horn, M. (2016a, 26. mars). Bør retten til å nekte å ta liv inn i grunnloven? Aftenposten.

Horn, M. (2016b, 23. september). Liten toleranse for svakhet. Vårt Land.

Husabø, E. J. (1994). Rett til sjølvvalt livsavslutning? Oslo: Ad Notam Gyldendal. Ingul, O. (2018, 23. juni). Dødshjelp. Trønder-Avisa.

Kumano-Ensby, A. L. \& Lauritzen, F. (2015, 12. mars). Ny undersøkelse overrasker: Hver fjerde lege er for aktiv dødshjelp. NRK.no. Hentet fra https://www.nrk. no/dokumentar/ny-undersokelse-overrasker_-hver-fjerde-lege-er-for-aktivdodshjelp-1.12245367

Magelssen, M. (2012). When should conscientious objection be accepted? Journal of Medical Ethics, 38(1), 18-21.

Magelssen, M., Supphellen, M., Nortvedt, P. \& Materstvedt, L. J. (2016). Attitudes towards assisted dying are influenced by question wording and order: A survey experiment. BMC Medical Ethics, 17. 
Moen, O. M. \& Sterri, A. B. (2019). Aktiv dødshjelp. Etikk ved livets slutt. Oslo:

Cappelen Damm Akademisk.

Myskja, B. \& Magelssen, M. (2018). Conscientious objection to intentional killing:

An argument for toleration. BMC Medical Ethics, 19, 82.

Rawls, J. (1996). Political liberalism. New York: Columbia University Press.

Sandel, M. J. (1998). Liberalism and the limits of justice. Cambridge: Cambridge

University Press.

\section{Ordforklaringer}

bevisstgjøre: uppmärksamma (S), bevidstgøre (D)

borgere: medborgare (S)

borgerrettigheter: civila rättigheter $(\mathrm{S})$, borgerrettigheder (D)

digresjon: utvikning (S), sidespring (D)

formål: syfte $(\mathrm{S})$

forskjell: skillnad (S), forskel (D)

framgangsmåte: förfarande (S), procedure (D)

føringer: riktlinjer (S), retningslinjer (D)

i samme slengen: samtidigt (S, D)

i sum: totalt $(\mathrm{S}, \mathrm{D})$

innvilge: bevilja (S)

måles: mätas (S)

måten: sättet (S), måden (D)

selv ikke: även om inte (S)

selvfølge: skjälvklarhet (S), selvfølgelighed (D)

selvmordstruede:s (S)

skjulte: dolda (S)

skråplan: sluttande plan (S), glidebane (D)

spore av: spåra ur (S), afspore (D)

straffritak: undantag från straff (S), fritagelse fra straf (D)

ståsted: perspektiv (S), utsigtspunkt (D)

unntaksløs: utan undantag (S)

utfordre: utmana (S)

vanskelig: svårt (S), svært (D)

ærefrykt: vördnad (S), ærefrygt (D) 


\title{
KAPITTEL 2
}

\section{Språk og virkelighet $\mathrm{i}$ dødshjelpsdebatten}

\author{
Morten Magelssen \\ Senter for medisinsk etikk, Universitetet i Oslo
}

\begin{abstract}
Language describes reality. It also creates reality and perceptions. This is particularly evident in the assisted dying debate; there is a "battle for concepts" where both sides have their preferred words. But fruitful ethical debates require concepts and definitions that the debaters can agree on. This chapter therefore proposes a set of concepts and definitions for the Nordic assisted dying debate. Good concepts are concrete and precise, with simple and unambiguous language free from unnecessary use of imported terms; they have concise and normatively neutral definitions, and they are preferably already familiar to and in use by the public. The last part of the chapter asks whether the way we have linguistically drawn the most important distinction in the field of assisted dying - between euthanasia on the one hand and treatment-limiting decisions on the other - points to a real difference that is also ethically relevant. It is argued that the answer is yes, and that the healthcare provider's intention is an ethically relevant difference: In euthanasia, the patient's death is intended, while in treatment-limiting decisions the intentions are typically of quite another nature.
\end{abstract}

Keywords: assisted dying, euthanasia, intention, non-treatment decisions, treatment-limiting decisions

Krevende etiske debatter blir enda mer krevende dersom vi er uenige om hva det er vi debatterer, og om hvilke navn vi skal gi det. I dette kapitlet vil jeg argumentere for et sett begreper og tilhørende definisjoner som er ment å karakterisere nøkkelkonseptene i dødshjelpsdebatten (Ramme 1).

Sitering av denne artikkelen: Magelssen, M. (2020). Språk og virkelighet i dødshjelpsdebatten. I M. A. Horn, D. J. H. Kleiven \& M. Magelssen (Red.), Dødshjelp i Norden? Etikk, klinikk og politikk (Kap. 2, s. 35-49). Oslo: Cappelen Damm Akademisk. https://doi.org/10.23865/noasp.96.ch2.

Lisens: CC BY 4.0. 
Ramme 1. Foreslåtte begreper og definisjoner til bruk i dødshjelpsdebatten

Eutanasi: At helsepersonell forårsaker personens død med hensikt, ved å injisere dødbringende medikamenter, på personens forespørsel.

Assistert selvmord: Å bidra til å forårsake personens død med hensikt, ved å bringe til veie dødbringende medikamenter som personen kan innta selv, på personens forespørsel.

Dødshjelp: En samlebetegnelse på eutanasi og assistert selvmord.

Medisinsk drap uten forespørsel: At helsepersonell forårsaker personens død med hensikt, ved å administrere dødbringende medikamenter, uten personens forespørsel.

Behandlingsbegrensning (synonym: begrensning av livsforlengende behandling): Å avslutte, eller ikke starte, potensielt livsforlengende behandling hos en alvorlig syk pasient.

\section{Kampen om begrepene}

I mange bioetiske stridsspørsmål foregår det en kamp om hvilke begreper og definisjoner som skal brukes. Begge sider kan ha interesse av å fremme sine foretrukne begreper. Hvis folk begynner å tenke om temaet i de termer du ønsker, kan det øke sjansene for at de kommer til samme konklusjon som deg. Begreper kan være normativt ladet og lede deg til å se saken på en spesifikk måte. Et eksempel fra et annet stridsspørsmål i medisinsk etikk: Det er antagelig lettere å akseptere «omskjæring» enn «kjønnslemlestelse» (engelsk: «circumcision»vs. «genital mutilation»).

På dødshjelpsfeltet er denne «kampen om begrepene» enda tydeligere enn i kanskje noen annen bioetisk debatt. Eksempler kan hentes fra hele verden. Den amerikanske delstaten Oregons dødshjelpslov heter «Death with Dignity Act». Uavhengig av hva man mener om legalisering av dødshjelp, er det klart at dette navnet er valgt for å fremstille dødshjelpshandlingen i et positivt lys. Det er en eufemisme, en skjønnmalende omskrivning. Da den fremste pro-dødshjelps-organisasjonen i USA byttet navn, falt valget på «Compassion \& Choices». I kanadisk lovverk og debatt omtales dødshjelp som «medical aid in dying». Men formuleringen «aid in dying» («hjelp i døden», «hjelp til å dø») underslår at det kun er snakk om en helt spesifikk hjelp; ved eutanasi forårsaker helsepersonellet døden med en dødbringende injeksjon. Begrepet «selvbestemt livsavslutning» har blitt brukt i den norske debatten. Det alluderer til den viktige og positivt ladede verdien autonomi, og det låner autoritet av 
«selvbestemt abort», som har bred oppslutning. Selv begrepet «eutanasi» er positivt ladet, da det kommer av det greske «eu thanatos» - «god død».

Selvsagt forsøker også dødshjelpsmotstanderne å spille på retoriske strenger. I den norske debatten ble begrepet «aktiv livshjelp» lansert som en betegnelse på god og holistisk lindrende behandling, og som det etisk foretrukne alternativet til aktiv dødshjelp. Dødshjelpsmotstandere foretrekker gjerne definisjoner som viser til «drap» eller «selvmord», og noen dødshjelpstilhengere anerkjenner at dette er treffende betegnelser (Moen \& Sterri, 2019). Andre tilhengere vil derimot avvise at dødshjelp innebærer selvmord, drap eller å ta liv: «... ved aktiv dødshjelp tar du ikke liv, du forkorter dødsprosessen», het det for eksempel i en kronikk (Staff-Poulsen, 2019).

I en studie som undertegnede hadde hovedansvaret for, undersøkte vi empirisk en effekt som alle kjenner til: Måten et tema presenteres på, påvirker hvordan folk oppfatter og tar stilling til det (Magelssen et al., 2016). Et utvalg nordmenn fikk ett av to ulike spørsmålssett med påstander om legalisering av dødshjelp som de skulle ta stilling til. Det ene settet var forsøksvis nøytralt formulert, mens det andre (som gjorde bruk av faktiske formuleringer fra tidligere spørreundersøkelser) hadde elementer som vi trodde ville øke den graden av støtte til legalisering som respondenten ga uttrykk for. Således spurte vi for eksempel henholdsvis om «legeassistert selvmord bør tillates for personer som har en dødelig sykdom med kort forventet levetid», og om «En pasient er døende med store smerter. Hvor enig eller uenig er du i at en lege, etter grundig overveielse, da skal ha lov til å skrive ut en dødelig dose medisin som pasienten selv kan velge å ta for å unngå store lidelser, dersom pasienten selv ber om det?». Mens $73 \%$ var enig i første påstand, sa $78 \%$ seg enig i den andre. Gjennomgående var det moderate, men betydningsfulle, effekter av å vri fremstillingen i positiv versus mer nøytral retning.

\section{Enhetlig begrepsbruk og nøytrale definisjoner Behovet for enhetlig begrepsbruk}

Selv om debattanter selvsagt må få fremstille sakens tema på den måten og med de argumenter de foretrekker, er det åpenbart en fordel at alle i 
størst mulig grad bruker de samme begreper og definisjoner. Debatten blir mer presis av det, og misforståelser kan unngås. Trolig vil det spesielt være nyttig for folk som ikke selv er grundig innvidd i temaet når de skal følge og forstå debatten.

\section{Kriterier for gode begreper og definisjoner}

Jeg vil kort argumentere for fem egenskaper ved, eller kriterier for, gode begreper og definisjoner i dødshjelpsdebatten (Ramme 2).

Ramme 2. Kriterier for gode begreper og definisjoner
1. Konkrete og presist beskrivende
2. Enkle og utvetydige, uten fremmedord
3. Allerede kjente og i bruk
4. Kortfattede
5. Normativt nøytrale

Definisjoner i dødshjelpsdebatten må være konkrete og presist beskrivende, ved at de for eksempel faktisk peker ut dødshjelpshandlingen og det som skiller den fra andre handlinger som faller utenom definisjonen. Noen definisjoner har det problemet at de ikke klart skiller ut dødshjelp fra behandlingsbegrensning. Selv om man kan mene at det ikke er moralsk relevante forskjeller på dødshjelp og behandlingsbegrensning (se kapitlets siste del), er det ingen tvil om at det klinisk sett er forskjellige handlinger. Slike problemer kan oppstå når definisjoner benytter eufemismer og er vage i beskrivelsene.

Definisjonene bør være enkle og utvetydige, helst uten bruk av fremmedord, i hvert fall fremmedord som er ukjente for folk flest. Når det er mulig, bør begrepene være slike som allerede er kjent og i bruk. I mitt eget forslag til terminologi har jeg lagt stor vekt på dette, jeg har i det lengste forsøkt ikke å introdusere nye begreper. Begrepene bør være kortfattede, men samtidig inneholde alle de elementer som er sentrale for fenomenet, og som skiller det fra beslektede praksiser. 
Til slutt bør begreper og definisjoner være normativt nøytrale. Det er kanskje her de største fristelsene for debattantene oppstår. Som beskrevet ovenfor er det utbredt at ikke-nøytrale ord smugles inn.

\section{Argumentasjon for de foreslåtte begreper og definisjoner i lys av kriteriene}

Det første grunnbegrepet jeg tar for meg og argumenterer for, er eutanasi. Allerede her kan det se ut til at jeg bryter med et av mine kriterier (nr. 2). Eutanasi er definitivt et fremmedord, men det er trolig et ord som veldig mange både i og utenfor Norden kjenner til og forbinder med dødshjelpsfeltet, og dette er et sterkt argument for å bruke det (kriterium 3). Som beskrevet over er det normativt ladet, men dette er noe kun de greskkyndige fanger opp. Det at «eutanasi» i lang tid har vært brukt av både tilhengere og motstandere av legalisering, taler imot at det er et problem i praksis at begrepet er ladet.

Eutanasi definerer jeg som «at helsepersonell forårsaker personens død med hensikt, ved å injisere dødbringende medikamenter, på personens forespørsel». La oss se på de fem komponentene i denne definisjonen: (1) Det har vært vanlig å knytte eutanasi til leger spesifikt, men i den kanadiske dødshjelpsloven er «nurse practitioners» (spesialsykepleiere med utvidet ansvarsområde) også tillagt myndigheten til å utføre eutanasi. Derfor er det grunn til å la definisjonen vise til helsepersonell uten å spesifisere nærmere. (2) Neste komponent er «forårsake personens død». I definisjonen til European Association for Palliative Care (Materstvedt et al., 2003) brukes ordet «killing» om dette, og det presiseres at ordet brukes i en teknisk - det vil si rent beskrivende og ikke-normativ - forstand. Tilsvarende brukes «drap» i noen norske definisjoner (Magelssen et al., 2016; Gaasø et al., 2019). Problemet er at selv om det stipuleres at «drap» skal være en normativt nøytral betegnelse, vil det neppe oppfattes slik i befolkningen, ettersom «drap» selvsagt har en negativ klang i dagligtalen. Min vurdering er at «avlive» og «ta livet av» støter på samme problem: Mange vil oppfatte disse betegnelsene som negativt ladet. «Forårsake personens død» er konkret, presist og utvetydig, og er en beskrivelse både 
tilhengere og motstandere av dødshjelp bør kunne akseptere som normativt nøytral. Til gjengjeld blir definisjonen noe mer ordrik.

(3) Videre er det viktig å ha med leddet «med hensikt», for å skille eutanasi fra situasjoner der pasienter dør utilsiktet, for eksempel etter sjeldne medikamentbivirkninger. «Hensikt» er her ment synonymt med (fremmedordet) «intensjon». (4) Eutanasi innebærer injeksjon av dødbringende medikamenter, dette er måten døden frembringes på i alle jurisdiksjoner som åpner for eutanasi. Ordet «person» er valgt fremfor «pasient», fordi det kan tenkes situasjoner der personen som ber om eutanasi, ikke er i et etablert lege-pasient-forhold, og der det ikke er medisinske tilstander som motiverer forespørselen.

(5) Til sist er det viktig, og helt i tråd med hvordan eutanasi praktiseres der det er tillatt, at eutanasi kun skjer etter personens forespørsel. Implisitt i dette ligger at forespørselen er frivillig og at den er kompetent, det vil si at personen er beslutnings-/samtykkekompetent (Pedersen \& Aarre, 2017). Hvis personen får den dødbringende injeksjonen uten at vedkommende har forespurt dette, dreier det seg ikke om eutanasi. Noen skribenter kaller likevel dette henholdsvis «ikke-frivillig» (når personen ikke er samtykkekompetent) og «ufrivillig» (personen har ikke uttalt seg, er ikke forespurt, eller motsetter seg) eutanasi, og de må beskrive øvrige tilfeller som «frivillig eutanasi». Da det som foreslås når legalisering av eutanasi diskuteres, nesten alltid er den frivillige versjonen, er det gode grunner til å la eutanasi kun betegne situasjoner der personen har forespurt det. Det trengs også et begrep som dekker situasjoner der personen ikke har forespurt eutanasi. I forskningslitteraturen om Nederland og Belgia kalles dette «life-ending acts without explicit (patient) request» («LAWER»). Betegnelsen «barmhjertighetsdrap» brukes iblant, men den kan tolkes som positivt ladet, og betegnelsen som velges bør ikke forutsette at det er barmhjertighet som er motivasjonen. Jeg foreslår å kalle dette for «medisinske drap uten forespørsel». Siden dette ville være spesielt kontroversielt, og siden knapt noen har foreslått å tillate det i Norden, mener jeg den negativt ladede termen «drap» kan forsvares her.

«Assistert selvmord» kan - etter mal fra «eutanasi» - defineres som «å bidra til å forårsake personens død med hensikt, ved å bringe til veie dødbringende medikamenter som personen kan innta selv, på personens 
forespørsel». Det er vanligst å snakke om legeassistert selvmord. Men man kan tenke seg at annet helsepersonell er involvert i dette - som i Canada, der spesialsykepleiere kan stå for både eutanasi og assistert selvmord. I Sveits tillates lekfolk en sentral rolle i prosessen, men de dødbringende medikamentene må skrives ut av en lege som har undersøkt pasienten. Det er derfor grunn til å bruke et begrep som ikke begrenser denne handlingen til helsepersonell. I en konkret sammenheng kan begrepet spesifiseres nærmere, som $\mathrm{i}$ «legeassistert selvmord».

Det er uheldig i denne sammenhengen at «selvmord» er negativt ladet; og «mord» betegner jo et moralsk og juridisk uakseptabelt drap. Samtidig kan «selvmord» eller «selvdrap» hevdes å være en presis betegnelse, for handlingen vi her snakker om, innebærer at personen intenderer sin egen død - og får assistanse til å virkeliggjøre dette (Reed, 2019). «Selv-mord» er beskrivende, fordi personen - i motsetning til ved eutanasi - utfører den siste avgjørende handlingen selv. Videre er det ikke åpenbart at assisterte selvmord skiller seg radikalt fra andre selvmord (se kap. 11). Som med «eutanasi» taler det klart for «assistert selvmord» at det er et mye brukt og innarbeidet begrep. Kunne «assistert død» vært et alternativ, slik rapporten til svenske Smer (Statens medicinsk-etiska råd, 2017) foreslår med termen «assisterat döende»? Her skapes det potensial for misforståelser ved at de direkte engelskspråklige oversettelsene «assisted dying» og «assisted death» ikke nødvendigvis viser til «assistert selvmord» spesifikt, men like ofte brukes som samlebetegnelser på dette og eutanasi.

Hvilken plass er det da for «dødshjelp» eller «aktiv dødshjelp»? I Norge, Sverige, Danmark og Finland synes det å være ett av disse to begrepene som er klart mest kjent og mest brukt for å betegne dette feltet. Det er i seg selv et sterkt argument for fortsatt å gi begrepet en plass. Mitt forslag er derfor å la «dødshjelp» være en samlebetegnelse på eutanasi og assistert selvmord, slik blant annet Smer har gjort det. En ett-ords samlebetegnelse er nyttig for å unngå å måtte bruke den tunge formuleringen «eutanasi og assistert selvmord». Det er ofte behov for å omtale de to praksisene samlet, også fordi det i mange etikeres syn ikke er avgjørende prinsipielle etiske forskjeller mellom dem.

«Dødshjelp» er å foretrekke fremfor et begrep som «selvbestemt livsavslutning» eller Smers tidligere foretrukne «självvalt livsslut». De to 
sistnevnte begrepene presiserer ikke at det dreier seg om en annen persons «hjelp», og kunne derfor like gjerne innbefatte også vanlige selvmord samt behandlingsbegrensning. En ulempe med det foreslåtte samlebegrepet er at det er positivt ladet; «dødshjelp» innebærer en «hjelp».

Hvorfor kvitte seg med leddet «aktiv» i dødshjelpsbegrepet? A snakke om «aktiv» dødshjelp er misvisende av to grunner (Alvik, 2009; Materstvedt \& Førde, 2011). For det første er det ikke «aktivitet» som skiller eutanasi og assistert selvmord fra andre handlinger på dette feltet. For det andre inviterer «aktiv dødshjelp» til å etterlyse en "passiv dødshjelp» som det som en logisk følge skal stå i kontrast til. «Passiv dødshjelp» ble tidligere brukt - og brukes fremdeles av mange - som en betegnelse på behandlingsbegrensning, som diskuteres i neste avsnitt. Dødshjelp står ganske riktig i kontrast til behandlingsbegrensning. Men betegnelsen «behandlingsbegrensning» er velvalgt, og det er misvisende å kalle det «dødshjelp», og like misvisende å kalle det «passiv», for det innebærer aktive handlinger.

«Behandlingsbegrensning» eller «begrensning av livsforlengende behandling» er å avslutte, eller ikke starte, potensielt livsforlengende behandling hos en alvorlig syk pasient (Materstvedt et al., 2007). I motsetning til dødshjelp er behandlingsbegrensning normal, daglig praksis på sykehus og sykehjem. I Norden er det både klinisk, juridisk og etisk akseptert - og som prinsipp ukontroversielt. En viktig bakgrunn for dette er at moderne medisin har gitt oss muligheten til å holde pasienter kunstig i live også langt ut over det som er i pasientens interesse og menneskelig meningsfullt.

Selv om tilgangen til avansert livsforlengende behandling i seg selv er et gode, krever teknologien også at det noen ganger tas krevende valg, både av helsepersonell og av pasienter. Når er vi kommet dit at «nok er nok»? Er pasienten bedre tjent med god lindring den siste tiden fremfor «heroiske» tekniske intervensjoner som står i fare for bare å påføre plager og bivirkninger uten å være til nytte, og som til og med kan forlenge en lidelsesfull dødsprosess? Klinikere oppfatter det å avstå fra livsforlengende behandling i slike situasjoner som noe helt annet enn dødshjelp. Begrepet "passiv dødshjelp» er misvisende, fordi det indikerer at det bare er et subtilt skille mellom «aktivitet» og "passivitet» som er forskjellen på det å avslutte livsforlengende behandling og det å forårsake pasientens 
død gjennom en injeksjon. Jeg kommer tilbake til skillet mellom behandlingsbegrensning og dødshjelp i kapitlets siste del.

Begrepet «behandlingsbegrensning» kan imidlertid gi opphav til en uheldig feillesning, når det fortolkes som at all behandling avsluttes eller trappes ned. Men det viser kun til den (potensielt) livsforlengende behandlingen. Når denne trappes ned, avsluttes eller ikke påbegynnes, er det god medisin å trappe opp lindrende behandling ut fra pasientens behov. Den livsforlengende behandlingen det avstås fra, kan i prinsippet være alt fra avansert medisin slik som respirator-, pressor-, dialyse- og intensivbehandling, til antibiotika, væske- og ernæringsbehandling og hjerte-lungeredning. En beslutning om at sykehjemspasienten ikke skal legges inn på sykehus ved en medisinsk akuttsituasjon, men behandles på sykehjemmet, vil også kunne utgjøre en form for behandlingsbegrensning.

Oppsummert ser vi at ingen av de foreslătte begrepene er helt uten svakheter, på bakgrunn av kriteriene for gode definisjoner som ble introdusert innledningsvis. Begrepene og definisjonene er valgt fordi de - ut fra min argumentasjon - representerer den beste balansen mellom ulike hensyn. Her har jeg lagt særlig vekt på at de skal ligge tett opp til terminologien som allerede er kjent fra nordisk debatt og fra landene som har legalisert dødshjelp. Håpet er at en slik enhetlig begrepsbruk kan hjelpe oss til en bedre og mer saklig dødshjelpsdebatt i de nordiske landene. Den fremtidige utviklingen kan kreve at definisjonene justeres. Hvis for eksempel yrkesgrupper utenfor helsetjenesten får rett til å yte dødshjelp (Elliott, 1996), vil det være en grunn for å justere eutanasidefinisjonen, slik at den ikke spesifiserer helsepersonell som utøverne.

\section{Er det noen etisk relevant forskjell mellom eutanasi og behandlingsbegrensning?}

Jeg har argumentert for at den språklige oppdelingen av den medisinske virkeligheten bør skje slik at eutanasi/dødshjelp avgrenses tydelig fra behandlingsbegrensning. Men et viktig spørsmål er så hvilken relevans denne distinksjonen har for den etiske diskusjonen om dødshjelp.

Over hevdet jeg at eutanasi og behandlingsbegrensning er forskjellige handlinger, og at forskjellen følger av definisjonene. Den ene innebærer 
en dødbringende injeksjon som har til hensikt å forårsake død; den andre innebærer å avslutte, eller ikke starte, behandling som kunne ha forlenget livet. Men selv om disse praksisene er klinisk forskjellige, er det et åpent spørsmål om de er etisk forskjellige: Finnes det en etisk relevant forskjell mellom dem?

Spørsmålet er viktig fordi flere filosofer (og noen leger) vil hevde at det ikke finnes noen slik etisk relevant forskjell (Miller et al., 2010). Hvis de har rett, har vi ingen saklig grunn til å avvise eutanasi samtidig som vi aksepterer behandlingsbegrensning. Dødshjelpsmotstandere gjør seg i så fall skyldig i en selvmotsigelse.

Min erfaring er at helsepersonell noen ganger oppfatter problemstillingen som oppkonstruert og nokså virkelighetsfjern. For dem er det store og klare forskjeller i praksis mellom eutanasi (som de holder seg fra) og behandlingsbegrensning (som de praktiserer hyppig som ledd i normal klinisk praksis). Det er opplagt en forskjell mellom det å injisere dødbringende medikamenter og, for eksempel, å avstå fra hjertetransplantasjon. Likevel er det nødvendig å kunne gi et svar på hva den eller de etisk relevante forskjellene eventuelt består i. Utgangspunktet for en observatør kan jo være at begge er handlinger/beslutninger som leder til pasientens død, ved at døden fremskyndes, i den forstand at den kommer tidligere enn den ellers ville gjort. Hva består så de forskjellene i som rettferdiggjør at vi aksepterer den ene handlingen, men avviser den andre?

\section{To mulige forskjeller}

Én mulig forskjell beskrev jeg over: Eutanasi er «aktivt», mens behandlingsbegrensning er "passivt». Men selv om behandlingsbegrensning noen ganger kan innebære "passivitet» $\mathrm{i}$ form av unnlatelser, som ved beslutningen om ikke å starte en gitt behandling, er det minst like typisk for behandlingsbegrensning at det innebærer en lang rekke aktive handlinger. Dette kan være gradvis nedtrapping og fjerning av apparatur (som en respirator) og samtidig opptrapping av annen (lindrende) behandling. Aktiv-passiv-distinksjonen er derfor ikke treffende som analyse av hva som skiller eutanasi og behandlingsbegrensning fra hverandre. 
En annen mulighet er mer lovende: Ved eutanasi dør pasienten av helsepersonellets handling (den dødbringende injeksjonen), mens ved behandlingsbegrensning dør pasienten av sin grunnsykdom. Dette er opplagt langt på vei riktig, og vises hyppig til som forklaringen på hvordan eutanasi og behandlingsbegrensning er to ulike praksiser, blant annet i det norske Helsedirektoratets veilederdokument om behandlingsbegrensning (Helsedirektoratet, 2013, s. 10). Men problemet er at distinksjonen ikke alltid gjelder. For i noen tilfeller av behandlingsbegrensning er det treffende å si at helsepersonellets handlinger/beslutninger i det minste er medvirkende årsaker til pasientens død. Det ser vi tydeligst i situasjoner der pasientens tilstand er stabil og livet opprettholdes av medisinske tiltak. Ett eksempel kan være respiratorbehandling for amyotrofisk lateralsklerose (ALS). Når respiratorbehandlingen trappes ned og tas vekk, dør pasienten ganske riktig av sin grunnsykdom. Men pasienten dør også på grunn av beslutningen om å stoppe behandlingen og de handlingene som følger derav. Det er en medvirkende årsak til døden. Et annet eksempel er væske- og ernæringsbehandling ved persisterende vegetativ tilstand (PVS). I likhet med ALS-pasienten kunne denne pasienten levd lenge kanskje i årevis - hvis ikke beslutningen om å stoppe behandling ble fattet og effektuert. Helsepersonellets handlinger er, sammen med pasientens grunnsykdom, åpenbart medvirkende årsaker til at pasienten dør, og at det skjer akkurat nå. Hvis skillet mellom eutanasi og behandlingsbegrensning ikke svarer til skillet mellom å $\mathrm{d} ø$ av helsepersonellets handling og å dø av grunnsykdommen, kan dette heller ikke være en etisk relevant forskjell mellom praksisene.

\section{Intensjon som etisk relevant forskjell}

En tradisjonell og utbredt oppfatning er at det er intensjonen som er den etisk relevante forskjellen mellom eutanasi og behandlingsbegrensning, og dette er også mitt syn. Ved eutanasi intenderer helsepersonellet pasientens død. Det er de «nødt» til, når de med overlegg setter dødelige medikamentdoser. Ved behandlingsbegrensning er det i teorien også mulig å intendere pasientens $\mathrm{d} ø \mathrm{~d}$, men andre intensjoner er mye vanligere $\mathrm{i}$ praksis: Hensikten med behandlingsbegrensning er å skåne pasienten for 
behandling som ikke lenger er nyttig, effektiv eller ønsket, eller å skåne pasienten for behandling der nytten (i form av livsforlengelse) ikke oppveies av ulempene (særlig i form av bivirkninger og plager ved behandling), eller å unngå å forlenge en lidelsesfull dødsprosess.

Nøyaktig hva er en «intensjon»? En handlendes intensjoner er formålene denne har med handlingen, det er planen for handlingen, det som faktisk velges. Filosofen Joseph Shaw definerer det mer presist som at et fremtidig faktum er intendert hvis - og bare hvis - den handlende blir motivert til a handle (eller avstå fra handling) av forventningen om at handlingen (eller unnlatelsen) vil gjøre det mer sannsynlig at dette faktum vil bli virkelighet (Shaw, 2006, s. 206). Ikke alle konsekvenser av våre handlinger, heller ikke de som vi vet med full sikkerhet vil inntreffe, er nødvendigvis del av vårt formål, vår plan eller vår motivasjon. Når jeg sykler, intenderer jeg ikke å påføre slitasje på sykkeldekkene, selv om det er en garantert og forutsett konsekvens av sykkelturen. Selv om vi vet at behandlingsbegrensning i en gitt situasjon vil medvirke til at pasientens død kommer tidligere enn den ellers ville ha gjort, trenger ikke det å fremskynde døden å være en del av vårt formål og vår motivasjon. Derimot kan vi være motivert av ikke å ville uthale en plagsom dødsprosess. Dette er ikke det samme som å intendere pasientens død, som alltid vil være en sentral og umiskjennelig del av intensjonen ved eutanasi. Forskjellen kan vi også få frem ved et «kontrafaktisk testspørsmål»: Hvis pasienten ikke hadde dødd, og døden ikke hadde blitt fremskyndet, ville handlingen og den handlendes plan da vært mislykket? Ved eutanasi er svaret «ja». Men ved behandlingsbegrensning er svaret «nei», for formålet var ikke å fremskynde pasientens død, men å avstå fra behandling som ikke lenger var i pasientens interesse. Intensjon er heller ikke det samme som ønske: Vi kan ønske at pasienten skal «få slippe», at døden skal komme raskt, uten at det av den grunn er formålet med behandlingsbegrensningen. Ingen handling følger av et ønske, til det trengs en intensjon (Materstvedt \& Bosshard, 2009).

En innvending kan være at forskning viser at leger faktisk ofte intenderer pasientens død ved behandlingsbegrensning. Første tilsvar til dette er at i de tilfellene det er slik, er legens handling moralsk problematisk i den forstålsen som her er skissert. Like mye som eutanasi her er moralsk problematisk, fordi det innebærer en intensjon om å forårsake pasientens 
død, er behandlingsbegrensning moralsk problematisk i de tilfeller der det innebærer samme intensjon. Men andre tilsvar er at denne forskningen har betydelige svakheter, noe jeg har redegjort for i detalj annetsteds (Magelssen et al., 2016; Magelssen \& Shaw, 2020). Typisk innebærer den spørreskjemaundersøkelser med ledende svarkategorier, utført på respondenter som har ulike oppfatninger av hva «intensjon» innebærer. Eksempelvis har de store nederlandske undersøkelsene stilt enkelte «låste» spørsmål som kobler legers befatning med behandlingsbegrensning til en intensjon om å fremskynde pasientens død. Det finnes derfor ingen troverdig forskning som har etablert at helsepersonell hyppig intenderer pasientens død når de begrenser livsforlengende behandling.

Hvorfor er intensjon viktig i etikken? Våre intensjoner har etisk betydning fordi det er disse som gir våre handlinger deres karakter, ut fra om vi tar sikte på gode, nøytrale eller onde formål. Gjennom det du intenderer, binder du deg til en plan for handlingen - og implisitt til en oppfatning av godt og ondt. Handlingen og dens intensjoner er uttrykk for den handlendes moralske karakter (McClelland \& Goligher, 2019). Merk at jeg i dette kapitlet ikke har vist at det er galt å intendere noens død og at dødshjelp derfor er uetisk. Men jeg har beredt grunnen for et slikt argument, ved å vise at dødshjelp er karakterisert ved intensjonen om personens død, og at det dermed er noe annet enn behandlingsbegrensning og normal medisinsk praksis.

I denne avsluttende delen av kapitlet har spørsmålet altså vært om det er noen prinsipiell etisk forskjell som kan begrunne at eutanasi kan være prinsipielt moralsk problematisk, samtidig som behandlingsbegrensning er prinsipielt moralsk akseptabelt. En slik forskjell mener jeg å ha identifisert - i handlingens intensjon. Dette betyr samtidig at i den grad en behandlingsbegrensning innebærer en intensjon om pasientens død, er den problematisk på samme måte som eutanasi er det.

\section{Referanser}

Alvik, A. (2009). Dødshjelp - i medisinens randsone? Michael, 6, 499-504. Hentet fra https://www.michaeljournal.no/i/2009/12/Dødshjelp-i-medisinens-randsoneElliott, C. (1996). Philosopher assisted suicide and euthanasia. BMJ, 313(7064), 1088. 
Gaasø, O. M., Rø, K. I., Bringedal, B. \& Magelssen, M. (2019). Legers holdninger til aktiv dødshjelp. Tidsskr nor legeforen, 139(1), 31-35. Hentet fra https://tidsskriftet. no/2019/o1/originalartikkel/legers-holdninger-til-aktiv-dodshjelp

Helsedirektoratet. (2013). Beslutningsprosesser ved begrensning av livsforlengende behandling. (IS-2091). Hentet fra https://helsedirektoratet.no/Lists/Publikasjoner/ Attachments/67/IS-2091-Beslutningsprosesser-ved-begrensning-avlivsforlengende-behandling.pdf

Magelssen, M., Kaushal, S. \& Nyembwe, K. A. (2016). Intending, hastening and causing death in non-treatment decisions: A physician interview study. Journal of Medical Ethics, 42(9), 592-596.

Magelssen, M. \& Shaw, J. (2020). Intentions of physicians and end of life care team. I N. Emmerich, P. Mallia, B. Gordijn \& F. Pistoia (Red.), Contemporary European perspectives on the ethics of end of life care. Basel: Springer.

Magelssen, M., Supphellen, M., Nortvedt, P. \& Materstvedt, L. J. (2016). Attitudes towards assisted dying are influenced by question wording and order: A survey experiment. BMC Medical Ethics, 17 . Hentet fra https://bmcmedethics. biomedcentral.com/articles/10.1186/s12910-016-0107-3

Materstvedt, L. J. \& Bosshard, G. (2009). Deep and continuous palliative sedation (terminal sedation): Clinical-ethical and philosophical aspects. The Lancet Oncology, 10(6), 622-627.

Materstvedt, L. J., Clark, D., Ellershaw, J., Førde, R., Gravgaard, A. M., MüllerBusch, H. C., Porta i Sales, J., Rapin, C. H. ... EAPC Ethics Task Force. (2003). Euthanasia and physician-assisted suicide: A view from an EAPC ethics task force. Palliative Medicine, 17, 97-101.

Materstvedt, L. J., Førde, R., Kaasa, S. \& Borchgrevink, P. (2007). Eutanasi definisjonsmessige, etiske og kliniske betraktninger i et internasjonalt perspektiv. I S. Kaasa (Red.), Palliasjon. Nordisk loerebok (s. 153-178). Oslo: Gyldendal Akademisk.

Materstvedt, L. J. \& Førde, R. (2011). Fra aktiv og passiv dødshjelp til eutanasi og behandlingsbegrensning. Tidsskr nor legeforen, 131, 2138-2140. Hentet fra https:// tidsskriftet.no/2011/11/kronikk/fra-aktiv-og-passiv-dodshjelp-til-eutanasi-ogbehandlingsbegrensning

McClelland, W. \& Goligher, E. C. (2019). Withholding or withdrawing life support versus physician-assisted death: A distinction with a difference? Curr Opin Anaesthesiol, 32(2), 184-189.

Miller, F. G., Truog, R. D. \& Brock, D. W. (2010). Moral fictions and medical ethics. Bioethics, 24(9), 453-460.

Moen, O. M. \& Sterri, A. B. (2019). Aktiv dødshjelp. Etikk ved livets slutt. Oslo: Cappelen Damm Akademisk. 
Pedersen, R. \& Aarre, T. (2017). Autonomi, informert samtykke og samtykkekompetanse. I R. Pedersen \& P. Nortvedt (Red.), Etikk i psykiske helsetjenester (s. 153-167). Oslo: Gyldendal Akademisk.

Reed, P. (2019). Is "aid in dying" suicide? Theoretical Medicine and Bioethics, 4o(2), 123-139.

Shaw, J. (2006). Intention in ethics. Canadian Journal of Philosophy, 36(2), 187-224. Staff-Poulsen, I. (2019, 2. februar). Aktiv dødshjelp - «Vedlagte kronikk er kanskje litt kontroversiell - fordi jeg er død». Dagbladet. Hentet fra https:/www.dagbladet.no/ kultur/vedlagte-kronikk-er-kanskje-litt-kontroversiell---fordi-jeg-er-dod/70706493 Statens medicinsk-etiska råd. (2017). Dödshjälp. En kunskapssammanställning (Smer rapport 2017:2). Hentet fra http://www.smer.se/wp-content/uploads/2017/11/ Smer-2017.2-Dödshjälp-En-kunskapssammanställning.pdf

\section{Ordforklaringer}

etterlyse: uppmana (S), opfordrer (D)

forespørsel: förfrågan $(\mathrm{S})$

foretrukne: föredragna $(S)$

forskjell: skillnad (S), forskel (D)

hensikt: avsikt (S)

hyppig: frekvent (S)

kun: bara (S)

langt på vei: i stor utsträckning (S), i vid utstrækning (D)

med overlegg: medvetet (S), bevidst (D)

måten: hur (S), den måde (D)

nødt til: måste (S)

nøyaktig: exakt (S), præcis (D)

over hevdet jeg: ovan hävdade jag (S)

sjeldne: sällsynta (S), sjældne (D)

skillet: skillnaden (S)

spørreskjemaundersøkelser: frågeformulär/enkäter (S), spørgeundersøgelser (D)

tilsvar: svar

trengs: behövs (S)

trukket: dragit (S)

uheldig: olycklig (S)

underslår: underskattar (S), undervurderer (D)

utilsiktet: oavsiktlig (S)

uthale: förhala/förlänga (S), forhale/forlænge (D) 



\title{
KAPITTEL 3
}

\section{Dødshjelp: Lovverk, praksis og holdninger i de skandinaviske land}

\author{
Daniel Joachim H. Kleiven
}

Siviløkonom, masterstudent i filosofi og samfunnsdebattant

\section{Ole Hartling}

Vejle Sygehus

\section{Fabian Ståhle}

Claphaminstitutet

\section{Morten A. Horn}

Oslo universitetssykehus

\section{Morten Magelssen}

\section{Senter for medisinsk etikk, Universitetet i Oslo}

\begin{abstract}
Why a book on assisted dying in the Nordic countries? The Nordic countries share many similarities, both culturally and in terms of their legal systems, and we have much to learn from each other. In this chapter, we briefly describe legislation and practices with assisted dying in the three Scandinavian countries. Denmark, Norway and Sweden are characterised by restrictive assisted dying legislation. As expressed in surveys, the majority of their general populations seems to support legalisation of assisted dying, while health professionals and politicians are more negative to legalisation. This interesting disparity and its implications are discussed at the end of the chapter.
\end{abstract}

Keywords: assisted dying, euthanasia, legislation, opinion polls, public opinion, survey 


\section{Innledning}

Dette kapitlet tar for seg lovverket som regulerer dødshjelp, hva man vet om (illegal) praksis, og holdningene til dødshjelpsspørsmålet i befolkningen og blant fagfolk og beslutningstakere i Danmark, Norge og Sverige. For hvert av temaene prøver vi å belyse likheter og forskjeller mellom disse landene. Finland står i en særstilling, fordi man der allerede har vært gjennom en omfattende parlamentarisk behandling av et lovforslag om dødshjelp. Finland drøftes i detalj i kap. 4.

Fordi kapitlet er skrevet av representanter fra tre land, blir teksten en blanding av dansk, norsk og svensk. Vi har likevel tilstrebet en felles terminologi for dødshjelpsrelaterte emner, og viser til definisjonene i kap. 2.

Den siste delen av kapitlet er en kritisk refleksjon over befolkningsundersøkelser om dødshjelp, som spiller en vesentlig rolle i ordskiftet i de nordiske landene.

\section{Lovverk og praksis i de skandinaviske land}

\subsection{Lovgivning og praksis i Danmark}

Straffelovens $₫ 237$ til $₫ 241$ omhandler dette at tage livet af et medmenneske, hvor overtrædelse af $\$ 237$ (manddrab) anses for den alvorligste og $\$ 241$ (uagtsomt manddrab) for den mildeste lovovertrædelse.

$\$ 237$ siger kort: »Den som dræber en anden, straffes for manddrab med fængsel fra 5 år indtil på livstid«. $\$ 238$ handler om en moders drab af sit nyfødte barn. $\$ 239$ lyder: »Den, som dræber en anden efter dennes bestemte begæring, straffes med fængsel indtil 3 år« (svarer til dødshjælp). $\$ 240$ siger: »Den, som medvirker til, at nogen berøver sig selv livet, straffes med bøde eller fængsel indtil 3 år« (svarer til assisteret selvmord). Straffeloven er senest revideret i 2019, men disse paragraffer er uændrede.

I forbindelse med spørgsmålet om dødshjælp er det således $\$ 237 \mathrm{og}$ især $\$ 239$ og $\$ 240$, der er relevante. I daglig tale vil lovovertrædelserne efter $\$ 239$ og $\$ 240$ ofte være synonyme med »medlidenhedsdrab« eller »barmhjertighedsdrab«. Det er uhyre sjældent, men i de få tilfælde, det er forekommet, har domstolene idømt milde straffe for eksempel betinget fængsel, idet der er taget hensyn til omstændighederne såsom 
desperation og fortvivlelse, og at lovovertræderen i princippet har handlet uegennyttigt.

Sundhedslovens $\$ 25$ omhandler »uafvendeligt døende patienter«, det vil sige, at døden kan forventes inden for højst nogle dage. $\$ 25$, stk. 1: „Såfremt en uafvendeligt døende patient ikke længere er i stand til at udøve sin selvbestemmelsesret, kan en sundhedsperson undlade at påbegynde eller fortsætte en livsforlængende behandling«. Stk. 2: „En uafvendeligt døende patient kan modtage de smertestillende, beroligende eller lignende midler, som er nødvendige for at lindre patientens tilstand, selv om dette kan medføre fremskyndelse af dødstidspunktet«. Tankegangen bag bestemmelserne er, at man ikke må være så bange for døden, at man ikke lindrer, for det er sundhedspersonen forpligtet til.

I 2018 vedtog Folketinget en tilføjelse til Sundhedsloven, hvorved det såkaldte livstestamente blev erstattet af muligheden for at oprette et »behandlingstestamente«. Dette kan gøres på et tidspunkt, hvor testator (borgeren) er beslutningsdygtig (habil). I behandlingstestamentet kan borgeren bestemme, at behandling ikke skal gives i tre specifikke situationer: 1) Hvis lægerne vurderer, at døden er nært forstående, 2) hvis man bliver så svært invalideret, at man ikke længere kan klare sig selv hverken fysisk eller mentalt, eller 3 ) hvis man kommer i en tilstand, hvor de fysiske konsekvenser af sygdommen eller behandlingen er forbundet med alvorlig svækkelse eller stor lidelse. Borgeren kan også bestemme, at han eller hun ikke ønsker at blive behandlet med tvang ved varig inhabilitet for eksempel på grund af demens.

Der har været mulighed for at oprette et behandlingstestamente siden 2019. For behandlingstestamentet gælder, at det kun træder i kraft, hvis testator ikke længere er habil. Forskellen på livstestamentet og behandlingstestamentet er, at mens førstnævnte kun var juridisk bindende for behandleren, hvis patienten var uafvendeligt døende, er et behandlingstestamente juridisk bindende fra det øjeblik, patienten er i en udsigtsløs tilstand og ikke længere er habil og i stand til at tage vare på sig selv. Man kan vælge at gøre testamentet betinget af accept fra nærmeste pårørende og/eller en på forhånd udpeget »fremtidsfuldmægtig«.

I debatten om dødshjælp høres den påstand, at det ifølge loven ikke er noget, vi har i Danmark, men vi har det nok alligevel i det skjulte. 
Opfattelsen bygger ikke sjældent på, hvad pårørende fortæller. Den tidsmæssige følge af indgift af smertestillende og beroligende medicin hos et døende menneske, og at døden herefter indtræder, opfattes let som en kausal følge af medicineringen. I den gråzone, som overgangen fra livet til døden er, søges de kausale sammenhænge og en slags mening med eller en forklaring på, at døden indtræder nu.

I 1994-95 var der en afgørende sag på et københavnsk sygehus, hvor en familie klagede over, at den intravenøse morfindosis hos deres pårørende var blevet øget pr. automatik, indtil døden indtraf. Dette førte til, at Sundhedsstyrelsen gav den pågældende afdeling en påtale og efterfølgende indskærpede retningslinjerne for smertebehandling af døende, nemlig at smertelindring kun må gives på indikationen "smerter« - medicindoseringen skal være »smertestyret«. Dette er blevet forstået og indbygget i procedurerne på landets sygehusafdelinger, og i dag er intravenøse "smertedrop« sjældne; og indgivet på den omtalte måde med automatiske dosisøgninger forekommer de praktisk talt ikke.

\subsection{Lovverk og praksis i Norge}

Dødshjelp er forbudt i Norge, og reguleres nå av straffeloven av 2005 som trådte i kraft i 2015. Slik var situasjonen også tidligere, etter straffeloven av 1902. Dette spørsmålet ble eksplisitt diskutert i Stortinget da ny straffelov ble gitt. Straffelovens $\$ 275$ kriminaliserer drap - med en strafferamme på 8 til 21 år. I $\$ 276$ gis det mulighet for nedsatt straff om den avdøde ga samtykke til eget drap. I $\$ 277$ kriminaliseres likedan medvirkning til selvmord med fengsel i 8 til 21 år. $\$ 278$ åpner imidlertid for nedsatt straff om «noen av medlidenhet dreper en person som er dødssyk, eller som av andre grunner er nær ved å dø».

Kun én norsk lege er domfelt for å ha utført dødshjelp. Den pensjonerte legen Christian Sandsdalen ga i 1996 en dødelig dose morfin og ketobemidon til en sterkt svekket pasient med multippel sklerose. Han meldte selv saken inn til riksadvokaten - i håp om å starte en prosess for å få legalisert dødshjelp gjennom rettssystemet. Sandsdalen ble dømt for overlagt drap i både byrett og lagmannsrett, men med domsutsettelse. Anken til Høyesterett ble avvist i år 2000, og Sandsdalen døde senere 
samme år. Han ble ekskludert fra Den norske legeforening før det forelå en rettskraftig dom.

En annen lege, Stein Husebø, innrømmet i 1992 at han hadde gitt dødshjelp i form av eutanasi til en terminal kreftpasient (Husebø, 2009). Saken ble aldri behandlet i rettsapparatet, fordi riksadvokaten ga påtaleunnlatelse, men Husebø fikk en advarsel fra Helsetilsynet. Han ble senere en profilert motstander av legalisering av dødshjelp. En tredje lege, Christian Borchgrevink, fortalte offentlig at han hadde utdelt medikamenter til pasienter for bruk til selvmord, men heller ikke han ble rettsforfulgt av påtalemyndigheten.

I henhold til en anonym spørreundersøkelse fra 2014 blant norske leger ser det ut til at illegal dødshjelp er lite utbredt (Førde \& Aasland, 2014). 1279 leger ble spurt om de det siste året hadde utført handlinger med intensjon om å framskynde pasientens død. Én anga å ha utført eutanasi, én legeassistert selvmord. Det er vanskelig å generalisere funnene til hele den norske legestanden, men med utgangspunkt $\mathrm{i}$ at Norge har om lag 25 ooo yrkesaktive leger, ville det ha tilsvart ca. 40 illegale dødshjelpstilfeller i Norge årlig. I tillegg svarte fire av respondentene at de hadde framskyndet døden uten at pasienten ba om det.

Til tross for at det trolig foregår noe illegal dødshjelp i Norge, har altså ingen leger blitt anklaget og dømt for dette, bortsett fra dem som selv har stått fram. Fra tid til annen anklages helsevesenet for å gi «dødshjelp» til pasienter, men dette handler typisk om handlinger som ikke er dødshjelp: Feilbehandling med dødelig utgang, pasienter som nektes behandlingen de ønsker, eller konflikter rundt behandlingsbegrensning (se kap. 2).

Behandlingsbegrensning er juridisk ukontroversielt i Norge, som i resten av Skandinavia (Førde, Materstvedt \& Syse, 2008). Pasientrettighetsloven av 1999 slår fast at all behandling, også den som opprettholder livet, i utgangspunktet krever pasientens samtykke. \$ 4-9 slår eksplisitt fast at døende pasienter som er samtykkekompetente, kan avstå fra eller kreve avslutning av livsforlengende behandling, selv om en slik beslutning medfører at pasienten dør. Dersom pasienten mangler samtykkekompetanse, kan legen beslutte å avslutte livsforlengende behandling. Det skal skje gjennom beslutningsprosesser beskrevet i en nasjonal veileder fra Helsedirektoratet (2009, revidert i 2013). Dersom konflikter oppstår, løses 
de enten gjennom samtaler med berørte parter, ved at man ber om en faglig fornyet vurdering - såkalt «second opinion» - fra et annet sykehus, eller gjennom møter i de kliniske etikk-komiteene som finnes ved alle landets sykehus (Magelssen, Pedersen \& Førde, 2018).

Forhåndsdirektiver, også kalt «livstestament», hvor pasienten beskriver sine preferanser for livsforlengende tiltak ved livets slutt, har ingen offisiell status i norsk lovverk. De er ikke juridisk bindende og heller ikke så utbredt. De vektlegges imidlertid som kilder til kunnskap om pasientens ønsker.

I Norge ble det kontrovers rundt lindrende sedering i kjølvannet av den såkalte Bærums-saken fra 1999. Der ble en palliativmedisiner anklaget av en kollega for å ha gitt «dødshjelp» i form av lindrende sedering. Saken ble, etter en lengre prosess, henlagt etter bevisets stilling. Etter dette utarbeidet Den norske legeforening egne retningslinjer for lindrende sedering, i tråd med internasjonale retningslinjer. Tross dette mener palliativmedisinere at norsk helsevesen fortsatt ikke har tatt i bruk lindrende sedering i det omfanget pasientenes behov tilsier (Materstvedt, Ottesen, von Hofacker \& Syse, 2019; se grundigere omtale av lindrende sedering i kap. 10).

\subsection{Svensk lag och praxis}

I fråga om assisterat självmord föreligger det en speciell situation i Sverige som har en stor betydelse i debatten om dödshjälp. Att medverka till att en människa begår självmord är inte brottsligt. Motiveringen till detta är att eftersom självmord inte är en brottslig handling kan inte heller medverkan till handlingen vara brottslig. Assistera vid ett självmord faller alltså inte under brottsbalken och är inte straffbart för gemene man.

Men läkare och vårdpersonal lyder under patientsäkerhetslagen som stadgar att sjukvården ska bedrivas i överensstämmelse med vetenskap och beprövad erfarenhet, vilket assisterat självmord inte anses vara uttryck för. Den läkare som skriver ut ett dödligt medel skulle därmed riskera att mista sin legitimation.

De lagar och regler som är aktuella i Sverige i fråga om dödshjälp är Europakonventionen om skydd för de mänskliga rättigheterna, brottsbalken (1962:700), hälso- och sjukvårdslagen (2017:30), patientsäkerhetslagen 
(2010:659) och patientlagen (2014:821). När det gäller att inte inleda eller inte fortsätta livsuppehållande behandling regleras detta av Socialstyrelsens föreskrifter och allmänna råd om livsuppehållande behandling på så sätt att medicinska åtgärder som gör mer skada än nytta ska undvikas eller avbrytas.

Med undantag för de fall som omfattas av lagen för psykiatrisk tvångsvård får, enligt patientlagen, hälso- och sjukvård inte ges utan patientens samtycke. En patient har därmed också rätt att avstå från livsuppehållande behandling och kan alltså kräva att en sådan åtgärd genast avbryts eller aldrig vidtas. Detta under förutsättning att patienten har fått information om sitt hälsotillstånd och de möjligheter som finns till medicinsk förbättring och smärtlindring - och att patienten bedöms beslutskapabel.

Patienten kan däremot inte bestämma innehållet och omfattningen av vården, än mindre begära att bli berövad livet med sjukvårdens aktiva hjälp.

Liksom i Danmark finns bland allmänheten en spridd uppfattning att dödshjälp ändå utförs genom överdosering av smärtlindrande preparat såsom morfin. Men det finns inga belägg för att svensk sjukvård överdoserar morfin i avsikt att förkorta livet hos patienter. Inom sjukvården har det snarare funnits en tendens att undermedicinera morfin i fruktan att preparatets andningshämmande effekt skulle påskynda patientens död med möjliga legala konsekvenser för den förskrivande läkaren. Men den populära uppfattningen om överdosering lever kvar och påverkar inställningen till en legalisering - det pågår ju ändå i det fördolda och då är det lika bra att det kontrolleras genom en »strikt» lagstiftning, kan man mena (se också kap. 10).

Åsiktsutbytet om dödshjälp påverkas också av att palliativ sedering av förespråkarna ibland framställs som en förtäckt form av eutanasi eftersom en kontinuerlig sedering kombineras med avbruten tillförsel av näring och vätska, vilket ofelbart leder till döden. Praxis är dock att en sådan åtgärd endast sätts in då patienten har svår smärta som inte kan lindras på annat sätt - och i det absoluta livsslutet när ändå vitala organ har börjat svikta (se kap. 10).

Att assistera ett självmord är alltså inte straffbart i Sverige, men leder till disciplinära åtgärder för sjukvårdspersonal. Däremot betraktas eutanasi som ett dråp med ett minimistraff på 6 års fängelse. Straffvärdet 
kan minska om brottet har föranletts av medkänsla och/eller samtycke vilket illustreras av några rättsfall. Senhösten 2019 föll domen i det omtalade Kramforsfallet där en man hade dödat sin ME-sjuka hustru - på hennes begäran - med en morfininjektion. Mannen dömdes av Ångermanlands tingsrätt till $1 \frac{1}{2}$ års fängelse, vilken dom kommer att överklagas enligt mannens försvarsadvokat.

Om dödshjälp skulle introduceras i Sverige någon dag, skulle då sjukvårdspersonal ha rätt att följa sitt samvete och vägra att delta? Till skillnad från i Danmark och Norge finns det ingen tradition i Sverige att sjukvårdspersonal får reservera sig av samvetsskäl, till exempel mot deltagande i abort. Svensk lagstiftning och praxis på detta område har kritiserats för att inte ha uppfyllt bestämmelserna om samvetsfrihet $\mathrm{i}$ Europeiska konventionen om mänskliga rättigheter (Fahlbeck, 2017).

\section{Holdninger til dødshjelp i de skandinaviske land}

\subsection{Holdninger til dødshjælp i Danmark}

Mange års erfaring med dansk dødshjælpsdebat viser, at særlig to argumenter går igen i mediernes fremstilling: 1) man må afhjælpe lidelse og derved handle i patientens bedste interesse, og 2) at enhver har en fri vilje og skal selv bestemme over sit liv og sin død. Forskellige meningsmålinger med udgangspunkt i disse argumenter viser her som $i$ andre lande et ret konstant flertal på $70 \%-80 \%$ for en lovliggørelse.

En undersøgelse blandt danske geriatere viste, at af de 120 , som besvarede spørgeskemaet, fandt $56 \%$ og $64 \%$, at henholdsvis eutanasi og lægeassisteret selvmord ikke er etisk forsvarligt (Matzen, Ilvemark \& Dahle, 2016). En avisundersøgelse fra 2017 med deltagelse af 410 læger fra forskellige specialer viste, at otte ud af 10 læger mente, at dødshjælp fortsat skulle være forbudt (Funch, 2017).

Lægeforeningen har gennem årene været imod en lovliggørelse af dødshjælp, men har først udtrykt dette direkte med vedtagelse af »Lægeforeningens etiske principper « $\mathrm{i}$ april 2018. Heri hedder det eksplicit i punkt 15: »Lægen må aldrig handle med hensigt om at forårsage patientens død eller medvirke til patientens selvmord«. 
Etisk Nævn i Lægeforeningen bragte de nye etiske principper i anvendelse i efteråret 2018, da et medlem, den pensionerede læge Svend Lings, i flere tilfælde havde vejledt om og udskrevet medicin med henblik på patienters selvmord. Lings havde kun et perifert kendskab til de patienter, som han vejledte. Etisk Nævn udtalte, at lægen havde handlet i klar strid med de etiske principper.

Dansk Sygeplejeetisk Råd udtalte sig i 2009 om dødshjælp, hvor de henviste til de sygeplejeetiske retningslinjer, hvor der i 2.1 bl.a. står: „Sygeplejersken må ikke medvirke til behandling, der alene har til hensigt at fremskynde en patients død«. Grete Christensen er formand for Dansk Sygeplejer, som er de danske sygeplejerskers faglige organisation. Hun har i 2020 bekræftet at Sygeplejerådet følger det Sygeplejeetiske Råds indstilling i dette spørgsmål (personlig meddelelse til $\mathrm{OH}$ ).

Det Etiske Råd, som har 17 medlemmer, vejleder Folketinget og regeringen i etiske spørgsmål. Det Etiske Råd har udtalt sig om legalisering af dødshjælp flere gange. I 1996 i »Dødshjælp? - en redegørelse« med 16 medlemmer imod og et for; i 2003 i »Eutanasi - lovliggørelse af drab på begæring? « med alle 17 medlemmer imod og i 2012 i »Det Etiske Råds udtalelse om eventuel lovliggørelse af dødshjælp«, hvor 15 medlemmer var imod og to delvist for. I en kronik fra december 2019 i en førende dansk avis (Politiken) står Det etiske Råd som forfatter. De skriver, at debatten om dødshjælp mere bør fokusere på, hvordan den palliative behandling kan forbedres end på en lovliggørelse (dette blev også et meget vigtigt tema i den finske debat, se kap. 4).

Den indflydelsesrige patientforening "Kræftens Bekæmpelse» mener ikke, at vi skal have dødshjælp i Danmark og tilføjer, »at den gældende lovgivning gør det muligt for alle borgere at få en værdig død med de kompetencer, som sundhedspersonalet har, og de muligheder for lindring, der allerede findes i dag.«

\subsection{Holdninger til dødshjelp i Norge}

I flere norske spørreundersøkelser de siste tiårene har en klar majoritet uttrykt støtte til legalisering av dødshjelp i visse situasjoner. Den siste omfattende undersøkelsen ble utført i 2015. Av respondentene var $76 \%$ 
«litt enig» eller «svært enig« i at legeassistert selvmord burde være tillatt for mennesker med en dødelig sykdom og kort forventet levetid. $68 \%$ var »litt enig" eller "svært enig" $i$ at eutanasi burde være tillatt i tilsvarende situasjoner. Undersøkelsen hadde imidlertid lav svarprosent, kun 13,5\% (Magelssen et al., 2016).

Helsepersonell er betydelig mer negative til dødshjelp enn den øvrige befolkningen. I en spørreundersøkelse fra 2016 blant 1605 leger var bare $22 \%$ «litt enig» og $9 \%$ «svært enig» i legalisering av legeassistert selvmord for personer med en dødelig sykdom og kort forventet levetid. For eutanasi i tilsvarende situasjon var tallene $17 \%$ og $8 \%$ (Gaasø et al., 2019). Andelen positive leger var større enn i 1993, da $17 \%$ ønsket legalisering av eutanasi, men med ulike spørsmålsformuleringer lar ikke tallene seg sammenligne direkte (Førde et al., 1997). Hovedfunnet er at flertallet av leger - nå som da - er motstandere av dødshjelp.

En undersøkelse fra 2014 viste at selv om dødshjelp hadde vært lovlig, ville kun $9 \%$ av legene selv vært villige til å utføre det (Gaasø et al., 2019).

Den norske legeforening og Norsk Sykepleierforbund tar klar avstand fra dødshjelp i sine profesjonsetiske retningslinjer. Etikkrådet for farmasøyter tok enstemmig avstand fra legalisering av assistert selvmord som ville krevd deltakelse fra farmasøyter, i en uttalelse (Etikkrådet for farmasøyter, 2010).

Noen pasientforeninger, som Norges Handikapforbund (2019, s. 4), er uttalte motstandere av dødshjelp. Ingen norske pasientforeninger har så langt gått inn for legalisering av dødshjelp. Foreningen Retten til en verdig død er en interesseorganisasjon som arbeider for legalisering av dødshjelp. Denne foreningen ble opprettet i 1977 og har per 2019 omkring 3500 medlemmer. Den arbeider også med distribusjon av et livstestament, som har til formål å formidle pasientens vilje og forhindre overbehandling dersom pasienten mister samtykkekompetansen.

\subsection{Inställningar till dödshjälp i Sverige}

På uppdrag av Aftonbladet gjorde Sifo år 2010 en undersökning där 1000 personer fick frågan: »Hur ser du på aktiv dödshjälp?» 66 \% tyckte att det skulle vara tillåtet, »men bara om personen är obotligt sjuk och inte 
har någon utsikt till förbättring och finner sitt lidande outhärdligt». $21 \%$ tyckte det skulle vara tillåtet »oavsett». $6 \%$ var tveksamma och $7 \%$ menade att det aldrig skulle vara tillåtet. Det var alltså 87 \% som var positiva till »dödshjälp». Det är oklart i vad mån de tillfrågade förstod skillnaden mellan dödshjälp och avbrytande av livsuppehållande behandling (»behandlingsbegränsning», se kap. 2). Denna undersökning föregicks av en debatt om en 31-årig totalförlamad kvinna som hade skrivit till Socialstyrelsen och vädjat om att läkarna skulle få söva henne och därefter stänga av respiratorn - alltså ett fall som handlade om behandlingsbegränsning, inte dödshjälp.

Opinionsinstitutet Ipsos MORI gjorde 2015 en undersökning i 15 länder där man ställde följande inledande fråga: "Tycker du att det skall vara lagligt eller inte för en doktor att assistera en patient som är 18 år eller äldre med att avsluta hans/hennes liv, om det är patientens önskan och under förutsättning att patienten är terminalt sjuk (med högst sex månaders förväntad överlevnadstid), är mentalt frisk och uttrycker en klar önskan att avsluta sitt liv?» Av de drygt 2200 svenskar som deltog ansåg $69 \%$ att det skulle vara lagligt och $18 \%$ menade att det inte skulle vara lagligt.

I slutet av 2017 gjorde KIT/Novus en undersökning med målgruppen svensk allmänhet 18-79 år (Olsson, 2017). Totalt genomfördes 1018 intervjuer. På frågan: »Vad är din inställning till legalisering av aktiv dödshjälp i Sverige, det vill säga att läkare på patientens begäran tillhandahåller en dödlig dos läkemedel som patienten själv kan ta i syfte att avsluta sitt liv?» svarade $61 \%$ att de var för en legalisering och $14 \%$ att de var emot. $25 \%$ svarade att de inte visste.

I samband med det tidigare nämnda Kramforsfallet gjorde Sifo en undersökning beställd av TV4 där frågan ställdes: »Tycker du att aktiv dödshjälp ska vara tillåten?» Av 1324 tillfrågade svarade 69 \% ja, 11 \% nej och resten vet ej. Följdfrågan till ja-sägarna gällde vilka som skulle få utföra dödshjälp. 88 \% ansåg att det skulle vara läkare, $23 \%$ annan sjukvårdspersonal, $28 \%$ anhörig, $6 \%$ annan och resten visste inte. Svarsalternativen visar att frågan gällde eutanasi och inte självmordsassistans.

När det gäller vårdprofessionen så säger Sveriges Läkarförbunds etiska regler: »Läkaren ska besinna vikten av att skydda människoliv och får 
aldrig vidta åtgärder som syftar till att påskynda döden». Svenska Läkaresällskapet, en ideell förening oberoende av Läkarförbundet, menar däremot att en eventuell legalisering av dödshjälp i första hand är en medborgarfråga och man säger sig vara varken för eller emot.

Den svenska läkarkårens inställning till dödshjälp har analyserats genom en studie (Lindblad, Löfmark \& Lynöe, 2008) där 1200 svenska läkare tillfrågades, med en svarsfrekvens på $74 \%$, om deras inställning till läkarassisterat självmord. $34 \%$ angav att de var positiva, $39 \%$ att de var negativa till läkarassisterat självmord och $25 \%$ var tveksamma.

\section{Status for dødshjelpsdebatten i 2020}

\subsection{Dødshjelpsdebatten i Danmark}

I Danmark som i andre lande debatteres det, om dødshjælp skal lovliggøres, det vil sige, om man uden retsforfølgelse og straf skal kunne tage et medmenneske (en patient) af dage, såfremt visse betingelser er opfyldt. Debatten forløber i bølger. Det Etiske Råd har gennem årene initieret debatten med sine redegørelser, se ovenfor. Det er netop en af rådets forpligtelser at være debatskabende. Men ikke sjældent starter en debat på baggrund af et enkelttilfælde, eventuelt en kendis, som omtales i medierne, og hvor enhver kan se stor lidelse og meningsløshed. Så kommer forslagene om at lovliggøre dødshjælp som et humant svar på lidelse. Eventuelt interviewes tilfældige mennesker på gaden (»vox-pop«). Derpå følger ikke sjældent hurtigt etablerede meningsmålinger, som i reglen på den givne baggrund viser et betydeligt flertal for lovliggørelse af dødshjælp.

I Danmark fik debatten om lovliggørelse af dødshjælp ny næring, da den ovenfor omtalte læge, Svend Lings, ved byretten og siden landsog højesteret blev dømt for sin medvirken til selvmord. Straffen blev i september 2019 skærpet i Højesteret til 6o dages fængsel, som imidlertid af hensyn til lægens alder blev gjort betinget. I december 2019 fastslog Lægeforeningens voldgiftsret, at Lings skulle ekskluderes som medlem af Lægeforeningen på grund af den grove tilsidesættelse af foreningens etiske principper. Debatten afspejler det polariserede syn på denne læge: 
Nogle (inklusive Lings selv) ser ham som en pioner og en humanistisk læge, som handler ud fra medfølelse med lidende mennesker. Andre ser ham som ansvarsløs og opmærksomhedssøgende og med unuancerede svar på eksistentielle problemer.

Fra tid til anden udtaler politikere sig om dødshjælp, og enkelte foreslår, at legalisering bør overvejes. Som i Norge gælder det især ungdomspolitikere. Det lille parti »Alternativet« har lovliggørelse af dødshjælp i sit partiprogram. I partiet »Det Radikale Venstre« fik et forslag om at optage lovliggørelse af dødshjælp i partiprogrammet ikke flertal ved partiets landsmøde i efteråret 2018. Der har ikke været nogen formelle lovforslag om indførelse af dødshjælp i Danmark. Fra 2018 har det været muligt at stille borgerforslag om emner, som Folketingets politikere skal behandle, hvis et forslag opnår et antal støtter fra mindst 50.000 borgere. Et sådant borgerforslag om indførelse af dødshjælp fra 2018 faldt til jorden, da det ikke opnåede et tilstrækkeligt antal underskrifter.

\subsection{Dødshjelpsdebatten i Norge}

Norge har aldri hatt noen bred politisk samfunnsdebatt om legalisering av dødshjelp. Men til stadighet kommer det utspill fra enkeltpolitikere, organisasjoner eller andre aktører, ofte i lys av en mediesak. Det fører til en kortvarig oppblussing av debatten, men uten at det har munnet ut $\mathrm{i}$ konkrete legaliseringsforslag. De mest konkrete framstøtene i norsk politikk var et representantforslag fra Fremskrittsparti-politikeren Fridtjof Frank Gundersen i 1998 (om utredning av dødshjelp) og det såkalte «professorforslaget» fra jussprofessorene Andenæs, Bratholm og Sejersted i 1992 om å benytte nødrettslovgivning som basis for å tillate dødshjelp. Dette tilsvarte måten dødshjelp ble legalisert på i Nederland. To av fem medlemmer i straffelovkommisjonen gikk inn for et slikt forslag, men det ble avvist av Stortingets justiskomité i 2005 (Førde, Materstvedt \& Syse, 2008, s. 426).

I 2009 vedtok Fremskrittspartiet, som hittil eneste stortingsparti, et mål om å tillate dødshjelp i sitt prinsipprogram. Men partiet har så langt ikke gjort noen alvorlige framstøt for å nå dette målet, til tross for at de var i regjering fra 2013 til 2020. 
De siste årene har flere ungdomspartier fra begge sider av det politiske spekteret gått inn for enten utredning eller legalisering av dødshjelp i Norge. Tilsvarende forslag har imidlertid blitt avvist i andre ungdomspartier, og «moderpartiene» har i stor grad svart at dødshjelp ikke er aktuell politikk for dem. I dag pågår det derfor ingen politisk debatt om legalisering av dødshjelp; tiden vil vise hva ungdomspolitikerne gjør når de overtar ansvaret.

\subsection{Dödshjälpsdebatten i Sverige}

Resultaten av opinionsundersökningar används som ett viktigt argument av dödshjälpens tillskyndare för att försöka övertyga politiker att dessa är ur fas med folkopinionen. Under åren har det gjorts upprepade försök att få tillsatt en parlamentarisk utredning i frågan, men utan framgång så här långt. Trots stundtals intensiv debatt har dödshjälp inte varit någon het politisk fråga och under lång tid var det endast Miljöpartiet som hade tagit beslut om att verka för att få till en offentlig utredning. Men under senhösten 2019 flammade debatten upp igen och tre andra partier ändrade sina positioner. Liberalerna beslöt att verka för en parlamentarisk utredning. Moderaterna och Sverigedemokraterna beslutade att tillsätta interna utredningar om dödshjälp i sina respektive partier. Denna utveckling har till stor del drivits på av inflytelserika förespråkare bland riksdagspolitikerna.

Men dödshjälpsförespråkarna är framför allt organiserade i Riksföreningen Rätten Till en Värdig Död (RTVD) som i början av 2016 lämnade in en promemoria till dåvarande sjukvårdsminister Gabriel Wikström (S) med uppmaningen att tillsätta en utredning. I sin skrivelse förordade RTVD ett dödshjälpsinstitut enligt Oregonmodellen, dvs. läkarassisterat självmord. Detta faktum att medverkan till självmord inte är straffbart i Sverige har medverkat till att förespråkarna rekommenderar Oregonmodellen. Man tänker sig att det skulle vara ganska enkelt att införa en sådan modell i Sverige eftersom brottsbalkens stadgar om mord och dråp inte behöver skrivas om. Det man föreslår i promemorian är en ändring i sjukvårdens regelsystem.

Förslaget avvisades av såväl Gabriel Wikström som hans efterträdare socialminister Annika Strandhäll (S). Båda ministrarna välkomnade 
däremot Statens medicinsk-etiska råds (Smer) vidare arbete med frågan, som under senhösten 2017 utmynnade i en kunskapssammanställning om dödshjälp med speciellt fokus på Oregonmodellen (Statens medicinsk-etiska råd, 2017). I rapporten, som kan sägas ha bildat en ny utgångspunkt i den svenska debatten, togs ingen ställning i sakfrågan och Smer uppger sig ha en neutral position.

Rapportens ambition är att ge faktaunderlag för en informerad debatt och den ger argument åt både förespråkare och opponenter. Båda sidor i debatten menar sig ha fått stöd för sin sak genom Smers rapport och debatten tycks fortsätta i samma hjulspår som tidigare (Statens medicinsk-etiska råd, 2018). Men en viktig slutsats som båda sidor bör kunna dra från rapporten är att man inte kan utesluta att »fel» människor har dött i tillämpningen av Oregons dödshjälpslag (se kap. 14) och att det är en öppen fråga om det överhuvudtaget är möjligt att konstruera en dödshjälpslag som helt kan förhindra oönskade dödsfall (se kap. 15).

I samband med det ovan nämnda Kramforsfallet har det uppstått en ny situation i debatten. Under de senaste åren har de tongivande dödshjälpstillskyndarna konsekvent förordat Oregonmodellen. De har framhållit att det bara ska gälla obotligt sjuka personer som har maximalt 6 månader kvar att leva och att dessa skulle kunna få ett dödligt preparat utskrivet av läkare för självadministration, det vill säga läkarassisterat självmord. Men under intervjuer i samband med Kramforsfallet har två av dessa framträdande förespråkare menat att det borde finnas regelverk på plats i Sverige som skulle ha möjliggjort laglig dödshjälp av den ME-sjuka kvinnan. Eftersom kvinnan varken var döende eller kapabel att ta sitt eget liv med assistans har dessa förespråkare därmed tillkännagivit att de önskar en modell som tillåter eutanasi av kroniskt sjuka.

\section{Hva kan vi lære av meningsmålinger om dødshjelp?}

I skandinaviske dødshjelpsdebatter vises det ofte til at befolkningsundersøkelser gir klare flertall for legalisering av dødshjelp. For mange er dette i seg selv et viktig argument for at dødshjelp bør bli tillatt. Når meningsmålingene får så stor betydning i debatten, blir det ekstra viktig 
å vurdere hva vi kan lære av dem. Vi vil derfor stille og kortfattet drøfte fire spørsmål om meningsmålinger: Hvem blir spurt? Hvilke spørsmål stilles? Hvordan skal svarene tolkes? Hvilke konsekvenser bør undersøkelsene få?

\subsection{Hvem blir spurt?}

Et fundamentalt valg i utformingen av en meningsmåling er hvem som skal spørres. I et spørsmål om hva som skal være lov i landet, er det åpenbart at alle med stemmerett også er meningsberettiget. Man sier gjerne at døden angår oss alle, men dødshjelp berører likevel noen grupper ekstra sterkt: De som er «kandidater» for dødshjelp, særlig alvorlig syke pasienter nær døden; og de som er ment å yte dødshjelpen: leger og eventuelt annet helsepersonell.

To sentrale temaer er derfor implisitte i dødshjelpsdebatten: Hvilke omstendigheter skal kunne berettige at en person kan få dødshjelp, og hvem skal i så fall yte dødshjelpen? Dette er samfunnsspørsmål, men samfunnsspørsmål som angår alvorlig syke pasienter og helsepersonell mer enn de fleste andre.

Vårt samfunn er preget av «ungdomsidealer», og man kan se for seg at unge mennesker har vanskelig for å se verdien i et liv preget av alderdomssvakhet, sviktende sanser og funksjonsnedsettelse. Er det da riktig å meningsmåle friske unge mennesker om hva de mener skal kunne skje med de eldre og syke?

Det er godt kjent blant fagfolk at mange pasienter endrer syn på dødshjelp når de gjennomgår alvorlig sykdom, kommer seg gjennom den første sjokkfasen og blir bedre kjent med egen tilstand og hva helsetjenesten har å tilby (Johansen, Høien, Kaasa, Loge \& Materstvedt, 2005; se også kap. 10). Mennesker har en sterk evne til å tilpasse seg nye situasjoner og livsbetingelser. Etter en tilpasningsfase kan de reorientere seg og finne mening og livskvalitet - selv i situasjoner de før ville ha karakterisert som «en skjebne verre enn døden». Det er vist at personer med funksjonshemninger gjerne vurderer egen livskvalitet høyere enn det utenforstående - også pårørende og helsepersonell - vurderer den til (Albrecht \& Devlieger, 1999). Mange har negative fordommer om hvordan alvorlig 
sykdom og død arter seg, og særlig sterkt er bildet av uutholdelig smerte. I hvilken grad er det fordommer om funksjonshemning og ulidelig lidelse ved livets slutt som kommer til syne i meningsmålinger om dødshjelp?

Videre kan det hevdes at legers langt mer skeptiske synspunkter burde veie spesielt tungt, all den tid det er de som vil få straffriheten for, men også belastningen med, å utføre dødshjelp (se kap. 9).

\subsection{Hvilke spørsmål stilles?}

I meningsmålinger om kompliserte bioetiske spørsmål som dødshjelp blir ordlyden ekstra viktig. Respondentene har ofte begrensede forkunnskaper om temaet, og reaksjonene kan påvirkes av små variasjoner i følelsesladde ord. Dette er ukontroversielt, og en del av dagligtalen: Når en pasient legges inn på sykehus med akutt hjerteinfarkt, har det betydning hvordan helsepersonellet ordlegger seg. De sier at «du er trygg nå», «vi skal undersøke deg grundig», «legen har gjort dette mange ganger». Ord er kommunikasjonshandlinger med tydelig effekt. Derfor betyr det mye hvilke ord vi velger, når vi spør befolkningen om deres syn på dødshjelp. Dette ble blant annet vist $\mathrm{i}$ en norsk studie som fant ulik grad av støtte til legalisering av dødshjelp, avhengig av hvordan spørsmålet ble formulert - henholdsvis i et positivt og et mer nøkternt/nøytralt lys (Magelssen et al., 2016; se også Parkinson et al., 2005). En dansk meningsmåling kan også tjene som eksempel. Der ble spørsmålet stilt som følger (Epinion, 2006):

I Holland har det siden 2001 været lovligt for praktiserende læger under visse omstændigheder at yde aktiv dødshjælp til alvorligt syge patienter, der lider ubærligt og ikke har nogen udsigt til forbedring. I Danmark diskuteres det i øjeblikket, om aktiv dødshjælp bør lovliggøres. Bør det efter din opfattelse være tilladt for læger at yde aktiv dødshjælp, hvis en alvorligt syg patient frivilligt og velovervejet anmoder om det?

Her presenteres respondenten for de to hovedargumentene for dødshjelp i selve spørsmålsstillingen, nemlig å unngå unødig lidelse og å respektere menneskets selvbestemmelse. Vilkårene «frivilligt» og «velovervejet» fungerer som «plussord» som kan lede respondenten i retning av å støtte påstanden. Motargumenter eller problematisering av argumenter 
og begreper er derimot fraværende i det respondenten blir presentert for. Det er sannsynlig at dette leder respondentene i retning av å uttrykke støtte til dødshjelp.

Dødshjelp betyr eutanasi eller assistert selvmord (kap. 2), men for noen forbindes begrepet også med adgang til behandlingsbegrensning. Det siste er særlig aktuelt i Finland, hvor uttrykket «kuolinapu» kan ha alle disse tre betydningene (kap. 4). Men også i de andre nordiske landene hersker det ofte forvirring om hva som menes med begrepene. Dersom spørsmålet i undersøkelsen ikke klart nok definerer hva man egentlig spør om - slik at også legfolk forstår hva som menes, og hvor viktige skillelinjer går - risikerer man at respondentene svarer på noe annet enn det man tror de svarer på.

En spørreundersøkelse fra New Zealand, hvor et dødshjelpsforslag skal til folkeavstemning i 2020, avdekket at misforståelser om dødshjelp og lovforslaget var utbredte (Curia, 2019). Flertallet trodde at forslaget ville medføre at pasienter kunne få nok medikamenter til å være fri fra smerte (62 \%), velge å ikke bli gjenopplivet (72\%) eller få slått av maskiner som holdt dem kunstig i live (74 \%). Det første er naturligvis lovlig og vidt utbredt. De to siste regnes som behandlingsbegrensning (se kap. 2) og er også allerede tillatt.

\subsection{Hvordan skal man tolke svarene?}

Spørreundersøkelser om dødshjelp henvender seg til mange mennesker og samler synspunktene deres i enkle kategorier. Det kan være «ja/nei/vet ikke», eller mer nyanserte kategorier. Respondenter som svarer «ja, helt sikkert», må man anta at virkelig er positive til legalisering av dødshjelp, og tilsvarende med de som klart er mot. Men hva med de som sier «delvis», «kanskje», «litt enig»? Folks holdninger til et så stort og komplisert spørsmål som dødshjelp er antakeligvis sammensatt og nyansert, trolig farget av en rekke faktorer, inkludert framstilling i medier, populærkultur og egne erfaringer med sykdom og død hos en selv eller hos nære pårørende.

Til forskjell fra dette handler spørsmålet om legalisering av dødshjelp om en dikotomi: Enten skal det være lov, eller så skal det være forbudt. 
Dersom det skal være tillatt, vil en rekke faktorer gjerne legges inn som avgrensninger og sikkerhetsmekanismer, men det er ikke gitt at disse samsvarer med betingelsene respondenten ønsker å støtte. I en folkeavstemning vil respondentene måtte bestemme seg, stemme for det ene eller det andre, eller avstå. Men i en spørreundersøkelse svarer man på et hypotetisk spørsmål, der man kan unne seg å svare litt ja og litt nei. Kommentarfeltene som ledsager mange meningsmålinger, viser nettopp dette: Mange av respondentene gir uttrykk for at de ser argumenter både for og mot, og det er ikke entydig hva de ville ha landet på.

\subsection{Hva bør politikerne gjøre?}

Ingen av de nordiske landene har direkte demokrati. Vi er representative demokratier der politikere stemmer på vegne av oss, og belønnes eller straffes av befolkningen i neste valg. Det er ingen automatikk i at politikere bør vedta de lovene befolkningen til enhver tid ønsker seg, selv om folkeviljen burde komme til uttrykk i lovverket. Mange hevder det utgjør et demokratisk problem og at politikerne er feige når de ikke vil tillate dødshjelp.

Dødshjelp er imidlertid ett eksempel på svært vanskelige spørsmål som det er krevende for legfolk å sette seg inn i og få full oversikt over. Det er nettopp i slike spørsmål man kan tenke seg at det representative demokratiet har sin styrke: Det er for dette vi velger politikere som kan gjøre den jobben for oss, ut fra et større og mer langsiktig perspektiv om hva som er bra for samfunnet som sådant.

Når folk flest i meningsmålingene blir spurt om de støtter legalisering av dødshjelp, er det naturlig at de ser for seg en situasjon der de selv eller deres kjære er nær døden og lider uutholdelig. Ville de ønske å ha dødshjelp som et tilgjengelig alternativ? Det er fullt forståelig at svaret for mange er «ja». Våre politikere må derimot stille seg et helt annet spørsmål når de konfronteres med dødshjelpstemaet: Er det mulig å lage en god dødshjelpslov der det er et gunstig forhold mellom nytte og risiko/skade, både for enkeltborgere og for samfunnet? Politikere som ønsker å omsette befolkningens vilje - uttrykt gjennom meningsmålinger - til praktisk lovverk, har en krevende oppgave: De må utforme lover, reguleringer og 
sikkerhetsmekanismer som gjør en eventuell dødshjelpslov entydig, rettferdig og forsvarlig (kap. 15).

\subsection{Konklusjon}

En lang rekke meningsmålinger i Skandinavia har vist et flertall for legalisering av dødshjelp. Det er dessuten en ikke ubetydelig minoritet blant leger og annet helsepersonell som stiller seg positive til legalisering - selv om få leger selv ville være villige til å utføre dødshjelp om det skulle bli tillatt. Befolkningsundersøkelsene må leses med omhu; et viktig spørsmål er om de stiller de relevante spørsmålene til de relevante gruppene. Tross aktiv dødshjelpsdebatt i samfunnet kan det råde forvirring om både begreper og fakta blant vanlige folk. Vår analyse viser at lovgiver ikke uten videre kan omsette meningsmålinger til praktisk politikk.

\section{Referanser}

Albrecht, G. L. \& Devlieger, P. J. (1999). The disability paradox: High quality of life against all odds. Social Science and Medicine, 48(8): 977-988.

Curia. (2019). Euthanasia issues poll November 2019. Hentet fra https://euthanasiadebate. org.nz/wp-content/uploads/2019/10/Poll-on-the-End-of-Life-Choice-Bill-

November-2019.pdf

Den norske legeforening. (2015). Etiske regler for leger.

Det Etiske Råd. (1996). Dødshjoelp? - en redegørelse.

Det Etiske Råd. (2004). Eutanasi - lovliggørelse af drab på begcering.

Det Etiske Råd. (2012). Det Etiske Råds udtalelse om eventuel lovliggørelse af aktiv dødshjoelp.

Det Etiske Råd. (2019, 9. december). Nuancér debatten om aktiv dødshjælp (kronik). Politiken, 2. sektion, s. 7-8.

Edblom, K. (2010, 20. mars). Majoriteten för aktiv dödshjälp. Aftonbladet. Hentet fra https://www.aftonbladet.se/nyheter/a/WL6oKk/majoriteten-for-aktiv-dodshjalp

Epinion. (2006). DR - Danskernes holdning til aktiv dødshjoelp. Hentet fra https:// www.dr.dk/NR/rdonlyres/FD8o1oBD-758E-4D27-8DC8-7oDA68128ED2/308795/ TabelrapportDRAktivd\%C3\%B8dshj\%C3\%A6lp.pdf

Etikkrådet for farmasøyter. (2010). Vedr. norske farmasøyters holdning til legeassistert selvmord. Hentet fra https://www.nfs.no/wp-content/uploads/2019/o2/Etikk_ Svar_pa_henvendelse_2010.pdf 
Fahlbeck, R. (2017). Barnmorskedomen - Politiken vann, juridiken förlorade. Juridisk Tidskrift, 2017/18(1), 218-227.

Funch, M. (2017, 1. juni). Læger siger massivt nej til aktiv dødshjælp. Kristeligt Dagblad.

Førde, R., Aasland, O. G. \& Falkum, E. (1997). The ethics of euthanasia - attitudes and practice among Norwegian physicians. Social Science and Medicine 45, 887-92.

Førde, R., Materstvedt, L. J. \& Syse, A. (2008). Scandinavia. I J. Griffiths, H. Weyers \& M. Adams (Red.), Euthanasia and Law in Europe (s. 425-442). Oxford: Hart Publishing.

Førde, R. \& Aasland, O. G. (2014). Are end-of-life practices in Norway in line with ethics and law? Acta Anaesthesiologica Scandinavica, 58(9), 1146-1150.

Gaasø, O. M., Rø, K. I., Bringedal, B. \& Magelssen, M. (2019). Legers holdninger til aktiv dødshjelp. Tidsskr nor legeforen, 139(1), 31-35. Hentet fra https://tidsskriftet. no/2019/o1/originalartikkel/legers-holdninger-til-aktiv-dodshjelp

Helsedirektoratet. (2013). Beslutningsprosesser ved begrensning av livsforlengende behandling. (IS-2091). Hentet fra https://helsedirektoratet.no/Lists/Publikasjoner/ Attachments/67/IS-2091-Beslutningsprosesser-ved-begrensning-avlivsforlengende-behandling.pdf

Holst, N. S. \& Adolphsen, C. (2017). Dødshjælp - rettigheder og pligter i forbindelse med behandlingsafvisning og behandlingsophør. Juristen (6), 217-24.

Husebø, S. (2009, 12. juni). En synders refleksjoner. Aftenposten. Hentet fra https:// www.aftenposten.no/meninger/i/416MG/En-synders-refleksjoner

Ispos MORI. (2015). Public attitudes to assisted dying. Hentet fra https://www.ipsos. com/ipsos-mori/en-uk/public-attitudes-assisted-dying

Johansen, S., Høien, J. C., Kaasa, S., Loge, J. H. \& Materstvedt, L. J. (2005). Attitudes towards, and wishes for, euthanasia in advanced cancer patients at a palliative medicine unit. Palliative Medicine, 19(6), 454-460.

Karlsson, M. (2011). End-of-life care and euthanasia: Attitudes of medical students and dying cancer patients. Akademisk avhandling, Karolinska Institutet.

Lindblad, A., Löfmark, R. \& Lynöe, N. (2008). Physician-assisted suicide: A survey of attitudes among Swedish physicians. Scandinavian Journal of Public Health, $36(7), 720-727$.

Magelssen, M., Pedersen, R. \& Førde, R. (2018) Hvordan arbeider klinisk etikkkomiteene? Tidsskr nor legeforen, 138, 134-137.

Magelssen, M., Supphellen, M., Nortvedt, P. \& Materstvedt, L. J. (2016). Attitudes towards assisted dying are influenced by question wording and order: A survey experiment. BMC Medical Ethics, 17 . Hentet fra https://bmcmedethics. biomedcentral.com/articles/10.1186/s12910-016-0107-3

Materstvedt, L., Ottesen, S., von Hofacker, S. \& Syse, A. (2019, 29. januar). Unødvendig lidelse kan unngås ved livets slutt. Dagens Medisin. 
Matzen, L. E., Ilvemark, J. \& Dahle, B. (2016). Questionnaire-based survey suggests that the majority of Danish geriatricians are against euthanasia. Danish Medical Journal, 63(2), A5187.

Norges Handikapforbund. (2019). Interessepolitisk program 2019-2021. Hentet fra https://nhf.no/wp-content/uploads/2019/11/NETT_intr-politisk-program-19-21_ NHF.pdf

Norsk Sykepleierforbund. (2011). Yrkesetiske retningslinjer for sykepleiere.

Olsson, E. (2017). Sex av tio vill legalisera dödshjälp - varför är politikerna så tysta? KIT.se. Hentet fra https://kit.se/2017/12/18/99509/sex-av-tio-vill-legaliseradodshjalp-varfor-ar-politikerna-sa-tysta/

Parkinson, L., Rainbird, K., Kerridge, I., Carter, G., Cavenagh, J., McPhee, J. \& Ravenscroft, P. (2005). Cancer patients' attitudes towards euthanasia and physician-assisted suicide: The influence of question wording and patients' own definitions on responses. Journal of Bioethical Inquiry 2(2), 82-9.

Statens medicinsk-etiska råd. (2017). Dödshjälp. En kunskapssammanställning. Hentet fra http://www.smer.se/rapporter/dodshjalp-en-kunskapssammanstallning/

Statens medicinsk-etiska råd. (2018). Svensk debatt efter publiceringen av Smers rapport om dödshjälp. Hentet fra http://www.smer.se/debatten-efterpubliceringen-av-smers-rapport-om-dodshjalp/

Sygeplejeetisk Råd. (2009). Aktiv dødshjælp - for eller imod. Hentet fra https://dsr. $\mathrm{dk} / \mathrm{ser} /$ holdnkinger/aktiv-doedshjaelp-for-eller-imod

\section{Ordforklaringer}

andningshämmande $(\mathrm{S})$ : respirationsdæmpende $(\mathrm{D}, \mathrm{N})$

anke $(\mathrm{N})$ : överklagande $(\mathrm{S})$

brottsbalken (S): straffeloven (D, N)

brottslig (S): kriminelt (D, N)

följdfrågan (S): opfølgingsspørgsmålet (D), oppfølgningsspørsmålet (N)

fördolda (S): skjulte (D, N)

förespråkare (S): forkjempere (N), fortalere (D)

indgift (D): tilförsel (S), tilførsel (N)

förordade (S): foreslo(g) (D, N)

legitimation $(\mathrm{S})$ : autorisation $(\mathrm{D}, \mathrm{N})$

meningsmålinger (N/D): opinionsmätningar $(\mathrm{S})$

nævn (D): nemnd (N), nämnd (S)

om lag $(\mathrm{N})$ : circa $(\mathrm{D})$, ungefär $(\mathrm{S})$

omhu (N): försiktighet (S), forsigtighed (D)

ordskiftet $(\mathrm{N})$ : debatten $(\mathrm{D}, \mathrm{S})$ 
samvetsskäl (S): samvittighedsgrunde (D), samvittighetsgrunner (N)

spridd (S): udbredt (D, N)

stadgar $(\mathrm{S})$ : fastslår $(\mathrm{D}, \mathrm{N})$

stundtals (S): til tider $(\mathrm{D}, \mathrm{N})$

sundhedsperson $(\mathrm{D})$ : vårdpersonal $(\mathrm{S})$, helsepersonell $(\mathrm{N})$

Sundhedsstyrelsen (D): Socialstyrelsen (S), Helsedirektoratet (N)

syfte (S): formål $(\mathrm{N})$, hensigt $(\mathrm{D})$

så langt $(\mathrm{N})$ : så långt $(\mathrm{S})$, indtil videre $(\mathrm{D})$

tillfrågade $(\mathrm{S})$ : respondentene $(\mathrm{D}, \mathrm{N})$

tillhandahåller (S): yder/yter, bringer til veje/veie $(\mathrm{D}, \mathrm{N})$

tillämpningen $(\mathrm{S})$ : anvendelsen $(\mathrm{D}, \mathrm{N})$

totalförlamad (S): totalt lammet $(\mathrm{D}, \mathrm{N})$

uhyre (D): mycket (S), svært (N)

vädjat (S): appelleret $(\mathrm{D}, \mathrm{N})$

åtgärder (S): tiltag (D), tiltak (N)

åsiktsutbytet (S): meningsudvekslingen (D, N) 



\title{
Dödshjälpsdebatten i Finland
}

\section{Kalle Mäki}

\author{
Pihlajalinna Koskiklinikka, Tampere
}

\begin{abstract}
The citizens' initiative to legalise euthanasia was addressed in the Finnish Parliament in 2017. The Parliament rejected the initiative and appointed an expert group to investigate the need for legislation regarding end-of-life care and the need for euthanasia. Thus, the debate continues. This chapter provides an overview of the public debate and the political process associated with the citizens' initiative. The initiative is critically examined on the basis of expert opinions requested by the Parliament's Social and Health Committee. In a vote, the MPs rejected the initiative. One of the central arguments has been that it is not appropriate to legalise euthanasia when end-of-life care is not sufficiently developed in Finland. From many quarters, opinions were raised against the legalisation of euthanasia, promoting support for legislation on end-of-life care instead.
\end{abstract}

Keywords: assisted dying, euthanasia, Finland, legalisation, palliative care

Finlands riksdag har varit det första parlamentet i Norden att behandla ett initiativ om eutanasi. Processen som följt visar hur mångsidig frågan om eutanasi egentligen är. Här beskrivs bakgrunden till medborgarinitiativet om eutanasi, debatten kring initiativet och behandlingen i riksdagen. Argumenten för och mot initiativet behandlas kritiskt mot bakgrund av sakkunnigutlåtanden som riksdagens social- och hälsovårdsutskott begärde av olika parter. Skribenten har själv deltagit i medborgardebatten och bidragit med material till sakkunnigutlåtanden.

Sitering av denne artikkelen: Mäki, K. (2020). Dödshjälpsdebatten i Finland. I M. A. Horn, D. J. H. Kleiven \& M. Magelssen (Red.), Dødshjelp i Norden? Etikk, klinikk og politikk (Kap. 4, s. 75-102). Oslo: Cappelen Damm Akademisk. https://doi.org/10.23865/noasp.96.ch4.

Lisens: CC BY 4.0. 


\section{Vad betyder det att tala om dödshjälp - debatten i Finland}

\section{Brist på lag om livets slutskede}

Debatten om dödshjälp står i nära förbindelse med vård i livets slutskede. Finland har varit ett genomsnittligt land i Europa när det gäller nivån av palliativ vård och vård i livets slutskede (Smets et al., 2018). Detsamma har varit fallet med undervisningen i palliativ medicin (Carrasco et al., 2015). Mot denna bakgrund är det förståeligt att ingalunda alla som skulle behöva det har fått vård i livets slutskede av bästa möjliga kvalitet, även om det finländska hälso- och sjukvårdssystemet i allmänhet står på god europeisk nivå. Kravet att tillåta och legalisera eutanasi har utgått från enskilda personers erfarenheter av bristerna i vården och från den övergripande trenden att öka individens autonomi.

Eutanasi är olagligt i Finland (Strafflag 39/1889), men det är inte olagligt att hjälpa någon att begå självmord. Juridisk expertis anser emellertid att om någon som arbetar inom hälsovården bidrog till assisterat självmord skulle den personen sannolikt straffas, men några prejudikat finns inte.

Trots att finsk lag inte ger någon entydig definition av begreppet dödshjälp ska man straffas enligt strafflag 39/1889 kap. 21 \$1-3 som dråp, mord eller dråp under förmildrande omständigheter. För de här ska dömas till fängelse i minst fyra år och högst på livstid med möjlighet till reduktion. Om man estimerar dödshjälp, till exempel läkarassisterat självmord, som dödsvållande eller grovt dödsvållande, då ska dömas enligt strafflag kap. $21 \$ 8-9$ till böter eller till fängelse i högst sex år.

Finland saknar lagstiftning om vård i livets slutskede. Inom hälsovården vägleds verksamheten i regel med riktlinjer och rekommendationer, inte detaljerad lagstiftning. Social- och hälsovårdsministeriet (Pihlainen, 2010) och den riksomfattande etiska delegationen inom social- och hälsovården ETENE har tidigare utfärdat rekommendationer för vård i livets slutskede och etiska rekommendationer (ETENE, 2001, 2003, 2011 och 2012). Europarådets rekommendationer (Council of Europe, 2003) har också godkänts. Medicinsk vägledning har getts inom ramen för en nationell behandlingsrekommendation God medicinsk praxis (Finska Läkarföreningen Duodecim, 2019), och Finlands Läkarförbund har 
utfärdat etiska rekommendationer (Saarni, Kattelus \& Nummi, 2013). Lagen om yrkesutbildade personer inom hälso- och sjukvården 559/1994 (yrkesetiska skyldigheter $\$ 15$ ) definierar vårdpersonalens etik.

Finland var ett föregångsland i Europa när patientens rättigheter fastställdes i lagen om patientens ställning och rättigheter 785/1992. Lagens huvudidé är respekt för patientens självständighet. Den stadgar att »vården skall ordnas och patienten bemötas så att hans människovärde inte kränks och att hans övertygelse och integritet respekteras». Lagen stadgar också att »vården och behandlingen skall ges i samförstånd med patienten». Patienten har rätt att vägra att ta emot vård eller behandling, men inte rätt att kräva viss vård.

\section{Uppfattningar och debatten om dödshjälp}

Befolkningens uppfattningar om eutanasi, läkarassisterat självmord och vård i livets slutskede bygger troligen till stor del på vad som finns i media. Flera berättelser finns publicerade som låter förstå att eutanasi skulle vara berättigat. Man har fått ta del av människors erfarenheter, om hur släktingar eller vänner har lidit alldeles för mycket i livets slutskede och hur svårt eller omöjligt det är för vårdpersonalen att lindra den döendes smärtor tillräckligt. I Finland har föreningen Exitus lobbat för lagstiftning som skulle godkänna eutanasi.

Oklar terminologi i offentliga media är ett problem. Man har lämnat odefinierat vad som avses med dödshjälp (kuolinapu på finska). Oftast betyder det eutanasi eller assisterat självmord. Men ordet kuolinapu har också en tredje, annorlunda mening: att avstå från att ge vård som inte längre är till nytta för patienten utan som endast orsakar mer lidande då patientens liv förlängs (»behandlingsbegränsning»; se kap. 2). Då inväntas döden som ett naturligt förlopp utan att någon genom någon särskild handling skulle orsaka den. I en ordbok utgiven av Institutet för de inhemska språken ges ordet kuolinapu (dödshjälp) endast den här tredje meningen.

Samma ord kan alltså innebära helt olika handlingar med helt olika etiska värden. Det finns en väsentlig etisk skillnad mellan att låta döden komma och att avsiktligt orsaka döden (se kap. 2). Därför är det viktigt 
att alltid definiera vad man avser när man talar om dödshjälp. Finlands Läkarförbund (Mäki, 2017) och ETENE rekommenderar användningen av exakta termer, såsom eutanasi, läkarassisterat självmord och att avstå från vård. Också i riksdagen har man uttryckt dubier över hur man egentligen förstår varandra i diskussioner.

Dubierna har varit befogade, särskilt då enkäter gjorts där de olika betydelserna av ordet dödshjälp (kuolinapu) inte fastställts entydigt. De som svarat på enkäterna har givetvis utgått från hur de själva förstått ordet, och det har slutligen blivit oklart vad som egentligen avsetts (Natri, 2016). Detta har troligen lett till att bilden av befolkningens åsikter har förvrängts och blivit oriktig. Enligt dessa resultat skulle mycket över hälften av folket stödja dödshjälp.

År 2003 ansåg 29 \% av läkarna i Finland att eutanasi borde legaliseras, år 2013 var andelen $46 \%$. Trots detta har andelen läkare som själva skulle vara villiga att genomföra eutanasi inte ändrats särskilt: från $21 \% 2003$ till 23 \% 2013 (Louhiala, Enkovaara, Halila, Pälve \& Vänskä, 2015). Finlands Läkarförbund utredde vad läkare som vårdar döende patienter anser om eutanasi och om vården i livets slutskede. Utredningen visade att $64 \%$ var emot en lag om eutanasi och bara 17 \% för; 59 \% skulle inte godkänna lagstiftning där det skulle vara tillåtet för en läkare att hjälpa någon att begå självmord och bara $15 \%$ skulle godkänna en sådan lag. Däremot önskade 71 \% av läkarna en lag om vård i livets slutskede. Dessa siffror återspeglar åsikterna hos dem som känner patienternas lidanden och verkligen förstår vilka möjligheter god vård har att erbjuda (Finlands Läkarförbund, 2017a).

Man har frågat riksdagskandidater före valet år 2015 om deras åsikter. Bland de invalda till riksdagen svarade 119 av 200 »ja» på huruvida de anser att "en patient som lider av en obotlig sjukdom skulle ha rätt till assisterad död» (Sauli, 2016). Resultatet är märkvärdigt såtillvida att termen »assisterad död» inte skiljer mellan eutanasi, assisterat självmord eller att avstå från onödig vård. Ändå blev rubriken i media: »De flesta riksdagsledamöterna accepterar eutanasi» och detta resultat har använts i debatten som ett stöd för eutanasi.

Det har varit TV-diskussioner och debatter. Många böcker emot (bl.a. Pöyhiä, Reinikainen \& Tasmuth, 2014; Räsänen, 2017) och för eutanasi (bl.a. Seppänen \& Taipale, 2013) och böcker som presenterar båda åsikter 
(bl.a. Kotila, 1995) har publicerats. Det är anmärkningsvärt att den tidigare ledande läkaren för Terhokoti hospice i Helsingfors började tala för legalisering av eutanasi år 2012 (Hänninen, 2012).

Finlands Läkarförbund har framfört sina åsikter om eutanasi och vård i livets slutskede i boken Läkaretik som utgetts av förbundets etiska delegation. Världsläkarförbundet (World Medical Association, WMA) förhåller sig avvisande mot eutanasi (WMA, 2002 (rev. 2013), 2015 och 2019) och Finlands Läkarförbund uttrycker samma åsikt. Läkarförbundet anser att deltagande i aktivt avlivande av en patient, även om det sker på patientens begäran, strider mot läkaretiken och grundläggande etiska värden (Saarni et al., 2013).

\section{Medborgarinitiativet om eutanasi}

\section{Eutanasiinitiativets innehåll}

Ett medborgarinitiativ kan tas upp till behandling vid riksdagen om minst 50000 personer stöder initiativet inom loppet av sex månader. Fyra medborgarinitiativ har lagts fram för att legalisera eutanasi. Endast det fjärde initiativet togs upp i riksdagens plenum. Två f.d. riksdagsmän, Esko Seppänen och Iiro Viinanen, gjorde i november 2016 ett medborgarinitiativ med rubriken Motion om eutanasi för en god död. Initiativet stöddes av 63078 medborgare (Medborgarinitiativ.fi, 2016). Båda initiativtagarna hade personliga erfarenheter av en kär person som lidit mycket i livets slutskede.

I initiativet föreslås att riksdagen vidtar åtgärder för att legalisera eutanasin i Finland. Man motiverar initiativet bland annat med dessa ord: "En lag om eutanasi behövs som ett kompletterande alternativ i livets slutskede för dem av våra medmänniskor som för sitt outhärdliga lidande inte kan få lindring ens av en god palliativ vård.» Här ingår två huvudargument: patientens autonomi att välja och antagandet att det finns sådana lidanden som är outhärdliga. Initiativet innehåller inte förslag till slutlig lagtext utan snarast styrlinjer för lagstiftningen. I initiativet föreslås också: »Vid sidan av att det stiftas en lag är det viktigt att sörja för att kommunerna och/eller sjukvårdsdistrikten åläggs att ordna adekvat 
palliativ vård och terminalvård av hög kvalitet och att sådan vård står till buds i hela Finland.»

Anmärkningsvärt är att initiativet inte presenterar någon exakt definition av vad eutanasi är. Man beskriver endast att det är frågan om god död och att läkaren ska utföra eutanasi korrekt. Det skulle ha varit saklig information att ange den korrekta medicinska definitionen: Eutanasi betyder att »en läkare avsiktligt tar livet av en patient på dennes upprepade, av fri vilja och med rättslig handlingsförmåga, framställda begäran» (Saarni et al., 2013; se också kap. 2).

Initiativet förutsätter att läkaren ska utföra eutanasin, när vissa premisser är uppfyllda. Man säger ingenting om assisterat självmord. Eutanasiinitiativet framställer följande premisser för att eutanasi ska kunna utföras (direkt citat):

- Patienten har outhärdliga fysiska och/eller psykiska symptom, smärtor och lidanden som inte går att lindra väsentligt ens med en god terminal- eller palliativ vård och medicinska åtgärder.

- Patienten lider av en obotlig sjukdom som leder till döden som kommer att inträffa inom en nära framtid också utan eutanasi. Utgående från en medicinsk bedömning är patientens tillstånd hopplöst, utan utsikter att förbättras.

- Patienten är förmögen att vidta rättshandlingar, myndig och kognitivt kompetent.

- Patienten har av en läkare blivit informerad om sitt tillstånd, prognosen för sjukdomsförloppet och tillbudsstående vårdalternativ.

- Patienten har själv av fri vilja, efter moget övervägande och upprepade gånger framställt en begäran om eutanasi och beslutet har inte tillkommit genom yttre påtryckningar.

- Läkaren har med sin patient flera gånger samtalat om dennes begäran om eutanasi och blivit övertygad om att patientens önskan är bestående.

- Läkaren och patienten är överens om att övriga meningsfulla alternativ saknas för patienten.

- Läkaren är övertygad om att patienten inte lider av en psykiatrisk sjukdom som skulle försvaga dennes omdömesförmåga. En 
eventuell klinisk depression måste alltid skötas, innan ett beslut om eutanasi får göras.

- Läkaren har konsulterat åtminstone en opartisk läkare, som också själv måste träffa patienten och göra en bedömning av denne.

- Läkaren utför eutanasin korrekt, är själv närvarande tills döden inträtt och är därefter skyldig att göra en anmälan om utförd eutanasi till det övervakningsorgan som bör inrättas och för vilket han noggrant skall redogöra för de skäl som motiverat beslutet om eutanasi, verkställande av beslutet samt övriga uppgifter om fallet i enlighet med vad i lag närmare föreskrivs.

- Läkare eller vårdpersonal kan inte föreskrivas skyldighet att delta i utförande av eutanasi. Om en läkare inte vill gå med på att utföra begärd eutanasi, skall han hänvisa patienten till någon läkare som har beredskap att utföra eutanasi då fastställda kriterier uppfylls.

I offentligheten har ett otal artiklar och uppsatser skrivits som varit gynnsamt inställda till eutanasi och där man vill att riksdagen skulle stödja initiativet. En av de mest uppmärksammande artiklarna var artikeln i en kvällstidning om gossen Eino. Eino fick hjärnblödning och hamnade i koma. Specialister försökte på många sätt rädda pojken, men slutligen var han i ett vegetativt tillstånd. Då önskade hans pappa, som också var läkare, att Eino skulle få dödshjälp (Appelsin, 2016).

Efter artikeln om Eino fick initiativet ytterligare omkring 15 ooo stödförklaringar och därigenom tillräckligt stöd för att tas upp till behandling. Men märkvärdigt är att initiativet inte godkänner eutanasi för barn och också förutsätter att begäran om eutanasi sker av en person som har rättslig handlingsförmåga, vilket alltså inte kan gälla för barn. Slutsatsen blir därför att artikeln måste ha påverkat människors känslor vilket ledde till att de gav initiativet sitt stöd. Detta stöd skulle dock inte alls ha gällt gossen Eino.

\section{Eutanasiinitiativet i riksdagen}

Medborgarinitiativet om eutanasi togs upp till riksdagsbehandling i februari 2017 (Riksdagen, 2017a). Riksdagen diskuterade första gången medborgarinitiativet i mars 2017 och remitterade ärendet till social- och 
hälsovårdsutskottet för betänkande. Diskussionen var mycket intressant och tog nästan 6 timmar. Det var en överraskning att riksdagsledamöterna talade mer om vård i livets slutskede än om initiativet till eutanasi. Flera riksdagsledamöter tog istället för stöd till eutanasi initiativ till behov av ny lagsstiftning för att förbättra vården i livets slut. Riksdagsledamöter från fem partier presenterade sådana motioner, bland annat från de fyra största partierna i riksdagen (Riksdagen, 2017b; Hakala, 2018).

Riksdagsbibliotekets experter brukar sammanställa informationspaket för centrala lagstiftningsprojekt. Informationspaketet om eutanasi och vården i livets slutskede blev en mycket mångsidig öppen källa som finns tillgänglig för alla (Hakala, 2018).

Riksdagens social- och hälsovårdsutskott började behandla initiativet i november 2017. Initialt hade utskottet ett öppet möte, där initiativtagare (Lax, 2017) och några sakkunniga hördes. Efter det första mötet hörde utskottet flera sakkunniga, såväl specialister som organisationer. På uppdrag av utskottet gavs utlåtanden bland annat av Finlands Läkarförbund, flera läkare och några jurister, forskare inom palliativ vård, föreningen för palliativ medicin i Finland, sjukhussjälavården i evangelisk-lutherska kyrkan i Finland och några andra organisationer som har att göra med svårt sjuka patienter, samt av föreningen Exitus. Tillsammans fick utskottet 34 utlåtanden och de innehåller de viktigaste argumenten för och emot eutanasi (Riksdagen, 2018).

Utskottet lämnade sitt övervägande och utgav förslag till beslut enligt vilket riksdagen förkastar förslaget $i$ medborgarinitiativet. Utskottet utgav också ett förslag till uttalande:

Riksdagen förutsätter att statsrådet tillsätter en brett sammansatt expertgrupp för att utreda behovet av lagstiftning om god vård i livets slutskede, självbestämmanderätten samt vård i livets slutskede och eutanasi och att statsrådet vid behov och utifrån utredningen lämnar förslag till lagstiftningsändringar till riksdagen. (Social- och hälsovårdsutskottet, 2018)

Riksdagen bestämde 6.4.2018 enligt utskottets förslag: rösterna föll 129 för och 60 emot. Då utskottets förslag till beslut var att medborgarinitiativets förslag skulle förkastas diskuterade grundlagsutskottet inte initiativet och gjorde inte heller några överväganden i frågan. 


\section{Händelser då eutanasiinitiativet behandlades i riksdagen}

\section{Palliativ vård och vård i livets slutskede utvecklas}

Viktiga händelser inträffade vid tiden för social- och hälsovårdsutskottets överväganden i eutanasifrågan. ETENE gjorde en ny utredning om eutanasi och vård i livets slutskede i september 2017. Man skulle först bygga ut vårdsystemet så att den palliativa vården och vården i livets slutskede skulle ligga på en tillräckligt hög nivå och bli tillgängliga för alla behövande. ETENE menade att det endast efter detta är möjligt att bedöma hur många patienter som ännu lider exceptionellt mycket och huruvida det behövs en särskild lag för sådana situationer (ETENE, 2017).

Social- och hälsovårdsministeriet (SHM) tillsatte en specialistgrupp som lämnade sin rekommendation gällande palliativ vård och vård $i$ livets slutskede. Rekommendationen beskriver hur organisationen kring den palliativa vården skulle byggas upp inom riket (Saarto et al., 2017a). Statsrådets förordning om arbetsfördelning och centralisering av vissa uppgifter inom den specialiserade sjukvården 582/2017 trädde i kraft i början av år 2018. Denna förordning stadgar vilka vårdorganisationer $\mathrm{i}$ Finland som har ansvar för att organisera palliativ vård och vård i livets slutskede. Den finländska vetenskapliga organisationen för läkare, Finska Läkarföreningen Duodecim, utgav nya God medicinsk praxis - rekommendationer för palliativ vård och vård i livets slutskede i februari 2018 (Finska Läkarföreningen Duodecim, 2018). Allt detta visar att Finland har tagit ett nytt steg i synen på palliativ vård och vård i livets slutskede. Det tar tid innan alla goda planer har förverkligats.

\section{Diskussioner om eutanasi och palliativ vård}

Medan riksdagen övervägde medborgarinitiativet för att legalisera eutanasi, pågick en livlig offentlig debatt kring eutanasifrågan. En hel del artiklar och diskussionsprogram var positivt inställda till eutanasi, bland annat i Finlands största dagstidning Helsingin Sanomat. Även den största svenskspråkiga dagstidningen Hufvudstadsbladet publicerade en rad positiva artiklar om eutanasi. 
Finlands Läkarförbund anordnade en diskussionsturné om vård i livets slutskede vid alla fem universitet i Finland med en medicinsk fakultet. Föreläsarna var specialistläkare. Pressen inbjöds och skrev rätt mycket om ämnet (Finlands Läkarförbund, 2017b). Diskussionsturnén var en utmärkt möjlighet för Finlands Läkarförbund att för medborgarna beskriva vad eutanasi är och innebär och varför förbundet är negativt inställt till eutanasi.

Flera uttalanden från olika organisationer skickades till riksdagen och man gjorde också flera besök i riksdagen. Nordens första hospice Pirkanmaan Hoitokoti gav också ett uttalande baserat på deras mångåriga erfarenhet att med god vård i livets slutskede försvinner önskemål om eutanasi (2017). God vård betyder lämplig medicinsk behandling, en lyssnande medmänniska samt rätt avmätt psykologiskt, socialt, existentiellt och andligt stöd (se också kap. 10). Hospicet anser att det inte finns behov för eutanasi, men däremot nog för bättre lagstiftning som stöd för vård i livets slutskede och för bättre utbildning för vårdpersonalen.

Specialistläkare vid palliativa avdelningar på universitetssjukhusen utkom med en gemensam skrivelse som skickades till riksdagen. Denna skrivelse var ett av de mest inflytelserika utlåtandena då riksdagsledamöternas hade sin första debatt om eutanasi. Utlåtandet gick ut på att eutanasi inte är den rätta lösningen för lindring i livets slutskede. Istället bör en vederhäftig lagstiftning om vård i livets slutskede samt ordentlig utbildning i palliativ vård fås till stånd (Saarto, Lehto, Rahko, Hirvonen \& Tyynelä-Korhonen, 2017b).

\section{Argumenten i den finska eutanasidebatten Premisserna i medborgarinitiativet om eutanasi}

Kriterierna i eutanasiinitiativet har beskrivits ovan. En närmare kritisk genomgång av argumentationen är av värde, inte minst för att kasta en blick på hur argumenten i expertutlåtanden kolliderar med varandra.

Initiativet innehåller förhandskriterier för eutanasi, varav många är svåra att definiera. Initiativet berör i huvudsak mänskliga rättigheter, social etik, medicinsk etik, patientsäkerhet och frågan om vilka medicinska möjligheter som finns för att lindra lidande och att behandla patienten i slutet 
av livet. Initiativet i sig tar inte upp juridiska frågor och antar att de kan lösas, även om man kan säga att initiativet strider mot befintlig lagstiftning (Strafflag 39/1889 kap. 21). När det gäller argumentation är det viktigt att klargöra det exakta innehållet i koncepten som ingår i debatten.

Många viktiga argument ingår i sakkunnigutlåtandena som riksdagens social- och hälsovårdsutskott erhållit. I det följande belyses kort särskilt viktiga idéer och argument som framförts i dessa sakkunnigutlåtanden och i den finska debatten.

\section{Grundläggande argument}

Initiativet att legalisera eutanasi bygger på två grundläggande argument. För det första är tanken bakom initiativet att man borde kunna bestämma dagen för sin död, vilket kan motiveras av individens autonomi. För det andra innehåller initiativet tanken att det existerar oacceptabelt lidande som inte kan lindras väsentligt av de tillgängliga metoderna för palliativ vård och vård i livets slutskede.

\section{Mänskliga rättigheter och social etik}

Vårt samhälle bygger på allmänt erkända grundrättigheter som ingår i internationella deklarationer, bland annat FN:s deklaration och Europakonventionen om mänskliga rättigheter. Respekt för mänskligt liv och rätten till livet är grundläggande, lagstadgade rättigheter för alla medlemmar i samhället. Grundläggande rättigheter kan inte avyttras, inte ens om vederbörande självmant skulle vilja det. Rätten till liv utgör grunden för andra mänskliga rättigheter och är därför den mest grundläggande mänskliga rättigheten. Kontrakt som bryter mot våra grundläggande rättigheter är olagliga även om parterna som ingått dem skulle samtycka till kontraktsbrott. Våra grundläggande rättigheter är samhällsbaserade, vilket innebär att självbestämmanderätten inte kan betraktas som främsta rätt och därför kan den inte undantränga andra grundläggande rättigheter (Hallamaa, 2017a, 2017b).

I konflikt med dessa betraktelser beskriver medborgarinitiativet självbestämmanderätten som en rätt som kan komma före de andra mänskliga 
rättigheterna. Individens liv är skyddat i Finlands grundlag 731/1999 $\$ 7$ och $\$$ 22. Eutanasiinitiativet skulle ta bort skydden, varför det syns omöjligt att realisera om man följer grundlagen. Eutanasi skulle innebära en grundläggande förändring av den sociala etiken om den gav samhället rätten att avsluta människoliv och skapa ett system som omfattade en skyldighet att göra det på individens begäran. Europarådet har fördömt eutanasi och förkastat legitimiteten med sådana vårdtestamenten som tillåter eutanasi (Council of Europe, 2012) och särskilt fördömt eutanasi på barn (Council of Europe, 2014).

Europeiska domstolen för de mänskliga rättigheterna har hävdat att »rätten att dö» inte kan härledas från de grundläggande rättigheterna; samhället har ingen skyldighet att acceptera individens önskan att dö genom av samhället godkänd eutanasi (Pretty v. United Kingdom, 2002). Domstolen har konstaterat (Haas mot Schweiz, 2011) att det finns olika åsikter på nationell nivå om hur man ska betona skyddet för individens liv och individens önskan att sluta sitt liv (European court of human rights, 2019). Dessa uttalanden gör inte eutanasi acceptabel eller berättigad. I sina expertutlåtanden till social- och hälsokommittén tolkar två advokater emellertid att artikel 2 i Europakonventionen inte hindrar medlemsstaterna från att införa eutanasilagstiftning (Lahti, 2017; Lehtonen, 2018).

Av många goda skäl begränsar samhället individens autonomi på många sätt. Det visar att självbestämmanderätten inte automatiskt kommer först i jämförelse med andra rättigheter. Man har därför ur människorättsperspektiv ifrågasatt att motivera eutanasi på ett hållbart sätt primärt av individens självbestämmanderätt.

\section{»Outhärdligt lidande»}

Medborgarinitiativet bygger på tanken om »outhärdliga fysiska och/eller psykiska symtom, smärtor och lidanden som inte går att lindra väsentligt ens med en god terminalvård eller palliativ vård och medicinska åtgärder». Vad är dessa symtom, smärtor och lidanden och vad är »outhärdligt lidande»? I medborgarinitiativet finns ingen fastställd definition av dessa begrepp. Lidande kan bedömas objektivt i viss utsträckning, men dess 
väsentliga dimension är en subjektiv upplevelse. Det är svårt att fastställa utvärderingskriterier för denna individuella erfarenhet (Tyynelä-Korhonen, 2018). Enligt sina expertutlåtanden anser initiativtagarna att »outhärdligt lidande» endast kan definieras av patienten själv (Lax, 2017). Detta står dock i kontrast med läkarens skyldighet att bedöma patientens tillstånd. Initiativet grundar sig i hög grad på begreppet »outhärdligt lidande», men eftersom det är en odefinierad term är det tveksamt om lagen kan byggas på denna term på så tryggt sätt som vårt samhälle förutsätter. I Benelux-länderna har man ändå gjort sådana lagar och de ger jämförelsepunkter (se kap. 13).

\section{»Väsentlig lindring»}

Det andra kriteriet kräver att detta outhärdliga lidande inte kan lindras väsentligt. Väsentlig lindring har inte heller definierats i initiativet, men initiativtagarna anser att en del patienter inte kan få »väsentlig lindring» (Hänninen, 2018; Seppänen, 2018; Lax, 2017). Om man tittar på de nuvarande metoderna för palliativ vård och vård i livets slutskede, kan man säga att smärtan kan kontrolleras ganska väl och att smärta inte är ett olösligt problem enligt palliativvårdsläkare (se kap. 10). På samma sätt finns det goda lindrande behandlingar för andra fysiska symtom. Den sista och mycket effektiva behandlingsformen är palliativ sedering, där patientens medvetenhet gradvis minskas medicinskt i tillräcklig nivå intermittent eller oavbrutet så att patienten inte lider vid slutet av livet. Nuvarande exakta behandlingsrekommendationer för genomförande av palliativ sedering förkortar inte livet (Saarto, 2017; Pöyhiä, 2018).

I studier från Oregon har man funnit att orsaken till begäran om assisterat självmord är rädslan för förlusten av livskontroll och värdighet och känslan av att vara en börda - alltså inte i första hand rädsla för smärta (se kap. 14; Saarto, 2017; Hänninen, 2018). Enligt expertutlåtandet av författarna till medborgarinitiativet är eutanasi berättigad genom att det finns människor som på grund av sin sjukdom är rädda för livets slut, och kännedom om möjligheten till eutanasi skulle hjälpa dessa människor att känna sig trygga (Lax, 2017). Initiativets författare 
åberopar således folkets farhågor som grunden för eutanasi. Detta skiljer sig från de kriterier som anges i själva initiativet. Inte heller räknar man med att det också kunde finnas människor som är rädda för att möjligheten till eutanasi existerade (Finlands Kristna Läkarförbund (FKL), 2018).

Bra vård i livets slutskede stöder människans egen livskontroll. I hospicevård har man funnit att många farhågor och önskemål om eutanasi försvunnit då miljön är trygg och human och tar hänsyn till de psykologiska, sociala och existentiella dimensionerna hos den döende (FKL, 2018; Pöyhiä, 2018; se också kap. 10). Vården utvecklas hela tiden och redan med nuvarande metoder fås betydande lindring till stånd hos en döende patient som lider av smärta och andra fysiska och psykiska symtom (Saarto, 2017; Pöyhiä, 2018). När det finns väsentlig lindring att tillgå försvinner den mest centrala motiveringen för eutanasi (Nuotio, 2018).

\section{»Döden som kommer att inträffa inom en nära framtid»}

Medborgarinitiativet anger som ett kriterium för eutanasi att "patienten lider av en obotlig sjukdom som leder till döden som kommer att inträffa inom en nära framtid också utan eutanasi». »Död inom den närmaste framtiden» är ett vagt uttryck. Inom medicinen är det allmänt erkänt att det är svårt att förutsäga livslängden och att det inte finns tillförlitliga indikatorer (Saarto, 2017; se också kap. 14). När det gäller mänskligt liv bör beslutsfattandet baseras på individuella livstidsbedömningar. Det finns knappast tillräckliga indikatorer till grund för lagstiftningen.

Läkaren är skyldig att informera patienten om hans eller hennes tillstånd och tillbudsstående vårdalternativ. Ofta kan endast specialistläkare i palliativ vård veta och berätta tydligt om vårdalternativen. Det finns inte kriterier angivna i medborgarinitiativet vilka läkare som skulle vara skyldiga att bedöma patienten. Det finns inte heller några krav på att den andra läkaren gör samma bedömning som den första, att inga möjligheter till väsentlig lindring finns. Således är det oklart hur man ska göra om läkarnas bedömningar skiljer sig från varandra. 


\section{Autonomi?}

Författarna och tillskyndarna till initiativet betonar att individuell autonomi är ett skäl för eutanasi (Seppänen, 2018; Lax, 2017; Elonheimo, 2018). Även om patienten enligt medborgarinitiativet vore proaktiv $i$ att be om eutanasi skulle läkaren vara skyldig att beakta alla eutanasikriterier som anges i initiativet. I slutändan är läkaren den som avsiktligt dödar patienten när eutanasi utförs. Läkaren skulle också ta fullt ansvar för att processen utförs i enlighet med lagen - i annat fall finns det risk för rättsliga påföljder (se kap. 9 och 15). Eftersom hela processen huvudsakligen bygger på läkarens aktivitet och handlingar, kan eutanasi inte betraktas som en självständig handling från patientens sida. Man kan jämföra det här till den allmänna principen i vård, att patienten inte kan bestämma vilken vård läkaren utför utan endast neka att ta emot vård (Louhiala, 2017; FKL, 2018).

I Finland ger lagen om patientens ställning och rättigheter patienten rätt att vägra ta emot behandling, också sådan som är livsuppehållande. Då får döden komma naturligt utan att dess ankomst blir utdragen. I medborgarinitiativet skiljer man detta inte tydligt från avsiktligt dödande handlingar vilka kännetecknar eutanasi. Denna förvirring upprepas i expertutlåtandet som initiativtagarna åberopar, där man använder samma term kuolinapu (dödshjälp) för eutanasi och för palliativ sedering (Lax, 2017).

Principen om tillgång till palliativ vård och behandling är att stödja patientens individualitet och att uppmana patienten att uttrycka sina önskningar. Detta stöds särskilt av strävan att uppmana patienter att författa vårdtestamenten som sedan registreras i patientjournalen. I vårdplanen beaktas vårdtestamentet, vilket säkerligen skingrar patientens rädsla och tvetydigheterna om hur patienten behandlas under de sista skedena i hans eller hennes liv. Vårdtestamentet och vårdplanen är ett av svaren på de farhågor och rädslor som medborgarinitiativet om eutanasi har väckt gällande patientens autonomi (FKL, 2018).

\section{Bedömning av patientens beslut}

Ansvaret för att bedöma lämpligheten av patientens beslut är läkarens. För att begäran ska vara övervägd, upprepad och permanent behövs tid. Således kan eutanasiprocessen knappast börja i omedelbar närhet av döden. 
Socialpsykologiska studier har visat att många av de beslut som vi betraktar som enskilda interagerar med samhället. Således kan exempelvis den offentliga beskrivningen av höga vårdkostnader för äldre och otillräcklig ekonomi påverka individens tänkande och åsiktsbildning (Hallamaa, 2017a). I USA har nästan hälften av dem som begått läkarassisterat självmord haft känslan av att vara en börda (Ezekiel, OnwuteakaPhilipsen, Urwin \& Cohen, 2016). Detta antyder att trycket från miljö och samhälle är betydande orsaker till dödsönskan. Det är emellertid svårt att visa för en enskild individ i vilken utsträckning miljöfaktorer har inverkat på patientens beslut om patienten själv inte känner dem (Saarto, 2017). Läkarens skyldighet att undersöka och klargöra detta skulle kräva information om patientens miljö utöver läkarens grundläggande kunskaper. Kanske en heltäckande bedömning skulle kräva nätverksbaserat samarbete mellan flera aktörer, något som skulle vara resurskrävande.

Många psykiska sjukdomar påverkar patientens beslutsfattande. Enligt medborgarinitiativets kriterium bör eutanasi inte tillämpas på personer som är deprimerade eller vars omdöme är nedsatt av psykisk sjukdom. När det gäller en patient som lider av en psykisk sjukdom, skulle en lämplig bedömning troligen kräva en psykiater eller en psykolog för att undersöka och kommentera (se kap. 11). Dessa processer tar lång tid att genomföra korrekt och kräver också resurser.

\section{Negligering av medicinsk etik}

Medborgarinitiativet om eutanasi är beroende av läkarexpertis för bedömning av villkoren för och utförande av eutanasi. Initiativet negligerar dock den etiska kompetensen hos läkarprofessionen i fråga om eutanasi. Finlands Läkarförbund har i sin expertutlåtande påpekat att eutanasi strider mot medicinsk etik (Finlands Läkarförbund, 2018): Eutanasi är inte en terapeutisk handling och ingår därför inte i vården. Att överföra eutanasi på läkare skulle bara ske därför att läkarkåren har det kunnande som eutanasi kräver. Eutanasi strider mot läkarprofessionens grundläggande principer, respekt och skydd för liv. Läkarens etiska plikt är att lindra lidande i livets slutskede men detta leder inte till någon 
skyldighet eller rättfärdigande för läkaren att aktivt ända patientens liv för att avsluta lidande (Finlands Läkarförbund, 2018).

Eutanasianhängare reagerar på läkarnas motstånd åtminstone på tre sätt. I medborgarinitiativet ignoreras läkarprofessionens åsikter. Antagandet syns vara att det $\mathrm{i}$ alla fall finns tillräckligt med läkare som är redo att utföra eutanasi. Å andra sidan har man ansett att läkarnas attityder ändras genom utbildning om eutanasi och om eutanasi skulle ses som en form av behandling. Slutligen återspeglas i initiativet idén om att läkarprofessionen inte skulle säga någonting, eftersom det är samhället som bestämmer om saken och varje person har rätt att bestämma över sitt eget liv (Hallamaa, 2017a).

Debatten har ignorerat det faktum att läkarprofessionen bevarar de sociala och universella värderingar som garanterar hög kvalitet i läkararbetet och skyddar verksamhetens integritet. Yrkets övriga expertdimensioner kan inte heller särskiljas från denna etiska kärna. Den etiska integriteten hos läkarprofessionen realiseras såväl i hur hela professionen verkar som hos den enskilda läkarens gärningar. På professionsnivå kommer integriteten till uttryck i att professionen försvarar sina centrala värden mot intressen som olika intressegrupper, också samhället, försöker pådyvla. En etiskt hög professionell nivå är en social resurs och en kritisk röst till stöd för ett välfungerande civilsamhälle (Saarni et al., 2013; Hallamaa, 2017a).

På individnivå manifesteras läkarens moraliska integritet i den kliniska autonomin, något som också skyddar patientens rättigheter. Klinisk autonomi betyder givetvis inte vilken som helst frihet för enskilda läkare att agera, utan den kliniska autonomin härleds ur hela professionens kompetens. Om riksdagen stiftade en lag om eutanasi på det sätt som anges i medborgarinitiativet, skulle riksdagen beröva autonomin från en av de viktigaste professionerna i samhället på ett sätt som vore etiskt ohållbart (Hallamaa, 2017a).

\section{Juridiska problem, patientens och läkarens rättsskydd, patientsäkerhet}

Det har påpekats i expertutlåtanden att eutanasi i princip inte är tillåten i länder där eutanasi genomförs. Lagstiftningen har bara skapat kriterier 
som gör att eutanasi inte är straffbart. En lag om eutanasi är därför i princip juridiskt kontroversiell. Således är eutanasi bland annat i Beneluxländerna ett brott som dock inte bestraffas under vissa omständigheter (Hallamaa, 2017b).

Medborgarinitiativet föreslår en modell för att genomföra eutanasi, där lagenligheten av genomförandet av eutanasi kommer att utvärderas $i$ efterhand av det övervakningsorgan som inrättats för detta ändamål. Detta vore en synnerligen problematisk praxis för det rättsliga skyddet för både patienten och läkaren. Det har framgått att kriterierna för eutanasi inkluderar begrepp som inte är tydliga, och det finns dessutom inga allmänt accepterade principer för utvärdering av de presenterade kriterierna. Medborgaren kan således bli föremål för en gärning som orsakar döden utan någon tidigare rättslig bekräftelse av gärningens legitimitet. Detta strider mot individens och patientens rättsliga skydd, särskilt då gärningen är irreversibel och inte kan krediteras eller repareras. På liknande sätt ställer eutanasiskyldigheten läkaren i en juridiskt problematisk situation då läkaren skulle begå en handling som per definition vore olaglig, men vars straff skulle fastställas först efter gärningen (Saarni et al., 2013; Hallamaa, 2017b). Jurister som är för eutanasi förbigår gärna det här problemet och glömmer patientsäkerhetens svårigheter (Nieminen, 2018).

I Nederländerna rapporteras inte $23 \%$ av utförda eutanasier (Onwuteaka-Philipsen et al., 2012), i Belgien upp till 50 \% (Smets et al., 2010). I dessa länder undersöker organen som bedömer eutanasifallen endast dem som rapporteras till dem. Expertrapporterna betonade oron att om Finland hade likadana tillsynsorgan som dessa länder, skulle ett liknande problem med eutanasier som inte rapporterades uppstå hos oss. Patientsäkerheten skulle otvetydigt äventyras (Saarto, 2017; FKL, 2018).

Initiativet introducerar samvetsfrihet för läkare och vårdpersonal att delta eller vägra delta i eutanasi. När det gäller en läkare skulle samvetsfriheten emellertid inte vara komplett, eftersom läkaren skulle vara skyldig att delta i utförandet av eutanasi på grund av sin skyldighet att remittera patienten till en annan läkare, redo att utföra eutanasi då kriterierna är uppfyllda. Enligt expertutlåtandena förverkligas samvetsfriheten för läkare först då läkaren inte behöver delta i processen på något sätt (FKL, 2018). 


\section{Sluttande plan}

Flera studier har genomförts i olika länder om genomförandet av eutanasi och läkarassisterat självmord under den tid som det praktiserats. Flera expertutlåtanden har avgetts till riksdagens social- och hälsovårdsutskott där man påpekat att både statistik och studier visar att genomförandet av eutanasi har ökat stadigt och att genomförandet också har utvidgats till nya populationer. Kriterierna för genomförande av eutanasi har således utvidgats (Boer, 2018; Saarto, 2017; FKL, 2018; Pöyhiä, 2018; Hallamaa, 2017b; se också kap. 13). Om den föreslagna eutanasilagen stiftades, skulle oron för fenomenet med det sluttande planet i Finland vara stor enligt både riksdagsledamöternas första öppna diskussion och expertutlåtandena (Riksdagen, 2017b; FKL, 2018; Saarto, 2017; Finlands Läkarförbund, 2018; Pöyhiä, 2018).

Författarna till medborgarinitiativet säger enligt deras expertutlåtande att avsikten med information om sluttande plan är att åstadkomma en skrämseleffekt. De hänvisar till att lagen skulle komma att fastställa straff för överträdelser och därigenom leda till korrekt funktion, precis som fallet är med vilken lag som helst (Lax, 2017; Seppänen, 2018). De reflekterar dock inte över möjligheten att kriterierna eller lagens tilllämpning skulle utsättas för tryck för förändring som skulle leda till ett sluttande plan. Den praktiska erfarenheten som gäller utvidgningen av användningen av eutanasi i Nederländerna och Belgien ignoreras, men talar sitt tydliga språk (se kap. 13). Det finns i förslaget ingen uttalad oro för patientsäkerheten, som äventyras.

Expertrapporterna lyfte fram det faktum att det för närvarande, på grund av bristande organisation och tillgång till palliativ vård och vård i livets slutskede, skulle vara problematiskt att stifta en eutanasilag. Om eutanasi tilläts, skulle eutanasi de facto användas istället för god vård i livets slutskede (Finlands Läkarförbund 2018, Saarto 2017, Nevala 2018).

\section{Livets värde}

Om man stiftade en eutanasilag i Finland, skulle det oundvikligen kräva att man bestämmer när livet inte längre är värt att leva. Enligt det föreslagna sättet att verkställa eutanasi skulle begreppet värdelöst liv 
definieras utgående från hälsokriterier, från lidande. Detta ses i handikapporganisationens expertutlåtande som ett hot mot värdigheten hos personer med funktionsnedsättning (Könkkölä, 2018). Handikapporganisationerna verkar inte vara nöjda med det individualistiska argumentet att eutanasi inte tar ställning till livets värde, utan att åtgärden skulle baseras på individens viljeyttring. Detta argument tar inte hänsyn till utvärderingsprocessen bakom varje eutanasibeslut (Hallamaa, 2017b; se också kap. 9). I expertutlåtanden anser man att livets värde inte kan bestämmas utgående från lidande (Sipola, 2018; FKL, 2018).

\section{Betoning av argument i riksdagsbehandlingen}

Debatten om eutanasiinitiativet i riksdagen visade vilka argument riksdagsledamöterna använder när de bedömer medborgarinitiativet. Det var också möjligt att se påverkan av det lobbyarbete som hade gjorts för och mot initiativet. Initiativets författare upprepade argumenten om individens autonomi och diskuterade nödvändigheten av möjligheten till eutanasi vid oacceptabelt lidande, eftersom de ansåg att bra palliativ vård inte gav tillräcklig lättnad till de mest lidande.

Motståndarna till eutanasi betonade behovet av att allra först få högkvalitativ palliativ vård och vård i livets slutskede för alla och först då kan vi bedöma om det finns något verkligt behov av eutanasi. Diskussionen visade att åsikterna påverkades av ett utlåtande till riksdagen av ETENE (2017) och en skrivelse av några läkare vid de palliativa avdelningarna i universitetssjukhusen (Saarto et al., 2017b). Dessa bidrog till att någon lag om eutanasi inte stiftades, utan istället stiftades en lag om vård i livets slutskede som skulle leda till att både utbildning och praktisk omsorg skulle utvecklas till en målnivå. Om en lag om eutanasi stiftades nu, skulle den de facto ersätta bristerna i vården i livets slutskede i dagens Finland. Liknande argumentation upprepades i flera utlåtanden som tillställdes riksdagens social- och hälsovårdsutskott.

Det var signifikant att en tydlig förändring i riksdagsledamöternas åsikter sågs under förfarandet. I början av riksdagsperioden stödde en majoritet av riksdagsledamöterna dödshjälp, men vid den slutliga omröstningen om eutanasiinitiativet var en klar majoritet negativa. 
Riksdagens social- och hälsovårdsutskott samlade viktiga åsikter i sitt betänkande, men hänsyn till patientsäkerhetsfrågan togs inte. Betänkandet går inte djupare in i argumentation. Det erkänner brister i vården $\mathrm{i}$ livets slutskede och erkänner också att eutanasifrågan och vården i livets slutskede kräver ytterligare en heltäckande utredning innan ytterligare åtgärder vidtas (Social- och hälsovårdsutskottet, 2018).

\section{Nuvarande situation och åtgärder}

Enligt riksdagens beslut gällande medborgarinitiativet om eutanasi har social- och hälsovårdsministeriet (SHM) tillsatt »en brett sammansatt expertgrupp för att utreda behovet av lagstiftning om god vård i livets slutskede, självbestämmanderätten samt vård i livets slutskede och eutanasi» och dess mandatperiod sträcker sig till juni 2021 (SHM, 2018). SHM tillsatte också en annan expertgrupp som utreder vården i livets slutskede och behovet av utbildning.

Den första expertgruppen ska undersöka alla de förslag som riksdagsledamöterna har lagt fram för att förbättra lagstiftningen om vården $\mathrm{i}$ livets slutskede. Den bereder också frågan om det finns behov av en eutanasilag. Diskussioner i denna grupp betyder mest för den fortsatta beredningen av frågan.

Den andra expertgruppen har publicerat ett betänkande om sina forskningsresultat enligt vilket brister $\mathrm{i}$ vården $\mathrm{i}$ livets slutskede och $\mathrm{i}$ utbildningen har identifierats (Saarto et al., 2019). Institutet för hälsa och välfärd har börjat beskriva servicekedjor till stöd för det kliniska arbetet kring vården i livets slutskede (Institutet för hälsa och välfärd, 2018a och 2018b).

Diskussionen om eutanasi och läkarassisterat självmord fortsätter.

Hjärtligt tack till docent Robert Paul och överläkare Mikaela Luthman för språkgranskning av manuskriptet.

\section{Referenser}

Appelsin, U. (2016, 18 december). 3-vuotiaan Einon lääkäri-isän puheenvuoro: »Olisin halunnut pojalleni eutanasian». Ilta-Sanomat. Hämtad från http://www. iltasanomat.fi/kotimaa/art-2000005010252.html 
Boer, T. (2018). KAA 2/2017 vp StV 02.03.2018 professori Theo Boer, Teologinen yliopisto Kampen Asiantuntijalausunto. Hämtad från https://www.eduskunta.fi/ FI/vaski/JulkaisuMetatieto/Documents/EDK-2018-AK-175949.pdf

Carrasco, J. M, Lynch, T. J., Garralda, E., Woitha, K., Elsner, F., Filbet, M., ... Centeno, C. (2015). Palliative care medical education in European universities: A descriptive study and numerical scoring system proposal for assessing educational development. J Pain Symptom Manage 63, 255-68. https://doi. org/10.1016/j.jpainsymman.2015.04.019

Council of Europe. (2003). Recommendation Rec (2003) 24 of the Committee of Ministers to member states on the organisation of palliative care. Hämtad från https://www.coe.int/t/dg3/health/Source/Rec(2003)24_en.pdf

Council of Europe. (2012). Resolution 1859 (2012). Protecting human rights and dignity by taking into account previously expressed wishes of patients. Hämtad från http://assembly.coe.int/nw/xml/XRef/Xref-XML2HTML-en. asp? fileid $=18064$ \&lang=en

Council of Europe. (2014). Written declaration 567 (2014) Doc. 13414. Legalisation of euthanasia for children in Belgium. Hämtad från http://assembly.coe.int/nw/xml/ XRef/Xref-DocDetails-EN.asp?fileid=20905\&lang=EN\&search=MTMoMTR8Y 29ycHVzX25hbWVfZW46Ik9mZmljaWFsIGRvY3VtZW5ocyI=

Elonheimo, P. (2018). KAA 2/2017 vp StV 15.02.2018 varapuheenjohtaja Pekka Elonheimo, Exitus ry Asiantuntijalausunto. Hämtad från https://www.eduskunta. fi/FI/vaski/JulkaisuMetatieto/Documents/EDK-2018-AK-168375.pdf

European Court of Human Rights. (2019). End of life and the European Convention on Human Rights. Hämtad från https://www.echr.coe.int/Documents/FS_ Euthanasia_ENG.pdf

Ezekiel, E. J., Onwuteaka-Philipsen, B. D., Urwin, J. W. \& Cohen, J. (2016). Attitudes and practices of euthanasia and physician-assisted suicide in the United States, Canada, and Europe. JAMA, 316(1), 79-90. https://doi.org/ 10.1001/jama.2016.8499

Finlands Kristna Läkarförbund (FKL). (2018). KAA 2/2017 vp StV 06.03.2018 Suomen Kristillinen Lääkäriseura Asiantuntijalausunto. Hämtad från https:// www.eduskunta.fi/FI/vaski/JulkaisuMetatieto/Documents/EDK-2018-AK-174871. pdf

Finlands Läkarförbund. (2017a). Lääkäriliiton kysely: Saattohoito kehittynyt viimeisten vuosien aikana. 13.2.2017. Kuolevia potilaita hoitavien lääkärien mielipiteitä saattohoidosta ja eutanasiasta. Hämtad från https://www.laakariliitto. fi/uutiset/ajankohtaista/laakariliiton-kysely-saattohoito-kehittynyt-viimeistenvuosien-aikana/

Finlands Läkarförbund. (2017b). Tietoa eutanasiasta. Hämtad från https://www. laakariliitto.fi/laakariliitto/etiikka/tietoa-eutanasiasta/ 
Finlands Läkarförbund. (2018). KAA 2/2017 vp StV 15.02.2018 Suomen Lääkäriliitto ry Asiantuntijalausunto. Hämtad från https://www.eduskunta.fi/FI/vaski/ JulkaisuMetatieto/Documents/EDK-2018-AK-170295.pdf

Finska Läkarföreningen Duodecim. (2018). Palliatiivinen hoito ja saattohoito. 16.2.2018. Hämtad från http://www.kaypahoito.fi/web/kh/suositukset/ suositus?id=hoi50063

Finska Läkarföreningen Duodecim. (2019). God medicinsk praxis. Hämtad från https://www.kaypahoito.fi/sv/

Hakala, K. (2018). Riksdagsbibliotek. Informationspaket om lagprojekt - LATI. Eutanasia-kansalaisaloite. Hämtad från https://www.eduskunta.fi/FI/ tietoaeduskunnasta/kirjasto/aineistot/kotimainen_oikeus/LATI/Sivut/eutanasiakansalaisaloite.aspx

Hallamaa, J. (2017a, 2. mars). Eutanasiasta kerrotaan vain kauniita tarinoita Vastustajat leimataan julmureiksi. Suomen Kuvalehti. Hämtad från https:// suomenkuvalehti.fi/jutut/kotimaa/eutanasiasta-kerrotaan-kauniita-tarinoitavastustajat-leimataan-julmureiksi/?shared $=960142-$ e219aab6-999

Hallamaa, J. (2017b). KAA 2/2017 vp StV 09.11.2017 professori Jaana Hallamaa, Helsingin yliopisto Asiantuntijalausunto. Hämtad från https://www.eduskunta.fi/ FI/vaski/JulkaisuMetatieto/Documents/EDK-2018-AK-177633.pdf

Hänninen, J. (2012). Eutanasia, hyvä kuolema. Helsinki: Duodecim.

Hänninen, J. (2018). KAA 2/2017 vp StV 01.03.2018 lääkäri Juha Hänninen, Terhokoti Asiantuntijalausunto. Hämtad från https://www.eduskunta.fi/FI/vaski/ JulkaisuMetatieto/Documents/EDK-2018-AK-171399.pdf

Institutet för hälsa och välfärd (THL). (2018a). Elämän loppuvaiheen hoidon tutkimusja kehittämishanke PACE. Hämtad från https://thl.fi/fi/tutkimus-ja-kehittaminen/ tutkimukset-ja-hankkeet/elaman-loppuvaiheen-tutkimus-ja-kehittamishanke

Institutet för hälsa och välfärd (THL). (2018b). Servicekedjor - service till livets slut. 31.10.2018. Hämtad från https://thl.fi/sv/web/aldre/fungerande-aldreomsorg/ servicekedjor-service-till-livets-slut

Kotila, H. (Red.) (1995). Elämän pyhyys ja ihmisen halu kuolla. Puheenvuoroja eutanasiasta. Helsinki: Kirjaneliö.

Könkkölä, K. (2018). KAA 2/2017 vp StV 06.03.2018 toiminnanjohtaja Kalle Könkkölä, Kynnys ry Asiantuntijalausunto. Hämtad från https://www.eduskunta. fi/FI/vaski/JulkaisuMetatieto/Documents/EDK-2018-AK-174981.pdf

Lahti, R. (2017). KAA 2/2017 vp StV 09.11.2017 professori (emeritus) Raimo Lahti, Helsingin yliopisto Asiantuntijalausunto. Hämtad från https://www.eduskunta.fi/ FI/vaski/JulkaisuMetatieto/Documents/EDK-2018-AK-177639.pdf

Lax, H. (2017). KAA 2/2017 vp StV 09.11.2017 aloitteen tekijöiden edustaja Henrik Lax Asiantuntijalausunto. Hämtad från https://www.eduskunta.fi/FI/vaski/ JulkaisuMetatieto/Documents/EDK-2018-AK-177629.pdf 
Lehtonen, L. (2018). KAA 2/2017 vp StV 08.02.2018 professori Lasse Lehtonen, Helsingin yliopisto Asiantuntijalausunto. Hämtad från https://www.eduskunta.fi/ FI/vaski/JulkaisuMetatieto/Documents/EDK-2018-AK-177679.pdf

Louhiala, P. (2017). KAA 2/2017 vp StV 09.11.2017 dosentti Pekka Louhiala Asiantuntijalausunto. Hämtad från https://www.eduskunta.fi/FI/vaski/ JulkaisuMetatieto/Documents/EDK-2018-AK-177640.pdf

Louhiala, P., Enkovaara, H., Halila, H., Pälve, H. \& Vänskä, J. (2015). Finnish physicians' attitudes towards active euthanasia have become more positive over the last 10 years. J Med Ethics, 41, 353-355. http://dx.doi.org/10.1136/ medethics-2014-102459

Medborgarinitiativ.fi. (2016). Motion om eutanasi för en god död. Justitieministeriets ärendenummer OM 111/52/2016. Hämtad från https://www.kansalaisaloite.fi/sv/ initiativ/2212

Mäki, K. (2017, 22. februari). Elämän lopun hoidon ja toimenpiteiden terminologiaa. Finlands Läkarförbund. Hämtad från https://www.laakariliitto.fi/site/assets/ files/5121/elaman_lopun_hoidon_ja_toimenpiteiden_terminologiaa.pdf

Natri, S. (2016, 27. december). Ylen kysely: Eutanasian sallisi suurin osa suomalaisista. Hämtad från https://yle.fi/uutiset/3-9360962

Nevala, S. (2018). KAA 2/2017 vp StV 15.02.2018 asiantuntija Soili Nevala, Suomen lähi- ja perushoitajaliitto SuPer ry Asiantuntijalausunto. Hämtad från https:// www.eduskunta.fi/FI/vaski/JulkaisuMetatieto/Documents/EDK-2018-AK-169856. pdf

Nieminen, L. (2018). Kuka saa päättää sinun elämäsi lopusta? Eduskuntakeskustelun analyysi. Oikeus, 47(3), 391-415.

Nuotio, K. (2018). KAA 2/2017 vp StV 15.02.2018 professori Kimmo Nuotio, Helsingin yliopisto Asiantuntijalausunto. Hämtad från https://www.eduskunta.fi/ FI/vaski/JulkaisuMetatieto/Documents/EDK-2018-AK-177693.pdf

Onwuteaka-Philipsen, B. D., Brinkman-Stoppelenburg, A., Penning, C., de JongKrul, G. J. F., van Delden, J. J. M. \& van der Heide, A. (2012). Trends in end-of-life practices before and after the enactment of the euthanasia law in the Netherlands from 1990 to 2010: A repeated cross-sectional survey. Lancet, 380(9845), 908-15.

Pihlainen, A. (2010) Hyvä saattohoito Suomessa. Asiantuntijakuulemiseen perustuvat saattohoitosuositukset. Sosiaali- ja terveysministeriö. Sosiaali- ja terveysministeriön julkaisuja. Social- och hälsovårdsministeriets publikationer 2010:6. Hämtad från http://urn.fi/URN:ISBN:978-952-00-3033-9

Pirkanmaan hoitokoti. (2017). Saattohoitolakia tarvitaan. Hämtad från https://www. pirkanmaanhoitokoti.fi/@Bin/209381/saattohoitolaki.pdf

Pöyhiä, R. (2018). KAA 2/2017 vp StV 08.02.2018 johtava ylilääkäri Reino Pöyhiä, Kaunialan Sairaala Oy Asiantuntijalausunto. Hämtad från https://www. eduskunta.fi/FI/vaski/JulkaisuMetatieto/Documents/EDK-2018-AK-177676.pdf 
Pöyhiä, R., Reinikainen, P. \& Tasmuth, T. (Red.) (2014) Lääkäri saattajana.

Pohdintoja kärsimyksestä, kuolemasta ja eutanasiasta. Helsinki: Duodecim.

Räsänen, P. (2017). Mistä on kysymys? Eutanasia. Ryttylä: Kustannus Oy Uusi Tie.

Riksdagen. (2017a). Motion om eutanasi for en god död 7.11.2016. Riksdagen MI 2/2017 rd. Hämtad från https://www.eduskunta.fi/SV/vaski/JulkaisuMetatieto/ Documents/MI_2+2017.pdf

Riksdagen. (2017b). Punkt i protokollet PR 16/2017 rd. Hämtad från https://www. eduskunta.fi/SV/vaski/PoytakirjaAsiakohta/Sidor/PR_16+2017+3.aspx

Riksdagen. (2018). KAA 2/2017 vp, Eutanasia-aloite hyvän kuoleman puolesta. Lain säätäminen, valiokuntien asiantuntijalausunnot. Hämtad från https:// www.eduskunta.fi/FI/vaski/KasittelytiedotValtiopaivaasia/Sivut/KAA_2+2017_ asiantuntijalausunnot.aspx

Riksomfattande etiska delegationen inom social- och hälsovården ETENE. (2001). Kuolemaan liittyvät eettiset kysymykset terveydenhuollossa. ETENE julkaisuja 4. Helsinki. Hämtad från https://etene.fi/documents/1429646/ 1559098/ETENE-julkaisuja+4+Kuolemaan+liittyv\%C3\%A4t+eettiset+kysymyk set+terveydenhuollossa.pdf/6a1cdo43-354c-486d-b554-egf37159924e/ETENEjulkaisuja +4+Kuolemaan+liittyv\% $3 \%$ A4t+eettiset+kysymykset+terveydenhu ollossa.pdf.pdf

Riksomfattande etiska delegationen inom social- och hälsovården ETENE. (2003).

Vård i livets slutskede. Promemoria utgiven av riksomfattande etiska delegationen inom hälso- och sjukvården (ETENE). Vantaa. Hämtad från http://etene.fi/documents/1429646/155909o/Ty\%C3\%B6ryhm\%C3\%A4n+ raportti+saattohoidosta.pdf/4ca4d3d8-90a7-429e-8ba4-4e1bcfa2d75a

Riksomfattande etiska delegationen inom social- och hälsovården ETENE. (2011). Kannanotto eutanasiasta, 21.12.2011 reducerad 3.1.2012. Hämtad från https://etene.fi/documents/1429646/1556028/Kannanotto+eutanasiasta.pdf/ e73do2db-015e-4945-8258-oe1d9ae6510a/Kannanotto+eutanasiasta. pdf.pdf

Riksomfattande etiska delegationen inom social- och hälsovården ETENE. (2012). Saattohoito Suomessa vuosina 2001, 2009 ja 2012. Suunnitelmat ja toteutus. ETENE-julkaisuja 36. Hämtad från https://etene.fi/documents/1429646/1559054/ ETENE-julkaisuja+36+Saattohoito+Suomessa+vuosina+2001\%2C+2009+ ja+2012+-+suunnitelmat+ja+toteutus.pdf/58ee136a-919b-4e32-8b18-f131143747a7/ ETENE-julkaisuja+36+Saattohoito+Suomessa+vuosina+2001\%2C+2009+ ja+2012+-+suunnitelmat+ja+toteutus.pdf

Riksomfattande etiska delegationen inom social- och hälsovården ETENE. (2017). ETENEn kannanotto eutanasiaan. 26.9.2017. STM105:00/2014. Hämtad från http://etene.fi/documents/1429646/4360417/KANNANOTTO_eutanasia_ 26.9.2017f.pdf/a23dcc78-3788-4140-b363-3a7b99527ad8 
Saarni, S., Kattelus, M. \& Nummi, V. (Red.). (2013). Läkaretik. 7. upplagan (152-164). Helsingfors: Finlands Läkarförbund. Hämtad från https://www.laakariliitto.fi/ tutkimus/kirjat/

Saarto, T. (2017). KAA 2/2017 vp StV 09.11.2017 professori Tiina Saarto, Helsingin yliopisto Asiantuntijalausunto. Hämtad från https://www.eduskunta.fi/FI/vaski/ JulkaisuMetatieto/Documents/EDK-2018-AK-177637.pdf

Saarto, T. ja asiantuntijatyöryhmä. (2017a). Palliatiivisen hoidon ja saattohoidon järjestäminen. Työryhmän suositus osaamis- ja laatukriteereistä sosiaalija terveydenhuollon palvelujärjestelmälle. Sosiaali- ja terveysministeriön raportteja ja muistioita 2017:44. Hämtad från http://julkaisut.valtioneuvosto.fi/ handle/10024/160392

Saarto, T., Lehto, J., Rahko, E., Hirvonen, O. \& Tyynelä-Korhonen, K. (2017b). Ei eutanasiaa vaan saattohoitolaki.

Saarto, T., Finne-Soveri, H. ja asiantuntijatyöryhmä. (2019). Palliatiivisen hoidon ja saattohoidon tila Suomessa. Alueellinen kartoitus ja ehdotuksia laadun ja saatavuuden parantamiseksi. Sosiaali- ja terveysminiesteriön raportteja ja muistioita 2019:14. Helsinki. Hämtad från http://julkaisut.valtioneuvosto.fi/ bitstream/handle/10024/161396/R_14_19_Palliatiivisen_hoidonjasaattohoidon_ tila.pdf? sequence $=1$ \&isAllowed $=\mathrm{y}$

Sauli, M. (2016). Suurin osa kansanedustajista sallisi eutanasian. YLE A-studio 14.11.2016. Hämtad från https://yle.fi/uutiset/3-9292231

Seppänen, E. (2018). KAA 2/2017 vp StV 01.03.2018 aloitteen tekijöiden edustaja Esko Seppänen Asiantuntijalausunto. Hämtad från https://www.eduskunta.fi/FI/ vaski/JulkaisuMetatieto/Documents/EDK-2018-AK-173089.pdf

Seppänen, E. \& Taipale, I. (2013). Eutanasia. Helsinki: Into Kustannus Oy. Sipola, V. (2018). KAA 2/2017 vp StV 08.02.2018 asiantuntija Virpi Sipola, Kirkkohallitus Asiantuntijalausunto. Hämtad från https://www.eduskunta.fi/FI/ vaski/JulkaisuMetatieto/Documents/EDK-2018-AK-177681.pdf

Smets, T., Bilsen, J., Cohen, J., Rurup, M. L., Mortier, F. \& Deliens, L. (2010). Reporting of euthanasia in medical practice in Flanders, Belgium: cross sectional analysis of reported and unreported cases. BMJ, 341, C5174. https://doi.org/10.1136/ bmj.c5174

Smets, T., van Dop, N., Pivodic, L., Piers, R., Pasman, H. R. W., Vernooij-Dassen, M., ... Van den Block, L. (2018). The palliative care knowledge of nursing home staff: The EU FP7 PACE cross-sectional survey in 322 nursing homes in six European countries. Palliative Medicine 32(9), 1487-1497.

Social- och hälsovårdsministeriet (SHM). (2018) Elämän loppuvaiheen hoito -työryhmä. STMo55:00/2018. Hämtad från https://stm.fi/hanke/-/hankesivu/ hanke?tunnus=STMo55\%3Aoo\%2F2018 https://stm.fi/sv/artikeln/-/asset_ publisher/asiantuntijaryhma-selvittaa-elaman-loppuvaiheen-hoitoa-ja-eutanasiaa 
Social- och hälsovårdsutskottet. (2018). Betänkande ShUB 42018 rd - MI 2/2017 rd. Hämtad från https://www.eduskunta.fi/SV/vaski/Mietinto/Sidor/ShUB_4+2018. aspx

Tyynelä-Korhonen, K. (2018). KAA 2/2017 vp StV 08.02.2018 onkologi, LT Kristiina Tyynelä-Korhonen, Suomen palliatiivisen lääketieteen yhdistys ry Asiantuntijalausunto. Hämtad från https://www.eduskunta.fi/FI/vaski/ JulkaisuMetatieto/Documents/EDK-2018-AK-177670.pdf

WMA. (2002 rev. 2013). WMA Resolution on Euthanasia (2002, reaffirmed by minor revision 2013). Hämtad från https://www.wma.net/policies-post/wma-resolutionon-euthanasia/

WMA. (2015). WMA Declaration on Euthanasia (1987, reaffirmed 2015). Hämtad från https://www.wma.net/policies-post/wma-declaration-on-euthanasia/

WMA. (2019). WMA Declaration on Euthanasia and Physician-Assisted Suicide 2019. Hämtad från https://www.wma.net/policies-post/declaration-oneuthanasia-and-physician-assisted-suicide/

\section{Ordforklaringer}

avyttras: afhændes/avhendes (D/N)

befintlig: eksisterende $(\mathrm{D}, \mathrm{N})$

befogade: berettigede $(\mathrm{D}, \mathrm{N})$

enligt: ifølge (D, N)

f.d. (före detta): forhenværende $(\mathrm{D}, \mathrm{N})$

farhågor: bekymringer $(\mathrm{D}, \mathrm{N})$

gynnsamt: gunstigt (D), positivt (N)

handlingsförmåga: habilitet $(\mathrm{D})$, beslutningskompetanse $(\mathrm{N})$

heltäckande: udtømmende/uttømmende (D/N)

hot: trussel (D, N)

härledas: udledes/utledes $(\mathrm{D} / \mathrm{N})$

i efterhand: i retrospekt $(\mathrm{D}, \mathrm{N})$

inväntas: afventes/avventes $(\mathrm{D} / \mathrm{N})$

ledamöterna: medlemmerne/medlemmene (D/N)

lämpligt: adækvat/adekvat (D/N)

märkvärdigt: bemærkelsesværdigt/bemerkelsesverdig $(\mathrm{D} / \mathrm{N})$

omdöme: dømmekraft (D, N)

outhärdliga: uudholdelige/uutholdelige $(\mathrm{D} / \mathrm{N})$

pådyvla: påtvinge $(\mathrm{D}, \mathrm{N})$

sakkunnigutlåtanden: ekspertrapport $(\mathrm{D}, \mathrm{N})$

samförstånd: samråd (D, N) 
servicekedjor: patientforløb/pasientforløp (D/N)

skingra: fordrive $(\mathrm{D}, \mathrm{N})$

skyldighet: forpligtelse/forpliktelse $(\mathrm{D} / \mathrm{N})$

skäl: grunder/grunner $(\mathrm{D} / \mathrm{N})$

sluttande: skrånende $(\mathrm{D}, \mathrm{N})$

stadgar: fastslår $(D, N)$

stödförklaringar: støtteerklæringer (D, N)

tillsatte: utpegte/utpekte (D/N)

upprepad: gentaget/gjentatt $(\mathrm{D} / \mathrm{N})$

uppsatser: essays $(\mathrm{D}, \mathrm{N})$

utskott: udvalg/utvalg $(\mathrm{D} / \mathrm{N})$

utvärderas: evalueres $(\mathrm{D}, \mathrm{N})$

vård: behandling og pleje/pleie $(\mathrm{D} / \mathrm{N})$

övergripande: overordnede $(D, N)$

åsikter: synspunkter (D, N)

åläggs: pålægges/pålegges $(\mathrm{D} / \mathrm{N})$

äventyras: settes i spill $(\mathrm{D}, \mathrm{N})$ 
Del II

Etikk 



\title{
KAPITTEL 5
}

\section{Legalisering af dødshjælp - den indirekte afvisning}

\section{Ole Hartling}

Vejle Sygehus

\begin{abstract}
Legalisation of assisted dying is supported in particular by two arguments: 1) avoiding unbearable suffering and 2) respecting the right of self-determination (individual autonomy). This chapter raises objections to both. It is problematic that assisted dying aims to remove the suffering by eliminating the sufferer. The argument for respect for the right of self-determination is also analysed, with emphasis on autonomy in the sense that the Danish Health Care Act affords an unlimited right to refuse treatment, but not a right to demand a specific treatment. Whether autonomy is genuinely possible in connection with assisted dying is questioned, as autonomy will always be relative to an assessment of the patient's quality of life. How assisted dying can affect the patient-physician relationship is also discussed. Finally, there is the conclusion that if the distressed and despairing person is met with the suggestion that now death is to be preferred, this also sends a message that the person is dispensable.
\end{abstract}

Keywords: assisted dying, autonomy, euthanasia, physician-patient relationship, quality of life

Nogle vil mene, at vi har magt over døden i den forstand, at vi kan udskyde den. Vi kan for eksempel sørge for at leve så sundt som muligt. Vi kan lade være med at ryge og drikke, og vi kan huske at gå til læge, hvis vi får symptomer. Vi kan tilmed modtage såkaldt livsforlængende behandling, når døden er tættere på. Men grundlæggende er døden uden for vor magt, og vi har en sikker viden om, at den vil indtræde en dag, hvad vi end stiller op. 
Dødshjælp derimod ligger tilsyneladende mere inden for menneskers magtsfære, for når vi er magtesløse over for døden, kan vi i det mindste bestemme, hvornår den skal indtræffe. Det giver et indtryk af magt midt i magtesløsheden, for så har vi stadig en fornemmelse af, at det er os, som bestemmer. Det flugter med tidens ideer om menneskets kontrol over tilværelsen. Og det flugter med tanker om en fri vilje og en udstrakt selvbestemmelsesret. Allerede her må det dog erkendes, at vores selvbestemmelse er halveret: Vi kan vælge at $\mathrm{d} ø$, når vi lever, men vi kan ikke vælge at leve, når vi dør.

I de senere år er debatten om dødshjælp (eutanasi og assisteret selvmord) intensiveret i de vestlige lande. Debatten er dog ikke så ny, som mange antager. Allerede Hippokrates formodes at have kendt til problemstillingen, når han i sin ed (»Asklepiade-eden«) blandt andet siger: »Selv om jeg opfordres dertil, vil jeg ikke udlevere nogen dødelige gifte eller give noget sådant råd « (Citeret fra Godfredsen, 1964, s. 57). Spørgsmålet om dødshjælp er også jævnligt blevet debatteret i forrige århundrede. For eksempel skrev forfatteren G. K. Chesterton tilbage i 1937 i forbindelse med sin tids debat om dødshjælp: »[...] some are proposing what is called Euthanasia; at present only a proposal for killing those who are a nuisance to themselves; but soon to be applied progressively to those who are a nuisance to other people« (Chesterton, 1937, s. 490).

\section{To hovedargumenter for dødshjælp}

Argumenterne for en legalisering af dødshjælp er ret konstante. Der er især to, som fremføres i forskellige sprogdragter: 1) mulighed for at afhjælpe »ubærlig lidelse« og 2) respekt for selvbestemmelsesret. De kan kaldes debattens hovedargumenter, fordi andre formuleringer som bevarelse af værdighed for eksempel kan ses i sammenhæng med autonomi. Argumenterne er i udgangspunktet lette at følge, men jeg vil i det følgende se nærmere på dem og især fokusere på selvbestemmelsesretten. Ingen af de to argumenter kan stå alene, men vekselvirker, som jeg vil vise det, med hinanden.

Argument nr. 1 hænger sammen med ønsket om at vise barmhjertighed. Eller mere direkte: Det er indlysende, at tanken om at afhjælpe 
ubærlig lidelse med dødshjælp er begrundet i barmhjertighed over for det lidende menneske. Dødshjælp drejer sig dog ikke om at lindre og befri en patient for lidelse, for det er ikke at fjerne lidelsen fra en patient. Det er at fjerne den lidende. Dermed naturligvis også lidelsen, men dødshjælp slutter både den døendes biologiske og sociale liv (Materstvedt, 2012). Eller sagt med andre ord: foruden lidelsen fjernes erindringer, erfaringer, identitet og muligheden for at modtage smil, omsorg og kærlighed. ${ }^{1}$ Dødshjælp betyder noget godt for patienten, men derefter betyder patienten ikke noget (jf. Velleman, 1999).

Argument nr. 2 - respekt for selvbestemmelsesret - associerer til positive begreber som en fri vilje og frivillighed. I det følgende vil jeg se nærmere på især dette argument, fordi det i mine øjne udgør den stærkeste appel til vor tids mennesker.

\section{Respekt for selvbestemmelsesret - en kritisk analyse}

Selvbestemmelsesret synonymiseres med autonomi. Ordet er oprindeligt græsk og betyder »selvlov«. Autonomi, som det opfattes i dag, er autonomi på individniveau - en »individuel autonomi«. Oldtidens autonomibegreb gjaldt samfund og ikke individer. Græske byer var autonome, hvis de ikke var underlagt lovgivning fra andre byer. De lavede selv deres love, som gjaldt for det enkelte samfund. Autonomi havde retslig betydning for samfundet og var ikke det samme som individuel selvbestemmelsesret.

Begrebet individuel autonomi var endnu ikke så rodfæstet i 1948, at FN tog det med i sin Verdenserklæring om Menneskerettigheder. Set med vore dages øjne er det interessant, at det ikke blev nævnt eksplicit.

Man kan skelne mellem en minimalistisk individuel autonomi og en ikke-minimalistisk. Ved den minimalistiske autonomi skal enhver autonom beslutning, som en person træffer, respekteres, alene fordi den er autonom. Ved den ikke-minimalistiske autonomi bør en beslutning ske

\footnotetext{
Maleren Edvard Munchs kunstneriske manifest melder sig som et apropos: „Det skal ikke længre males interiører og folk som leser og kvinder som strikker. Det skal være levende mennesker der puster og føler og elsker og lider.«
} 
på et informeret og velovervejet grundlag. Det er den ikke-minimalistiske autonomi, som gælder i den danske sundhedslov.

I det følgende vil jeg omtale nogle facetter af autonomibegrebet i forbindelse med dødshjælp:

\section{Autonomi ifølge sundhedsloven}

Selvbestemmelsesretten er ifølge sundhedsloven et gennemgående, lovfæstet princip i varetagelsen af vore patienter. Men den drejer sig om patientens ret til - på et velinformeret grundlag - at sige nej til et behandlingstilbud. Det gælder et hvilket som helst behandlingstilbud, også selv om behandlingen er livsreddende. I den forstand er det habile menneskes selvbestemmelse ubegrænset.

Patientens ret til at afslå enhver behandling indebærer imidlertid ikke en ret til at $f a ̊$ enhver behandling, som patienten måtte kræve. Patienten har derfor ikke en ret til at forlange en hvilken som helst behandling, som medfører en andens pligt til at opfylde denne ret. I så fald ville autonomi være synonymt med autokrati, som kan oversættes med »selvets bestemmelse over andre«. Med andre ord, selv om patienten har ret til at afvise ethvert indgreb på sin krop og sjæl, har patienten ikke ret til at kroeve ethvert indgreb på sin krop og sjæl. Det er altså ikke en krænkelse af en patients selvbestemmelse at afvise et krav, denne måtte stille; der kan blandt andet være faglige grunde til ikke at opfylde en patients ønske. Man kan udtrykke det sådan, at lægen selv har autonomi og derfor også kan sige nej. Ifølge lovens beskrivelse af selvbestemmelsesretten ville det således ikke være en krænkelse af et menneskes autonomi at nægte at tage livet af det menneske.

2. Autonomiens konsekvens for muligheden for autonomi

I modsætning til sundhedslovens tankegang opfattes selvbestemmelsesret i bred almindelighed som en rettighed til at vælge og forlange. Men det menneske, som efter denne opfattelse stiller krav og vælger dødshjælp, afskærer sig endegyldigt fra sidenhen at kunne bestemme eller vælge noget som helst. Når det gælder døden, kan man kun bruge sin selvbestemmelsesret ved at afhænde den for stedse. Via sin autonomi vælger man med andre ord ikke mere at 
have autonomi. (Allerede filosoffen Immanuel Kant behandlede dette problem, se Matersvedt \& Bosshard, 2009.)

Filosoffen Jacob Birkler omtaler, at respekt for selvbestemmelsesretten refererer til en person, som respekteres: Men det er netop denne person, som forsvinder. Vi respekterer 'dig' ved at fjerne 'dig'. Respekten for selvbestemmelsen kan således betragtes som selvgendrivende« (Birkler, 2015, s. 85).

Det er analogt, at frihed ifølge filosoffen John Stuart Mill udelukker retten til frivilligt at blive en andens slave. Den amerikanske læge og etiker Daniel Callahan (1989, s. 5) citerer Mill: »By selling himself for a slave a person abdicates his liberty; he forgoes any future use of it beyond that single act ... The principle of freedom cannot require that he should be free not to be free. It is not freedom to be allowed to alienate his freedom «.

Idéhistorikeren Johannes Sløk var tilhænger af legalisering af dødshjælp, men fremsatte alligevel engang den betragtning, at dette valg ikke er som andre valg, fordi begrebet død ikke har noget indhold; død er det samme som ingenting, og man kan ikke vælge mellem liv og ingenting. Man må derfor snarere tale om et fravalg, man fravælger livet, uden at man derved tilvælger noget andet. Døden er ikke »noget andet« end livet; den er livets ophør eller tilintetgørelse.

3. Autonomi som mulig handlingsanvisning for dødshjolp

Dødshjælp involverer to menneskers selvbestemmelse og er derfor ikke blot en individuel handling. Det er selvmord derimod; selvmordet er noget individuelt, næsten privat. Dødshjælp er en handling, som kræver, at to mennesker gør det muligt - og at det i øvrigt godkendes i samfundets kultur og lovgivning.

Dødshjælp kræver således et andet menneskes moralske og fysiske hjælp. Det forpligter to mennesker, den der skal have dødshjælp, og den der skal hjælpe med det. Men vort samfund godkender ikke ellers drab som et forhold mellem to personer, som begge samtykker. Der findes undtagelser fra drabsforbudet, men det drejer sig om krig eller selvforsvar og begrundes aldrig med, at drabet udføres til en andens gavn. 
4. Autonomi som udtryk for en fri vilje

Alle væsentlige beslutninger, et menneske tager, sker i et eller andet forhold til andre. De beslutninger, vi tager, påvirker andre mennesker, og de påvirkes af andre mennesker.

Den amerikanske filosof og læge Daniel Sulmasy fremhæver, at der kan ligge et pres på en person med hensyn til at være i samklang med andre (2017). Social adfærd indpodes i os og bestemmer derpå vore autonome valg, siger Sulmasy. Hvis dødshjælp legaliseres i et samfund, vil de, som lider af kronisk sygdom eller har en dødelig sygdom eller er afhængige af andres hjælp, blive tilskyndet til at gå ind for ideen om dødshjælp og eventuelt bede om det, når det gælder dem selv. Patienten siger altså: »Doktor, nu må du hjælpe mig med at afslutte livet.« Og eftersom ordene kommer ud af patientens egen mund, opfattes anmodningen som autonom, hvor det i virkeligheden er en afspejling af, at også omgivelserne vurderer, at patienten er i en elendig tilstand. Sulmasy tilføjer (2017, s. 63): "Lægen indvilliger så i anmodningen, og på overfladen synes alt måske i orden, men der er sket et uheldsvangert brud i samfundets moralske grundfjeld langt nede under den rolige overflade.«

Den franske bioetiker Emmanuel Hirsch fremfører, at den individuelle autonomi kan være en illusion. Oversat af Nigel Biggar siger han, at en patient:

may truly want to die, but this desire is not the fruit of his freedom alone, it may be - and most often is - the translation of the attitude of those around him, if not of society as a whole which no longer believes in the value of his life and signals this to him in all sorts of ways. Here we have a supreme paradox: someone is cast out of the land of the living and then thinks that he, personally, wants to die. (Biggar, 2004, s. 148)

Autonomi i forbindelse med dødshjælp opfattes som overensstemmende med den ideologi, som gælder i vores liv. Vi opfatter, at vi er herrer over livet, og derfor kan vi også være herrer over døden. Vi mener, vi er beslutningsdygtige i alle sammenhænge. Visse beslutninger og valg kan naturligvis være svære at tage, men når det kommer til stykket, er det os selv, som tager dem. 
Men bortset fra at valget af egen død mere er et fravalg, som Sløk har påpeget (se ovenfor), er dette valg helt anderledes end de fleste andre valg, som sædvanligvis forbindes med begrebet autonomi. For beslutningen om ens egen død skal tages ikke i en dagligdags sammenhæng, hvor personen er i fuld kontrol over sit liv. Det hører ikke med til dagligdagens valg at ønske sin egen død. Det er et ønske, som opstår på baggrund af fortvivlelse og en følelse af håbløshed og ofte også en følelse af at være til overs. En sådan situation er et skrøbeligt grundlag for valg, men det ikke-syge menneske forestiller sig, at det er en beslutning, som man vil kunne tage, også når man er syg. Derfor kan de, der skal svare på spørgsmålet om dødshjælp i en meningsmåling, næppe forestille sig ikke at skulle kunne bestemme selv.

Valget af ens egen død er således anderledes end andre valg, som mennesker, der ikke er syge, kan gøre. Den svenske forfatter Carl-Henning Wijkmark tillægger i bogen "Stundande natten" (dansk: "Natten der kommer«) sin hovedperson følgende betragtning: »Et besynderligt paradoks kan det forekomme, men jo svagere jeg blev, jo mindre ville jeg dø. (Jeg håber, at tilhængere af dødshjælp er opmærksomme på dette fænomen, som jeg har en mistanke om er almindeligt)« (Wijkmark, 2013, s. 109).

Mennesker, som ikke er syge, forestiller sig ikke, at de kunne komme i situationer, hvor de ville ønske ikke at have den mulighed at skulle vælge. Men hvis dødshjælp var lovliggjort, ville muligheden ligge i alles bevidsthed - patientens, lægens, de pårørendes, plejepersonalets - også selv om det ikke blev direkte formuleret som et tilbud. Ifølge lovgivning og regler forestiller man sig, at patienten skal være fri til at kunne vælge dødshjælp, men patienten kan så netop ikke blive fri for at skulle vælge.

5. Autonomi i forbindelse med dødshjoelp skal udøves af sårbare mennesker

Hvis en lov om dødshjælp giver patienten en ret til at dø, vil det kunne opleves som en pligt til at dø. Der er også blevet argumenteret for, at pligtopfyldende mennesker ligefrem vil kunne ønske at påtage sig denne pligt, og at man ikke bør fratage dem den mulighed 
(Warnock, 2008). Hvad skal en patient lægge vægt på, når han eller hun skal beslutte ikke at ville leve længere? I andre af livets valgsituationer er det rigtigt at tage hensyn til andre, og det vil også gælde her. En »normal« hensyntagende adfærd vil kunne forstærke det $\mathrm{i}$ forvejen fortvivlede menneskes følelse af at være en byrde. »Hvor selvbestemmende kan de svageste handle, når omverdenen vurderer deres syge, afhængige og lidende liv som uværdigt? « spørger den norske teolog Knut Ruyter (1998, s. 182).

Den engelske praktiserende læge Iona Heath skriver i en klumme i British Medical Journal om den indirekte tvang, som kan ligge $i$ at give det sårbare og afhængige menneske dette valg:

It seems to me to be impossible to ensure that an apparently voluntary request for assisted dying is not in some small way coerced. It is all too easy for sick and disabled people to believe that they are becoming an intolerable burden to those closest to them, and indeed they often are a burden. In such circumstances a request for assisted dying can become a sort of sacrifice on the part of the dying person, with complicit, self interested support from relatives, professionals, or carers. (Heath, 2012, s. 35)

Man må derfor stille det spørgsmål, om alle valg skal være til rådighed. Der kan komme til at hvile et direkte eller indirekte pres på patienten for at vælge muligheden dødshjælp, hvis tilstanden i øvrigt vurderes som tilstrækkelig lidelsesfuld og håbløs, og livskvaliteten bedømmes som tilstrækkelig lav af patienten selv og af andre.

Vi er sårbare og afhængige af det fællesskab, vi er i. På den måde bliver vi aldrig fuldt autonome. Vi er fra fødslen sat ind i medmenneskelige sammenhænge i større eller mindre grad. Det gælder socialt, kollegialt, venskabsmæssigt og familiemæssigt.

De norske forfattere, Jan-Olav Henriksen og Arne Johan Vetlesen siger det på denne måde:

Det nyfødte menneskebarnet er fra første stund avhengig av at det er noen andre til stede - noen som sørger for næring, varme og trygghet. Avhengigheten av andre bunner i den enkeltes sårbarhet. Sårbarheten 
gjør at bånd etableres til andre. Uten bånd til noen utenfor seg selv, kan ikke mennesket klare seg. Mennesket er nemlig ikke et selvtilstrekkelig vesen, og mangelen på selvtilstrekkelighet gjelder ikke bare ved fødselen, det er snarere et vesenskjennetegn som vedvarer livet ut. (Henriksen og Vetlesen, 2006, s. 76)

\section{Autonomi som relativt begreb}

Autonomi respekteres dog ikke fuldt ud som begrundelse for dødshjælp. Hvis en læge skal udføre det, er det ikke tilstrækkeligt at henvise til patientens anmodning. Det kræves også, at patientens livsværdi vurderes som tilstrækkeligt lav også af omgivelserne. Det, der legitimerer dødshjælp, er således ikke alene, at der foreligger en anmodning, men at visse liv vurderes at være ikke-leveværdige.

En hollandsk læge fortalte mig, at han stiller mange og grundige spørgsmål til den patient, som har anmodet om dødshjælp. Han tilføjede: »Men det er ikke altid, jeg er tilfreds med patientens svar.« Det er med andre ord hans grad af tilfredshed, som er afgørende for, om dødshjælpen kan bevilges. Det fremstår naturligvis som en ansvarlig adfærd, men ret beset afvejer denne læge respekt for patientens autonomi imod, om han mener, patientens ønske er oprigtigt, om patientens liv er leveværdigt, og hvad der er barmhjertigt. Denne problemstilling blev allerede omtalt længe før fremsættelsen af den hollandske lov i sin tid (Jochemsen, 1994).

Hvis det på den anden side er barmhjertighed, der skal bære ideen om dødshjælp, følger spørgsmålet, om ikke også andre patienter, som lider, men som ikke kan bede om dødshjælp - for eksempel på grund af svækkelse eller demens, eller umyndige børn - burde kunne tages af dage (se også kap. 7). De har ikke autonomi, men de kan have lige så stor lidelse.

Når autonomiargumentet med andre ord ikke kan bruges, bærer lidelsesargumentet igennem. Det er ikke kun en forventelig logisk og psykologisk konsekvens, det er også en erfaring, at det går i den retning, idet udviklingen i lande, som har haft mange års praksis med dødshjælp, bekræfter det (se kap. 13). Nærmest ud fra et retfærdigheds- og lighedssynspunkt inddrages flere og flere patienter som kandidater til dødshjælp (MacKellar, 2017; Montero, 2017). I 
Holland debatteredes i efteråret 2019, om dødshjælp kunne udvides til også at gælde børn (Pedersen, 2019, s. 11). Nogle kalder det et spørgsmål om barmhjertighed, andre har henvist til FN's børnekonvention, som taler om barnets tarv.

\section{Konsekvenser for patient-læge-forholdet}

I det foregående afsnit har jeg diskuteret to hovedargumenter for en lovliggørelse af dødshjælp: At afhjælpe den ubærlige lidelse og at respektere selvbestemmelsesretten. Argumenterne er lette at følge, og det er i udgangspunktet gode argumenter. Ofte forenkles spørgsmålet imidlertid, og det betyder, at argumenterne fremstår som uimodsigelige. Det virker, som om de dilemmaer, som kunne ligge i spørgsmålet, forsvinder. Om forenklinger af etiske dilemmaer har den italienske filosof og forfatter Umberto Eco sagt:

Visse etiske problemer er begyndt at stå klarere for mig i kraft af mine overvejelser om nogle semantiske spørgsmål - og du skal ikke tage dig af, at der er nogle, der siger, at vi taler for svært. De er muligvis blevet opfordret til at tænke alt for nemt af massemediernes »åbenbaring«, som pr. definition altid er forudsigelig. De må lære at tænke svært, for hverken det gådefulde eller det åbenlyse er nemt. (Eco, 1998, s. 80)

I det foregående afsnit har jeg især problematiseret begrebet autonomi i forbindelse med dødshjælp. Som det er fremgået, skal patientens autonomi udøves i et intenst og kompliceret samspil med omgivelserne. I det følgende vil jeg se nærmere på den følsomme relation, der er mellem patient og læge, og endelig vil jeg pege på, at der netop i denne relation indgår elementer, som ikke uden videre lader sig veje og måle. Relationen benytter som sit sprog ikke alene hjernens, men også det vi kan kalde hjertets sprog.

\section{Normalisering af dødshjælp}

En lovliggørelse af dødshjælp vil ikke blot gøre handlingen mulig inden for lovens rammer, men også gøre den mulig i vores bevidsthed. Hvor 
dette at tage et menneske af dage grundlæggende har været en uacceptabel handling og i den forstand umulig, da det er en overskridelse af et tabu, vil en lovliggørelse medføre, at umuligheden og tabuet forsvinder. Men en videre konsekvens ville være, at det også kunne blive en forventet handling - grænsende til en moralsk forpligtelse - når man stod over for stor lidelse. Man har talt om, at en legalisering betyder, at der kan udvikles en »eutanasi-mentalitet«, eller at dødshjælp »normaliseres« (Ruyter, 1998; MacKellar, 2017).

Normalisering af dødshjælp kan være med til at forklare den såkaldte glidebane-effekt (MacKellar, 2017). Aristoteles tillægges ordene, „En handling bliver en vane, bliver et karaktertræk, bliver en skæbne.« Den aforisme formuleres mere nutidigt i en kronik af psykologen Frej Prahl:

Hvorfor mon stadig flere lag af afhængige mennesker kvalificerer til aktiv dødshjælp i Holland? Det er en naturlig konsekvens af den samme psykologiske mekanisme. Jo mere vi gør en bestemt handling, desto mere retfærdiggør vi, at de her mennesker ikke har noget at leve for. Jo mere vi retfærdiggør, at mennesker ikke har noget at leve for, desto flere mennesker vil efterhånden ikke have noget at leve for. Jo flere mennesker, som ikke har noget at leve for, desto flere potentielle modtagere af aktiv dødshjælp. (Prahl, 2016)

Man må endog stille det spørgsmål, om en lovliggørelse af dødshjælp vil skabe en slags afhængighed af muligheden. I sin bog »Being Mortal« skriver den amerikanske kirurg og forfatter Atul Gawande: »I fear what happens when we expand the terrain of medical practice to include actively assisting people with speeding their death. I am less worried about the abuse of these powers than I am about dependence on them « (Gawande, 2014, s. 244). Vil en lovgivning få os til at betragte lidende, handikappede og afhængige mennesker på en ny måde, nemlig at de mennesker måske kan undværes? (Prahl, 2016). Vi vil naturligvis henvise til, at det vil være til deres eget bedste (»in the best interest of the patient«), men kunne der være andre motiver? »'He would be better off dead' can be said for many dubious reasons: the most dubious is that we would be better off if he were dead«, skriver filosoffen David Jones (2017, s. 250).

En anmodning om dødshjælp er ganske sjælden i Danmark både på hospitalsafdelinger og i hospices - og langt sjældnere, end det kolporteres 
i medierne. Den ledende overlæge, Bente Sørensen, på kræftafdelingen på Vejle Sygehus sagde for et års tid siden til mig: »Jeg kan praktisk talt ikke mindes, at vi har haft en patient, hvor dødshjælp kom på tale. Det er slet ikke noget 'issue‘ på vores afdeling". Man må spørge, om det blandt andet kan skyldes, at dødshjælp ikke er "på dagsordenen", fordi det ikke er legaliseret. I for eksempel Belgien høres spørgsmålet jævnligt og nogle gange endda allerede på det tidspunkt, hvor en alvorlig diagnose stilles (Montero, 2017; Beuselinck, 2017).

Når dødshjælp ikke er lovliggjort, er det heller ikke nødvendigt, at det bliver en overvejelse i behandlingsforløbet. Hvis dødshjælp derimod var en mulighed, ville der opstå andre tanker - både nogle, som udtryktes og nogle, som ikke udtryktes. Er lægen patientens hjælper i livet, eller er han den, som kan tage livet af patienten, når visse betingelser er opfyldt? For det kunne være betingelser, som ikke kun var bestemt af patienten. Ville der bag kitlen kunne være skjulte motiver? Lægens rolle bliver tvetydig både for patienten og for lægen selv (se kap. 9).

Den hollandske læge og kardiolog Richard Fenigsen har været en vedholdende kritiker af sit lands mangeårige dødshjælpspraksis. Han fremhæver i et længere essay (Fenigsen, 1989), at patienter vil kunne ane, at den læge, der er parat til at ombringe dem, når de ønsker det, også vil være i stand til det, uden de ønsker det. Muligheden for dødshjælp vil således kunne skabe en relation, som præges af mistro og frygt.

Modsat fremføres det ikke sjældent, at det af frygt for fremtidig lidelse eller sygdomsprogression kan være en kilde til lettelse og oplevelse af kontrol at vide, at dødshjælp er en tilgængelig mulighed; det er beskrevet som en slags sikkerhedsventil, selv om de færreste i sidste ende gør brug af den (Wilson et al., 2007).

\section{Rationelle og irrationelle elementer i eksistentielle valg}

Patient-læge-forholdet bestemmes naturligvis ikke kun af rationel og logisk tænkning. Uafvejelige størrelser som følelser, kropssprog, medbragte holdninger og erfaringer fra det tidligere liv indgår - også erindringer om tidligere sygdomsperioder og patient-læge-kontakter. 
En læge på et dansk hospice fortalte mig om en patient, som havde bedt ham om at gøre en ende på elendigheden. Lægen havde svaret, at han ville hjælpe ham på alle måder, men at han ikke måtte tage ham af dage. Patienten sank tilbage i sengen med en lettelse og spurgte: "Hvad kan du da gøre for mig?" Hvordan kan det være beroligende for patienten, at lægen ikke må yde den dødshjælp, han bliver bedt om af patienten? Jeg tror, det hænger sammen med, at mennesker er sådan indrettet, at de - med et billede fra radiofoni - kan modtage og sende på både hjernen og hjertets bølgelængde. Den første er logisk og rationel, og her er et tilfredsstillende svar på patientens forespørgsel et »ja«. Den anden er ulogisk og irrationel, og her kan det rigtige svar være et »nej«.

Jeg husker en sætning, som illustrerer metaforen om hjernen og hjertets bølgelængde: En jurastuderende skrev i et brev til sin udkårne: »Med hensyn til mine følelser for dig henviser jeg til tidligere korrespondance herom." Det viser, at når vi stiller ind på de to bølgelængder samtidigt, bliver det enten uforståeligt eller i det mindste pudsigt. Hos mennesket veksler de to bølgelængder imidlertid. Hvis vi skulle bruge hjernens logik i hjertets anliggender, ville vi blive skeptiske. Hvis vi kunne måle og beregne kærligheden, ville vi ikke regne den for noget. En logisk absurditet for hjernen kan godt forstås på hjertets bølgelængde. Et eksempel på en ulogisk sætning, som alligevel giver mening, er: »Kun fordi jeg har dig, kan jeg blive ved at klare de problemer, som du uvoegerligt giver!" Det er logisk set et paradoks, men på hjertets bølgelængde kan det blive opfattet som en kærlighedserklæring.

Hjernens og hjertets bølgelængde. En tilsvarende metafor er hjerne- og hjertesprog. Det er ikke mig, der har »opfundet« de betegnelser, men jeg har brugt dem nogle gange (for eksempel Hartling, 2001). Der er mange eksempler på de to sprog - og uden tvivl flere, end vi tænker over til daglig. Bedstemor fortæller ikke børnebørnene eventyr om græssets beskaffenhed, dets cellulose- og vandindhold, men om elverpigerne, der danser på græsset. Hjernesprog ville eliminere fortryllelsen i eventyret. Tårer er ikke blot $\mathrm{H}_{2} \mathrm{O}$ med lidt $\mathrm{NaCl}$ i. Morgendug glimter som diamanter i edderkoppespindet, men beskrivelsen bliver flad, hvis man kun taler om kondenseret vand. 
Hvis ikke mennesket havde begge sprog, ville vi ikke kunne forstå poesi eller kunst. Men selv om vi véd, at begge sprog er vigtige, glemmes det ofte - også i debatten om dødshjælp.

For at belyse de to sprog i denne forbindelse henviser jeg til et uddrag af min bog om dødshjælp (Hartling, 2015; se tekstboks), hvor jeg fortæller om en personlig oplevelse i forbindelse med min hustru Katrines sygdom. Hun døde i 2012.

Katrines naturlige brune lød var blevet gusten, som det kan ses hos patienter med kronisk nyresvigt. Grålig i farvetonen som om solbrændtheden havde fået et lag askestøv over sig. Dialyserne var opslidende, men livsnødvendige. Og de var blevet nødvendige hver anden dag. Fire-fem timers dialyse. Pause den følgende dag. Og så igen. Op mod en dialyse begyndte væskeophobningen at plage. Vejrtrækningen blev besværet, og der var trykken for brystet.

$[\ldots]$

De første mange timer efter en dialyse var hun umådelig træt på grund af kroppens reaktion over for de væskevolumener, der blev »flyttet« og renset, og på grund af den hurtige reduktion af kroppens væskevolumen. Derefter var der nogle få timer med nogenlunde velbefindende, hvis ikke der var kvalme eller hovedpine. Man kunne kalde det en oase af velbefindende mellem dialyserne. Frygten for næste dialyse afløstes gradvist af en længsel efter den på grund af det tiltagende væskepres med åndenød og belastning af hjertet.

$[\ldots]$

Katrine var et menneske med stort livsmod. Mange har det i tidens løb hjulpet ud over hende selv. I den sidste tid fik medpatienter hjælp og støtte og gennem Katrine en stærk fortaler. For eksempel når de ikke selv kunne formulere en modstand mod en krænkelse, som kunne være halvskjult i venlig tale om regler og muligheder. Men selv hun kunne knækkes. Græd om natten i sin hospitalsseng - af ensomhed, udmattelse og af savn. 
Hun længtes så meget efter almindelige dage uden smerter og kvalme, men der var kun få af dem. Og der var en overvældende vished om, at der ikke var udsigt til bedring. "Jeg véd, hvad jeg kan gøre, « siger hun en dag, »jeg har tænkt over det. Vil du høre det?» Jeg nikker forsigtigt. Hendes øjne hviler på mig. Hun er alvorlig. »Jo, en nat åbner jeg for mit dialysekateter. Det kan godt lade sig gøre; de ser ikke så meget til mig om natten. Blodet vil langsomt dryppe ud. På grund af A-K-behandlingen vil det ikke stoppe. Jeg vil langsomt falde i søvn ... Nej, nej - når du ser sådan på mig, gør jeg det ikke.»

Den oplevelse, der er gengivet i tekstboksen, illustrerer de to tænkemåder - den rationelle og den irrationelle. Hvis jeg kun tænkte rationelt, måtte jeg erkende, at hun som beskrevet havde det forfærdeligt, og at situationen var udsigtsløs. Med hjernesproget kunne jeg ganske fornuftigt have svaret hende: »Jeg forstår dig. Det er en rigtig beslutning. Du skal have lov at slippe nu. Jeg vil sidde hos dig, mens det sker. Du skal ikke vare alene."

Men hjertesproget fandt ikke de ord. Det kan kun udtrykke en sorg over tanken om at skulle miste den elskede. Kærligheden er på den måde egoistisk, men hvis det er egoisme, kunne hun ikke se det som egennytte. Hun så og hørte det, hun havde brug for, og sagde næsten uden pause fra sine første ord - afbrød nærmest sig selv: »Nej, når du ser sådan på mig, gør jeg det ikke!»

Katrine tænkte på at tage sit liv for sin egen skyld og ville så ikke gøre det for min skyld. Eller måske netop også for sin egen skyld. Fortalte hun mig om sin plan for at se min reaktion? Gav det hende styrke og livsmod, at reaktionen ikke var rationelt imødekommende? Og havde den været rationelt imødekommende, ville hun da måske have gennemført sin fortvivlede plan.

Min oplevelse understreger, at »intet menneske er en ø« (jf. et berømt digt af John Donne fra 1624), og at ingen alvorlige beslutninger tages "uden hensyn", fordi ingen beslutninger kan tages adskilt fra de relationer, vi har. Men det er ikke den vigtigste pointe her, for Katrine lærte mig noget, som ikke er fremtrædende i tidens debat om dødshjælp, nemlig 
dette, at det fortvivlede menneske ikke kun har brug for at blive mødt med en rationel forståelse for, at nu er det bedst at komme af dage. Det skyldes, at den forståelse på samme tid rummer et element af, at det medmenneske kan undværes. Respekt for selvbestemmelsesretten understreges igen og igen i dødshjælpsdebatten, men den respekt kan rumme en uudtalt og indirekte afvisning eller udelukkelse (forstødelse).

Dette gælder nemlig ikke kun, når det er en af de allernærmeste. Jeg er ikke i tvivl om, at det også vil gælde en mere fremmed - for eksempel en patient. Hvad hører (ser og mærker) patienten, som i sin nød og med henvisning til sin selvbestemmelsesret anmoder om dødshjælp? Patienten mærker og forstår, at han eller hun kan undværes, og det har intet menneske brug for at mærke. Patienten føler sig måske allerede til overs, og den følelse forstærkes, når patienten rationelt vælger, at nu skal det slutte, og når omgivelserne rationelt svarer, at det er der al mulig grund til. På den måde kan patientens følelse af håbløshed blive større og endda begrunde og fremskynde valget af dødshjælp.

Lad mig sige det med andre ord: I et land med lovliggjort dødshjælp bliver budskabet: "Du beder om din død. Det er til at forstå, du har en uborlig tilstand, og vi kan ikke gøre så meget mere. Men du må overveje det nøje. Jeg vil komme igen for at høre, om du fortsat mener det. (Anmodningen skal efter reglerne være vedholdende). Jeg må også foreloegge det for en kollega, før vi kan skride til en sådan handling." (En uafhængig kollega skal høres for at være med til at fastslå, at situationen er udsigtsløs, og at patienten mener det). Svaret er ansvarsbevidst og bygger på en velment vurdering af, hvad der er bedst for patienten. Men samtidig kommer svaret til at rumme: „Vi kan hjoelpe dig herfra, for vi kan også godt undvoere dig, sølle som du er. Vi kan blive af med dig«. Så hjerteløst er der ingen, der taler, men hvad hører patienten - midt i sin elendighed - i det behjertede tilbud om dødshjælp?

I et land med et opretholdt forbud mod dødshjælp kunne budskabet lyde: »Du beder om din død. Det er til at forstå, for du har det forfoerdeligt. Vi vil gøre, hvad vi kan for dig, og vi vil vere hos dig, også nu hvor det er så slemt.« Patienten vil måske gentage sit ønske om at $\mathrm{d} \varnothing$, men den endelige barriere i loven behøver ikke, som det af og til siges, være ubarmhjertig, men kan være et tilsagn til patienten om, at vi tør være sammen med ham 
eller hende i magtesløsheden, og at de fortsat må være i fællesskabet, som dette liv er. Når patienten beder os om hjælp til at dø, må vi lytte på både hjernens og hjertets bølgelængde.

\section{Referencer}

Beuselinck, B. (2017). 2002-2016: Fourteen years of euthanasia in Belgium. First-line observations by an oncologist. I D. A. Jones, C. Gastmans, C. MacKellar (Red.), Euthanasia and assisted suicide. Lessons from Belgium (s. 101-113). Cambridge: Cambridge University Press.

Biggar, N. (2004). Aiming to kill. The ethics of suicide and euthanasia. London: Darton, Longman and Todd.

Birkler, J. (2015). Døden i et professionelt perspektiv. De svoere valg. København: Nyt Nordisk Forlag Arnold Busck.

Callahan, D. (1989). Can we return death to disease? Hastings Center Report, 19 (suppl.), 4-6.

Chesterton, G. K. (1937). Euthanasia and murder. The American Review, 8(4), 487-490.

Donne, J. (1624). Meditation XVII. Devotions upon emergent occasions and several steps in my sickness.

Eco, U. (1998). Moralske tanker. København: Forum.

Fenigsen, R. (1989). Mercy, murder and morality perspectives in euthanasia: A case against Dutch euthanasia. Hastings Center Report 19 (suppl.), 22-30.

Gawande, A. (2014). Being mortal. London: Profile Books.

Godfredsen, E. (1964). Medicinens Historie. 2. udg. København: Nyt Nordisk Forlag.

Hartling, O. J. (2001). Men størst af dem ... I T. Lindhardt (Red.), Det tror vi på. 20 danskere om tro, verdier og livsgrundlag. Sesam.

Hartling, O. J. (2015). Aktiv dødshjelp. Kan vi mere, end vi kan magte? København: Gyldendal.

Heath, I. (2012). What's wrong with assisted dying. BMJ, 344, 35 .

Henriksen, J.-O. \& Vetlesen, A. J. (2006). Norhet og Distanse. Grunnlag, verdier og etiske teorier i arbeid med mennesker. Oslo: Gyldendal.

Jochemsen, H. (1994). Euthanasia in Holland: An ethical critique of the new law. Journal of Medical Ethics, 20, 212-217.

Jones, D. A. (2017). Euthanasia and assisted suicide in Belgium. Bringing an end to interminable discussion. I D. A. Jones, C. Gastmans, C. MacKellar (Red.), Euthanasia and assisted suicide. Lessons from Belgium (s. 235-257). Cambridge: Cambridge University Press.

MacKellar, C. (2017). Some possible consequences arising from the normalisation of euthanasia in Belgium. I D. A. Jones, C. Gastmans, C. MacKellar (Red.), 
Euthanasia and assisted Suicide. lessons from Belgium (s. 219-234). Cambridge: Cambridge University Press.

Materstvedt, L. J. (2012). Intention, procedure, outcome and personhood in palliative sedation and euthanasia. BMJ Supportive \& Palliative Care, 2(1), 9-11.

Materstvedt, L. \& Bosshard, G. (2009). Euthanasia and physician-assisted suicide. I G. Hanks, N. Christakis, M. Fallon, S. Kaasa \& N. Cherny (Red.), Oxford textbook of palliative medicine, 4th edition (s. 304-319). Oxford: Oxford University Press.

Montero, E. (2017). The Belgian experience of euthanasia since its legal implementation in 2002. I D. A. Jones, C. Gastmans, C. MacKellar (Red.), Euthanasia and assisted suicide. Lessons from Belgium (s. 26-48). Cambridge: Cambridge University Press.

Pedersen, B. (2019, 29. oktober). Dødshjælp i Holland: Børnelæger vil udvide loven til børn under 12 år. Kristeligt Dagblad.

Prahl, F. (2016, 22. september). Frit valg til aktiv dødshjælp er en myte. Politiken.

Ruyter, K. W. (1998). Menneskeverd contra »menneskelig verdighet«? Norsk Teologisk Tidsskrift, 99, 181-96.

Sulmasy, D. P. (2017). Ethics and the psychiatric dimensions of physician-assisted suicide. I D. A. Jones, C. Gastmans, C. MacKellar (Red.), Euthanasia and assisted suicide. Lessons from Belgium (s. 49-64). Cambridge: Cambridge University Press.

Velleman, J. D. (1999). A right of self-termination? Ethics, 109, 606-628.

Warnock, M. (2008). A duty to die? Omsorg, 25(4), 3-5. Hentet fra http://eideforlag. no/filarkiv/Mary\%2oWarnock.pdf

Wijkmark, C-H. (2013). Natten der kommer. Nordstedts.

Wilson, K. G., Chochinov, H. M., McPherson, C. J., Skirko, M. G., Allard, P., Chary, ... Clinch, J. J. (2007). Desire for euthanasia or physician-assisted suicide in palliative cancer care. Health Psychology, 26, 314-323.

\section{Ordforklaringer}

adfærd: beteende $(\mathrm{S})$, atferd $(\mathrm{N})$

afvisning: avvisande (S), avvisning $(\mathrm{N})$

barnets tarv: hensynet til(l) barnet $(\mathrm{S} / \mathrm{N})$

elverpigerne: alveflickorna $(\mathrm{S})$, alvejentene $(\mathrm{N})$

endegyldig: oåterkallelig $(\mathrm{S})$, ugjenkallelig $(\mathrm{N})$

for stedse: för/for alltid (S/N)

hvornår: när $(\mathrm{S})$, når $(\mathrm{N})$

ikke måtte: Inte kunde (S), ikke kunne (N)

jurastuderande: juridikstuderande (S), jusstudent (N)

kitlen: läkarrocken (S), legefrakken (N) 
klumme: inlägg (S), innlegg $(\mathrm{N})$

måle: mäta $(S)$

nemt: lätt/lett (S/N)

opslidende: utmattande/utmattende $(\mathrm{S} / \mathrm{N})$

på overfladen: ytligt $(\mathrm{S})$, på overflaten $(\mathrm{N})$

ryge: röka $(\mathrm{S})$, røyke $(\mathrm{N})$

selvgendrivende: självförgörande $(\mathrm{S})$, selvmotsigende $(\mathrm{N})$

sundhedsloven: hälsolagen (S), helseloven (N)

ubærlig: outhärdligt $(\mathrm{S})$, uutholdelig $(\mathrm{N})$

udskyde: fördröja (S), utsette (N)

uheldsvangert brud: ödesdigert brot $(\mathrm{S})$, skjebnesvangert brudd $(\mathrm{N})$

vedholdende: ihållande $(\mathrm{S})$, vedvarende $(\mathrm{N})$

vejrtrækningen: respirationen $(\mathrm{S})$, åndedrettet $(\mathrm{N})$ 



\title{
Autonomi er noget vi giver hinanden
}

\section{Christian Juul Busch}

\author{
Hospitalspræst ved Rigshospitalet, København
}

\begin{abstract}
The concept of autonomy is essential in the discussion of assisted dying. In this chapter I will endeavour to nuance the concept of autonomy towards also encompassing an essential element of mutual commitment. Thus, the chapter will emphasise the importance of strengthening a nuanced concept of autonomy that I consider to be essential. Therefore, I will try to take the argument about the individual's right to decide over his or her own life as a starting point to investigate autonomy and assisted dying. In the common understanding of autonomy, the mutual obligation towards the community seems to be reduced in favour of the individual's right to decide for himself/herself. I will illustrate this aspect with an example from the world of cinema, Bille August's Stille hjerte (Silent Heart).
\end{abstract}

Keywords: assisted dying, autonomy, community, euthanasia, mutual commitment

\section{Etikkens grundspørgsmål}

Der er en bagside ved udviklingen af den moderne medicin. Det er et gode, at flere og flere patienter med alvorlige sygdomme lever længere og bedre med deres sygdomme. Men det betyder også, at uhelbredeligt syge og døende patienter kan føle sig fanget i et dilemma mellem på den ene side at fortsætte behandling og på den anden side frygten for ikke at kunne undslippe lidelsen. Det giver uhelbredeligt syge mennesker mange overvejelser over, hvornår "nok er nok«. Fordi frygten for at havne i en blindgyde af fortsat behandling uden kontrol over eget liv er så stor, bliver diskussionen om patientens selvbestemmelse, autonomien, naturligvis central.

Sitering av denne artikkelen: Busch, C. J. (2020). Autonomi er noget vi giver hinanden. I M. A. Horn, D. J. H. Kleiven \& M. Magelssen (Red.), Dødshjelp i Norden? Etikk, klinikk og politikk (Kap. 6, s. 125-139). Oslo: Cappelen Damm Akademisk. https://doi.org/10.23865/noasp.96.ch6.

Lisens: CC BY 4.0. 
Filosoffen og teologen Peter Kemp stiller den medicinske etiks grundspørgsmål, når han spørger: »Hvor går grænsen mellem det gode liv med teknologien og den destruktive anvendelse af den?« og han konstaterer: »Alt eller intet holdningen er ofte etisk fejhed, « og fortsætter: »Men ved at opgive spørgsmålet, fordi svaret er vanskeligt, opgiver man selve etikken, modet til at vælge mellem godt og ondt, som er selve modet til at leve« (Kemp, 1994).

For mig gælder Peter Kemps holdning også ved dødshjælp og i forhold til autonomi. Det er på ingen måde enkelt at afgøre, hvilken betydning den enkeltes ret til at bestemme over sit eget liv skal have, og hvilken betydning omgivelserne, de nærmeste pårørende skal have i valget om at ville leve eller dø. For mig gælder det om at finde den »vanskelige midte« mellem alt og intet holdningen og samtidig opretholde »modet til at vælge mellem godt og ondt, som er selve modet til at leve«. Et eksempel på vanskeligheden ved at vælge mellem retten til selvbestemmelse og pligten til at vægte hensynet til omgivelserne ser jeg udfoldet i filmen Stille hjerte.

\section{"Stille hjerte»}

I filmen Stille hjerte af Bille August lader han Esther, en kvinde på omkring 6o-65 år, der lider af den dødelige sygdom amyotrofisk lateral sklerose (ALS), fremsætte ét eneste ønske. Hun vil have en værdig død på et tidspunkt, hvor hun stadig kan genkende sig selv og er ved sine fulde fem. Det er hendes mand, lægen Poul, der skal gøre den dræbende dosis af piller klar til hende. Hendes problem er blot, at hendes ønske er et ulovligt ønske.

Parrets to døtre, Heidi og Sanne, bliver inviteret til familiens landsted for at tage afsked med deres mor. På forhånd ved de, at moderen har besluttet, at hun vil afslutte sit liv, når de tager hjem efter weekenden. Esther ønsker ikke at miste sin værdighed. Da hendes arm er begyndt at svigte hende, og hun taber ting, kan hun se i øjnene, at fra nu af vil sygdommen eskalere, og hun vil blive yderligere svækket, indtil hun dør.

En person mere, Lisbeth, Esthers gamle veninde gennem hele livet, er inviteret med til afskeden med Esther. Da Heidi, den ældste datter, 
opdager, at hendes far, Poul, har et forhold til Lisbeth, tilkalder Heidi en ambulance for at forpurre moderens død som reaktion på faderens forræderi overfor moderen. Da det går op for familien, hvad Heidi har sat i gang, viser det sig, at det er Esthers eget ønske, at Poul og Lisbeth danner par, fordi Poul ikke egner sig til at være alene. Den kaotiske situation med en ambulance på vej på grund af en misforståelse opløses ved, at den psykisk sårbare Sanne, der har tidligere selvmordsforsøg bag sig, redder situationen og lader som om, at det er hende, der er brudt sammen og har forsøgt selvmord, hvorefter hun springer ind i ambulancen og bliver kørt bort fra den kaotiske scene.

Da weekenden er ved at være forbi, og de øvrige forlader landstedet, ser man Poul holde pilleglasset og vandglasset, og Esther tager selv de piller, Poul har fremskaffet til hende. Derefter går Poul i slutscenen ud ad hoveddøren for at lufte hunden.

Formelt har alle accepteret Esthers beslutning, men reelt er beslutningen langt fra accepteret, så vidt jeg kan se. Det er hele tiden omdrejningspunktet i filmen, at når Esther selv har valgt at afslutte sit liv, så kan ingen for alvor anfægte Esthers valg, selvom de er i oprør over beslutningen. Esther er som figur tegnet som en stærk, selvstændig kvinde med klare meninger. Selv hun, der er så stærk, siger et par gange i filmen, at hun er i tvivl om sin beslutning, men at det er for sent at gøre den om.

\section{Når hjertet ikke er stille}

Esthers beslutning sætter så meget oprør i familierelationerne, at man mærker de følelsesmæssige bølger som nogle, der er ved at få familien til at drukne. Det er netop dét, der undrer mig og kalder på min opmærksomhed i forhold til filmen og tanken om autonomi og dødshjælp som sådan. Når vi er så forviklede i hinandens liv, som det smukt og særdeles realistisk beskrives i denne film, så undrer det mig, at Esthers selvbestemmelse, autonomi, bliver beskrevet som så rigid og så meget baseret på hensynet til Esther selv, at selv de voldsomme reaktioner ikke giver anledning til »second thoughts«. Når den »stærke» Heidi bryder sammen og mister overblikket, krakelerer og tilkalder en ambulance, så får det ingen konsekvenser for Esthers beslutning. Heller ikke når krisen 
med de »blå blink«, advarselslamperne, forstærkes yderligere, ved at den »skrøbelige« Sanne forlader sceneriet og går ind i ambulancen - med et prætenderet selvmordsforsøg som udgangsreplik, giver det anledning til forandringer i Esthers beslutning.

Når Esther har truffet sin beslutning, synes intet at kunne ændre den, hverken Esthers egen tvivl, der overhøres af hende selv og alle de øvrige, og heller ikke de voldsomme reaktioner, hendes beslutning sætter gang i. Det er interessant og tankevækkende, at ingen synes at kunne påvirke eller sætte spørgsmålstegn ved Esthers selvbestemmelse, autonomi, så den bliver diskuteret.

En passant kan man sige, at når Esther ikke selv reagerer på de voldsomme følelser, hendes beslutning sætter i gang i hendes døtre, kan det skyldes, at Esther har svigtende empatiske evner. ALS-sygdommen kan være associeret med demens (af frontotemporal type). Omkring halvdelen af ALS-patienter viser tegn på reduceret empati, bliver mere eller mindre apatiske, mister sygdomsindsigt, situationsfornemmelse og evnen til at overskue opgaver og træffe beslutninger (Schelde, 2016). Det kunne være årsagen til, at Esther ikke reagerer på, at Helle bliver opbragt over hele situationen og tilkalder en ambulance for at forpurre moderens forsæt, eller at den skrøbelige Sanne bliver nødt til at forlade huset. I filmen er der dog ikke noget andet, der tyder på, at Esther er ramt af manglende empati eller apati med relation til demens.

\section{Autonomi og gensidigt ansvar i selvets epoke}

Filmen gør det nærliggende at diskutere selvbestemmelsen, autonomien. Filmen bliver, som jeg tolker den, et vidnesbyrd om, hvordan hensynet til egne ønsker har større vægt end det gensidige hensyn til andre i den epoke, vi befinder os i. Autonomi er med rette en basal værdi, der ligger til grund for sundhedslovgivningen i alle vestlige lande. Selvom virkelighedens daglige beslutninger i behandlingssituationer ofte er baserede på et nært samvirke mellem patient og pårørende så er sundhedslovgivningen baseret på at sikre det enkelte menneskes integritet og autonomi gennem behandling og pleje. På den måde er Bille Augusts beskrivelse af epokens måde at se på autonomi på som udtryk for den enkeltes principielle ret 
til at udøve kontrol over eget liv og sygdom, uafhængig af omgivelsernes $ø$ nsker og præferencer, meget korrekt. Vi er i »selvets epoke«. Her er det enkelte menneskes egen følelse den højeste "autoritet«. "Only do what your heart tells you!« som Prinsesse Diana udtrykte det som et ekko af tidens væsentligste værdier.

Jeg mener, det i mange netværk kan være vanskeligt at udtrykke andre perspektiver end blot at understøtte et svært sygt og døende menneskes ønske. I forlængelse af dette rejser sig et spørgsmål. Er det overhovedet muligt for Heidi, Sanne og deres far for alvor at tale imod Esthers ønske om at dø? Filmen er så meget en film på epokens præmisser, at den mulighed end ikke afprøves som et samtaleemne. Men skiftevis markerer døtrene indirekte en klar uenighed med moderens beslutning, uden at det kommer klart og direkte til udtryk som en dialog.

På tidens vilkår gør Esther fordele og ulemper op ved at leve videre med sygdommens belastninger og det accelererende kontroltab og træffer sin beslutning. Gennem sin egen fornemmelse for, hvad der er værdigt, anser hun døden for mindre slem end livet med yderligere kontroltab og magtesløshed. I andre tilfælde end Esthers kan der være tale om uudholdelige smerter, som ikke kan lindres. I filmen fokuseres udelukkende på, at fra nu af vil Esthers sygdom progrediere, men der gøres ingen overvejelser over andre muligheder, for eksempel hvilke muligheder palliation og hospice kunne yde i en sådan sammenhæng, og i yderste tilfælde for eksempel palliativ (lindrende) sedering (se kap. 10).

Min hovedantagelse er, at vi i mange sammenhænge skal have retten til at bestemme over vores eget liv, når det ikke påvirker andre mennesker eller samfundet væsentligt. Samtidig ser jeg mennesket som reelt $i k k e$ værende et selvberoende væsen. Tværtimod er vi i højere grad, end tidens dominerende tanker tilsiger, afhængige af de sociale sammenhænge, som vi befinder os i, og påvirkes af både vores omgivelser og samfundet i den måde, hvorpå vi udøver vores selvbestemmelsesret, vores autonomi. Vi er forviklede i hinandens liv i højere grad og mere væsentligt, end diskussionen om dødshjælp og autonomibegrebet indikerer. Filmen Stille hjerte viser forbilledligt, hvor mange komplekse følelser Esthers beslutning sætter i gang i familien, uden at de komplekse følelser får nogen betydning for Esthers beslutning. 


\section{Autonomi er noget vi giver hinanden}

Efterladtes sorg forholder sig ikke alene til den efterladtes egne indre minder, følelser og tanker, men også til de forventninger, omgivelser, venner og kolleger og samfund har til den sørgende, og de privilegier, den efterladte tildeles for sin sorg. I en artikel om efterladtes sorg, set ud fra en socialkonstruktivistisk vinkel, beskriver Mogensen (2019), hvordan den sørgende har lod og del i et familiesystem, et bredere lokalt system og et samfundsmæssigt system, hvor den sørgende indgår med privilegier og forpligtelser.

Et tilsvarende perspektiv kan man anlægge for mennesker med alvorlige sygdomme og døende. I almindelighed fordrer de sociale netværk, vi indgår i, og vores forhold til samfundet, at mennesker med alvorlige, livstruende sygdomme tilkendes vidtrækkende privilegier, som frisætter den syge fra mange af de almindelige forpligtelser i gensidigheden med familien, omgivelserne og samfundet. Den syge og døende person bliver ikke mødt med mange traditionelle forventninger, men er ofte frigjort fra arbejde og hjemlige forpligtelser. Mange svært syge og døende bryder sig ikke om at være en belastning for omgivelserne og at være afhængig af omgivelsernes omsorg og pleje.

Der er ingen tvivl om, at en af de væsentligste årsager til at anmode om dødshjælp, er, at den uhelbredeligt syge føler sig til besvær for sine omgivelser, familie, venner og samfund. Det har været vist i undersøgelser, siden de første undersøgelser om dødshjælp blev lavet i begyndelsen af 1990'erne (Van der Maas, van Delden, Lijnenborg \& Looman, 1991). I de seneste registreringer af årsager til at anmode om lægeassisteret selvmord i Oregon var det i $201854 \%$ af patienterne, der delvist var motiverede til at vælge dødshjælp af frygt for at være en byrde for andre. Endvidere er andelen af patienter motiverede af tab af autonomi og faldende evne til at deltage i aktiviteter steget siden 1998 (Oregon Health Authority, 2011; 2019; se også kap. 14).

Graden af selvbestemmelse, som et individ gives og forventes at udøve, kan man kalde for en "rolle" $i$ det sociale, som et individ indtager i forhold til og forhandler med sine omgivelser. Omgivelsernes tilladelse eller fornægtelse af selvbestemmelsen får betydning for, hvordan det enkelte individ vil udfolde sin selvbestemmelse eller endda kan føle sig tvunget at 
udøve sin selvbestemmelse indenfor nogle rammer, der ligger i tiden frem for i det enkelte individ selv. Jeg mener, at det er væsentligt at fremhæve, at autonomi ikke alene er en tanke eller en følelse inden i den syge, men at forståelsen af selvbestemmelse også er noget, der er til stede mellem det enkelte individ og de mange relationer, den syge indgår i, og de normer, der er om selvbestemmelse i epoken. Mit indtryk er, at den svært syges og døendes »sidste vilje« er umulig at diskutere og stille spørgsmål ved for de pårørende. Selvom der måtte være massiv uenighed eller supplerende tanker og følelser blandt de pårørende, er det umulig at diskutere en tanke, der har karakter af en »sidste vilje«, med den døende. Den syges og døendes »sidste vilje« har karakter af et »helligt udsagn«.

I Stille hjerte præges Esthers selvbestemmelse af, hvordan omgivelserne tildeler hende ret til at udfolde denne. Prægningen viser sig i, i hvilken grad omgivelserne forstår, spørger ind til og taler om Esthers ønske om at bestemme over sig selv og herigennem anerkender Esthers ret til at handle ud fra sit autonome ønske og vilje. Autonomi er noget, vi giver Esther lov til at have eller ikke giver hende lov til at have i forhold til omgivelsernes tanker og normer. Autonomien får sit udtryk i forhold til den ret til at udfolde selvbestemmelsen, som den syge tildeles.

Ligesom man kan tale om, at den sørgende har nogle adgangsbetingelser og privilegier for at udfolde sin sorg, tildeles man som syg også nogle adgangsbetingelser og privilegier for at udfolde sin selvbestemmelse. Esthers privilegium er, at hendes »sidste vilje« om at afslutte sit liv er en "joker«, der matcher alle andre hensyn, også døtrenes uenighed i moderens beslutning. Autonomi er "noget, vi giver hinanden«, og det vil også være præget af de normer og kulturelle særpræg, som tiden er fuld af.

\section{Autonomi og moderniteten}

En af de normer, der er tydelige i den epoke, vi befinder os i i dag, og som Esther gestalter i filmen Stille hjerte, er, at det gælder om ikke at være til besvær, og at sygdom er svaghed. Man kan spørge sig selv, hvorfor det er sådan, og hvorfor vi ikke i så høj grad ser det som vores opgave at løfte og bære livets tunge vilkår sammen? Jeg kan ikke se bedre, end at i selvets epoke er en patient i bund og grund et individ, der har ansvaret for sit eget 
liv. Selvbestemmelseskulturen, der har manifesteret sig i selvets epoke, har fokuseret på at beskrive mennesket som selvstændigt og uafhængigt. Afhængighed og sårbarhed ses som en svaghed eller som en defekt.

Forskere som den belgiske professor i omsorgsetik Carlo Leget nævner, at selvbestemmelseskulturens udvikling gennem de sidste 30 år har været parallel med og er fostret af fremkomsten af neoliberalismen. Ifølge denne ideologi betragtes individuel frihed som den vigtigste sociale værdi. Som følge heraf bliver enkeltpersoner mere og mere set som entreprenører, der skal forme deres egen individuelle eksistens og er ansvarlige for deres eget liv (Leget, 2007, s. 81).

\section{Findes der et særligt skandinavisk begreb om autonomi med fællesskabet som centrum?}

Jeg vil rejse spørgsmålet, om der findes et særligt skandinavisk begreb om autonomi, som er helt anderledes og kontrasterer en holdning præget af moderniteten og selvbestemmelseskulturen? I en nordisk, skandinavisk forståelse er den enkeltes ret til at bestemme over sig selv og sit eget liv i høj grad flettet sammen med ansvaret for at tage hensyn ikke blot til sine nærmeste, men til hele samfundet som fællesskab.

Etisk råd beskrev i deres redegørelse om dødshjælp det således:

I vor kulturtradition er det dog grundlæggende, at intet enkeltindivids behov og $ø$ nsker kan være eneafgørende for, hvad selvbestemmelsesretten bør omfatte. Hos den enkelte værdsætter vi ikke bare evnen til at tage selvstændig stilling, men også evnen til at gøre dette under ansvarlig afvejning af de givne omstændigheder. I denne afvejning er det ikke blot vigtigt, at selvbestemmelsen udøves til vedkommendes egen gavn, men også til fællesskabets bedste. Herunder lægges der overordentlig stor vægt på, at ingen skades, det anses for ønskeligt, at andre så vidt muligt hjælpes, og tillige spiller lighedshensyn en betydelig rolle. (Det etiske råd, 1996, s. 119)

Endvidere bringes et citat af Göran Hermerén, hvor han giver udtryk for, at

Yderst få, om overhovedet nogen, beslutninger truffet af et menneske påvirker ikke nogen anden. Dermed aktualiseres spørgsmålet om selvbestemmelsens 
grænser og afvejningen af selvbestemmelsen mod andre værdier og principper.

(Det etiske råd, 1996, s. 121)

Henrik Hvenegaard Mikkelsen, dansk antropolog, beskriver i en artikel om ensomhed blandt ældre danskere

at danskere, som ofte ynder at se sig selv som et stærkt individualiseret folkefærd, mangler sproglige værktøjer til at begrebsliggøre »alenehed « som andet end en negativ tilstand. (Mikkelsen, 2019, s. 17)

Vi har ikke som på engelsk et positivt ord, som "solitude«, for at være alene. Det er ikke tilfældigt, mener Mikkelsen. Det er, fordi man i Skandinavien historisk set har inkorporeret i sin selvforståelse som folk og kultur, at vi primært er en del af et fællesskab. Han fortsætter:

Hvor det at være alene ofte betragtes som noget uønsket i Danmark, så kan man til gengæld finde en stærk, egalitær etos og en værdsættelse af fællesskab og samfund ... at den såkaldte skandinaviske egalitarisme bygger på en konstant vekslen mellem integration (fællesskab) og disintegration (individualisering). (Mikkelsen, 2019, s. 17)

I hans kontekst bruger han indsigten til at beskrive, hvordan vi i Danmark ser alenehed blandt ældre borgere beskrevet som en så negativ form for ensomhed, at der ikke gives plads til at unddrage sig fællesskabet, uden at man bliver betegnet som en »særling«.

\section{Gensidig ansvarlighed som selvbestemmelsens forudsætning}

Det er på ingen måde en ny tendens at se den enkelte som en del af fællesskabet i skandinavisk perspektiv. Det er muligvis et af de mest karakteristiske træk ved den skandinaviske egalitarisme. Ligegyldigt hvor jeg kigger tilbage i det nordiske og skandinaviske DNA, så er det just dét, jeg finder, er karakteristisk. Det gælder for så vidt også mange andre kulturer, at fællesskabet har stor betydning, man kan blot tænke på familiens betydning i middelhavskulturerne og Mellemøsten, men her har individet traditionelt set betydet mindre end fællesskabet. Det gælder ikke i de nordiske lande, så vidt jeg kan se. 
Det er for mig at se ikke underligt, at det netop er en moderne dansk og skandinavisk filosof og teolog, der skriver om karakteren af det gensidige ansvar. Det er med rette et centralt citat, som ofte anvendes i omsorgssammenhænge og i sundhedsvæsenet:

Den enkelte har aldrig med et andet menneske at gøre, uden at han holder noget af dets liv i sin egen hånd. Det kan være meget lidt, en forbigående stemning, en oplagthed, man får til at visne, eller som man vækker, en lede, man uddyber eller hæver. Men det kan også være forfærdende meget, så det simpelthen står til den enkelte, om den andens liv lykkes eller ej. (Løgstrup, 1956, s. 25)

Dette citat handler egentlig om gensidig ansvarlighed, skyldighed og forpligtethed over for det andet menneske. Det er denne forpligtethed, som udgør bagtæppet, som selvbestemmelsen kan udfolde sig på. Ansvar og selvbestemmelse er i en nordisk sammenhæng ikke modsætninger. Tværtimod er de forenende modsætninger, der styrker og skærper hinanden gensidigt. Det er ikke en svaghed at dæmpe sin ret til selvbestemmelse til fordel for hensynet til andre mennesker eller helheden, samfundet. Det er udtryk for en styrke i et skandinavisk perspektiv.

\section{Myten om Balders død}

I nordisk mytologi er den enkeltes liv båret af fællesskabet, og den enkelte kan ikke ses uden i sin sammenhæng med helheden. Den enkelte er en gren på et større træ. Skæres en gren fra, er det en sorg.

Fortællingen om Balders død er et eksempel på dødens irreversibilitet og fællesskabets rolle i forhold til døden. Døden kan man ikke handle med. I modsætning til den græsk-romerske myte om Orfeus og Eurydike så er det ikke intensiteten i en enkelt persons sorg, der her er i fokus, men derimod fællesskabets sorg over at miste et af dets medlemmer. Men selvom alt står sammen om sorgen, alt levende og dødt, så kan end ikke en fælles bestræbelse vende dødens vilje: »der vil altid være en mistelten «, som ikke er taget i ed. Døden fokuserer på undtagelsen, dén, der skiller sig ud af fællesskabet bristen i fællesskabet - misteltenen og Loke. Hvad går myten ud på?

Balder vidste, at hans egen skæbne ville blive grum, det havde han set for sig i en drøm. Frigg, Balders mor, fik derfor alle væsener og alle ting 
til at sværge, at de aldrig ville skade ham. Balder blev derved usårlig, og aserne prøvede, som morskab, at såre ham ved at kaste pile og spyd imod ham. Pile og spyd brød ikke deres ed og undveg ham altid.

Dog opdagede Loke, at Balders mor ikke havde taget misteltenen i ed. Loke lavede en pil af mistelten og fik Balders blinde bror Høder til at skyde efter Balder med pilen. Pilen af mistelten ramte Balder og han døde.

Balders mor beder Hel, dødsriget, om Balders frigivelse. Hel afviser ikke moderens ønske, men stiller en betingelse. Alt i verden, både levende og dødt, skulle græde for Balder; så kunne han få lov til at vende hjem til de levende, men hvis blot én eneste sagde nej, så skulle han blive hos hende.

Mennesker og dyr græd, og alle levende skabninger græd og alt dødt, træ og jord, malm og sten. Himlen græd, som det stadig ses, når det regner. På sommermorgener, når duggen falder på blomster, græs og strå, kan man se Balders-gråden (Møller, 1947). Kun én nægtede som bekendt at græde, nemlig den gamle kælling Tøk. Hun (som var den forklædte Loke) sagde: »Tøk skal græde tørre tåre over Balders død! Lad Hel beholde, hvad hun har!«.

Ganske vist er fællesskabet en bærende kraft, men der er brister i fællesskabet, som gør, at mennesket ikke kan sikre fællesskabet mod dødens hærgen. Misteltenen, der ikke kan tages i ed, findes, og Tøk findes, bristen i fællesskabet, som gør, at døden får det sidste ord i den nordiske mytologi. Døden kan du ikke tvinge, og bristen ligger hos mennesket. Perfekt er fællesskabet ikke, om end det har stor bærekraft (Møller, 1947).

\section{Balders død og Esthers død}

Både Balder og Esther ser for sig en grum fremtid. De er begge truet. Balder af en drøm, der forudser, at hans skæbne bliver grum, Esther af bevidstheden om, at hun vil blive yderligere svækket af sin sygdom, selvom den på det tidspunkt, filmen beskriver, ikke er langt fremskreden.

For mig at se er bristen i fællesskabet en brist, vi må acceptere med sorg. Loke, hvis han forstås som vores uendelige mulighed for at svigte fællesskabet, både som svigtet viser sig i myten og i dag. Men det er og bliver et svigt af fællesskabet - med uendelig stor betydning.

Hvor Esther, da hun ser i øjnene, at hendes fremtid bliver grum, afsondrer sig fra fællesskabet og følger sin ret til at bestemme over sit 
eget liv, så viser den nordiske myte en helt modsat vej. Da Balder ser sin grumme fremtid i møde, så slutter alle i fællesskab op om Balder og forsøger at opretholde det fælles ansvar for det enkelte medlem af slægten. Fællesskabet er endda så stærkt, at det mener, at det har sejret over den grumme fremtid, men myten viser, at om end fællesskabet står sammen, så kan fællesskabet ikke vinde over døden. Kampen mod døden i Balders tilfælde er ikke en fysisk kamp mod en dødelig sygdom, det er mere en kamp mod håbløshed og resignation overfor døden. Og for at være i stand til at kæmpe og vinde denne kamp, er vi nødt til at holde sammen. Hvis de, der står rundt om, er adskilt fra den døende, så vil den døende være alene, og så har mennesket intet at kæmpe med. Myten ser det som en styrke og ikke som en svaghed at være afhængig af fællesskabet. Balders grumme fremtidsudsigter er ikke individets problem, men er fællesskabets byrde. Fællesskabet skal bære byrden sammen. De kunne ikke drømme om at efterlade det enkelte individ i selvbestemmelsens øde landskab. I nordisk mytologi bliver den enkeltes byrde alles byrde, som de kreativt formår at konvertere til en leg, som ganske vist er overmodig, for den skaber en plads for, at misteltenens lille pil kan skade et individ. Men selv i sorgens lidelse er ingen alene og sig selv, men fællesskabet bærer sorgen sammen, og som folkesproget siger »delt sorg er halv sorg«.

»Grundmyten« i Stille hjerte er præget af en anderledes tænkning om individ og fællesskab. I selvets epoke har Esther og familien lært af tidens sprog, at det er uværdigt at være en byrde for sine omgivelser, mens det er værdigt at bevare sig som intakt og rask og at kunne bidrage til sit eget livs opretholdelse og til samfundet. Bidrager du ikke, er du »til overs« og har kun skammen over at være en belastning at falde tilbage på. Det fører til ønsket om at afslutte sit liv, mens hun endnu kan bestemme selv. Den syges og døendes »sidste ønske«, i dette tilfælde at afslutte sit liv, er den eneste stemme, der får taleret, mens fællesskabets stemme repræsenteret ved døtrenes oprør mod Esthers beslutning ingen plads får.

\section{Afslutning}

Esthers tænkning er forståelig og helt i tidens ånd, og det er egentlig det, der for mig at se er så ærgerligt. At vi i løbet af denne epoke har fået 
introduceret et menneskesyn og en selvbestemmelseskultur, som mere trækker på en moderne tænkning end på en nordisk, skandinavisk egalitarisme. Så fjernt er et fællesskabsbaseret begreb om autonomi blevet, at vi slet ikke stiller spørgsmål ved den måde, filmen ender på. De følelsesmæssige spændinger er ellers til stede. Især Heidis og Sannes forbundethed til deres mor slår ud i vældige, tsunamiagtige følelsesudsving. Kærligheden, så stort et udtryk det end kan være i denne sammenhæng, har en kraft hos de to døtre, så de er ved at sprænges.

Som i den medicinske etiks grundspørgsmål er det mit anliggende at stille spørgsmålet om at finde den vanskelige midte mellem for lidt og for meget. I den sammenhæng har det været mit ønske at rehabilitere en højere grad af fællesskabstænkning i vores begreb om selvbestemmelse. Samtidig har jeg forsøgt at belyse problematiske sider af det begreb om autonomi, som jeg mener med den moderne tænkning har vundet indpas i vores kultur.

Autonomi er noget, vi giver hinanden i fællesskabet.

\section{Referencer}

Det Etiske Råd. (1996). Dødshjoelp? En redegørelse. Hentet fra http://www.etiskraad. $\mathrm{dk} /$ /media/Etisk-Raad/Etiske-Temaer/Aktiv-doedshjaelp/Publikationer/199605-01-doedshjaelp-redegoerelse.pdf

Mikkelsen, H. H. (2019). Potentialets politik: Aldring og ensomhed i Danmark. Tidsskrift for Forskning i Sygdom og Samfund, 16(30). https://doi.org/10.7146/tfss. v15i30.114769

Kemp, P. (1991). Det uerstattelige. En teknologi-etik. København: Forlaget Spektrum.

Leget, C. (2007). Art of living, art of dying. Spiritual care for a good death. Jessica Kingsley Publishers.

Løgstrup, K. E. (1956). Den etiske fordring. København: Gyldendal.

Mogensen, J. R. (2019). Sorg er noget vi giver hinanden. I M. H. Jacobsen, M-B.

Guldin \& C. J. Busch (Red.), Giv sorgen ord. Sorgkultur i Danmark (s. 95-111).

København: Munksgaard.

Møller, Aa. (1947). Nordiske myter. Odense: Andelsbogtrykkeriet.

Oregon Health Authority. (2011). The CD summary, 6o(6). Hentet fra https:// www.oregon.gov/oha/PH/DiseasesConditions/CommunicableDisease/ CDSummaryNewsletter/Documents/2011/ohd6006.pdf

Oregon Health Authority. (2019). Oregon Death with Dignity Act. 2018 data summary. Hentet fra https://www.oregon.gov/oha/PH/ 


\section{PROVIDERPARTNERRESOURCES/EVALUATIONRESEARCH/}

DEATHWITHDIGNITYACT/Documents/year21.pdf

Schelde, J. W. (2016). Viden er vigtig, når personer med ALS også får demens.

Muskelsvindfonden.dk. Hentet fra https://muskelsvindfonden.dk/viden/viden-ogrummelighed-er-vigtig-naar-personer-med-als-ogsaa-faar-demens/

Van der Maas, P. J., van Delden, J. J. M., Lijnenborg, L. \& Looman, C. W. N. (1991).

Euthanasia and other medical decisions concerning the end of life. Lancet, 338, 669-674.

\section{Ordforklaringer}

anfægte: ifrågasätta (S), stille spørsmål ved (N)

bagtæppe: Bakgrund (S)

bestræbe: bemöda (S)

blindgyde: återvändsgränd (S), blindgate (N)

den andens: den annans (S)

efterladtes: efterlevandes (S)

enkeltes: enskilda (S)

evner: förmåga (S)

faldende evne: minskande förmåga $(\mathrm{S})$

fejhed: feghet (S), feighet $(\mathrm{N})$

fjern: avlägset (S)

folkefærd: folk (S), folkeslag (N)

forlader: lämnar (S)

forpurre: frustrera (S)

forsæt: avsikt (S)

fremsætte: lämna in (S)

fulde fem: mentalt frisk (S)

føle: känna (S)

følelsesmæssige: emotionella (S)

fælles bestræbelse: gemensam strävan (S)

gensidig: ömsesidig (S)

grum: bister (S)

græde: gråta $(S)$

handle med: förhandla med (S), forhandle med (N)

hærgen: härjning $(\mathrm{S})$, herjing $(\mathrm{N})$

kigger: kikar (S), kikker (N)

kælling: käring $(\mathrm{S})$, kjerring $(\mathrm{N})$

ligegyldig: likgiltig (S) 
lighedshensyn: jämställdhetsöverväganden (S)

mangler: saknas (S)

mitt anliggende: mitt syfte (S)

morskab: nöje (S)

nogle adgangsbetingelser: vissa åtkomstvillkor (S)

omdrejningspunktet: stödjepunkt (S)

overfor fællesskabet: gentemot samhället (S)

overskue: ha översikt (S)

selvom: även om (S)

simpelthen: helt enkelt (S)

slem: illa/ille $(\mathrm{S} / \mathrm{N})$

stemning: humör (S)

svækket: försvagats (S)

taget $\mathrm{i}$ ed: svors in (S)

tilsvarende: liknande $(\mathrm{S})$

tillige: också (S), også (N)

udfolde: fälla ut (S)

vundet inpas i: blivit en del av (S)

ærgerligt: beklagligt (S) 



\title{
KAPITTEL 7
}

\section{De to veiene til dødshjelp}

\section{Daniel Joachim H. Kleiven}

\section{Siviløkonom, masterstudent i filosofi og samfunnsdebattant}

\begin{abstract}
This chapter's claim is that arguments for legalising assisted dying essentially follow one of two paths. We can either justify it in the person's self-determination (the "autonomy path"), or in the person having rational, good reasons for his death wish (the "rationality path"). Both these lines of argument have radical consequences when their logical implications are fully pursued, and an attempt to balance these principles will be under constant pressure. This presents a challenge to those who think it is fairly straightforward to design our preferred assisted dying law, and should make us think through carefully what any legalisation will entail and what principles underlie it. If we take the principle of self-determination seriously, it leads to a very liberal assisted dying law that few Nordic advocates of legalisation would want. On the other hand, choosing the path of rationality requires that we, as a society, define criteria for when life is "not worth living", based on characteristics that large groups of fellow human beings possess, including those who do not share a desire to die.
\end{abstract}

Keywords: assisted dying, autonomy, euthanasia, legalisation, life worth living, quality of life, rationality

Det finnes bare ett virkelig alvorlig filosofisk problem: det er selvmordet. Å avgjøre om livet er verdt eller ikke verdt å leve,

det er å svare på filosofiens fundamentale spørsmål. -Albert Camus (1994, s. 7)

Dette kapitlet utforsker de to vanligste måtene å argumentere for legalisering av dødshjelp på. Det vil bli argumentert for at hver av disse, som jeg kaller henholdsvis autonomiveien og rasjonalitetsveien, har høyst problematiske implikasjoner når de følges til sin logiske endestasjon. Dette

Sitering av denne artikkelen: Kleiven, D. J. H. (2020). De to veiene til dødshjelp. I M. A. Horn, D. J. H. Kleiven \& M. Magelssen (Red.), Dødshjelp i Norden? Etikk, klinikk og politikk (Kap. 7, s. 141-156). Oslo: Cappelen Damm Akademisk. https://doi.org/10.23865/noasp.96.ch7.

Lisens: CC BY 4.o. 
innebærer ikke at nordiske tilhengere av legalisering av dødshjelp faktisk følger den ene eller den andre veien fullt ut, men jeg vil utforske hvor premissene i debatten leder oss, om de fullt ut tas på alvor. Selv om få eller ingen i den nordiske debatten per i dag har slike ekstreme standpunkt, er det verdt å granske hvor vi vil havne dersom de logiske implikasjonene blir tydelige.

Det er derfor gode grunner til å være bekymret for at lover, til tross for velmente hensikter, vil bli utsatt for et «rasjonelt press» i retning av disse endestasjonene. Til slutt viser jeg at forslag om å «følge middelveien» mellom autonomi og rasjonalitet, noe som kan virke som et naturlig mottrekk ved å balansere de to prinsippene, også medfører store problemer. Et forsøk på en slik balansegang vil gjerne ende med ubalanse, og mest sannsynlig vil en dødshjelpspraksis som forsøker å balansere prinsippene, presses i retning rasjonalitetsveien, med de problemene den gir. Påstanden om at en lov basert på to prinsipper vil tendere til å gravitere mot en grøftekant dominert av én av dem, omtales ofte som det konseptuelle skråplansargumentet, i kontrast til det empiriske (Griffiths, Weyers \& Adams, 2008, s. 513).

\section{Dødshjelp for de få}

Tre av fire nordmenn svarer at de ønsker legeassistert selvmord legalisert i visse tilfeller når pasienten nærmer seg døden (Magelssen, Supphellen, Nortvedt \& Materstvedt, 2016). Det er lett å forstå hvorfor mange svarer slik. Kanskje forestiller vi oss en person som har levd et langt og godt liv, men som nå er kreftsyk og har maksimalt et par uker igjen å leve, med utsikter til sterke smerter den siste tiden. Hvorfor skal ikke denne personen få hjelp til å «slippe» disse siste ukene, om vedkommende selv ønsker det? Mange ville nok ønsket å ha den muligheten om de var i samme situasjon.

I en perfekt verden kunne vi kanskje ha utformet en lov som bare inkluderte slike eksempler. Men svært få vil ønske at dødshjelp skal være tillatt i mange eller alle tilfeller. I undersøkelsen synker oppslutningen raskt når kriteriene forandres, som at pasientene er kronisk syke, men ikke døende (51\%), har psykiske sykdommer (17\%), eller bare er «livstrette» (18\%). 
Til tross for at autonomi benyttes hyppig i retorikken for legalisering av dødshjelp, spiller konseptet derfor en underordnet rolle i den reelle etiske begrunnelsen. Svært få ønsker at autonomi skal være rådende, slik at enhver person skal kunne få innvilget dødshjelp uavhengig av situasjonen han eller hun befinner seg i. Andre kapitler i denne boken tar opp hvor problematisk autonomikonseptet er (se særlig kap. 5 og 6). Men et fundamentalt spørsmål vi må ta stilling til, i tillegg til selvbestemmelse, implisitt eller eksplisitt, er hva slags liv som er verdt å leve.

Den stoiske filosofen Epiktet (55-135 e.Kr.) var tydelig på at både selvmord og det å hjelpe andre til å utføre selvmord kunne være akseptable handlinger. I bok II, 15 av hans Diskurser forteller han om en venn som har bestemt seg for å sulte seg i hjel, en vanlig form for selvmord på denne tiden. På tredje dag av sultestreiken reiste Epiktet til ham og spurte:

But still tell me what it was which induced you to resolve; for if you have resolved rightly, we shall sit with you and assist you to depart; but if you have made an unreasonable resolution, change your mind. (1904, s. 141)

Det er tydelig at Epiktet ikke er villig til å hjelpe til under hvilke som helst omstendigheter. Om beslutningen er feil, vil Epiktet til og med kreve at han forandrer den. Epiktet godtar ikke beslutningen bare på grunnlag av valget, men han krever at avgjørelsen må være rettferdiggjort. Men hva kan en «rettferdiggjort avgjørelse om å ta livet sitt» være? Et mulig svar finner vi hos den antikke historikerens Diogenes Laertios' beskrivelse av stoikernes syn:

They tell us that the wise man will for reasonable cause make his own exit from life, on his country's behalf or for the sake of his friends, or if he suffer intolerable pain, mutilation, or incurable disease (1925, s. 235)

\section{Jakten på en rettferdiggjort dødsbeslutning}

Tross den brede støtten til legalisering av dødshjelp som fremkommer i befolkningsundersøkelser, vegrer politikerne seg for å bringe spørsmålet på dagsordenen. Helsepersonell er dessuten langt mer negative til legalisering enn den øvrige befolkningen (Gaasø, Rø, Bringedal \& Magelssen, 
2019; se også kap. 3). En viktig grunn til dette kan være at politikere og helsepersonell i langt større grad må håndtere de praktiske realitetene og ta mange hensyn i betraktning. Da viser det seg straks utfordrende å utforme en trygg, stabil og rettferdig dødshjelpslov, hvor vi kan være trygge på at loven bare benyttes til det formålet vi ønsker (se kap. 15). Men hva om det finnes en dypere grunn til at dette er utfordrende?

Enhver lov hviler på et sett med dypere prinsipper. Disse prinsippene er etiske av natur. De forteller noe om hva vi betrakter som et gode. Vi tenker at loven som et minimum burde åpne for at frie borgere kan tilstrebe å oppnå det som åpenbart er goder, om det ikke finnes gode grunner mot det.

Vi tenker eksempelvis at ytringsfrihet fremmer viktige goder. Derfor burde staten respektere den og forsøke å fjerne begrensninger for at ytringsfrihet realiseres, om det ikke er gode grunner for noe annet, som når samme ytringsfrihet benyttes til å oppfordre til vold. Det er et gode at mennesker kan få utdanning og arbeid, så derfor kan staten forsvare å bruke ressurser for å realisere at alle dens borgere kan få det.

Likedan kan vi lage et argument hvor vi forsøker å ta autonomiprinsippet på alvor i dødshjelpsspørsmålet:

Det er et gode å fremme menneskers autonomi. Å legalisere dødshjelp tillater oss å fremme menneskers autonomi. Derfor burde vi legalisere dødshjelp.

Dersom vi tenker at autonomi er et ubetinget gode, og om det å hjelpe noen til å ta livet sitt kan fremme dette godet, skal det tungtveiende grunner til for ikke å tillate det. Men vi kan tenke at et argument hvor godet bare er definert i henhold til autonomi, mangler noe vesentlig. Det ikke vil gi noen grenser for hvem som motta dødshjelp, og under hvilke omstendigheter dette kan skje. Derfor kan vi forsøke å innføre noen kvalifikasjoner. Vi kan hevde at for en person som søker hjelp til å dø, er døden bare et gode når visse kriterier er oppfylt. Med andre ord, hvis personens død virkelig er et gode, må det være fordi det eksisterer noe slikt som et «liv ikke verdt å leve». Det kan gi oss et slikt argument:

Det er et gode at mennesker hvis liv ikke er verdt å leve, kan få hjelp til å avslutte det. Å legalisere dødshjelp gir mennesker hvis liv ikke er verdt å leve, mulighet for hjelp til å avslutte det. Derfor burde vi legalisere dødshjelp for mennesker hvis liv ikke er verdt å leve. 
Men hva kan det bety at et liv kan være «ikke verdt å leve»? Finnes det objektivt tilgjengelige kriterier vi kan sette opp for å avgjøre dette? Hvilke kriterier kan dette i så fall være?

Argumentasjonen for dødshjelp må tydeliggjøre de nødvendige betingelsene for at et ønske om å bli tatt livet av, bør etterkommes, og hvor vi til og med bør tilby vår hjelp. Her har vi grovt sett to alternativ: Enten finner vi de avgjørende betingelsene i (1) menneskets eget valg, eller i (2) noe annet enn menneskets eget valg. Som vi snart skal se, svarer autonomiveien til førstnevnte, og rasjonalitetsveien til sistnevnte. La oss starte med å se på autonomiveien.

\section{Den selvvalgte døden}

Det er unødvendig å overbevise moderne vestlige mennesker om at selvbestemmelse er et gode for en voksen person. Det har blitt et sentralt premiss i vår kultur. Men hvordan forstår vi, med våre nedarvede forestillinger, ord som autonomi og selvbestemmelse? Og hvor selvfølgelig er vår kulturelt betingede forståelse av dem?

$\mathrm{Vi}$ anser det som et gode at vi i stor grad selv kan ta avgjørelser om ting som er viktige for oss. Moderne politisk liberalisme er fundert på ideen om at rasjonelle mennesker kan ha velbegrunnede, rivaliserende oppfatninger om hva som er et gode, og at de derfor i størst mulig grad burde overlates til å ta slike beslutninger på egen hånd. Staten og andre institusjoner skal ikke være overformyndere. Vi ønsker altså å være autonome til å forme vår egen vei i livet, i samsvar med våre egne oppfatninger om det gode liv.

Men hva vil det si at et menneske utøver autonomi? Vårt moderne konsept om autonomi stammer fra den tyske 1700-tallsfilosofen Immanuel Kant, som kalte autonomi for «det suverene prinsippet for moral» (Copleston, 1994, s. 329-330). Men måten vi benytter begrepet på i dag, er langt fra Kants opprinnelige filosofi. I tiden som har gått mellom Kant og oss, er det blitt sterkt preget av et par hundre år med konkurrerende filosofiske retninger. Kants opprinnelige prosjekt var å forsøke å reetablere en universell standard for hva et gode er, og for hva som utgjør gode handlinger for mennesket. Den dominerende aristoteliske etikken hadde 
hatt denne funksjonen, men var på Kants tid gått av moten blant store deler av den vestlige intelligentsiaen.

Kant foreslo at om vi skal være moralsk ansvarlige, må vi være moralsk autonome. Våre handlinger kan ikke vurderes etisk, dersom vi bare lever opp til andre menneskers formeninger. Derfor må vi være selvlovgivere (Kant, 1993; Copleston, 1994). Men på samme tid er det ikke vilkårlig hvilke lover vi holder oss selv ansvarlige overfor. Viljen vår, som praktisk fornuft, kan aldri betraktes som uavhengig fra vår evne til rasjonalitet (Kant, 1993, s. 23). Ikke ethvert valg kan bli godt, bare fordi vi ønsker det. Men siden vi er rasjonelle vesener, må valgene våre sees i lys av en rasjonelt tilgjengelig morallov.

Hva som følger av denne moralloven, er dypest sett universelt tilgjengelig kunnskap, hevdet Kant. Men denne må vi identifisere selv, og i den forstand er vi derfor autonome. Det er noe alle mennesker til alle tider kunne komme frem til, om de stilte seg de riktige spørsmålene. Dette ledet Kant frem til innflytelsesrike ideer, slik som de kategoriske imperativene, ubetinget gyldige lover for alle fornuftsvesener (Copleston, 1994).

Kant mente dessuten at selvmord - og derfor også dødshjelp - aldri kunne forsvares, siden det var irrasjonelt å ønske sin egen ikke-eksistens. Det brøt med de kategoriske imperativene, siden eksistens er den absolutte forutsetningen for ethvert oppnåelig gode for en person (Kenny, 2006).

Et århundre senere dukket landsmannen Friedrich Nietzsche opp. Han stilte et naturlig spørsmål i møte med Kants påstand: «Hvorfor tro på en slik morallov?» Nietzsche hevdet at virkeligheten ikke kommer med slike fiks ferdige morallover. Vi må kaste av oss begrensningene av å være lenket til de tradisjonelle moralsystemene, som utelukkende var menneskeskapte, utviklet i troen på at det eksisterte noe slikt som en morallov, med gitte standarder for hva som var godt og ondt, bedre og verre. Bare da kan vi bli frie, mente Nietzsche, når vi kan skape oss selv, omfavne livskraften og det virkelige menneskelige. Vi må snarere forsøke å leve i en slags kunstnerisk utfoldelse av det fulle spekteret av våre evner.

Til forskjell fra Kant betraktet Nietzsche viljen vår løsrevet fra påstanden om at vi er fornuftsvesener som vurderer i henhold til gitte etiske kategorier. Det er verdt å merke seg at Nietzsche beskriver selvmordet i langt mer positive ordelag enn Kant: 
Den syke er en parasitt på samfunnet. I en viss forstand er det uanstendig å leve videre. (...) Å dø på en stolt måte, når det ikke lenger er mulig å leve på en stolt måte. Døden, valgt av egen fri vilje, døden til rett tid, med klarhet og glede, fullendt blant barn og avkom: slik at en virkelig avskjed fortsatt er mulig, hvor den som tar avskjed, fortsatt er der, likeledes en virkelig vurdering av det oppnådde og villede, en oppsummering av livet. (2008, s. 81)

En siste tenker som er verdt å trekke frem, nærmere vår egen tid, er den franske eksistensialisten Jean-Paul Sartre. Vi kan velge fritt, mente han, men bare på grunn av at eksistens er forut for essens. Mens Aristoteles hadde hevdet at mennesket har en gitt natur (essens), som er bestemmende for hva som vil være rasjonelle og gode valg for et individ av vår art, påsto Sartre at dette ikke kunne være sant. For at mennesket skal kunne være fritt, må vi først og fremst være skapere av vår egen essens. Vi bestemmer selv, også hva vi skal være, kontinuerlig (Sartre, 1946). Sartre har altså radikalt forlatt Kants opprinnelige forståelse av autonomi, både som det å velge som et individ som innehar en natur som fornuftsvesen, og at vi handler i tråd med en rasjonell morallov. Personen som velger, vil, ifølge Sartre, gjennom valget skape seg selv, og derved også fasiten på hva som er et godt valg for vedkommende.

Når vi i dødshjelpsdebatten foreslår at autonomi skal være et rådende prinsipp, avhenger betydningen av dette altså fullstendig av hvilket autonomikonsept vi har i tankene. Om vi tenker på Kants autonomi, må det autonome valget alltid sammenholdes med en rasjonell standard (moralloven). Den avgjørende autoriteten for valget ligger et annet sted enn i menneskeviljen selv. Men det vi ofte har i tankene når vi snakker om «autonomi» i vår kultur, er i større grad formet av arven fra Nietzsche og Sartre, hvor autoriteten ligger hos oss alene. For et slikt autonomibegrep er det sentrale at det er $v i$ som velger - ikke $h v a$ vi velger. Men hva blir konsekvensen dersom vi utformer en dødshjelpslov ut fra det prinsippet?

Om denne versjonen av autonomiveien følges, får valget altså all nødvendig autoritet fra det enkle kriteriet av at det tilhører subjektet selv. Vi andre kan ikke bedømme valget ut fra kriterier om hvorvidt valget er godt, bedre, rasjonelt eller noe lignende, selv om valget er å ta ens eget liv.

For en dødshjelpslov som tar et slikt autonomiprinsipp fullt ut på alvor, blir mange foreslåtte betingelser, slik som at personen må være terminalt 
syk eller oppleve uutholdelig lidelse, straks uholdbare begrensninger for utøvelsen av autonomi. Vi som medmennesker kan ikke uten videre tvinges til å hjelpe vedkommende med å utføre dette, men det er heller lite som hindrer oss i å hjelpe til. Dersom det å hjelpe personen til å ta sitt eget liv samsvarer med hva vi ønsker å gjøre, utøver vi likedan bare vår autonomi. Loven burde ikke ha noen autoritet til å gripe inn for å hindre eller begrense dette.

Nordiske dødshjelpstilhengere flest vil forståelig nok finne en slik lov lite attraktiv, men da bør de samtidig innrømme at de lar andre hensyn overstyre prinsippet om respekt for personens selvbestemmelse. Da er det et annet prinsipp som dypest sett begrunner, og setter grenser for, tilbudet om dødshjelp.

I dødshjelpslandet Nederland har holdningene beveget seg langt $\mathrm{i}$ denne retningen. I en undersøkelse av holdningene til den generelle befolkningen, publisert i 2012, sa hele $57 \%$ seg enig $i$ at «alle burde ha en rett til å få dødshjelp når han eller hun ønsker det», mens bare $23 \%$ var uenige (van der Heide et al., 2012a; se også kap. 12 og 13).

\section{Kan mennesket miste sin verdi?}

Om autonomi ikke skal være tilstrekkelig for å motta dødshjelp, må det altså noe mer til. Dersom det finnes en gruppe A for «personer som bør få avslag på en forespørsel om dødshjelp», og en gruppe B for «personer som bør få innvilget en forespørsel om dødshjelp», må vi finne ut hva som er de nødvendige betingelsene som skiller en person i gruppe A fra en person i gruppe $\mathrm{B}$.

Om noe annet enn menneskets egen vilje er nødvendig, må vi begynne med å oppgi hvilke grunner som kan være tilstrekkelige for at et menneske skal kunne be om hjelp til å dø, og få innvilget dette. Hvis vi gjør som Epiktet og krever at en slik avgjørelse skal være «rettferdiggjort», hva er det da som kan rettferdiggjøre det? Hva er de definerte kriteriene, hvor vi kan svare en person «Ja, i ditt tilfelle er død et gode», eller «Under dine omstendigheter, vil en forespørsel om dødshjelp være rettferdiggjort»?

Dette kan knyttes til velgjørenhetsprinsippet, et av de fire grunnleggende medisinsk-etiske prinsippene. Vi må identifisere hva det er som 
kjennetegner medlemmene i gruppen som får innvilget dødshjelp, som gjør at det kan være rettferdiggjort å ta livet av dem, fordi livet deres ikke er verdt å leve. Å ta livet deres, eller å hjelpe dem til å ta sitt eget liv, kan da hevdes å være velgjørende. Vi utfordres her til å sette opp en standard for hva som er (1) liv verdt å leve, og (2) liv ikke verdt å leve.

Hvordan ville disse kriteriene se ut? Sannsynligvis ville de pekt ut egenskaper som kjennetegner mennesket på sitt mest sårbare. Vanlige forslag er kort forventet levetid, stor grad av opplevd fysisk og/eller psykisk lidelse, nedsatt funksjonsevne, tap av kognitive evner og avhengighet av andre. Flere av disse er blant de hyppigst oppgitte grunnene fra folk som velger dødshjelp i Oregon (Oregon Public Health Division, 2019).

Merk at slike kriterier gir egenskaper som formuleres helt uten hensyn til menneskets faktiske autonomi, og hvorvidt de selv samtykker til å tilhøre denne gruppen eller ikke. Om vi sier at et sett med definerte egenskaper kjennetegner en person hvor død er et gode, som kjennetegner en person som tilhører gruppen for hvem det kan vere rasjonelt å be om sin egen død, sier vi det både på vegne av de som ønsker dødshjelp, og de som ikke gjør det. Vi forteller borgere i denne gruppen at deres liv ikke er verdt å leve, og at deres død er et gode. Med andre ord, hvis det eksempelvis er et gode å dø for en samtykkekompetent person som $ø$ nsker sin egen død, på grunn av at vedkommendes tilværelse har visse egenskaper, er ikke døden på samme måte et gode for alle andre med tilsvarende egenskaper, uavhengig av om de er kompetente eller om de $ø$ nsker sin egen død?

Det er nærliggende å tenke at kriteriene vi setter opp, også vil være oppfylt for et stort antall mennesker som er fornøyd med å leve, og som ikke ville ha uttrykt noe ønske om å dø. Internasjonalt er eksempelvis flere interesseorganisasjoner for funksjonshemmede og psykisk utviklingshemmede aktive motstandere av legalisering av dødshjelp. Det gir mening - i lys av at en slik liste med kriterier vil komme til å inkludere mange av deres medlemmer, som kan komme til å oppleve seg stigmatisert.

Vi er ansvarlige for våre egne valg, men menneskers avgjørelser påvirkes gjerne av individuelle og sosiale vilkår (se også kap. 5 og 6). Individuelle vilkår inkluderer slikt som alder, temperament og smak, naturlige 
ferdigheter, og så videre. Gitt våre forskjeller, er det naturlig for oss å velge ulikt under ellers like omstendigheter. Sosiale påvirkninger inkluderer vår nærmeste familie, våre venner og storsamfunnet. Hvilke muligheter vi som samfunn gjør tilgjengelige, som institusjonaliseres av myndighetene, og hvilke verdier som råder i kulturen vår, vil forandre vilkårene for generasjonene etter oss (Oderberg, 2005).

Om vi formaliserer kriterier i lov og praksis for hva som er liv verdt å leve, og når død kan være et gode for en person, kan vi forvente at nye generasjoner vil skyve på grensene på måter som vil være overraskende for oss, når deres egne sosiale vilkår forandres. Spesielt under stramme tider - med sosial turbulens, begrensede ressurser, trusler om konflikt eller krig - kan slike prosesser tilta. Vi burde i det minste stoppe opp og granske vår tradisjonelle forståelse av mennesket som noe med iboende og ubetinget verdi, som ligger til grunn for menneskerettighetserklæringen. Er det gode grunner til at sivilisasjonen vår har holdt fast ved dette, som et viktig sikkerhetsnett for samfunnets mer sårbare medlemmer? Observasjoner fra andre kulturer og andre epoker lærer oss at det er lite ved menneskenaturen per se som hindrer oss i å utsette sårbare grupper for et farlig press, om våre oppvekstvilkår og vår sosiale påvirkning skulle gjennomgå en drastisk forandring.

Det finnes allerede anerkjente tenkere som har forsvart at vi burde tilbake til Epiktet, Nietzsche eller en romersk tankegang hvor det å «falle på sverdet sitt», å velge døden av hensyn til andres interesser, er det mest ærbare. Tenkere som Mary Warnock har forsvart en «plikt til å dø» (2008).

\section{Hvorfor skal dødshjelp være frivillig?}

For å sikre at dødshjelpskandidaten virkelig er misfornøyd med livet og ønsker å dø, vil vi kvalifisere at dødshjelp skal være på frivillig og kompetent forespørsel, som er to vilkår som inngår i selve definisjonen av dødshjelp i kap. 2. Forkjempere for legalisering tar det gjerne som en selvfølge at det er dette man ønsker å innføre. Dette er den formen for legalisering av dødshjelp som er enklest å forsvare i en kultur som vår, sterkt preget av anerkjennelsen av det selvstendige individet. Om ikke frivillig dødshjelp 
kan forsvares hos oss, kan trolig ikke noen form for «dødshjelp» forsvares, slik som «medisinsk drap uten forespørsel».

Men hvor opplagt er dette? Om man eksempelvis resonnerer etter konsekvensetiske prinsipper, noe som i dag er populært blant både profesjonelle etikere og andre, er ikke subjektets «frivillige og kompetente forespørsel» per se noe som vil avgjøre hvorvidt handlingen er forsvarlig. Det som derimot gis vekt i det etiske regnskapet, er konsekvensene som finner sted etter at handlingen er utført.

Når vi skal finne frem til hva som er de gyldige målekriteriene for «gode konsekvenser», og vurdere hvordan vi kan vekte disse opp mot visse «dårlige konsekvenser», må vi i prinsippet alltid være åpne for at andre hensyn veier tyngre enn respekten for personens autonomi. Den innflytelsesrike etikeren Peter Singer uttalte som preferanseutilitarist ${ }^{1}$ eksplisitt at dette kan være tilfellet: «If we are preference utilitarians, we must allow that a desire to go on living can be outweighed by other desires» (Singer, 2011, S. 99).

Vi kan legge merke til at disse «other desires» i prinsippet ikke trenger å tilhøre personen selv. Det kan fint være at andres preferanser om at en person skal avslutte livet, kan utkonkurrere vedkommendes egen preferanse om å fortsette å leve. Det kan intuitivt høres overraskende ut, men det er langt fra utenkelig. Vi kan fint se for oss en rekke situasjoner hvor det kan være tilfellet.

En person med sterk funksjonsnedsettelse kan utgjøre en stor økonomisk belastning, og legge beslag på mye tid og ressurser fra helsepersonell, venner og familie. En hatet maktperson kan gjøre livet surt for en storfamilie eller for en gruppe mennesker som helst skulle sett vedkommende død. En mislikt minoritet kan skape ustabilitet i et samfunn, hvor mange tenker de ville hatt det bedre uten dem. De kan betrakte døden til et individ eller en gruppe av individer som et gode, om enn ikke for individet selv, så for storsamfunnet og i sum. Dette vil vektes mot de samfunnsmedlemmene som kan ha preferanser om at individet skal få leve, men det er ikke gitt hva utslaget av denne vektingen vil være. Det som er

En form for konsekvensetikk hvor godheten av handlingen analyseres ut fra hvor mange individers preferanser som blir oppfylt. Singer har siden «konvertert» til hedonistisk konsekvensetikk. 
enda mer uklart, er hvordan vi moralsk kan fordømme slike tankerekker om vi først tillater konsekvensetiske resonnementer. Autonomien har her blitt underordnet rasjonalitetshensyn og storsamfunnets tanker om hva som er et liv verdt å leve for samfunnets individer.

Om vanlig foreslåtte størrelser som «preferanse», «lykke» eller «nytte» skal kunne være en felles måleenhet, må vi kunne oversette alle hensyn til den valutaen - fra individets egne ønsker og kompetanseevne til verdighet og menneskerettigheter, til kortsiktige og langsiktige interesser til alle involverte, til dagens utvikling av medisinsk teknologi, til makro$ø$ konomiske regnestykker, osv. Men i en slik oversettelsesprosess, hvor vi foretar en kvantitativ vekting, er det vanskelig å unngå at denne vil være dels vilkårlig.

Om man ikke er konsekvensetiker, kan det likevel være at man kan holde fast ved at menneskets frivillige, kompetente forespørsel er absolutt nødvendig for at vi i det hele tatt skal kunne tenke oss at dødshjelp kan være aktuelt. Og kan man ikke gjøre det uten å havne i motsatt autonomigrøft, som beskrevet ovenfor? Det skal vi se nærmere på her.

\section{En gyllen middelvei?}

Er vi nødt til å følge et prinsipp fullt ut, slik som autonomi eller rasjonalitet, og dermed ende opp med et ekstremt standpunkt når de logiske implikasjonene følges til sin ende? Griffiths et al. (2008, s. 513) kaller dette for en feilslutning («one law, one principle-fallacy»), og hevder at man utmerket godt kan ha flere prinsipper som balanserer hverandre. Ifølge dem er dette tilfellet i Nederland og Belgia, hvor ikke bare autonomi, men også velgjørenhet, er rådende prinsipp.

Det å kombinere flere prinsipper er ikke ukjent på andre områder. Legen godtar pasientens frivillige forespørsel om morfin, men bare om han eller hun vurderer det som medisinsk indisert; med andre ord, om ønsket anses som rettferdiggjort. Om pasienten bare ønsker morfin som rusmiddel, har helsepersonell grunn til å avslå forespørselen. Både autonomi (informert samtykke) og en begrunnelse (medisinsk indikasjon) må altså være til stede. Kan vi ikke tenke tilsvarende i dødshjelpsspørsmålet? 
I én forstand kan vi selvsagt det - det er jo nettopp det vi ser forsøkt i de landene som har legalisert dødshjelp. Men problemet er at kombinasjonen er ubalansert; det er rasjonaliteten og ikke autonomien som er det førende prinsippet i argumentasjonen. For, som det er argumentert for over, blir dødshjelpen rettferdiggjort av dødsønskets begrunnelse, snarere enn at det springer ut fra personens selvbestemmelse. Hvis døden på grunn av noen definerte kriterier er et gode for personen som fremmer et autonomt ønske om å dø, er døden et like stort gode for personen som ikke fremmer noe slikt ønske, og/eller ikke har evnen til å fremme noe ønske.

Slike fakta skaper et «press» i retning av å utvide tilbudet om dødshjelp også til større grupper og ikke-samtykkekompetente pasienter. Påstanden er ikke at en slik utvidelse med nødvendighet vil finne sted, men at det blir vanskelig å finne gode, logisk konsistente argumenter imot.

Årsaken til det er at forsøket på å balansere to prinsipper vil være konstant tilbøyelig til å favorisere et av dem. Ubalansen blir også stadig mer synlig i empirien fra land som har forsøkt å legalisere dødshjelp. I Nederland har denne favoriseringen gitt seg utslag $i$ at loven tolkes mye bredere enn før, om enn ordlyden er uendret (se kap. 13). Der er det avgjørende kriteriet for å motta dødshjelp at den dødshjelpssøkende uttrykker å oppleve en uutholdelig lidelse, fysisk eller psykisk; og i de senere årene har også generell livstretthet blitt foreslått som en form for uutholdelig lidelse. Kriteriet om opplevd uutholdelig lidelse kan nettopp medvirke til å skape en god balanse, siden det gir oss både en frivillig forespørsel og en fornuftig begrunnelse. Men samtidig, ved å inkludere en begrunnelse som er helt og fullt subjektiv, er den avgjørende autoriteten på nytt hos subjektet selv. Opplevelser er per definisjon private for den som opplever.

Med slike kriterier har det oppstått en situasjon hvor mer restriktive leger kan avvise forespørselen om dødshjelp, men hvor pasienten deretter kan henvende seg til fagpersonell de vet vil tolke lovverket mer liberalt. Den nederlandske pro-dødshjelpsorganisasjonen NVVE etablerte i 2012 den såkalte «Levenseindekliniek», hvor søkere som hadde fått avslag på forespørselen om dødshjelp, kunne få en ny lege på besøk, en som var mer villig til å innvilge dødshjelp. I løpet av de årene klinikken har eksistert, har antallet årlige henvendelser økt fra 603 til 2564 (Levenseindekliniek, 2018; kap. 13). 
En pasient som ikke er samtykkekompetent, kan likedan fortelle at han også lider og ønsker å dø. Om vi i tillegg har gode grunner til å tenke at personen virkelig opplever stor lidelse, tilsier velgjørenhetsprinsippet at han burde få innvilget ønsket sitt. Vi kan dessuten vurdere at når personen ikke bare opplever lidelse, men også mangel på samtykkekompetanse, bidrar det bare til å gjøre situasjonen enda mer uutholdelig. Legen kan tenke at dersom han selv var i denne situasjonen, ville han definitivt ønsket å dø. Hvordan kan vi forsvare at mangelen på samtykkekompetanse gjør at det likevel ikke vil være et gode for pasienten å $\mathrm{d} ø$ ? Her virker det inkonsistent og brutalt å frata den ikke-samtykkekompetente pasienten tilgangen til dette godet, bare fordi han ikke kan fremme en kompetent forespørsel.

Hva om vi i fremtiden har et samfunn som i stor utstrekning har omdefinert død som et mulig gode for personer som lever under visse omstendigheter? Og at leger har en dødbringende sprøyte i verktøyskrinet sitt til disse personene, sammen med smertelindring og andre medikamenter? Hva om de tillates å benytte denne på ikke-samtykkekompetente pasienter i en miserabel situasjon, hvor legen vil tenke at hun eller han selv ville ønsket å dø? Vil ikke det være realistisk å tenke seg? Naturligvis er det en viss risiko for at legen vurderer dette feil, og at det vil bli enkelte ofre for feilaktige vurderinger underveis, men vi kan likevel tenke oss at sakens alvor gjør at vi må leve med den risikoen.

\section{Konklusjon}

På hver sin måte oppsummerer Epiktet og Sartre, med rasjonalitets- og autonomiveien, de to argumentasjonslinjene som kan gis for legalisering av dødshjelp. For Epiktet er grunnene viktigst, mens for Sartre er det avgjørende snarere at det er $v i$ som velger. Disse to prinsippene kan harmonere, men vil også ofte komme i konflikt med hverandre.

Det som står på spill i dagens debatt om dødshjelp, er sjelden hvorvidt et menneske skal ha mulighet til å utøve sin vilje. Stridsspørsmålet er snarere hvilket handlingsrom viljen skal ha, og - i forlengelsen: Hva kan være et rettferdiggjort valg for et menneske til å be om hjelp til å ta sitt eget liv? Og hva kan være et rettferdiggjort valg for at en lege skal kunne bistå med dette? 
De færreste borgerne i Norden ønsker at enhver person skal ha muligheten til å be en profesjonell om hjelp til å ta livet av seg, av en hvilken som helst grunn. Den relevante diskusjonen vi i så fall sitter igjen med, er hva som kjennetegner omstendighetene hvor vi kan si at et liv ikke er verdt å leve, situasjoner hvor vi kan kalle død for et gode for et menneske.

Men det å definere en gruppe mennesker etter et sett med egenskaper, hvor følgene er at disse egenskapene kvalifiserer dem til medlemskap i gruppen med «liv som ikke er verdt å leve», kan utfordre idealet om et inkluderende samfunn, hvor vi holder fast ved en grunntanke om at menneskers verdi ikke kan rangeres slik, og at alle mennesker har lik verdi, uavhengig av egenskaper. Dette er utfordringer som gjør at vi ikke kan debattere dødshjelp isolert fra de større spørsmålene om menneskesyn og lovverk, som er viktige for hvilket helhetlig samfunn vi sammen ønsker å skape. Nettopp derfor må vi granske prinsippene som ligger til grunn for argumentasjonen vår.

\section{Referanser}

Camus, A. (1994). Myten om Sisyfos. Essay om det absurde. Oslo: J. W. Cappelens forlag.

Copleston, F. (1994). A history of philosophy volume VI. New York: Doubleday.

Epiktet. (1904). Discourses. Oversatt av G. Long. New York: D. Appleton and Company.

Gaasø, O. M., Rø, K. I., Bringedal, B. \& Magelssen, M. (2019). Legers holdninger til aktiv dødshjelp. Tidsskrift for Den norske legeforening, 139, 31-5.

Griffiths, J., Weyers, H. \& Adams, M. (Red.) (2008). Euthanasia and law in Europe. Oxford: Hart Publishing.

Kant, I. (1993). Grounding for the metaphysics of morals. Indianapolis: Hackett.

Kenny, A. (2006). A new history of western philosophy, vol 3. New York: Oxford University Press.

Laertius, D. (1925). Lives of eminent philosophers. London: William Heinemann.

Leveseindekliniek. (2019). Jaarverslag 2018 - beleidsplan 2019. Hentet 31.08.19 fra http://slk-jaarverslag-beleidsplan.nl/2018-2019

Magelssen, M., Supphellen, M., Nortvedt, P. \& Materstvedt, L. J. (2016). Attitudes towards assisted dying are influenced by question wording and order: A survey experiment. BMC Medical Ethics, 17. 
Nietzsche, F. (2008). Avgudenes ragnarok - eller hvordan man filosoferer med hammeren. Oslo: Spartacus Forlag.

Oderberg, D. (2005). Moral theory: A non-consequentialist approach. Oxford: Blackwell Publishing.

Oregon Public Health Division. (2019). Oregon death with dignity act 2018 data summary. Hentet 15.12.19 fra https://www.oregon.gov/oha/ PH/PROVIDERPARTNERRESOURCES/EVALUATIONRESEARCH/ DEATHWITHDIGNITYACT/Documents/year21.pdf

Sartre, J.-P. (2007). Existentialism is a humanism. New Haven: Yale University Press. Singer, P. (2011). Practical ethics, $3^{\text {rd }}$ edition. Cambridge: Cambridge University Press. van der Heide, A, Kouwenhoven, P., Raijmakers, N., van Delden, J. J., Rietens, J., Schermer, M., ... van Tol, D. (2012a). Opinions of health care professionals and the public after eight years of euthanasia legislation in the Netherlands: A mixed methods approach. Palliative Medicine, 27(3), 273-80.

van der Heide, A, Omwuteaka-Philipsen, B. D., Brinkman-Stoppelenburg, A., Penning, C., de Jong-Krul, G. J. \& van Delden, J. J. (2012b). Trends in end-of-life practices before and after the enactment of the euthanasia law in the Netherlands from 1990 to 2010: A repeated cross-sectional survey. Lancet, 380(9845), 908-15. Warnock, M. (2008). A duty to die? Omsorg, 25(4), 3-5.

\section{Ordforklaringer}

fremme: främja $(S)$

gitte: given (S), givne (D)

henholdsvis: respektivt (S)

hyppig: ofta (S)

innvilget: beviljats (S), bevilget (D)

sannsynlig: sannolikt (S)

skyve på grensene: driva gränserna (S), skubbe grænserne (D)

velgjørenhetsprinsippet: välgörenhetsprincipen (S), princippet om at gøre godt (D) 


\title{
Fortellinger om død, verdsetting av liv
}

\author{
Jan Grue
}

Institutt for spesialpedagogikk, Universitetet i Oslo

\begin{abstract}
Assisted dying is, almost by definition, a dramatic topic. Thus it can also be dramatised, both in fiction and in media coverage. Stories, whether they are bestseller books like Jojo Moyes' Me Before You or newspaper articles that spread virally, can reach a large audience. Stories also serve as indirect arguments. By depicting how assisted dying might or ought to work, they also express a normative stance on reality. This chapter investigates the patterns of some culturally central narratives of assisted dying, and questions the value judgments expressed in them. It also raises the question of which premises for further debate are brought about by such stories - premises about the assessment and valuation of human life.
\end{abstract}

Keywords: assisted dying, euthanasia, life worth living, narrative, rhetoric, quality of life

\section{Innledning. Tankeeksperimenter, fortellinger og argumenter}

Dette kapittelet handler ikke om dødshjelp forstått som et medisinsk eller juridisk spørsmål, men som tema i fortellinger, da både mediefortellinger og litterære fortellinger. Jeg er verken medisiner eller jurist, derimot språk- og kulturforsker, og jeg arbeider ut fra en hypotese om at språk i sin alminnelighet, og fortellinger i særdeleshet, former vårt inntrykk av verden. Dette gjelder også verdi- og samfunnsspørsmål, der mange, kanskje særlig de av oss som ikke har førstehåndserfaringer, danner oss inntrykk og oppfatninger på bakgrunn av fortellinger. På denne måten

Sitering av denne artikkelen: Grue, J. (2020). Fortellinger om død, verdsetting av liv. I M. A. Horn, D. J. H. Kleiven \& M. Magelssen (Red.), Dødshjelp i Norden? Etikk, klinikk og politikk (Kap. 8, s. 157-171). Oslo: Cappelen Damm Akademisk. https://doi.org/10.23865/noasp.96.ch8.

Lisens: CC BY 4.0. 
fungerer fortellinger som bindeledd mellom «er» og «bør». De bidrar til samfunnets forståelse ikke bare av hva dødshjelp er, men også - og kanskje enda viktigere - av hva som utgjør et godt liv eller et liv verd å leve.

Den amerikanske forfatteren og essayisten Joan Didion har et mye sitert epigram, hentet fra boken The White Album (1979). Hun skriver: We tell ourselves stories in order to live. Det høres beroligende ut, fortrøstningsfullt. Og slik siteres gjerne disse ordene, for å formidle dette budskapet - fortellinger gir mening, de hjelper. De neste par setningene tar imidlertid en helt annen vending: We look for the sermon in the suicide, for the social or moral lesson in the murder of five. We interpret what we see, select the most workable of the multiple choices. Det vil si, vi bruker fortellinger som et verktøy for å skape mening, men ikke alltid med et solid grunnlag. Moralen er ikke i hendelsene, vi skriver den inn - som best vi kan.

Dette blir særlig viktig i fortellinger om liv og død. Av alle meningsløse hendelser er et meningsløst dødsfall det verste. Det er derfor vi som mennesker arbeider hardest for å se sammenhenger og begrunnelser for døden.

Jeg skriver altså dette kapittelet ut fra to sentrale og beslektede antakelser. Jeg tror at fremstillinger av hvordan noe er, også fiktive eller hypotetiske fremstillinger, påvirker oppfatningene våre av hvordan ting burde være. Jeg tror også at vi ofte argumenterer, resonnerer og tenker via fortellinger om enkeltmennesker, også når det gjelder såkalt prinsipielle spørsmål. Det moderne medielandskapet er i all hovedsak strukturert rundt disse antakelsene. «Sterke historier» om enkeltmennesker blir bærende i debatter, og når det å fortelle disse historiene fører til politisk endring, kan mediene være fornøyd med sin evne til gjennomslag og påvirkning.

Enkelthistorier er ofte slående. Senest i februar 2019 ble det (posthumt) trykket et innlegg forfattet av Inger Staff-Poulsen (Staff-Poulsen, 2019) med tittelen «Vedlagte kronikk er kanskje litt kontroversiell - fordi jeg er død». Det ble svært mye delt og lest, og blir trolig stående som nettopp et sterkt argument for liberalisering av dødshjelp. Med henvisning til et retorisk begrep hviler dets styrke på etos, altså forfatterens personlige troverdighet. Fordi den avdøde taler på egne vegne og bokstavelig talt har hatt livet som innsats, finnes det begrenset rom for å møte argumentene akkurat i dette tilfellet. Staff-Poulsen kan vanskelig overprøves hva gjelder hennes liv. Spørsmålet er heller hvordan hennes fortelling fungerer 
som argument i andre sammenhenger; det handler om overføringsverdi, og om overføring av verdier.

Naturligvis er ikke alle med på disse antakelsene om fortellingenes makt. Forhistorien til dette kapittelet begynte med et essay jeg skrev i Morgenbladet høsten 2016, og som ledet til en brevveksling med filosofen Ole Martin Moen (Grue \& Moen, 2016). Han er blant de tydeligste norske forkjemperne for innføring av dødshjelp (Moen \& Sterri, 2019), på prinsipielt grunnlag, og regien for brevvekslingen vår var ment å være pro et contra, en noenlunde balansert meningsutveksling om et vanskelig etisk og politisk spørsmål.

Delvis var denne brevvekslingen vellykket, i den forstand at mange sentrale argumenter i debatten som også motiverer denne boken, fikk nå frem til et bredt publikum. På mange måter var imidlertid brevvekslingen en fiasko, fordi Moen og jeg i stor grad snakket forbi hverandre. Kan hende skyldtes det våre respektive faglige bakgrunner - filosofi for hans del, diskursanalyse og retorikk for min del. Vi var, blant annet, uenige i om det er legitimt å argumentere med basis i et tankeeksperiment (hva skal man gjøre dersom et menneske både lider uutholdelig og ikke har noen utsikt til bedring?) som legges frem med minimal kontekst (stammer lidelsen fra en sykdom, eller kan den spores til hvordan samfunnet er organisert?). Den analytiske filosofien trives med isolerte, prinsipielle tankeeksperimenter som strategi for å nå frem til overordnede sannheter. Retorikken er ikke like komfortabel med denne måten å resonnere på, fordi den insisterer på at ethvert eksempel som inngår i en argumentasjon, først og fremst skal overbevise. Verken scenarier eller historier er uavhengige av virkeligheten - uansett hvor hypotetiske de er ment å være.

Jeg skal ikke forsøke å rekapitulere hele debatten her; det er litt for fristende å utkjempe gamle kamper når motstanderen ikke er til stede. Likevel tror jeg at poenget over tåler å utvikles. Tankeeksperimenter og fortellinger settes uunngåelig inn i ulike kontekster, de fortolkes og brukes til å skape mening. Dette er en grunnleggende menneskelig tilbøyelighet. Vi lytter ikke til historier fra et nøytralt ståsted. Et underliggende spørsmål om enhver historie er om den er et mulig identifikasjonspunkt, om den potensielt handler om oss selv eller noen vi kjenner.

Derfor er det viktig hvilke historier vi som samfunn forteller oss selv - om livene vi lever og hva slags mening de har. I dette kapittelet 
er det slike fortellinger som er i fokus, og da først og fremst fortellinger om hvilke liv som er verd å leve, og hvilke som ikke er det. Fortellinger har en sterk overbevisende kraft, også indirekte. Det er derfor det er viktig, kanskje særlig når det gjelder etiske og politiske dilemmaer, å se nøye på disse fortellingene og hvilke moralske implikasjoner de bibringer.

\section{Det meningsløse livet og den gode døden}

Fortellinger kommer i mange former; de kan være så korte som en setning. Et sitat fra D. H. Lawrence - den store modernisten, den store litterære vitalisten - har hjemsøkt meg siden jeg først leste det i John Careys The Intellectuals and the Masses (2012). Det er en fortelling i form av et bilde, og det er i høyeste grad et bilde av sin tid, det tidlige 190o-tallet. Blant Careys temaer er spenningen som på den tiden hersket mellom progressive, utopiske prosjekter og den sendrektige, gjenstridige virkeligheten. Modernismen sammenfalt med rask urbanisering og det brede demokratiets gjennombrudd. Det var smertefullt for mange intellektuelle, som Lawrence, å måtte forholde seg til et folkedyp som ikke bare var mer vrimlende og fysisk tilstedeværende enn tidligere, men som hadde tilkjempet seg en helt annen grad av politisk makt. Han anså den nye menneskemassen som truende, også fordi den så tydelig besto av fattige mennesker, av de laveste i samfunnet. De var sykere enn overklassen, de var svakere, de var på alle måter av lavere kvalitet. Men det var mange av dem, og disse menneskenes eksistens ble forstått som et problem. I et privat brev skisserte Lawrence sin løsning:

If I had my way, I would build a lethal chamber as big as the Crystal Palace, with a military band playing softly, and a Cinematograph working brightly; then I'd go out in the back streets and main streets and bring them in, all the sick, the halt, and the maimed; I would lead them gently, and they would smile me a weary thanks; and the band would softly bubble out the 'Hallelujah Chorus'. (Boulton, 1979, p. 81)

Ordene ble skrevet i 1908, fremtidsoptimismens tid, før første verdenskrig, før de faktiske dødskamrene, som jo minnet relativt lite om det 
skinnende Crystal Palace. To detaljer er uventet viktige her. Lawrence inkluderer en kinematograf, det nyeste nye innen teknologi, og han ser for seg en empatisk relasjon, en gjensidig - om enn underforstått - enighet om at døden er et gode for dem som ledes nennsomt inn i kamrene. Dette er til det beste for alle. Det finnes en form for renselse her.

Denne minifortellingen er rik. Dette kan vi forvente av en av sitt århundres viktigste forfattere. Visjonen Lawrence beskriver, er poetisk komprimert og destillert. Den er også paradoksal. Det historiske Crystal Palace var et byggeteknisk mesterverk, et symbol på teknologi- og sivilisasjonsoptimisme, og en skjærende kontrast til dødskamrene Lawrence så for seg. Men dette paradokset er ikke særegent for ham, det kommer av idéhistoriske strømninger som preget hele hans tid. Det umiddelbare bakteppet er eugenikken, som for alvor var i ferd med å slå gjennom som politisk bevegelse. På de eugeniske verdenskongressene deltok forskere, kunstnere - og politikere. De delte en drøm om et bedre, lykkeligere og fremfor alt renere samfunn, et som var renset for dårlig genmateriale og unødvendig menneskelig lidelse.

Ingen skisserer en politisk løsning med mindre de ser et politisk problem. Mot slutten av 1800-tallet begynte det for alvor å bli klart at industrialiseringen og urbaniseringen var en akselererende og til dels ukontrollert prosess. Menneskene levde tettere på hverandre enn noensinne, i menneskeskapte omgivelser. Bekymringen var at noe autentisk hadde gått tapt - det virkelige livet, betingelsene for det gode livet. I romanene sine idealiserte Lawrence et liv tettere på naturen, en tilbakeskuende vitalisme. Når dette livet ikke lenger er mulig, når industrialiseringen har skapt en uholdbar situasjon i form av massenes uverdige liv, er det også teknologien som må tilby løsningen. Det dødsforherligende sitatet ser fremover, mot det som skal og må komme.

Verdisynet til Lawrence er også verd en tanke. Han skriver om menneskelivene som ikke er verd å leve - som han ikke kan forestille seg er verd å leve. The sick, the halt, and the maimed, de som vil takke ham pent for å kunne legge fra seg denne forferdelige byrden. Det er de fattige og syke som fyller Londons gater, massen av folk som ikke engang har noen funksjon i industrimaskineriet. De er overflødige, både som arbeidskraft og som mennesker. Det humane er å hjelpe dem til å dø. De 
lider. Ikke bare i kroppslig forstand, men livene deres er meningsløse, og dette er en form for eksistensiell lidelse.

Dette sammenfallet, denne glidningen mellom det livet som (fra et bestemt perspektiv) er formålsløst og det livet som bør avsluttes, gir gjenklang i samtiden. I 1920 ga legen Alfred Hoche ut en liten bok (Binding \& Hoche, 2012), skrevet av ham selv og juristen Karl Binding, om liv som ikke var verd å leve (på tysk het den Die Freigabe der Vernichtung lebensunwerten Lebens, mer eller mindre «Om å tillate ødeleggelsen av liv som ikke er verd å leve», eventuelt «livsuverdig liv»). Resonnementet begynner med de menneskene som lider uutholdelig, de terminalt syke, men favner også utviklingshemmede («idioter» i datidens terminologi) som lever det forfatterne anser som meningsløse liv.

I Lawrences scenario virker de som ledes inn i dødskamrene, klar over hva som skjer. De er takknemlige. Det er viktig å huske at de ikke er dehumanisert - ikke slik vi ofte tenker betydningen av ordet. Dehumanisering kan skje ved at man nekter å møte den andres blikk og anerkjenne dennes status som menneske og individ. Dette er ikke Lawrences poeng. Han tror han ser menneskene han beskriver, bedre enn de ser seg selv. Det er derfor en human handling han er med på å utføre; han har gitt dem det de egentlig vil ha, om de ikke har maktet å uttrykke det.

Ikke dehumanisering, altså, men en vurdering av hva som er humant for hvem, og hvordan menneskeliv skal verdsettes. Lawrence vil bevare og foredle en bestemt forestilling om det menneskelige, om hva det menneskelige skal være, og i humanismens navn setter han opp et regneark, et regnskap. Hoche og Binding anser seg også, i sin bok, som empatiske og humane og rasjonelle. Det er en høyst sekulær og moderne innstilling. Fra dette synspunktet finnes ikke noe liv etter dette, ingen hinsidig tilværelse som rettferdiggjør drapene. Det er bare det at noen liv ikke bør leves, fordi de ikke kan være fullverdige menneskeliv. De er en eksistensiell utgiftspost.

\section{Inn i vår tid: Mediefortellinger og deres premisser}

Lawrences bilde skinner med et uhyggelig historisk og litterært lys som også når vår samtid, dens nyhetssaker, dens mediefortellinger om 
døden. Det opplyser noen av premissene for en del samtidig journalistisk historiefortelling, en form for historiefortelling som sjelden vil eller kan tydeliggjøre sine premisser. Mediefortellinger er på sitt mest virkningsfulle når de spiller på lag med uuttalte verdimessige antakelser og fordommer, slik blant annet diskursanalytikeren Norman Fairclough (2015) har vist. Dette styrer både hvordan fortellinger blir lagt frem, og hvilke som blir lagt frem, også fortellinger som handler om å være takknemlig for døden, fortellinger som feirer døden.

Brittany Maynard tok livet av seg i Oregon ved hjelp av denne delstatens lov om legeassistert selvmord. Det var i 2014. Maynard var ung og, på alle bildene som ble spredt i media, vakker og lykkelig. Hun hadde uhelbredelig hjernesvulst. Hun døde 1. november det året, slik hun hadde planlagt. Jeg skriver ikke nå om det som faktisk hendte - det kan jeg ikke vite, det kan praktisk talt ingen av oss - men om det vi ble fortalt, vi som leste amerikanske og norske nettaviser.

Dette var fortellingen slik den ble fortalt: en tragisk historie med en tross alt lykkelig slutt. Sorgmunter, full av katarsis. Til å gråte av og til å gå oppløftet videre fra. I denne fortellingen døde Maynard det året hun ble diagnostisert, men ikke før hun hadde reist jorden rundt. Hun hadde undervist på barnehjem i Nepal, giftet seg, hatt rike dager. I denne historien sto det siste kapittelet i skarp kontrast til de første, og det var kontrasten som gjorde historien levende, som gjorde den tragisk, men også vakker. Hun halte ikke ut lidelsen; hun ga oss som ikke kjente henne, et vakkert minne.

Vår tids kampanjer for dødshjelp er humane og humanistiske prosjekter. Det er de nødt til å være, noe annet er politisk umulig - foreløpig. De handler om å minimere lidelse og om å beskytte rettigheter, eller - rettere sagt - én rettighet, nemlig retten til å dø. Den retten er forankret i et liberalt prosjekt, ikke statlig-autoritært. Det er en rett til handlefrihet, men også i et eksistensialistisk prosjekt; det er retten til å styre sin livsfortelling gjennom å bestemme hvordan den skal ende.

Det underlige ved denne rettigheten er hvor avgrenset eller omfattende den kan fremstå, avhengig av hvilket perspektiv man anlegger. For noen er den individuelt avgrenset og gjelder bare enkeltmennesker. Retten til å gå ut av tiden er så personlig betydningsfull at den må være absolutt, 
den må trumfe alt annet. Dette er perspektivet som ofte går igjen i mediefortellinger: Kan man lese historien om Inger Staff-Poulsen eller Brittany Maynard og si nei, du får ikke lov?

Sett fra et annet perspektiv vil enhver slik rettighet fordre plikter av andre mennesker og store strukturelle samfunnsendringer. Skaper vi et samfunn som er innrettet på å utøve dødshjelp i organiserte former, følger det konsekvenser av dette. Det handler om en leges eller en psykologs plikt til å gi en vurdering, til å skaffe visse medikamenter til veie, til under visse omstendigheter å være til stede i et rom. Det handler om hvilke konsekvenser innføringen av en rettighet vil få for profesjonsutøvelse (se kap. 9). Fortellinger om mennesker har sjelden bare én skikkelse; de involverer både hovedpersoner og viktige bifigurer.

Normer endrer seg, det samme gjør lover. Under visse omstendigheter lar samfunnet seg forandre. Da åpner et rom seg som ikke tidligere var åpent. Vi vet ikke hvordan det vil se ut. Historier endrer seg etter hvilken slutt de får. Brittany Maynards historie fikk en vakker slutt - det vil si, en estetisk og moralsk tilfredsstillende slutt - og ble dermed en sann tragedie. Et lengre sykeleie, en mindre planlagt og mer tilfeldig død ville vært annerledes, og dermed ville hele historien vært annerledes, og neppe heller verd å fortelle i media. Hun valgte ikke antagonist eller dramaturgisk forløp, men hun valgte utfallet og skapte dermed også et rom for katarsis, for renselse - for andre. Det var hennes liv, men det var mange av oss som betraktet det utenfra og lette etter en moralsk leksjon, etter en læresetning. Med moralen blir historien til en fortelling. Den blir lettere å huske, lettere å bære med seg og lettere å gjøre til sin egen.

Skjønt, til sin egen? Brittany Maynard er død, og det er vi, du som leser (her, nå) og (forhåpentligvis, fremdeles) jeg som har skrevet, som må fortolke, internalisere, gå videre. Døden handler ikke om døden, den handler om livet. Den handler om hva det vil si å være menneske.

\section{Fortellingenes kraft}

Fortellingen om den nødvendige, lykkelige døden fortelles igjen og igjen. Den moralske leksjonen består i at dette er det menneskelige: det å velge avslutningsøyeblikket selv, alene, autonomt. Dette er den humane retten 
å gi andre. Seg selv gir man en historie man kan være bekjent av: passe lang, passe velformet, uten unødig lidelse. Klipp av tråden før den ryker. Slike fortellinger dukker jevnlig opp i media, som her, fra Dagbladet.no:

Tittel: «14 år gammel med uhelbredelig sykdom. Har et siste ønske og det får hun oppfylt.»

Undertittel: «Gir opp kampen mot muskelsykdommen.»

Jeg klikket på saken mot bedre vitende; jeg ville ikke egentlig vite hvilken muskelsykdom det var snakk om. Jeg har en muskelsykdom selv, en som det heter - uhelbredelig sykdom. Noen ganger vet jeg med sikkerhet at min situasjon er unik, at jeg ikke automatisk hører til i en gruppe eller klasse mennesker bare på grunn av en diagnose. Andre ganger er jeg mer usikker. Det er slik det er med identitet og identifikasjon; det varierer med omstendighetene.

Selv sier jeg ikke «sykdom» så ofte. Jeg trenger det ordet til jeg føler meg syk, til jeg har influensa, til noe annet skulle skje. Min uhelbredelige sykdom er en grunntilstand, en funksjonsnedsettelse. Disse ordene forsøker å favne noe permanent, et utgangspunkt, som ikke er uproblematisk, men som heller ikke har så mye til felles med sykdomsbegrepet slik det vanligvis brukes.

Sykdom er unntak, progresjon, dramaturgi og fortelling. Det jeg har, stedet der jeg befinner meg, er noe annet. Den britiske sosiologen Tom Shakespeare har brukt ordet predicament. Det er et godt ord på engelsk. På norsk nøler jeg. En «knipe» er det ikke riktig, det å være født med en slik muskelsykdom, for da er hele livet en knipe, og det er en historie jeg ikke ønsker å fortelle om meg selv. «Situasjon» er for nøytralt. Det er en serie utfordringer det er snakk om her, av varierende alvorsgrad, det er å ikke riktig få tak om det man griper etter. Dette kan være et glass med vann, det kan også være en livbøye.

Dermed får det bli omskrivningen (og eufemismen) «vanskelig livssituasjon»; det er det jeg snakker om. Med Lawrences terminologi er jeg nok heller en av the halt enn en av the sick. Jeg går noen skritt, jeg bruker en elektrisk rullestol, jeg har vondt i anklene.

Litt mer av mediefortellingen om en annen, fra Dagbladet.no (Borgstrøm, 2016), som fortalte den slik: 
Den amerikanske tenåringen Jerika Bolen, gir opp kampen mot muskelsykdommen spinal muskelatrofi type 2. (...) 14-åringen har bestemt at hun har lyst til å avslutte livet etter sommeren. Det er et valg hun har tatt, mens hun enda har muligheten til å formidle sine ønsker.

Ah. Det var spinal muskelatrofi. Det var den sykdommen. Type 2, riktignok. Diagnosen min var en gang spinal muskelatrofi type 3. Jeg skriver «var», fordi jeg fikk en ny diagnose. Den kliniske genetikken hadde blitt mer presis, nye markører lot seg identifisere. Men fra begynnelsen av åttitallet og i nesten tre tiår var det spinal muskelatrofi jeg hadde, det var navnet på den «vanskelige livssituasjonen» jeg befant - og befinner meg i.

Fortellingen om Jerika Bolen hadde en tydelig dramaturgi. Det dreide seg om en kamp. En fortelling om å kjempe, om å tape, men å tross alt vinne en liten seier - autonomiens seier - $\mathrm{i}$ selve nederlaget. Det er seieren som ligger i selvvalgt død, det er dødens triumf.

Jenta «feirer livet med et ball». Der var det: la musikken spille opp. D. H. Lawrence tok feil, det er ingen som trenger å ledes. The sick, the halt, and the maimed. De går selv.

Jeg var skeptisk til Lawrence lenge før jeg leste hva han mente om eugenikk. Jeg hadde tross alt lest Lady Chatterley's Lover (1928), og reagert mildt sagt negativt på hvilket syn den målbar på kropp og vitalitet, hva den postulerte av sammenheng mellom styrke og verdi. Det handlet om litterær identifikasjon. Jeg hadde lite eller ingenting til felles med Mellors, den vitale viltvokteren. Clifford Chatterley, derimot, den krigsskadde, bitre antagonisten av en ektemann:

He could wheel himself about in a wheeled chair, and he had a bath-chair with a small motor attachment, so he could drive himself slowly round the garden [...] Having suffered so much, the capacity for suffering had to some extent left him. He remained strange and bright and cheerful, one might say, chirpy, with his ruddy, healthy-looking face, and his pale-blue, challenging bright eyes. [...] Yet still in his face one saw the watchful look, the slight vacancy of a cripple.

Som så ofte ellers i kanoniske litterære sammenhenger: Det er ikke mye å hente for oss krøplinger. På den annen side - Lawrence lot i hvert fall Clifford Chatterley gjennomleve en slags karaktermessig utvikling. Han 
finner sammen med hushjelpen, Mrs. Bolton, i en slags pervertert utgave av det Constance Chatterley opplever med viltvokteren. Så det skal han ha: Lawrence ville gjøre kort prosess med de virkelige funksjonshemmede, men var mer nennsom med sin egen karakter.

En siste fortelling, fra populærlitteraturen denne gangen. Jojo Moyes skrev romanen Et helt halvt år, originaltittel Me Before You (2012), og den ble en suksess i Norge slik den hadde blitt det $\mathrm{i}$ andre land. Bastion forlag feiret dødens triumf på hovedpersonens vegne:

Will Traynor vet at motorsykkelulykken tok fra ham viljen til å leve. Han vet at alt føles veldig smått og meningsløst, og han vet nøyaktig hvordan han skal få slutt på det.

Det vet han, og det gjør han. Bokens heltinne gir ham et helt halvt år med romantikk og magi, men når det kommer til stykket, reiser han like fullt til Sveits, til Dignitas, og tar livet av seg. Det er trist, men - for å følge formen - usigelig vakkert. Denne narrative estetiseringen av den gode døden er, igjen ifølge forlaget, lest av mange hundre tusen nordmenn. Da filmen kom, var det med vakre skuespillere og en produksjonsdesign som tatt ut av de glatteste, dyreste livsstilsbilagene. Jeg har til gode å finne en så glamorøs feiring av døden; det er så man skulle tro det var en reklame.

Hva er det som driver denne dødsbejaelsen? Jeg leter fremdeles etter gode svar. Det er ikke den gamle religionen. Lawrences aggressive vitalisme tilhører den sekulære moderniteten, og det samme gjør den nye bevegelsen for dødshjelp. Flere markante motstandere av dødshjelp er religiøse; noen er ateister. Men selve dødsbejaelsen virker for meg å være beslektet med en sekuloer religion, slik dette fenomenet blir forstått blant annet av filosofen John Gray (Gray, 2018). Sekulær, rasjonalistisk, nyliberal, utilitaristisk: en ny religion, en ideologisk nyskapning med gamle, krokete røtter. Det handler om å unngå lidelse, om å maksimere det gode liv.

Dagbladet.no, august 2016: "ALS-syke Betsy inviterte til en siste fest før hun begikk legeassistert selvmord. Der var det bare én regel: «Ingen grining foran meg.» En lykkelig slutt. Saken hadde noen kritiske bemerkninger, det bringes opp bekymringer fra funksjonshemmedes organisasjoner i California. Bildene viser en smilende Betsy, omgitt av venner og 
familie. I den politiske prosessen frem mot legalisering av legeassistert selvmord i California inngikk også vitnesbyrd fra Brittany Maynard.

Jeg skriver ikke om de virkelige menneskene her. Dette er viktig. Jeg kjenner ikke de virkelige menneskene. Ikke Brittany, ikke Jerika, ikke Betsy. Jeg kjenner ikke kroppene deres. Det gjorde heller ikke Dagbladets journalist eller den amerikanske publikasjonen saken ble oversatt fra. Dette handlet ikke om selve døden, men om hvordan vi forteller historier om død.

I teksten finnes ikke spy og blod og panikkangst og smerte. Ikke i bildene heller, i de eksemplene jeg nevner. De viser milde smil og trette blikk. Kroppene, de virkelige kroppene, de som bare lever én gang og så er borte for alltid, er aldri tilstrekkelig til stede i teksten. De har ingen plass i mediefortellingene. De virkelige kroppene ville gjøre de lyse, luftige, dødsbejaende fortellingene umulige. Gladsaker illustreres ikke med Brueghel-malerier.

\section{Avslutning. Udødelighetens illusjoner}

Hva er formålet med eksistensen, hva lever vi for? Er det meningsfylt å bruke vår tilmålte tid på noe annet enn å etterstrebe udødelighet, siden fruktene av all annen anstrengelse - gleder, sorger, nytelse, kunnskap og kjærlighet - vil forsvinne sammen med den som har strukket seg etter dem? Mange religioner har et pose-og-sekk-svar: Udødeligheten kommer til den som lever riktig her og nå, i tanke og/eller gjerning. Den sekulære moderniteten har derimot ikke funnet noen løsning på dilemmaet, men i stedet endt opp med en slags optimaliseringskrise. Svært mye av den moderne statens virke er giret inn på å maksimere livskvaliteten vår fra unnfangelse til grav. De positive konsekvensene er mange, som bedre trafikksikkerhet og kosttilskudd til gravide, men parallelt styrkes mekanismene for å abortere - eller avslutte, ved dødshjelp - det sub-optimale livet.

Dødshjelp og drømmen om udødelighet er motpoler. Likevel møtes de, på underlig vis, i en roman av en annen klasse enn Et helt halvt år. Don DeLillo skriver i romanen Zero K (2016) om udødelighetsdrømmen som ikke helt kan skilles fra dødsdriften, om hvordan begge disse fantasiene har å gjøre med vår senkapitalistiske, tekno-utopiske, kosmopolitiske 
samtid. Det er en roman som handler om perfeksjon, og om å ta avstand til livet og dets vedvarende problemer.

Handlingen i denne boken er enkel, nesten skisseaktig. Jeffrey Lockhart reiser til ørkenen, til et kryogenisk laboratorium midt i Kasakhstan. Der er faren hans, en verdensmester av en milliardær, i ferd med å ta farvel med sin dødssyke kjæreste. Hun vil la seg fryse ned, sove til det utvikles en kur for sykdommen hennes, for så å våkne opp i en vidunderlig ny verden. Dreiningen i boken, det kan knapt kalles en overraskelse, gjelder Jeffreys far. Han bestemmer seg for også å la seg fryse ned, selv om det ikke er noe galt med ham. Kanskje nettopp derfor: Skal han tines opp, er det bedre om han lar seg fryse ned $n a ̊$, før det kroppslige forfallet rammer ham, slik det rammer oss alle, før det gjør livet prinsipielt utålelig.

Zero $K$ - null grader Kelvin, det absolutte nullpunkt - er naturlig nok en kjølig bok. Den er ikke uten humoristiske innslag, men er ført i den samme, poetisk-kliniske tonen som DeLillo særlig har rendyrket de siste tiårene. Man kan gripe romanen an med utgangspunkt i Edward Saids tanker om late style. Said hevdet at hos mange kunstnere som nærmer seg slutten av karrieren, nærmer seg døden, er det slik at visse stilistiske enkeltelementer blir rendyrket og gjort underligere. Beethovens musikk blir mer preget av det uventede, av dissonanser, Shakespeares stykker blir underligere, åpnere, mørkere. Late style preger en kunstner som mestrer de kjente formene, men vil søke inn i det ukjente. Samtidig er det en elegisk form. Det er en sørgesang for livet, som likevel er noe ganske annet enn en sang om dødens triumf.

Zero K er en spøkelseshistorie uten det eksplisitt overnaturlige elementet, den søker mot det transcendente og mystiske uten å forlate den materielle verden vi lever i. Som sagt: Bare milliardærer er garantert å komme til himmelen.

I virkeligheten finnes det jo en håndfull mennesker som tror på udødeligheten, flere av dem fra den globale middelklassen og enkelte av dem nordmenn, som abonnerer på tjenestene til kryogenikk-firmaet Alcor. Når én av disse siste dagers heldige sjekker ut, sjekker de samtidig inn i en tank med frostvæske i Arizona, forutsatt at alt går etter planen - som jo er logistisk krevende. To millioner kroner til et amerikansk firma er en noe høyere innsats enn vi er vant med fra norsk helsevesen, men det er jo 
forståelig at noen vil satse likevel. Større beløp tapes på børsen hver dag, om enn ikke av de fleste av oss.

DeLillo stiller det underliggende spørsmålet, det jeg gjerne skulle hatt besvart: Hvorfor er det ikke flere som reiser til Arizona nå, mens de ennå er friske og sunne? Om man først tror, bare litt, på kryogenikkens potensielle mirakel, er det ikke da fryktelig risikabelt å vente til man har lungekreft i fjerde stadium eller har snublet ut foran bussen? Jeg har reist en del rundt i verden med en stor elektrisk rullestol. Basert på hva som jevnlig har skjedd med den på vei inn og ut av bagasjerommet, er jeg nysgjerrig på hvordan den siste transportetappen vil forløpe for kryogenikerne.

Når det kommer til stykket, har teknologioptimismen en appell som minner om religionens. Vi tror, absolutt og helt sikkert, at vi skal bli frelst. Men både Gud og singulariteten er fjerne. Vi drømmer om frihet fra kroppslig forfall, fra politisk kamp og fra stadig strev. DeLillo beskriver denne drømmen, kontrasten mellom de antiseptiske omgivelsene i ørkenen og de skitne gatene hjemme. Han beskriver de rike, triste menneskene som er på vei ned i kryogenisk limbo, flytende i væske, nakne og hårløse. I grunnen beskriver han en livmor, og kanskje lengter vi alle tilbake til det stadiet. Uten sorger, uten dødsbevissthet.

Dette kapittelet har søkt utover de umiddelbare og institusjonelt forankrede problemene knyttet til dødshjelp. Det har tematisert noen av fantasiene og fabuleringene som oppstår rundt disse temaene; jeg tror ikke vi kommer utenom disse. Døden er, som flere filosofer har påpekt, prinsipielt utenkelig. Det vil si at vi kan verken forestille oss eller forstå vår egen død. Lev Tolstojs novelle Ivan Iljitsj' død tematiserer denne umuligheten. Den handler om et menneske som dør, og om hvordan det i menneskene rundt ham, sammen med mange andre følelser, oppstår en slags underlig lettelse over at døden - i hvert fall denne gangen - er noe som rammet ham, en annen, ikke dem.

Fortellinger om dødshjelp løftes frem av mange årsaker. Jeg skal være den siste til å mistenkeliggjøre de som selv vil fortelle om sine valg, om sine ønsker. Men jeg tror vi er tjent med å se nøye på hvilke rammer som tilbys, hvilke mønstre som finnes i kulturen. Fortellingen om den gode død er nettopp det, en fortelling, som også kan være egnet - og ment - til å la oss andre leve bedre med oss selv, og vår verden. Inntil videre. 


\section{Referanser}

Binding, K. \& Hoche, A. (2012). Allowing the destruction of life unworthy of life: Its measure and form. Suzeteo Enterprises.

Borgstrøm, H. (2016, 25. juli). 14 år gammel med uhelbredelig sykdom. Har et siste ønske og det får hun oppfylt. Dagbladet.

Boulton, J. T. (1979). The letters of D. H. Lawrence, vol. I, 1901-1913. Cambridge: Cambridge University Press.

Carey, J. (2012). The intellectuals and the masses: Pride and prejudice among the literary intelligentsia 1880 -1939. New York: Faber \& Faber.

DeLillo, D. (2016). Zero K. New York: Simon \& Schuster.

Didion, J. (1979). The white album. New York: Simon \& Schuster.

Fairclough, N. (2015). Language and power. London: Routledge.

Gray, J. (2018). Seven types of atheism. New York: Farrar, Straus and Giroux.

Grue, J. \& Moen, O. M. (2016). En brevveksling på liv og død. Morgenbladet. Hentet fra https://morgenbladet.no/aktuelt/2016/10/en-brevveksling-pa-liv-og-dod

Lawrence, D. H. (1928). Lady Chatterley's lover. Firenze: Tipografio Giuntina.

Moen, O. M. \& Sterri, A. B. (2019). Aktiv dødshjelp. Etikk ved livets slutt. Oslo:

Cappelen Damm Akademisk.

Moyes, J. (2012). Me before you. London \& New York: Penguin.

Staff-Poulsen, I. (2019, 2. februar). Vedlagte kronikk er kanskje litt kontroversiell fordi jeg er død. Dagbladet. Hentet fra https://www.dagbladet.no/kultur/vedlagtekronikk-er-kanskje-litt-kontroversiell---fordi-jeg-er-dod/70706493

\section{Ordforklaringer}

heller: snarare/snarere (S/D)

nøle: tveka (S), tøve (D)

passe: lämplig (S), tilpas (D)

sendrektig: förhalande (S), henholdende (D)

tines opp: tina upp (S), blive optøet (D)

vrimlende: myllrande (S), myldrende (D) 

Del III

Klinikk 



\title{
KAPITTEL 9
}

\section{En leges nei til dødshjelp}

\author{
Morten A. Horn
}

Oslo universitetssykehus

\begin{abstract}
While there is broad support for assisted dying in the general public, many doctors say no - no to performing it, no to legalising it. What explains this resistance? This chapter deals with the counterarguments against assisted dying, from a professional ethics standpoint and a doctor's outlook. I will present the eight main reasons why I as a doctor say no to euthanasia. The same reasons can be found in declarations on assisted dying from medical and specialist associations worldwide. A recurring feature is that they do not necessarily presuppose a categorical rejection of assisted dying as an isolated phenomenon, or a morally grounded rejection of the euthanasia act. The most important concern is how the doctor will be able to cope with the extremely difficult question of whether another person should be helped to die. At the same time the doctor must preserve the care of vulnerable individuals, as well as the doctor's own role and values.
\end{abstract}

Keywords: assisted dying, euthanasia, legalisation, medical ethics, physicianpatient relationship, professional ethics

\section{Innledning}

Motstand mot dødshjelp er utbredt blant leger. Avvisningen av dødshjelp kan føres tilbake til Hippokrates, men står sterkt også i dag (Gaasø, Rø, Bringedal \& Magelssen, 2019). Det norske Rådet for legeetikk uttalte at «Aktiv dødshjelp er det motsatte av det leger skal drive med» (Hytten \& Aarseth, 2015). Samtidig er det bred oppslutning blant nederlandske leger om landets eutanasilov (Kouwenhoven, van Thiel, van der Heide, Rietjens \& van Delden, 2019). Også i de nordiske landene er en betydelig andel av legene positive til dødshjelp.

Sitering av denne artikkelen: Horn, M. A. (2020). En leges nei til dødshjelp. I M. A. Horn, D. J. H. Kleiven \& M. Magelssen (Red.), Dødshjelp i Norden? Etikk, klinikk og politikk (Kap. 9, s. 175-192). Oslo: Cappelen Damm Akademisk. https://doi.org/10.23865/noasp.96.ch9.

Lisens: CC BY 4.o. 
Den akademiske diskusjonen rundt dødshjelp handler gjerne om empiriske studier av dødshjelpspraksis i land som har legalisert det, eller normative filosofiske analyser av om dødshjelp er akseptabelt eller ikke. Denne diskusjonen kan settes inn i større etiske rammeverk, og den kan vurderes i lys av ulike filosofiske skoler. Selv om slike analyser er interessante, risikerer de å gå glipp av det som for mange er hovedpoenget med dødshjelp. For tilhengerne kan det være så enkelt som at «det er mitt liv, min død». Omvendt sa en kollega til meg om sitt dødshjelps-nei: «Det var ikke derfor jeg ble lege.»

I dette kapitlet vil jeg trekke fram verdi- og erfaringsbaserte argumenter for hvorfor legalisering av dødshjelp blir feil, for meg som lege. Denne typen argumenter kan bare i liten grad underbygges av vitenskapelig evidens; de risikerer å underkjennes i akademiske tekster om dødshjelp. Eksempelvis avspises drøftingen av hvorvidt dødshjelp strider mot legeetikken, bare med et kort avsnitt i den svenske kunnskapssammenstillingen om dødshjelp (Statens medicinsk-etiska råd, 2017). Samtidig kan nettopp slike argumenter spille en stor rolle for holdningen til dødshjelp blant viktige aktører i debatten. De er derfor vel verd å se nærmere på.

Innledningsvis vil jeg redegjøre for konteksten kapitlet står i. Dernest vil jeg legge fram de viktigste grunnene til at jeg som lege er motstander av å legalisere dødshjelp i Norge.

\section{Kontekst}

Dette er et personlig, medisinsk-etisk essay om én leges syn på dødshjelp, og det inngår i en tradisjon der essays fra Ilora Finlay (2009) er blant de fremste eksemplene. Jeg som skriver, er mann, 50 år og har et sekulært (humanetisk) livssyn. Min tenkning om dødshjelp er preget av at jeg i mer enn tjue år har jobbet som nevrolog, blant annet i teamet som behandler pasienter med amyotrofisk lateralsklerose (ALS) ved Oslo universitetssykehus. Jeg har ikke selv utført dødshjelp, men hadde som ung lege en «nær dødshjelps-opplevelse», der jeg vurderte om jeg var nødt til å ty til dette (situasjonen løste seg da jeg forsto at jeg kunne øke morfindosen uten å ta livet av pasienten). 
Jeg skriver ut fra en norsk kontekst - der dødshjelp er eksplisitt forbudt i straffeloven (se kap. 3), hvor lovforbudet mot assistanse til selvmord har vært aktualisert i en rekke saker mot legfolk, men hvor kun én lege har blitt domfelt for dødshjelp (Sandsdalen-saken fra 1996). Spørreundersøkelser gir et bilde av at illegal dødshjelp er lite utbredt i Norge (Førde \& Aasland, 2014), og jeg har selv aldri hørt en kollega innrømme å ha utført dødshjelp. Meningsmålinger blant norske leger viser at et flertall er mot å legalisere dødshjelp, mens en meget liten andel (9 \%) er sterkt for. En tilsvarende liten andel ville vært villig til å utføre handlingen om det var tillatt (Gaasø et al., 2019).

Mange norske leger svarer at de er delvis for, delvis mot, eller usikre i spørsmålet om legalisering. Jeg tror dette illustrerer at man som lege kan ha et tvisyn på dødshjelp: Man kan se både argumenter for og argumenter mot, og jeg vil tro at de fleste klinikere vil kunne se for seg situasjoner der dødshjelp ville vært det minste av flere onder. Man må skille mellom legers holdning til dødshjelp som konkret handling i en gitt situasjon, og holdningen til legalisering av dødshjelp på samfunnsnivå.

I Norge har vi gode alternativer til dødshjelp gjennom en liberal pasientrettighetslov fra 1999, som gjør det klart at pasienter kan takke nei til livsforlengende behandling. Dette omfatter også avslutning av respiratorbehandling, for eksempel ved ALS (Holmøy et al., 2009). På den annen side er den palliative omsorgen i Norge dårlig utbygd (se kap. 10). Det er spesielt dårlig stelt med palliasjon til ikke-kreftpasienter, som de nevrologiske. Her i landet har vi en uttalt målsetting om å forebygge og forhindre selvmord, som særlig pålegger leger (gjennom helsepersonelloven) en plikt til aktivt å motvirke at pasientene deres begår selvmord.

\section{Argumenter mot legalisering av dødshjelp}

De to hovedargumentene for dødshjelp er barmhjertighet og autonomi. Ved livets slutt kan lidelsen være stor, og vi når ikke alltid fram til målet med lindrende tiltak. Legen kunne hatt nytte av et verktøy, en sprøyte gjemt aller nederst i legekofferten, som kunne tas fram i tilfeller av uutholdelig, uhåndterbar lidelse ved livets slutt. En slik opsjon kunne kanskje tjene velgjørenhetsprinsippet (beneficence), hvis man aksepterer 
premisset om at det er bedre å ikke lide fordi man ikke lever, enn å lide og leve. Man kan tenke seg at konsekvensene av å trå feil (ikke-skade-prinsippet) ikke er så store dersom dødshjelp er noe som ytes i livets aller siste timer og dager.

Likeledes er prinsippet om respekt for pasientens autonomi grunnleggende for oss leger, slik autonomi også er en kjerneverdi i det moderne vestlige samfunn (Materstvedt, 2019). Dersom individet har et sterkt ønske om å få råde over når og på hvilken måte livet skal avsluttes, ville det i utgangspunktet kunne være velgjørende om medisinen kunne bistå pasienten i å utøve sin autonomi.

Barmhjertighet og autonomi er altså gode argumenter for hvorfor det, sett fra legens ståsted, kunne vært greit om dødshjelp var lovlig. Når jeg som lege er dødshjelpsmotstander, handler det ikke om at jeg ikke ser eller anerkjenner disse argumentene for, men at argumentene mot er flere og sterkere. Det er framfor alt argumentene mot legalisering - og faren for at legalisering vil føre til institusjonalisering av praksisen, og i neste instans en normalisering av det som egentlig var ment som en nødrettshandling (Materstvedt, 1998), som motiverer min dødshjelpsmotstand. Jeg vil se nærmere på de åtte argumentene som etter min mening er de aller sterkeste.

\subsection{Arven etter Hippokrates}

Legene Blomkvist og Zadig angrep i fjor bruken av den hippokratiske legeeden som argument mot legalisering av dødshjelp (Blomkvist \& Zadig, 2018). I eden står det: «Jeg skal ikke gi noe dødelig legemiddel til noen eller gi råd om noe slikt.» Denne eden, som er flere tusen år gammel, forbyr også abort og kirurgi, og framstår i dag som foreldet. Den moderne legeeden, Genève-erklæringen, inneholder ikke noe eksplisitt forbud mot dødshjelp. Blomkvist og Zadig mente det var utdatert å trekke Hippokrates inn i den moderne dødshjelpsdebatten.

I debatten som fulgte, påpekte jeg at dette konkrete forbudet mot dødshjelp ikke er det sentrale i arven fra Hippokrates (Horn, 2018). Det viktigste hippokratiske budet er ikke-skade-budet. Det lever i beste velgående i dag, og utgjør ett av de fire medisinsk-etiske grunnprinsippene. 
Ikke-skade-prinsippet kan tolkes på flere måter. Den mest opplagte er at vi leger ikke skal skade våre pasienter - som ved å ta pasientens liv gjennom eutanasi. Men det har også en dypere betydning: Plikten til ikke å skade er også en plikt til ikke å gjøre skadelige feil. Det å yte dødshjelp til en pasient som egentlig ikke skulle hatt hjelp til å dø, men burde vært hjulpet på en annen måte - det ville bryte med ikke-skade-prinsippet. Dette preger mange legers holdning til dødshjelp, også der det er legalt: De strever med beslutningen de må fatte, og er bevisst på hvor irreversibel skaden er, om de velger feil (Kelly, Handley, Kissane, Vamos \& Attia, 2019; van Marwijk, Haverkate, van Royen \& The, 2007; Emanuel, Onwuteaka-Philipsen, Urwin \& Cohen, 2016). De kan også frykte å skjøtte selve avlivningen feil - for eksempel ved at dødshjelpen ikke lykkes, at pasienten våkner opp i en fortvilet situasjon, eller at det blir en støtende dødsprosess grunnet oppkast, kramper eller lignende.

Jeg kjenner ingen leger som virkelig betrakter den hippokratiske legeeden som en autoritet i praktisk legevirksomhet. Hippokrates omtales mest i festtaler og som koloritt i medisinske artikler. Men ikke-skade-prinsippet er og blir en viktig føring for leger - og da ikke bare som et eksternt pålegg vi adlyder for ikke å havne i trøbbel. Det å ikke skade er også et internt bud vi som leger pålegger oss selv: Vi står i et yrke der vi håndterer syke og sårbare pasienter, potente og til dels risikable behandlingsformer, og der vi ofte geleider pasientene på grensen mellom liv og død.

Uttrykk som «livets ukrenkelighet» - i religiøs forstand - betyr lite for meg som sekulær lege. Men hvis jeg ikke er meg bevisst livets sårbarhet, og hvordan mine egne valg og handlinger kan bidra til å dytte pasienten over grensen til skade eller død, kan jeg ikke gjøre jobben min som lege. Legen som doserer warfarin, eller kirurgen som åpner brystkassen for å operere et hjerte, balanserer på en knivsegg med det klare mandat å gjøre vel, men med en like klar risiko for å gjøre skade. Som lege er jeg nødt til å ha et bevisst forhold til ikke-skade-prinsippet; det må være rotfestet $\mathrm{i}$ meg at jeg ikke skal være den som tar liv.

Jeg mener respekten for ikke-skade-prinsippet er den sanne arven etter Hippokrates, og at vi leger bør holde dette prinsippet i hevd. Det å åpne for dødshjelp, og især dødshjelp satt i system som legalisert, institusjonalisert handling (i motsetning til noe man tyr til i nødstilfeller, i 
desperasjon), innebærer etter mitt syn å utfordre ikke-skade-prinsippet. Det vil rutinemessig plassere leger i en situasjon der vi må fatte avgjørelser vi vet er vanskelige, og hvor resultatet av feil valg blir det verst tenkelige: Pasienten vår dør. Hvis dødshjelp skal innføres - utført av meg eller av en kollega - trengs det bunnsolide systemer som sikrer at rett pasient får dødshjelp på medisinsk forsvarlig måte. Klarer vi det?

\subsection{Legerollen og synet på lidelse}

Legens oppgave er å redusere pasientens lidelse så langt råd er. Men dette kan ikke reduseres til en kamp mot lidelse som sådan; lidelsen er ikke bare en fiende som legen skal eliminere. Legens jobb er, like mye og i mange tilfeller, å hjelpe pasienten med å stå i og holde ut lidelsen - den lidelsen som ikke lar seg fjerne. Det er ikke fraværet av lidelse som er medisinens mål, men størst mulige velvære for pasienten. Det å eliminere lidelse ved å eliminere den lidende, er meningsløst.

Som lege - som nevrolog - er jeg vant til å møte pasienter som lider. Min rolle i slike møter er sammensatt. Selvsagt forsøker jeg å eliminere årsaker til lidelse der det er mulig. Eksempelvis kan jeg henvise til operasjon av et prolaps som trykker på en nerverot, slik at isjiassmertene slipper taket. Jeg kan gi glykopyrroniumbromid til en ALS-pasient som lider av slim i luftveiene, slik at slimet tørker ut. Men dersom lidelsen hos den enkelte pasient ikke lar seg eliminere, er likevel ikke min jobb gjort, ei heller er den mislykket. I mange av mine pasientkontakter handler jobben min om å hjelpe pasientene med å takle, holde ut og leve med lidelse som ikke lar seg eliminere, kanskje ikke en gang redusere. Det å jobbe som lege innebærer å måtte akseptere lidelse som en naturlig og ofte uunngåelig (men selvsagt også uønsket) del av pasientens liv.

Som lege er jeg nødt til å forholde meg til lidelse som noe «aksepterbart», i en viss forstand, for lidelsen vil kunne være en uatskillelig del av pasientens eksistens. Det gjelder særlig lidelse som ikke er direkte smerte (som oftest kan lindres medikamentelt eller på andre måter), men som handler om funksjonssvikt eller psykososiale konsekvenser av sykdom. I møtet med den syke trenger jeg som lege å klare å stå i at lidelsen er der, uten at jeg av den grunn overgir meg - overgir pasienten. 
Det er forståelig at pasienter, og kanskje også samfunnet rundt dem, opplever det som uverdig ikke å kunne kontrollere urin og avføring. Denne opplevelsen kan være lidelsesfull i seg selv. Men hvis jeg som lege oppfatter inkontinens som noe uverdig - hvordan skal jeg da klare å behandle den inkontinente som et menneske med verdigheten i behold?

Som lege må jeg aktivt formidle et signal til så vel pasienten som til omverdenen: Jeg er en som avviser dette at verdighet kan kobles til funksjon, samtidig som jeg viser forståelse for pasientens opplevelse av dette. Bare slik kan jeg møte de som har et funksjonstap, uten at de føler seg vurdert eller nedvurdert.

\subsection{Lege-pasient-forholdet}

Lege-pasient-forholdet er basert på tillit. For at det skal ha noen hensikt, er både pasient og lege avhengig av at pasienten føler tillit til legen. Tillit til at legen er profesjonell, at legen vil deg vel, og at legen er ærlig. Ikke minst tillit til at legen vil bli hos pasienten, også når det går dårlig. Det er ikke alltid legen personlig kan følge en døende pasient hele veien. Men pasienten må føle seg trygg på at noen vil bli værende, at helsevesenet i utvidet forstand vil bli hos pasienten, holde i hånden, helt til siste slutt.

Talsmenn for dødshjelp har hevdet at tillatt dødshjelp kan styrke båndet mellom lege og pasient ved livets slutt: Det kan gjøre det tillatt for pasienten å snakke om døden, og om å framskynde døden, uten frykt for fordømmelse eller avvisning fra legen. Det er mulig dette er sant, og det kan være en grunn til at for eksempel nederlandske leger jevnt over er positive til at de har tilgang til dødshjelp.

Men det er også mulig, i land som ikke tillater dødshjelp, å oppnå denne åpenheten og ærligheten om døden i samtaler mellom lege og pasient. En nyttig tilnærming kan bygge på PLISSIT-modellen, opprinnelig en sexologisk intervensjonsmodell utviklet på 1970-tallet av Jack Annon (Annon, 1976). Den bygger på fire nivåer av detaljnivå og intervensjon: Permission, Limited Intervention, Specific Suggestions og Intensive Therapy. Selv om det er forskjell på å snakke med pasienten om seksualforstyrrelser og om døden, er fellestrekk for disse temaene at de er vanskelige, til dels tabubelagte emner som pasienten kan kvie seg for eller være engstelig for å ta 
opp med legen. Legen kan i samtalen med pasienten være tydelig på at det er tillatt å snakke om døden, om det å ha tanker om å framskynde døden, eller tanker om suicid eller dødshjelp, og for noen konkrete selvmordsplaner. Poenget med den PLISSIT-aktige tilnærmingen er at man går varsomt fram, steg for steg, og gir pasienten stor grad av kontroll over hvor mye han/hun vil si om temaet.

Gjennom en slik varsom tilnærming blir det også mulig å utforske pasientens egne holdninger, forventninger og engstelige tanker om døden. Man kan oppklare misforståelser og hjelpe til med å planlegge døden på en måte som svarer til pasientens verdier.

Dersom legen som skal lindre og helbrede, også blir den som tar liv, vil det kunne få stor betydning for lege-pasient-forholdet. Når pasient og lege snakker åpent om pasientens ønsker om å avslutte livet, stilles legen overfor et valg: Skal man fremme håpet og livet, eller skal man gi støtte til den siden ved pasienten som ønsker å gi opp? Det kan være meget krevende for legen å stå i rollen som den som støtter opp om livet, som forsøker å finne løsninger der det virker håpløst, og som gir av seg selv for å hjelpe pasienten med å gjenfinne mening ved det å leve. Dersom det blir en akseptert og normal del av legerollen at legen også er den som hjelper pasienten med å gi opp, kan dette komme til å påvirke kontrakten mellom pasient og lege. Pasienter som vakler mellom suicidalitet og livsgnist, kan risikere å miste legen som en utvetydig alliert med livet og håpet.

Dersom dødshjelp blir legalisert, kan det også få konsekvenser for pasientens egen delaktighet i lege-pasient-forholdet. Selv om legen ikke vil yte dødshjelp, vil pasienten kunne få det andre steder. Legen vil kunne oppleve at pasienten plutselig blir borte - tapt til dødshjelp. Vissheten om denne muligheten vil kunne påvirke legens ubevisste investering i pasientforholdet. Det vil også kunne etablere en slags konkurransesituasjon, der legen hele tiden må strebe etter å «overby» dødshjelpslegen som den som best kan hjelpe pasienten. Dette vil være særlig krevende dersom et ikke-dødshjelps-forløp krever innsats og utprøvning fra både lege og pasient.

Det å være en lege som må si nei til dødshjelp, på grunn av lovforbudet, kan ses som en hemsko. Man er avskåret fra å kunne hjelpe pasienter med å få oppfylt deres siste desperate ønske. Men det gir også legen et solid 
rekkverk som gjør det mulig å stå oppreist i veldig vanskelige situasjoner, der stor lidelse eller psykososiale utfordringer gjør at pasienten trekkes mot håpløshet og dødsønske. Jeg ønsker som lege å fortsette som den som står for håp, løsning, lindring. Jeg ønsker ikke å la meg trekke med av pasientens virkelighetsoppfatning, hvor alt virker håpløst. Da tror jeg det vil være en styrke for meg at døren til den enkle utveien, dødshjelpen, er stengt.

\subsection{Konsekvenser for legespesialitetene}

I Nederland utføres de aller fleste (93\%) dødshjelpstilfeller av primærlegene (Kouwenhoven et al., 2019). Det er uvisst hvordan dette kunne bli gjort i Norge. Dersom dødshjelp skulle implementeres på faglig forsvarlig vis, skulle man forvente involvering av fagfolk med kompetanse på den aktuelle pasientens sykdom. Dersom prognose og behandlingsmuligheter skulle inngå i vurderingen av om dødshjelp var berettiget, skulle man vente at onkologer ble bedt om å uttale seg når det gjaldt kreftpasienter. Som nevrolog kunne jeg vente å få spørsmål om pasienter med amyotrofisk lateral sklerose (ALS), multippel sklerose (MS) eller Parkinsons sykdom.

I Norge dør i dag bare 15 \% i hjemmet - flertallet dør på institusjon (kap. 10). Det er tenkelig at legalisert dødshjelp ville bidra til at flere kunne dø hjemme, og i så fall gjennom dødshjelp administrert av fastlegen. Men slik dødsomsorgen er organisert i dag, er det sannsynlig at dødshjelp vil bli noe man forventer at spesialisthelsetjenesten skal håndtere.

Undersøkelser tyder på at motstanden mot dødshjelp er størst blant de spesialiteter som har mest å gjøre med pasienter som er typiske kandidater for dødshjelp - blant annet palliativmedisinere og kreftleger (Lindblad, Löfmark \& Lynoe, 2008; Craig et al., 2007; Roberts et al., 1997). Holdningen til dødshjelp blant norske nevrologer er ukjent, men en undersøkelse fra 2014 blant amerikanske nevrologer viste et flertall for å tillate legeassistert selvmord ved terminal sykdom (AAN, 2014).

Som nevrolog frykter jeg at legalisert dødshjelp vil gjøre at jeg stadig blir utsatt for spørsmål om dødshjelp - hvor jeg tvinges til enten å avvise pasientens ønske eller å bryte med min egen samvittighet. Det vil kunne bli et 
press om at sykehusavdelinger skal tilby lovlig dødshjelp til de som ønsker det. Dersom jeg reserverer meg, vil jeg påføre mine kolleger en ekstrabelastning. Denne problematikken har lenge vært kjent for norske gynekologer som ikke ønsker å utføre abort: Juridisk sett har man reservasjonsrett, men blir likevel som «hår i suppa» for et system som bygger på at alle bidrar. Jeg frykter at legalisert dødshjelp vil kunne føre til gradvis flukt av leger som ikke ønsker å delta. Hele fagmiljøer kan bli preget av pro-dødshjelps-holdninger, en dreining av fagets identitet. Det er ikke selvsagt at pro-dødshjelps-personer er de beste til å levere de andre tjenestene en spesialitet bør levere, og da spesielt ikke de som handler om «livshjelp».

\subsection{Selvmordsforebyggende arbeid}

Leger er både profesjonsetisk og etter helsepersonelloven forpliktet til å forebygge og om nødvendig forhindre selvmord. Blir dødshjelp tillatt, må vi håndtere det at noen skal hjelpes til selvmord, mens andre skal forhindres. Som beskrevet i kap. 11 er det betydelig overlapp mellom «vanlige» selvmordstruede pasienter og pasienter som ber om og får utført dødshjelp. Blant faktorene som predikerte et ønske om å framskynde døden blant ALS-pasienter, dominerte depresjon, angst, ensomhet, opplevelse av å være en byrde for andre samt lav livskvalitet (Stutzki et al., 2014). Det er altså de psykososiale konsekvensene av sykdom, mer enn de rent biomedisinske, som gjør at pasientene ønsker å dø - enten sykdommen er en organisk tilstand som ALS eller en rent psykisk lidelse.

På individnivå kan det være vanskelig, kanskje umulig, å avgjøre hvordan pasienten skal klassifiseres: Skal han/hun få hjelp til å dø, eller hjelp til å leve? Dette dilemmaet trenger vi ikke å hanskes med under dagens lovgivning, men en legalisering av dødshjelp vil tvinge leger til å forholde seg til det. Det er få eller ingen validerte verktøy som kan hjelpe legen til å fatte det riktige valget. Noen mener psykologer kan vurdere bedre enn leger hvem som bør få hjelp til å dø (Vigeland, 2009). Men psykologer med erfaring fra syke og døende pasienter kan se de samme utfordringer som leger gjør (Schjødt, 2010). Det vil uansett være den som utfører dødshjelpen, som i siste instans må være overbevist om at det er riktig å hjelpe pasienten med å dø. 
En dødshjelpslov vil kunne gi juridisk ryggdekning til leger i en slik vanskelig avveining: Den kanadiske loven slår fast at leger ikke skal straffes dersom de handlet i god tro (kap. 15). Men leger er ikke bare bundet av jussen. Jeg mener at vi også har en profesjonsetisk - og en medmenneskelig plikt til å ivareta sårbare mennesker i krise. Dersom jeg skulle gitt dødshjelp til en pasient som egentlig ropte om hjelp til å ville leve (Magelssen, 2016), ville det vært til liten trøst at jeg slapp straff. Den tyngste straffen ville ha vært at jeg hadde sviktet som lege og medmenneske da det gjaldt som mest.

\subsection{Hensynet til legens velferd}

Det er godt beskrevet at det å utføre, eller bare bli bedt om å utføre dødshjelp, kan oppleves som en tung belastning (Emanuel et al., 2016; Kelly et al., 2019; van Marwijk et al., 2007). En undersøkelse blant nederlandske leger viste at $86 \%$ fryktet for den følelsesmessige belastningen ved å utføre eutanasi (Emanuel et al., 2016). En annen studie fant at 15-20 \% av legene opplevde pågående negative effekter av å delta i dødshjelp (Kelly et al., 2019). Undersøkelser blant norske leger viser at bare $9 \%$ er villige til å utføre dødshjelp, dersom det blir tillatt i Norge (Gaasø et al., 2019). Forespørsler vil kunne komme fra pasienter over hele landet, og med et bredt spekter av sykdommer. Antallet personer som ønsker dødshjelp, vil kunne bli høyt. ${ }^{1}$ Det er sannsynlig at leger som ikke ønsker å bidra til dødshjelp, vil bli bedt om å gjøre det.

Det å følge sin egen samvittighet, og si nei til en sterkt lidende pasients innstendige bønn om hjelp til å avslutte livet på en skånsom måte, er ikke enkelt. Leger, også jeg selv, er vant til å sette hensynet til pasientene foran egne behov, enten det handler om å ta en pause for å spise mens man er på vakt, eller om prioriteringen av egen familie versus det å gjøre seg ferdig på sengepost og poliklinikk. Som lege er min misjon i livet å være til nytte

Omregning av 2018-tallene fra Oregon tilsvarer over 200 tilfeller av legeassistert selvmord i året $\mathrm{i}$ norsk målestokk - det er ukjent hvor mange som ber om det og får avslag. Omregning av nederlandske tall (der bare $80 \%$ rapporteres) tilsvarer ca. 1900 dødshjelpstilfeller årlig i Norge, minst like mange ber om dødshjelp uten å få det innvilget. 
for pasientene. Det ville være smertefullt å være den som sier nei, selv om det er av hensyn til mitt eget beste og min samvittighet.

Loven som forbyr leger å yte dødshjelp lager ikke bare en barriere for leger som ønsker å yte slik hjelp. Den gir også en beskyttelse til leger som motsetter seg å gjøre det, eller som tar skade av å gjøre det. Dette er én grunn til at leger som er mot dødshjelp for egen del, har god grunn til å være motstandere av legalisering.

\subsection{Legers samvittighetsfrihet}

I dødshjelpsdebatten tas det ofte for gitt at leger som ikke vil delta i dødshjelpen, skal kunne reservere seg. «Selvsagt skal ingen tvinges til dette», har jeg ofte hørt. Men denne forutsetningen er ikke nødvendigvis holdbar. Som vist over er det en klar risiko for at det kan oppstå et misforhold mellom pasienter som ønsker dødshjelp, og leger som er villige til å utføre det. Risikoen øker for land som Norge, med store geografiske utfordringer. I 2014 raste «reservasjonsstriden» rundt kristne fastlegers adgang til å reservere seg mot å henvise til selvbestemt abort. Da ble det klart at brede lag av folket ikke bare avviste, de ble også sterkt provosert av, legenes reservasjonsønsker. De ga klar beskjed om at leger som jobber for det offentlige, må tilby pasientene de lovlige helsetjenestene de har behov for. Dette gjenspeiles i en fersk, norsk undersøkelse, der bare $69 \%$ støttet legers rett til å reservere seg mot å utføre dødshjelp hvis det skulle bli tillatt (Barlaup, Landsverk, Myskja, Supphellen \& Magelssen, 2019).

Da et regjeringsoppnevnt offentlig utvalg utredet samvittighetsfrihet i arbeidslivet (NOU 2016:13), ble det lagt til grunn at dødshjelp var en så spesiell handling at forfatterne antok at reservasjonsretten ville bli respektert. Jeg betvilte dette (Horn, 2016a), og det gjenstår fortsatt å se: Dersom nordmenn ikke kan akseptere at en ung kvinne, gravid i 1. trimester, må oppsøke legen på nabokontoret eller reise inn til byen for å få henvisning til abort - vil man da kunne akseptere at svært syke, lidende, immobiliserte kreftpasienter må reise lange avstander for å finne fram til en lege som er villig til å gi dem dødshjelp? Human-Etisk Forbund uttalte i forbindelse med reservasjonsstriden at «legens holdninger og religion er strengt tatt irrelevant»(Gran, 2014). Jeg tror legers motvilje 
mot å hjelpe lidende mennesker med å få en «verdig død» vil bli betraktet på samme vis.

Det er mulig samfunnet lenge vil respektere legers ønske om ikke å utføre eutanasi, en veldig konkret handling der pasienten bokstavelig talt dør for legens hånd. Derimot er det langt mer usikkert om man vil respektere samvittighetskvaler når det gjelder å forskrive medikamenter til legeassistert selvmord - og enda mindre reservasjon mot å viderehenvise til en villig lege.

I Canada var det, i forbindelse med legaliseringsdebatten i 2015-16, klart at ingen lege skulle kunne tvinges til å utføre dødshjelp. Men straks loven var på plass, begynte presset mot legene - for å utføre dødshjelp, men framfor alt for «effective referral». Det kan virke som et greit kompromiss - at den som ikke selv vil utføre dødshjelpen, hjelper pasienten med å finne fram til en annen som kan tilby tjenesten. Men hvis slik viderehenvisning skal være til praktisk nytte for pasienten, en «effective referral», fordrer det at legen som vegrer seg, henviser til en lege som ikke bare er villig, men som med stor sannsynlighet vil gi den konkrete pasienten dødshjelp. Hvis ikke ville viderehenvisningen bare utgjort en formålsløs strafferunde for pasienten (Horn, 2016b). Men da blir også henvisende lege medskyldig i at pasienten geleides fram mot dødshjelp.

\subsection{Avgrensning}

For mange leger er et hovedargument mot legalisering av dødshjelp avgrensningsproblemet: Gitt at samfunnet ikke ønsker at alle som ber om det, skal få hjelp til å dø. Hvordan skal man da lage regler og praksis som skiller mellom hvem som skal få hjelp til å dø, og hvem som skal nektes denne hjelpen? For leger er dette ikke bare en teoretisk øvelse. Det er en konkret klinisk problemstilling, der svaret i hvert enkelt tilfelle må bli et ja eller et nei - med enorme og irreversible konsekvenser for både pasienten og andre berørte parter.

Det offentlige dødshjelpsordskiftet handler ofte om de klare motsatsene: Den sterkt lidende kreftpasienten på dødens terskel - mot den ulykkelige tenåringsjenta med kjærlighetssorg. Men som lege vet jeg at det ikke er disse tilfellene som vil skape usikkerhet og rom for feil. Det er et 
stort potensial for gråsoner; tvilstilfeller der myndighetenes føringer ikke vil gi noe klart svar. I slike tilfeller vil pasientens videre liv eller død hvile på legens skuldre. Enten legen sier ja til dødshjelp og påtar seg ansvaret for et medmenneskes død, eller han/hun sier nei, slik at pasienten lider videre eller begår et brutalt selvmord, må legen leve videre med ansvaret for beslutningen og konsekvensene den fikk.

I dødshjelpsdebatten er det påfallende hvor lett ikke-leger tar på disse vanskelige avgjørelsene. Det hevdes at leger til stadighet tar vanskelige avgjørelser, beheftet med usikkerhet og store konsekvenser, og at dødshjelp dermed ikke vil innføre noe radikalt nytt i så måte (Moen \& Sterri, 2019). Men krevende avgjørelser under usikkerhet er ikke noe vi leger tar lett på, og de tærer på oss (Robertsen, Helseth, Laake \& Førde, 2019). Dødshjelp skiller seg dessuten fra andre vanskelige avgjørelser leger står i, fordi konsekvensen av legens skjønnsbaserte vurdering er så dramatisk: Man må velge om pasienten skal leve eller dø, og det er legens handling som fører til det ene eller det andre resultatet. Dette skiller seg fra for eksempel beslutningen om behandlingsbegrensning. Der må legen vurdere om videre livsforlengende behandling - slik som krevende og til dels plagsom intensivbehandling, eller cellegiftkurer - er til nytte for pasienten. Pasientens død er ikke det entydige resultatet av legens valg; døden skyldes en naturlig, biologisk prosess der pasienten er døende. Den er ikke målet for legens beslutning, selv om den kan være en følge av den (se også kap. 2).

Utfordringene med å lage en dødshjelpslov som avgrenser når dødshjelp er riktig og galt, på en entydig, rettferdig og forsvarlig måte, diskuteres mer utførlig i kap. 15.

\section{Oppsummering}

Som kliniker med ansvar for alvorlig syke og døende pasienter kan jeg skjønne hvorfor pasienter, pårørende og befolkningen generelt ønsker at dødshjelp skulle vært tillatt. Jeg forstår også at leger kan tenke det samme. Argumentene for at vi burde hatt dødshjelp, er gode - både barmhjertighet og autonomi er viktige verdier som motiverer også oss dødshjelpsmotstandere. Når jeg likevel sier nei, handler det om at motargumentene er så sterke, for meg nærmest uoverkommelige. 
Det er ikke minst krevende for den som skal utføre dødshjelpen - de fleste peker på legen. Det er vi leger som må treffe de vanskelige avgjørelsene, og leve videre med ansvaret for konsekvensene av våre valg. Vi blir plassert i en skvis mellom pasientens behov og hensynet til vår egen integritet og velferd. Vi må kombinere selvmordsforebygging med selvmordsassistanse, uten andre veiledere enn vårt eget skjønn og et tvetydig lovverk. Jeg mener det er urimelig av samfunnet å plassere oss i denne posisjonen - og det er spesielt galt å gi oppgaven til oss leger. Vår rolle er en annen, og den er krevende nok som den er: Vi skal hjelpe svake og lidende pasienter med å holde ut livets siste, vanskelige fase. Da trenger vi det rekkverket et forbud mot dødshjelp utgjør.

\section{Referanser}

American Academy of Neurology. (2014). 2014 Physician-assisted suicide survey. Hentet fra https://download.lww.com/wolterskluwer_vitalstream_com/ PermaLink/WNL/A/WNL_90_9_2018_01_26_RUSSELL_2017795021_SDC2. pdf

Annon, J. S. (1976). The PLISSIT model: A proposed conceptual scheme for the behavioural treatment of sexual problems. J Sex Education and Therapy, 2, 1-15. Hentet fra https://www.tandfonline.com/doi/pdf/10.108o/01614576.1976. 11074483 ? needAccess $=$ true

Barlaup, A. H., Landsverk, Å. E., Myskja, B. K., Supphellen, M. \& Magelssen M. (2019). Acceptable attitudes and the limits of tolerance: Understanding public attitudes to conscientious objection in healthcare. Clinical Ethics, 14(3), 115-121.

Blomkvist, A. W. \& Zadig, P. (2018). Står legeeden i veien for dødshjelp? Tidsskr Nor Legeforen, 138(11). Hentet fra https://tidsskriftet.no/2018/o6/debatt/star-legeedeni-veien-dodshjelp

Craig, A., Cronin, B., Eward, W., Metz, J., Murray, L., Rose, G., Suess, E. \& Vergara, M. E. (2007). Attitudes toward physician-assisted suicide among physicians in Vermont. J Med Ethics 33, 400-403. Hentet fra https://www.ncbi.nlm.nih.gov/ pmc/articles/PMC2598148/pdf/40o.pdf

Emanuel, E. J., Onwuteaka-Philipsen, B. D., Urwin, J. W. \& Cohen, J. (2016). Attitudes and practices of euthanasia and physician-assisted suicide in the United States, Canada, and Europe. JAMA 316, 79-90. Hentet fra https://jamanetwork. com/journals/jama/fullarticle/2532018

Førde, R. \& Aasland, O. G. (2014). Are end-of-life practices in Norway in line with ethics and law? Acta Anaesthesiol Scand, 58(9), 1146-1150. 
Finlay, I. (2009). Dying and choosing. Lancet, 373, 1840-1841. Hentet fra https:// www.thelancet.com/journals/lancet/article/PIISo140-6736(o9)61012-6/fulltext

Gaasø, O. M., Rø, K. I., Bringedal, B. \& Magelssen, M. (2019). Legers holdning til aktiv dødshjelp. Tidsskr Nor Legeforen, 139(1): 31-35. Hentet fra https://tidsskriftet. no/2019/o1/originalartikkel/legers-holdninger-til-aktiv-dodshjelp

Gran, E. (2014, 4. mars). HEF: - Legens religion og holdninger strengt tatt irrelevant. Fri Tanke. Hentet fra https://fritanke.no/hef-legens-religion-og-holdningerstrengt-tatt-irrelevant/19.9349

Holmøy, T., Aarrestad, S., Engstrand, P., Ottesen, S., Syse, A. \& Førde, R. (2009). Avslutning av respiratorbehandling ved amyotrofisk lateral sklerose. Tidsskr Nor Legeforen, 129, 628-631.

Horn, M. A. (2016a, 25. mars). Bør retten til ikke å ta liv inn i grunnloven? Aftenposten. Hentet fra https://www.aftenposten.no/meninger/kronikk/i/qnLom/ Kronikk-Bor-retten-til-a-nekte-a-ta-liv-inn-i-grunnloven-Morten-Horn

Horn, M. A. (2016b, 28. april). Henvist til døden. Verdidebatt. Hentet fra http://www. verdidebatt.no/innlegg/11640152-henvist-til-doden

Horn, M. A. (2018, 18. juli). Slår inn åpne dører. Tidsskr Nor Legeforen. Hentet fra https://tidsskriftet.no/2018/o7/kommentar/slar-inn-apne-dorer

Hytten, K., Aarseth, S. (2015, 5. januar). Leger og dødshjelp. Dagbladet. Hentet fra https://www.dagbladet.no/2015/01/05/kultur/meninger/kronikk/debatt/ dodshjelp/36981383/)

Kelly, B., Handley, T., Kissane, D., Vamos, M. \& Attia, J. (2019). "An indelible mark". The response to participation in euthanasia and physician-assisted suicide among doctors: A review of research findings. Palliat Support Care. Hentet fra https:// www.ncbi.nlm.nih.gov/m/pubmed/31340873/

Kouwenhoven, P. S. C., van Thiel, G. J. M. W., van der Heide, A., Rietjens, J. A. C. \& van Delden, J. J. M. (2019). Developments in euthanasia practice in the Netherlands: Balancing professional responsibility and the patient's autonomy. Eur J Gen Pract, 25, 44-48. Hentet fra https://www.ncbi.nlm.nih.gov/pubmed/30381970

Lindblad, A., Löfmark, R. \& Lynoe, N. (2008). Physician-assisted suicide: A survey of attitudes among Swedish physicians. Scand J Public Health, 36, 720-727. Hentet fra https://www.ncbi.nlm.nih.gov/pubmed/18775835

Magelssen, M. (2016). Når pasienten ønsker å dø (bokanmeldelse). Tidsskr Nor Legeforen 136, 452. Hentet fra https://tidsskriftet.no/2016/o3/anmeldelser/ nar-pasienten-onsker-do

Materstvedt, L. J. (1998, 22. oktober). Dødshjelp og selvbestemmelse. Dagbladet. Hentet fra https://www.dagbladet.no/kultur/dodshjelp-ogselvbestemmelse/65485855

Materstvedt, L. J. (2019). Selvbestemmelse - en hellig ku i det sekulære Vesten. Nytt Norsk Tidsskrift 36, 230-240. 
Moen, O. M. \& Sterri, A. B. (2019). Aktiv dødshjelp. Etikk ved livets slutt. Oslo: Cappelen Damm Akademisk.

NOU 2016: 13. (2016). Samvittighetsfrihet i arbeidslivet. Oslo: Arbeids- og sosialdepartementet. Hentet fra https://www.regjeringen.no/contentassets/ 3f93bdb31a5942fba104512d4a3b8foo/no/pdfs/nou20162016oo13ooodddpdfs.pdf

Roberts, L. W., Roberts, B. B., Warner, T. D., Solomon, Z., Hardee, J. T. \& McCarty, T. (1997). Internal medicine, psychiatry, and emergency medicine residents' views of assisted death practices. Arch Intern Med, 157, 1603-1609. Hentet fra https:// jamanetwork.com/journals/jamainternalmedicine/article-abstract/623610

Robertsen, A., Helseth, E., Laake, J. H. \& Førde, R. (2019). Neurocritical care physicians' doubt about whether to withdraw life-sustaining treatment the first days after devastating brain injury: An interview study. Scand J Trauma, Resusc Emerg Med, 26, 81. Hentet fra https://www.ncbi.nlm.nih.gov/pubmed/31462245 Schjødt, B. (2010, 5. januar). Hjelp til å ville leve. Tidsskrift for norsk psykologforening, 47. Hentet fra https://psykologtidsskriftet.no/debatt/2010/o1/hjelp-til-ville-leve Statens medicinsk-etiska råd. (2017). Dödshjälp. En kunskapssammanställning. Hentet fra http://www.smer.se/rapporter/dodshjalp-en-kunskapssammanstallning/ Stutzki, R., Weber, M., Reiter-Theil, S., Simmen, U., Borasio, G. D. \& Jox, R. J. (2014). Attitudes towards hastened death in ALS: A prospective study of patients and family caregivers. Amyotroph Lateral Scler Frontotemporal Degener, 15, 68-76. van Marwijk, H., Haverkate, I., van Royen, P. \& The, A-M. (2007). Impact of euthanasia on primary care physicians in the Netherlands. Palliat Med, 21, 609-14.

Vigeland, K. (2009, 5. august). Aktiv dødshjelp - en siste utvei. Tidsskrift for norsk psykologforening 46. Hentet fra https://psykologtidsskriftet.no/debatt/2009/o8/ aktiv-dodshjelp-en-siste-utvei

\section{Ordforklaringer}

adgang: tillgång $(\mathrm{S})$, adgang $(\mathrm{D})$

bunnsolid: bärgfast (S), bundsolid (D)

dytte: knuffa (S), skubbe (D)

dårlig: illa (S), dårligt (D)

enten: antingen (S), enten (D)

fastlege: allmänläkare (S), praktiserende læge (D)

fravær: frånvaro $(\mathrm{S})$, fravær $(\mathrm{D})$

følelsesmessig: känslomässig (S), følelsesmæssigt (D)

føler: känner (S), føler (D)

føringer: riktlinjer (S), retningslinjer (D) 
geleide: följa (S), følge (D)

gjenspeile: reflektera (S), afspejle (D)

gå glipp av: missa (S), gå glip af (D)

helsevesenet: sjukvården (S), sundhedsvæsenet (D)

hensikt: avsikt (S), hensigt (D)

kreft: cancer

reservasjon: avstå fra en arbeidsoppgave av samvittighetsgrunner/samvetsskäl

ryggdekning: uppbacking (S), opbakning (D)

samvittighet: samvete (S), samvittighed (D)

samvittighetskvaler: samvetskval (S), samvittighedsnag (D)

sannsynlig: sannolikt (S), sandsynligt (D)

selvmordstruede: självmordsbenägna (S), selvmordstruede (D)

sengepost: sjukhusavdelning (S), sengeafdeling (D)

skjønnsbasert: diskretionär (S), skønsmæssigt (D)

skjøtte: hantera (S), håndtere (D)

skvis: konflikt (S/D)

skyldes: orsakas av (S), forårsages af (D)

spørreundersøkelser, meningsmålinger: opinionsmätningar (S),

spørgeundersøgelser (D)

streve med: sträve med (S), kæmpe med (D)

støtende: stötande (S), uskøn (D)

tiltak: åtgärd (S), tiltag (D)

trekke inn: involvera (S), involvere (D)

trøbbel: besvär (S), problemer (D)

trå feil: handla fäl (S), gøre fejl (D)

tvilstilfeller: tveksamma fall (S), tvivlstilfælder (D)

uutholdelig: outhärdlig (S), uudholdelig (D)

utprøving: experimenterande (S), eksperimentering (D)

yte: tillhandahålla $(S)$, give (D) 


\title{
Kan lindrende behandling fjerne behovet for dødshjelp?
}

\author{
Siri Brelin
}

Sykehuset Østfold

\begin{abstract}
Today's palliative treatment is effective. The challenge is to ensure that all areas of the healthcare sector that meet patients in the last phase of life have the necessary expertise, so that all patient groups who need palliative treatment receive it. In this chapter I will analyse, from the perspective of the palliative care practitioner, how well the healthcare service presently performs this task, describe the phenomenon of unbearable suffering and the treatment called palliative sedation, and argue that good palliative care makes assisted dying superfluous.
\end{abstract}

Keywords: assisted dying, euthanasia, pain, palliative care, palliative sedation, unbearable suffering

Det betyr ikke så meget hvordan man er født, men det har uendelig meget å si hvordan man dør.

-Søren Kierkegaard

Jeg kan vanskelig tenke meg en pasienthistorie som bedre kan beskrive en utfordrende palliasjonssituasjon enn historien om «Linnea». Linnea var en 27 år gammel gift trebarnsmor, og hadde avansert brystkreft med spredning til lunger, lever og skjelett. Skjelettspredningen gjorde at hun hadde ustabile brudd i halsvirvlene, slik at hun til tross for støttende halskrage måtte ligge helt stille i sengen for ikke å risikere plutselig død. Strålebehandling,

$1 \quad$ Før hun døde, ga pasienten sin tillatelse til at historien kunne offentliggjøres. Hennes ektemann samtykket også.

Sitering av denne artikkelen: Brelin, S. (2020). Kan lindrende behandling fjerne behovet for dødshjelp? I M. A. Horn, D. J. H. Kleiven \& M. Magelssen (Red.), Dødshjelp i Norden? Etikk, klinikk og politikk (Kap. 10, s. 193-211). Oslo: Cappelen Damm Akademisk. https://doi.org/10.23865/noasp.96.ch1o.

Lisens: CC BY 4.o. 
hormonbehandling og cellegiftbehandling var forsøkt uten effekt, og man hadde ikke flere medisinske tiltak utover lindring av plager.

Linnea hadde forferdelige smerter i nakken, og sterke, smertestillende medikamenter hadde minimal og kortvarig effekt. Det var kun hvis hun fikk så store doser at hun fikk sove en liten stund, at hun opplevde god lindring. Beroligende medikamenter hadde samme effekt, men hun var ikke lindret uten at bevisstheten hennes ble redusert som en bivirkning av medikamentene. Dette ble også åpenbart for Linnea og hennes mann, og vi samtalte derfor om muligheten for medikamentindusert søvn som lindrende tiltak (lindrende sedering). Med lindrende sedering menes medikamentell reduksjon av bevissthetsnivået for å lindre lidelse som ikke kan avhjelpes på annen måte. Linnea var svært takknemlig for at det fantes en slik mulighet; det hadde hun ikke hørt om tidligere.

Etter flere samtaler, og tverrfaglig enighet på avdelingen, fikk Linnea lindrende sedering med faste avtaler om oppvekking. Når hun våknet etter noen timers søvn, var hun i stand til å bære smertene i et par timer. Hun klarte igjen å ha besøk av barna sine (tre barn under fem år). De klatret opp i sykesengen og satt stille og tegnet eller puslet puslespill så lenge Linnea orket å være våken, fra en halv time til to timer. Når Linnea sa fra at hun ikke orket mer, fikk hun igjen sove, og hun sov hele netter. I de våkne stundene hadde hun og mannen viktige samtaler, og begge sa at dette var svært meningsfull tid for dem. Også resten av Linneas familie var til stede, og gamle familiekonflikter fikk løsninger, til stor lettelse for både Linnea og de øvrige involverte. Hun maktet også å samtale med barna sine om at hun skulle dø, slik at de fikk mulighet til å forberede seg. Etter seks dager med lindrende sedering døde Linnea fredelig, med mannen ved sin side.

\section{Kort om palliasjonens historie, ideologi og organisering i Norge}

Palliasjon kan defineres slik:

Palliasjon er aktiv behandling, pleie og omsorg for pasienter med inkurabel sykdom og kort forventet levetid. Lindring av fysiske smerter er sentralt. Målet 
er best mulig livskvalitet for pasienten og de pårørende. Palliativ behandling og omsorg verken fremskynder døden eller forlenger selve dødsprosessen. (Helsedirektoratet, 2015)

Palliativ medisin er et ungt fag, både i Norden og internasjonalt. Teoribyggingen og den begynnende systematiseringen av faget tilskrives ofte Dame Cicely Saunders, som var sykepleier, sosionom og lege. Symptomrettet - fremfor årsaksrettet - behandling sto sentralt i Saunders' arbeid, sammen med en filosofi om respekt for den døendes ønsker og behov (Saunders, 1964). Autonome avgjørelser omkring egen behandling og hvor omsorg og pleie skulle gis, skulle være førende for hvilke tiltak som ble valgt.

I Norge foregår bare $15 \%$ av dødsfall i hjemmet, mens 50 \% dør i sykehjem og $35 \%$ på sykehus. Med økende kunnskap om at de fleste ønsker å tilbringe så mye tid i hjemmet eller så nær hjemmet som mulig (Gomes, Calanzani, Gysels, Hall \& Higginson, 2013), er det etablert kreftsykepleiernettverk i kommunene og lindrende enheter på kommunale sykehjem. Den spesialiserte lindrende behandlingen er lagt til sykehusene (helseforetakene), og regionssykehusene har ansvar for å koordinere utdanning, forskning og fagutvikling.

Det tilbys spesialisert utdanning i palliasjon for sykepleiere, helsefagarbeidere, prester, sosionomer og fysioterapeuter. For leger foreligger det en nordisk utdanning som - sammen med arbeidserfaring fra godkjent palliativt senter på sykehus og eventuelt sykehjem - gir godkjenning i «kompetanseområde palliativ medisin».

\section{Palliasjon under press}

Palliativ behandling i Norge er under press. Vi har for mange pasienter, for lite kompetent personale og for dårlige lokaler. I befolkningen generelt er det for lite kunnskap om normale dødsprosesser, og «det moderne mennesket» har holdninger til funksjonstap og menneskeverd som etter mitt syn iblant er etisk betenkelige. Men vi har også mange ildsjeler i palliasjonsmiljøet, og mye godt palliativt arbeid gjøres hver dag. 


\section{Økende gap mellom etterspørsel og tilbud}

$\varnothing \mathrm{kt}$ levealder i befolkningen medfører at en større andel er mer utsatt for alvorlig sykdom. Samtidig gjør moderne behandling at man lever lenger med lidelsen. Når tilbud om palliativ behandling skal gis alle med alvorlig, dødelig sykdom, og ikke bare kreftpasienter (NOU 2017:16), er ikke det norske palliasjonstilbudet rustet for dette. Den offentlige utredningen «På liv og død» fra 2017 skisserer gode tiltak for opprusting av fagmiljøet og utdanningskapasiteten. Men slike tiltak krever mye tid. I mellomtiden er den faktiske tiden vi har til anvendelse på hver enkelt palliative pasient, stadig minkende, samtidig som effektivitetskravene øker. Tidsknapphet og palliasjon er uforenlige, fordi det tar tid å dø. Og den tiden man bruker på å dø, er viktig, både for den døende og for de pårørende:

Hvordan mennesker dør, forblir som viktige minner hos dem som lever videre. Både av hensyn til dem og til pasienten, er det vår oppgave å kjenne til hva som forårsaker smerte og plager, og hvordan vi kan behandle disse plagene effektivt. Det som skjer de siste timene før et menneske dør, kan lege mange tidligere sår, eller forbli som uutholdelige erindringer som forhindrer veien gjennom sorg. (Cicely Saunders, sitert i Den norske legeforening, 2001)

Det er i dag 49 kommunale lindrende enheter i Norge, men kompetansen her varierer mye. Ressursknapphet, uegnede lokaler og mangel på kompetent personale gjør dessverre at omsorgen ikke alltid får den ønskede kvaliteten, hvilket jevnlig resulterer i kritiske meningsytringer i media (se for eksempel Hattrem, 2012).

\section{Betydningen av den «ukjente» dødsprosessen}

Døden har vært kalt det siste tabu, og befolkningens kunnskap om normale dødsprosesser er ikke slik den var for hundre år siden. I dag skjer som nevnt de aller fleste dødsfall i institusjon, og avstanden til død og dødsprosess er blitt stor. Det er ikke lenger allment kjent at det å dø kan innebære fysisk svekkelse med økende søvnbehov, behov for sosial og mental isolering, bortfall av evne til - og ønske om - å innta mat, drikke og tabletter, svingende temperatur, forvirring, koma og surklete respirasjon. 
Det er heller ikke allment kjent at denne prosessen for de fleste ikke synes å være uttalt plagsom, men egentlig mer slitsom, forutsatt god symptomlindring og omsorgsfull pleie (Rosland, von Hofacker \& Paulsen, 2006). I en verden hvor sosiale medier, unge «influencere» og reality-show får prege mediene med sine forskjønnede virkelighetsbeskrivelser av hva som er et meningsfullt og verdig liv, er det ikke så underlig at det synes å råde en oppfatning om at ethvert funksjonstap er ensbetydende med uverdig livskvalitet, og at dødsprosessen anses som en krenkelse (Bjørnstad, 2012).

Medias fremstilling av lidelsesfulle dødsprosesser uten en tilgjengelig løsning bidrar til fremmedgjøring og engstelse, og behovet for en kontrollert «quick fix» får rikelig grobunn. Erfaringer fra Belgia viser at behovet for kontroll står sentralt i motivasjonen for eutanasi-forespørsler (Vanden Berghe, Mullie, Desmet \& Huysmans, 2017). Palliasjonens svar er en uglamorøs, men livsviktig virkelighetsbeskrivelse av dødsprosessen som en nær og sorgtung, men viktig og uavvendelig del av fullførelsen av livet.

Under denne prosessen summeres livet opp, betydningsfulle opplevelser deles, kjærlighetsuttrykk intensiveres, og praktiske og økonomiske løsninger kommer på plass. Ofte har den døende et behov for «opprydning i eget bo», konflikter finner sin løsning, og pårørende forlikes. Samtidig legges grunnlaget for sorgprosesser de etterlatte må gjennom. Det er viktig for de pårørende å se at den døende ikke har noen vei tilbake til et friskt liv. I dette ligger det å observere og akseptere funksjonssvikt og kroppens forfall, sårbarhet og omsorgsbehov - oftest alt annet enn glamour.

\section{Hvor effektivt kan vi lindre?}

Palliativ behandling og omsorg tar sikte på å forbedre livskvaliteten til pasienter med uhelbredelig og dødelig sykdom gjennom bedre symptomkontroll, koordinering av omsorg og bedre kommunikasjon mellom fagpersoner, pasient og familie. Jo bedre vi lykkes med lindring på rett nivå, jo mer spares samfunnet for kostnader ved gjentatte innleggelser $\mathrm{i}$ sykehus og bruk av høyteknologisk behandling (Skår et al., 2014). 


\section{I hvilken grad lykkes vi med å forbedre livskvalitet?}

Palliativ medisin er effektiv når det gjelder symptomlindring, livskvalitet og pasient- og pårørendetilfredshet (Oliver, 2018; Holmenlund, 2017; Gaertner et al., 2017; Davis \& Temel, 2015). Tidlig integrering av palliasjon $\mathrm{i}$ pasientforløp ved uhelbredelig og dødelig sykdom ser ut til å øke kvaliteten ytterligere (NOU 2017:16). Den holistiske tilnærmingen favner både pasient og pårørende, og den øker oppmerksomheten om innhold og kvalitet i tilværelsen, inkludert det å få mulighet til å oppholde seg - og få omsorg - på ønsket sted. Ved å gjøre palliative tiltak pasientsentrerte gjennom å bringe behandlingen ut til pasienten, fordobles muligheten for å kunne $\mathrm{d} \varnothing$ i eget hjem (Gomes, Calanzani, Curiale, McCrone \& Higginson, 2013).

Til tross for studier som viser at symptomlindrende, palliativ behandling er effektiv, finnes det pasienter med lidelser som det er vanskelig å lindre tilfredsstillende, både på sykehus og i kommunehelsetjenesten. Det har vært estimert at man med kartlegging og behandling av symptomer oppnår effektiv lindring hos ca. $95 \%$ av alvorlig syke og døende pasienter (Husebø, 2005). Altså vil ca. $5 \%$ ikke bli tilfredsstillende lindret ved konvensjonell palliativ behandling, og kan trenge lindrende sedering. Tallene er ikke hugget i sten, men passer med min erfaring fra Senter for lindrende behandling ved Sykehuset Østfold. Blant våre 65 pasienter som døde inneliggende på avdelingen i 2016, var det tre som fikk lindrende sedering (uoffisielle tall etter opptelling). Dette er altså pasienter som er henvist for spesialisert palliativ behandling. Den generelle palliasjonen utføres ved alle de somatiske avdelingene, men der gjøres ved vårt sykehus i regelen $i k k e$ lindrende sedering.

En norsk studie viser at døende sykehjemspasienter hadde god effekt av den medikamentelle behandlingen som ble gitt ved livets slutt, men en overraskende høy andel hadde fortsatt symptomer som tungpustethet og smerter på sin dødsdag. Forfatterne konkluderer med at dette snarere skyldes manglende behandlingskompetanse blant sykehjemspersonalet enn sviktende effekt av medikamentene (Sandvik, Selbæk, Bergh, Aarsland \& Husebø, 2016). Men vi har også noen få pasienter hvor tilfredsstillende symptomlindring er svært komplisert å oppnå, tross intensiv innsats fra høyt kvalifisert personell på spesialenheter for palliativ medisin. Oftest dreier dette seg om kompliserte, sammensatte smertetilstander. 
Smerte er definert som en ubehagelig sensorisk og emosjonell opplevelse som følge av faktisk eller potensiell vevsødeleggelse. Smerten er alltid subjektiv. Den er et sammensatt fenomen som påvirkes av fysiske, psykiske, sosiale, kulturelle og åndelige/eksistensielle forhold. Begrepet «total pain» brukes ofte i palliasjon for å beskrive denne kompleksiteten (Helsedirektoratet, 2015).

Slik «total pain» innebærer at selve lidelsen ved å være syk, oppleve dyptgripende tap, ha mistet funksjoner og måtte innse at livets slutt nærmer seg, kan oppleves som en fysisk, gjennomgripende smerte. Sammen med den fysiske smerten konkret vevsødeleggelse medfører, vil en slik eksistensiell smerte kunne være vanskelig å håndtere effektivt, og for pasienten vil totaliteten kunne oppleves som uutholdelig. Uutholdelig lidelse er en utfordrende situasjon for både pasienten, pårørende og personalet.

\section{Uutholdelig lidelse}

\section{Pasienter med uutholdelig lidelse}

Lidelse har vært definert som en subjektiv, ikke målbar og vanskelig diagnostiserbar «tilstand av nød som oppstår når personens intakthet eller integritet er truet eller forstyrret» (Cassell, 1999). Det eksisterer ingen internasjonal konsensus om begrepet uutholdelig lidelse. Det har en individuell betydning, og kan ikke generaliseres. Uutholdelig lidelse kan for eksempel innebære sterke smerter, ensomhet, angst, tap av kroppsfunksjoner, det å holdes kunstig i live, at byrden overstiger håndteringsevnen eller tap av verdighet (Gootjes, Zuurmond \& Perez, 2010). Her vil begrepet forstås som lidelse som pasienten $i$ sum opplever som ikke til å holde ut eller leve med.

På samme måte som lidelse er en subjektiv opplevelse som varierer fra individ til individ, fra situasjon til situasjon, og med stadig nytt innhold, vil også opplevelsen av livskvalitet og verdighet variere. En studie har vist at pasienter med kort forventet levetid assosierte økende avhengighet av andres hjelp med en følelse av tapt anseelse og mindre respekt fra omgivelsene. Videre assosierte pasientene verdighet med opplevd respekt fra andre (Chochinov et al., 2002). 
Tapte funksjoner og økt hjelpebehov vil altså kunne medføre en opplevelse av verdighetstap som truer integritet og forsterker eksistensiell lidelse. I en annen studie fremgikk det at fysisk smerte var en viktig medvirkende årsak til at pasienter søkte om dødshjelp, men det var først når denne ble kombinert med psykososial og eksistensiell lidelse, at smerten ble til uutholdelig lidelse (Dees, Vernooij-Dassen, Dekkers, Vissers \& van Weel, 2011).

Noen sykdomsrelaterte faktorer kan fremholdes som oftere knyttet til uutholdelig lidelse. Symptomer der det ikke finnes noen behandling som vil kunne gi tilfredsstillende lindring innenfor en rimelig tidsramme, uten å gi uakseptable bivirkninger og/eller sykelighet, kalles ofte refraktoer lidelse (de Graeff \& Dean, 2007). Refraktære tilfeller av smerte knyttet til skade på nerver eller skjelett, tungpustethet med kvelningsopplevelse og utmattende pustearbeid, overmannende angsttilstander, og særlig mutilerende (hode-hals-området) og illeluktende tumorvekst (ondartede sår, anale/genitale fistler) er tilstander jeg i mitt arbeid av og til ser ligge til grunn for lidelse som pasienter beskriver som uutholdelig. Det som kjennetegner disse situasjonene, er altså kombinasjoner av smerter, angst, hjelpebehov og opplevd verdighetstap.

\section{Pårørendes opplevelse av uutholdelig lidelse}

Naturlig nok kan det å være vitne til fysisk, psykososial og åndelig lidelse i livets sluttfase ha stor innvirkning på de pårørende. Det kan forstyrre sorgprosessen og føre til sykdom (Braun, Mikulincer \& Rydall, 2007; Hebert, Arnold \& Schulz, 2007). Flere studier har påvist økt helserisiko hos pårørende som har omsorg for alvorlig syke og døende (Schulz \& Beach, 1999; Mausbach, Patterson, Rabinowitz, Grant \& Schulz, 2007; Siegel, Karus, Raveis, Christ \& Mesagno, 1996). Mange familier unngår dessverre diskusjoner som er smertefulle og følelsesmessig tunge, men som er sentrale for å kunne fatte riktige beslutninger og for å kunne forsone seg med situasjonen (Sutton, 2010). På den annen side opplever også mange pårørende til alvorlig syke og døende pasienter både personlig vekst og tilfredsstillelse ved å ha omsorg for sine kjære (Henriksson, Carlander \& Arestedt, 2015). Det er påvist at palliativ omsorg forbedrer de pårørendes tilfredshet, og at den bedrer kommunikasjon og kunnskap 
om livets siste fase, noe som er sentralt for deres opplevelse og mestring. Helst bør palliasjonen starte kort tid etter at en alvorlig og livstruende sykdom er oppdaget (Hearn \& Higginson, 1998; McDonald et al., 2017), aller helst slik den nye og integrerte modellen for palliasjon er beskrevet i NOU 2017:16, der palliasjonen starter tidlig i forløpet, og vender tilbake med ulik intensitet etter hvert som behovet tilsier det, eller ved viktige milepæler.

\section{Uutholdelig lidelse og lindrende sedering}

I eksepsjonelle tilfeller, hvor ingen annen tilnærming har tilfredsstillende effekt, hender det at pasienten tilbys lindrende sedering. Dette er en behandlingsform hvor man gjennom reduksjon av bevisstheten, til en lett søvnliknende tilstand, oppnår lindring og ro (Førde, Kongsgaard \& Aasland, 2006; Førde et al., 2015). Behandlingen skal sørge for at ingen skal måtte dø i uutholdelig lidelse. Lindrende sedering brukes fortrinnsvis i tilfeller hvor lidelsen utgjøres av en stor fysisk komponent, men også noen ganger der psykisk og eksistensiell lidelse dominerer (Anquinet et al., 2014).

Lindrende sedering er en godt dokumentert og allment akseptert behandlingsmetode ved uutholdelig, behandlingsrefraktær lidelse i livets siste fase (World Medical Association, 2011). Etter den såkalte Bærums-saken ved årtusenskiftet (Laake \& Kvåle, 200o; Ottesen, 2002), hvor en lege ble anklaget for å ha utført dødshjelp i forbindelse med bruk av lindrende sedering, orienterte Statens helsetilsyn i juli 2000 landets sykehus om krav for forsvarlig gjennomføring av lindrende sedering (Statens helsetilsyn, 2000). I 2001 publiserte Legeforeningen «Retningslinjer for lindrende sedering til døende», med oversikt over juridiske, etiske og medisinske krav til forsvarlig utførelse av denne typen behandling. I 2014 ble retningslinjene revidert, og navnet endret til «Retningslinjer for lindrende sedering $i$ livets sluttfase» (min utheving; Førde et al., 2015). De reviderte retningslinjene åpnet for anvendelse av metoden ikke kun i terminalfasen, men også ved dager til ukers forventet gjenstående levetid.

Hvor utbredt lindrende sedering er i Norge, har det ikke vært forsket på siden 2004, og bruken registreres ikke systematisk. Legers holdning til og kompetanse i metoden er også ukjent. Spørsmålet om hvorvidt leger frykter metoden etter Bærums-saken, og derfor ikke tilbyr den, har vært 
luftet, og dermed også muligheten for at pasienter må lide unødig (Materstvedt, Ottesen, von Hofacker \& Syse, 2019). Jeg kommer tilbake til etiske betraktninger omkring lindrende sedering.

\section{Uutholdelig lidelse og ønske om dødshjelp}

Uutholdelig lidelse er et sentralt kriterium for innvilgelse av dødshjelp i flere land der dette er legalisert (se også kap. 13). Det er viktig å holde helt klart at lidelse ikke er synonymt med smerte. Eksempler på dette er at fødsler vanligvis anses som svært smertefulle, men sjelden betegnes som lidelse, mens en halvsidig lammelse etter hjerneslag kan tenkes å innebære stor lidelse, selv uten fysisk smerte. I en studie fra Oregon undersøkte man hva pårørende til 83 personer som hadde bedt om dødshjelp, mente var hovedårsaker til forespørselen. Alle mente at de viktigste grunnene var ønsker om å kontrollere omstendighetene rundt døden og få dø hjemme, bekymringer om fremtidig tap av verdighet og avhengighet av andres hjelp, samt tap av livskvalitet og selvhjulpenhet. Ingen av de pårørende oppga fysiske symptomer som viktigste årsak til anmodningen. Bekymringer om fremtidige plager var generelt viktigere grunner enn symptomer på tidspunktet for forespørselen (Ganzini, Goy \& Dobscha, 2007). Dette stemmer overens med den offisielle statistikken, der pasientenes egne begrunnelser for å ønske dødshjelp er kartlagt: Uutholdelige smerter er ikke blant de hyppigste begrunnelsene (Oregon Health Authority, 2019; se også kap. 14). En norsk studie fra 2005 beskriver derimot nettopp redselen for fremtidig smerte som medvirkende til ønsket om dødshjelp. Samtidig beskrives pasientens ønske om å dø ofte som fluktuerende, og snarere enn å være et genuint dødsønske fremstår det heller som en fremtidig «løsning» dersom symptomlindringen skulle svikte, livskvaliteten bli uutholdelig eller håpløsheten bli overveldende (Johansen, Hølen, Kaasa, Loge \& Materstvedt, 2005).

\section{Etiske spørsmål ved lindrende sedering}

I det følgende vil jeg se nærmere på lindrende sedering, hvorvidt dette fremskynder døden, og om det dermed foreligger en «gråsone» i palliativ medisin. 


\section{Lindrende sedering som en løsning ved uløst lidelse: kriterier, beslutninger og praktisk gjennomføring}

Palliativ medisin vil fremholde lindrende sedering som en løsning ved uløst, uutholdelig lidelse i livets sluttfase, hvor all annen behandling anses som nytteløs. I vurderingen ligger kriteriet om at ingen medisinske, omsorgsmessige eller psykologiske tilnærminger har kunnet bedre lidelsen tilfredsstillende. Ressurs- eller kompetansemangel må ikke ligge til grunn for at behandlingen ikke er tilfredsstillende. Lindrende sedering er altså en slags siste utvei i tilfeller der andre forsøk på å lindre pasientens plager har vært mislykket.

De norske retningslinjene er tydelige på hva som ikke er lindrende sedering: «Retningslinjene omfatter ikke symptomatisk behandling som er del av ordinær praksis, slik som behandling av angst og uro, dyspné og smerter, der sedasjon er en del av behandlingen.» Det vil si at akutt og tidsbegrenset sedering for plutselig oppstått smerte, under sårstell, og ved respirator- eller kirurgisk behandling, ikke er lindrende sedering. Heller ikke døsighet eller redusert bevissthetsnivå som oppstår ved symptomatisk behandling med beroligende og smertestillende midler, er lindrende sedering. Slik behandling er etablert medisinsk praksis og etisk uproblematisk. Det er bare dyp og langvarig sedering, som oftest frem til døden, som krever etiske retningslinjer, siden dette er spesielt krevende og invasivt (Førde et al., 2015).

Formålet med retningslinjene er «å bidra til at pasienter med behandlingsrefraktære plager får tilstrekkelig lindring samtidig som det tilstrebes at sederingen ikke framskynder døden». Beslutningen om lindrende sedering tas i samvalg mellom pasient, pårørende og ansvarlig lege etter tverrfaglig vurdering og refleksjon.

Det benyttes vanligvis morfinliknende medikamenter (opioider) og beroligende medikamenter, og i noen tilfeller narkosemidler. Pasienten skal observeres tilstrekkelig, slik at helsepersonalet kan kontrollere at respirasjonen ikke blir påvirket, og at bevissthetsreduksjonen ikke er dypere enn at plagene besørges lindret, slik at behandlingen ikke fremskynder døden. Likeledes ivaretas væsketilførsel dersom pasienten hadde slik tilførsel, eller drakk selv, før sederingen ble initiert. 
I forbindelse med etableringen av retningslinjene uttalte Rådet for legeetikk at

hos en døende pasient med svake og ustabile funksjoner i vitale organsystemer, vil også mulige bivirkninger av selv en forsiktig titrert lindrende sedering kunne inntreffe lettere. Dette gjelder tap av frie luftveier, hemming av åndedrett og blodsirkulasjon. Dette vil kunne påskynde dødsprosessen. (Rådet for legeetikk, 2001)

Imidlertid foreligger det nå studier som ikke viser noen fremskynding av døden ved bruk av lindrende sedering (Maltoni et al., 2009). Man kan ikke utelukke at lindrende sedering kan bidra til å fremskynde døden i enkelttilfeller, slik all medisinsk behandling innebærer risiko for utilsiktede komplikasjoner. Behandlingen er allikevel allment akseptert, fordi risikoen for komplikasjoner er liten og muligheten for ønsket effekt, nemlig lindring, er stor. Sedering gjør at pasienten blir bevisstløs og mister muligheten til å kommunisere. Til tross for dette anses sedering som det minste ondet når alternativet er å la pasienten fortsette å lide. Til mine pasienter og deres pårørende sier jeg i slike situasjoner at vi tilstreber lindring uten at dødsprosessen i seg selv påvirkes, men at vi ikke sikkert kan utelukke at døden fremskyndes. Jeg har til gode å treffe pasienter eller pårørende som ikke aksepterer en hypotetisk risiko for fremskynding av døden for å oppnå frihet fra uutholdelig lidelse.

\section{«Gråsone» i palliativ medisin?}

Noen tilhengere av dødshjelp hevder at det finnes en "gråsone» hvor det under dekke av palliasjon foregår mye skjult dødshjelp i Norge (se for eksempel Skogman, 2009; Ofstad, 2006). Slik skjult dødshjelp ville innebære at man uten å følge prosedyrer gir økende doser opioider og beroligende midler som ikke er tilpasset den lidelsen som skal lindres, og dermed forvolder pasientens død. Med andre ord fortsetter man å gi opioiddoser selv der pasienten allerede er godt lindret, altså en intendert overdosering, hvilket til slutt kan gi respirasjonsstans. Det foreligger ikke evidens for at denne antakelsen om mye skjult dødshjelp er korrekt, snarere det motsatte (se kap. 3). Det er mulig at bakgrunnen for påstander om 
mørketall når det gjelder dødshjelp i Norge, skyldes forvirring omkring dødshjelp og sammenblanding med behandlingsbegrensning (se kap. 2).

\section{Palliativ medisin og dødshjelp internasjonalt}

Fagmiljøene innenfor palliativ behandling, også her i Norge, tar ofte sterk avstand fra dødshjelp. I land hvor dødshjelp er tillatt, har befolkningen raskt kommet til å betrakte dødshjelp som et vanlig helsetilbud, om ikke som en ordinær pasientrettighet (Vanden Berghe, Mullie, Desmet \& Huysmans, 2017; se også kap. 13). De palliative fagmiljøene i land hvor dødshjelp er legalisert, har ikke respondert likt på anmodningen om integrering av dødshjelp i det eksisterende palliasjonstilbudet. I Belgia har fagmiljøet vært pådriver for at dødshjelp skulle integreres i det palliative tilbudet (Bernheim, Distelmans, Mullie \& Ashby, 2014; Dierickx, Deliens, Cohen \& Chambaere, 2018). I Canada, derimot, har fagmiljøet gått eksplisitt inn for et tydelig skille mellom palliasjon og dødshjelp. Dette understrekes i et dekret fra Canadian Society for Palliative Care Physicians (CSPCP) fra mai 2019. Dekretet vektlegger at palliasjon har som formål å lindre lidelse - ikke ta liv. CSPCP viser til at en forespørsel om dødshjelp kan skjule lidelse som ofte kan lindres ved god palliasjon, samt at ingen pasient må få utført dødshjelp som et resultat av mangelfull palliasjon. Henvisning til dødshjelp skal være pasientinitiert, ikke legeinitiert. Slik ønsker man å unngå utilbørlig press på pasienten fra legen. Pasienten må selv initiere samtalen, og etterspørre informasjon om dødshjelp. Dette indikerer at legene ikke mener at dødshjelp er en naturlig del av palliativmedisinen (Baxter \& Herx, 2019).

\section{Gjør palliativ behandling dødshjelp overflødig?}

Jeg har i dette kapittelet søkt å vise at palliasjonen rår over muligheter for lindring som ikke alltid eliminerer lidelsen fullstendig, men som reduserer den til et nivå hvor livet fortsatt har kvalitet, mening og innhold. Det er dette jeg daglig ser i mitt arbeid som "palliatør». Vi lindrer, trøster og pleier, og «kommer i havn» med smerter, åndenød, angst, 
depresjon, søvnløshet, familiekonflikter, sorg og forsoning. «Å komme i havn» betyr her at den som er døende, klarer å fullføre livet sitt med verdighet og ro, utveksle minner og motta kjærlighet helt inn i de siste dager og timer. Det betyr ikke at man er fullstendig symptomfri. På en skala fra null til ti, hvor null er ingen lidelse og ti er den verst tenkelige lidelse, tilstreber vi at lidelsen for hvert symptom ikke skal overstige 2-3. På dette nivåt vil ikke symptomer virke forstyrrende på konsentrasjon og tankevirksomhet, og pasienten kan klare å holde korte samtaler og uttrykke ønsker helt til søvn og bevisstløshet inntrer naturlig. I noen svært få tilfeller, anslagsvis to til tre hvert år i Østfold fylke, der jeg jobber (ca. 300 ooo innbyggere), kommer vi ikke i havn uten å gi pasienten lindrende sedering. I disse tilfellene er pasienten svært takknemlig for å kunne velge en slik løsning, og pårørende er svært fornøyd med den rolige stemningen og muligheten til å sitte i fred med den døende som sover lett, uten plager.

Mulighetene for «å komme i havn» med palliasjon er faglig sett meget gode. Hvis utgangspunktet er at dødshjelp må tilbys for pasienter som lider uutholdelig ved livets slutt, kan det dermed hevdes at lindrende behandling fjerner behovet for dødshjelp. Å argumentere for dødshjelp ved å vise til utålelig smerte, har lite hold i virkeligheten, slik jeg som palliatør ser den. Hvorvidt lidelse på grunn av engstelse for tap av autonomi og verdighet har mer tyngde som et slikt argument, dreier seg etter mitt skjønn om hvorledes vi som medmennesker og samfunn forholder oss til sykdom og død, og det medfølgende, naturlige behovet for hjelp (se også kap. 5-6). Det som bekymrer meg, er at palliasjonen i Norge er under press, slik at vi ikke klarer å møte alle som trenger det med et like godt tilbud. Vi ønsker å kunne tilby pasientene like god palliasjon i alle deler av landet og på alle helsetjenestenivåer, men det fordrer både kompetanseheving og ikke minst oppgradering av lokaliteter i de kommunale palliative enhetene, slik at de faktisk oppfyller normert standard (Helsedirektoratet, 2015). Enhetene er allerede etablert - vi trenger politisk innsikt og vedtak om å gjøre dem til vakre og verdige steder å dø, med et kompetent og trygt personale. Jeg tror på et helsevesen og samfunn der det å være døende ikke i seg selv er uverdig, ei heller å ha demens, eller være ensom, inkontinent, sårbar, redd eller lei seg. Det er heller ikke 
uverdig å «være til bry». Det er måten vi som samfunn og enkeltpersoner møter den døende på, som eventuelt skaper uverdighetsfølelse. Det må være velferdssamfunnets plikt å sørge for at det å være døende, er en verdig prosess. Diskrepansen mellom palliativmedisinens muligheter til lindring og den målte lidelsen i kommunehelsetjenesten (Sandvik et al., 2016) viser tydelig at det er behov for utbedring, utbygging og kompetanseheving.

You matter because you are you, and you matter to the end of your life.

We will do all we can not only to help you die peacefully,

but also to live until you die.

-Cicely Saunders

\section{Referanser}

Anquinet, L., Rietjens, J., van der Heide, A., Bruinsma, S., Janssens, R., Deliens, L., ... Seymour, J. (2014). Physicians' experiences and perspectives regarding the use of continuous sedation until death for cancer patients in the context of psychological and existential suffering. Psychooncology, 23(5), 539-46.

Baxter, S., \& Herx, L. (2019, 27. november). Joint call to action. Hentet fra https:// www.chpca.net/chpcacspcp

Bernheim, J., Distelmans, W., Mullie, A. \& Ashby, M. A. (2014). Questions and answers on the Belgian model of integral end-of-life care: Experiment? Prototype? Journal of Bioethical Inquiry, 11, 507-529.

Bjørnstad, K. (2012, 11. januar). En fars død. Hentet fra https://www.aftenposten.no/ meninger/kronikk/i/Wb5kQ/En-fars-dod

Braun, M., Mikulincer, M., Rydall, A., Walsh, A. \& Rodin, G. (2007). Hidden morbidity in cancer: Spouse caregivers. J Clin Oncol, 25(30), 4829-4834.

Canadian Society of Palliative Care Physicians. (2019, 17. mai). Key messages: Palliative care and Medical Assistance in Dying. Hentet fra https://www.cspcp.ca/ updated-key-messages-palliative-care-and-medical-assistance-in-dying-maid/

Cassell, E. (1999). Diagnosing suffering: A perspective. Annals of Internal Medicine, 131(7), 531-534.

Chochinov, H., Hack, T., Hassard, T., Kristjanson, L., McClement, S., \& Harlos, M. (2002). Dignity in the terminally ill: A cross-sectional, cohort study. Lancet, 360(9350), 2026-30.

Davis, M., \& Temel, J. (2015). A review of the trials which examine early integration of outpatient and home palliative care for patients with serious illnesses. Ann Palliat Med, 4(3), 99-121. 
de Graeff, A., \& Dean, M. (2007). Palliative sedation therapy in the last weeks of life: A literature review and recommendations for standards. J Palliat Med, 10, 67-85. Dees, M., Vernooij-Dassen, M., Dekkers, W., Vissers, K., \& van Weel, C. (2011). 'Unbearable suffering': A qualitative study on the perspectives of patients who request assistance in dying. Journal of Medical Ethics, 37(12), 727-734.

Den norske legeforening. (2001). Når du blir gammel og ingen vil ha deg. Kap. 6 Et liv med verdighet til det siste. Hentet fra https://legeforeningen.no/Emner/ Andre-emner/Publikasjoner/Statusrapporter/statusrapport-om-situasjonen-ihelsetjenesten-nar-du-blir-gammel-og-ingen-vil-ha-deg/kapittel-6-et-liv-medverdighet-til-det-siste1/

Dierickx, S., Deliens, L., Cohen, J., \& Chambaere, K. (2018). Involvement of palliative care in euthanasia practice in a context of legalized euthanasia: A population-based mortality follow-back study. Palliative Medicine, 32(1), 114-122.

Førde, R., Kongsgaard, U. \& Aasland, O. G. (2006). Lindrende sedering til døende. Tidsskr nor Logeforen, 126, 471-474.

Førde, R., Materstvedt, L. J., Markestad, T., Kongsgaard, U. E., von Hofacker, S., Brelin, S., Ore, S. \& Laudal, M. (2015). Lindrende sedering i livets sluttfase reviderte retningslinjer. Tidsskr nor legeforen, 135, 220-221.

Førde, R., Aasland, O. \& Steen, P. (2002). Medical end-of-life decisions in Norway. Resuscitation, 55(3), 235-40.

Førde, R. \& Aasland, O. (2014). Are end-of-life practices in Norway in line with ethics and law? Acta Anaesthesiol Scand, 58(9), 1146-50.

Gaertner, J., Siemens, W., Meerpohl, J., Antes, G., Meffert, C., Xander, C., ... Becker, G. (2017). Effect of specialist palliative care services on quality of life in adults with advanced incurable illness in hospital, hospice, or community settings. BMJ, 357, j2925.

Ganzini, L., Goy, E. R. \& Dobscha, S. K. (2007). Why Oregon patients request assisted death: Family members' views. J Gen Intern Med, 23(2), 154-157.

Gomes, B, Calanzani, N., Gysels, M., Hall, S. \& Higginson, I. J. (2013). Heterogeneity and changes in preferences for dying at home: A systematic review. BMC Palliat Care, 12:7.

Gomes, B., Calanzani, N., Curiale, V., McCrone, P. \& Higginson, I. (2013). Effectiveness and cost-effectiveness of home palliative care services for adults with advanced illness and their caregivers. Cochrane Database Syst Rev, CDoo776o.

Gootjes, J., Zuurmond, W. \& Perez, R. (2010). Unbearable Suffering. Defining a concept with undefined parameters. European Oncology Nursing Society Newsletter, Autumn 2010, 28-30. Hentet fra https://www.cancernurse.eu/ documents/newsletter/2010autumn/EONSNewsletter2010AutumnPage28.pdf

Hattrem, E. (2012, 30. januar). Sykehjemmet torturerte henne inn i døden. Dagbladet. 
Hearn, J. \& Higginson, I. (1998). Do specialist palliative care teams improve outcomes for cancer patients? A systematic literature review. Palliat Med, 317-332.

Hebert, R., Arnold, R. \& Schulz, R. (2007). Improving well-being in caregivers of terminally ill patients. Making the case for patient suffering as a focus for intervention research. J Pain Symptom Manage, 34(5), 539-546.

Helsedirektoratet. (2015). Nasjonalt handlingsprogram med retningslinjer for palliasjon i kreftomsorgen. Hentet fra: https://www.helsedirektoratet.no/ retningslinjer/palliasjon-i-kreftomsorgen-handlingsprogram

Helsetilsynet. (2006). Kartlegging av bruk av lindrende sedering til døende. Rapport fra Helsetilsynet 6/2006. Hentet fra https://www.helsetilsynet.no/globalassets/ opplastinger/Publikasjoner/rapporter2006/helsetilsynetrapport6_2006.pdf/

Henriksson, A., Carlander, I. \& Arestedt, K. (2015). Factors associated with feelings of reward during ongoing family palliative caregiving. Palliat Support Care, 13(3), 505-512.

Holmenlund, K. (2017). Specialized palliative care in advanced cancer: What is the efficacy? A systematic review. Palliat Support Care, 15(6), 724-740.

Husebø, S. (2005). Kan alle forvente 'en god død'? I H. Herrestad \& L. Mehlum (Red.), Uutholdelige liv - om selvmord, eutanasi og behandling av de døde (s. 154-172). Oslo: Gyldendal.

Johansen, S., Hølen, J. C., Kaasa, S., Loge, J. H. \& Materstvedt, L. J. (2005). Attitudes towards, and wishes for, euthanasia in advanced cancer patients at a palliative medicine unit. Palliative medicine, 19(6), 454-460.

Laake, J. \& Kvåle, R. (2000, 2. juni). Lærer vi av Bærum-saka? Aftenposten.

Löfmark, R., Nilstun, T., Cartwright, C., Fischer, S., van der Heide, A., Mortier, F., ... Onwuteaka-Philipsen, B. (2008). Physicians' experience with end-of-life decisionmaking. Survey in 6 European countries and Australia. BMC Medicine, 6(4).

Maltoni, M., Pittureri, C., Scarpi, E., Piccinini, L., Martini, F., Turci, P., ... Amadori, D. (2009,). Palliative sedation therapy does not hasten death: Results from a prospective multicenter study. Ann Oncol., 20(7), 1163-9.

Materstvedt, L., Ottesen, S., von Hofacker, S. \& Syse, A. (2019, 29. januar). Unødvendig lidelse kan unngås ved livets slutt. Dagens Medisin.

Mausbach, B., Patterson, T., Rabinowitz, Y., Grant, I. \& Schulz, R. (2007). Depression and distress predict time to cardiovascular disease in dementia caregivers. Health Psychol., 26(5), 539-44.

McDonald, J., Swami, N., Hannon, B., Lo, C., Pope, A., Oza, A., ... Zimmermann, C. (2017). Impact of early palliative care on caregivers of patients with advanced cancer: Cluster randomised trial. Annals of Oncology, 28(1), 163-168.

Miccinesi, G., Rietjens, J., Deliens, L., Paci, E., Bosshard, G., Nilstun, T., ... van der Wal, G. (2006). Continuous deep sedation: Physicians' experiences in six European countries. J Pain Symptom Manage, 31(2), 122-9. 
NOU 2017: 16. (2017). På liv og død. Hentet fra https://www.regjeringen.no/ contentassets/995cf4e2d4594094b48551eb381c533e/nou-2017-16-pa-liv-ogdod.pdf

Ofstad, J. (2006). Den siste hjelper. Oslo: Arneberg forlag.

Oliver, D. (2018). Improving patient outcome through palliative care integration in other specialized health care services. Ann Palliat Med, 7(Suppl 3), S219-S23o.

Oregon Health Authority (2019). Death with dignity annual reports. Oregon's Death with Dignity Act - 2018. Hentet fra https://www.oregon.gov/oha/ PH/PROVIDERPARTNERRESOURCES/EVALUATIONRESEARCH/ DEATHWITHDIGNITYACT/Documents/year21.pdf

Ottesen, S. (2002). Må jeg dø i smerte? Pasientens lidelse - legens valg. Oslo: Aschehoug \& co.

Rådet for legeetikk. (2001). Retningslinjer for lindrende sedering til døende.

Rosland, J. H., von Hofacker, S. \& Paulsen, Ø. (2006). Den døende pasient. Tidsskr nor Legeforen, 126: 467-70.

Sandvik, R. K., Selbæk, G., Bergh, S., Aarsland, D., \& Husebø, B. S. (2016). Signs of imminent dying and change in symptom intensity during pharmacological treatment in dying nursing home patients: A prospective trajectory study. J Am Med Dir Assoc., 17(9), 821-7.

Saunders, C. (1964). The symptomatic treatment of incurable malignant disease. Prescr J, 4: 68-73.

Schulz, R. \& Beach, S. (1999). Caregiving as a risk factor for mortality: The caregiver health effects study. JAMA, 282(23), 2215-2219.

Siegel, K., Karus, D., Raveis, V., Christ, G. \& Mesagno, F. (1996). Depressive distress among the spouses of terminally ill cancer patients. Cancer Pract., 4(1), 25-30.

Skår, A., Juvet, L., Smedslund, G., Bahus, M., Pedersen, R. \& Fure, B. (2014). Livets sluttfase - om å finne passende behandlingsnivå og behandlingsintensitet for alvorlig syke og døende. Rapport fra Kunnskapssenteret nr. 18-2014. Oslo: Nasjonalt kunnskapssenter for helsetjenesten.

Skogman, A. (2009, 29. mai). Aktiv dødshjelp og Frp. Hentet fra https://www.nordlys. no/ytring/aktiv-dodshjelp-og-frp/s/1-79-43660o8

Statens Helsetilsyn. (2000). Sedasjon i terminal fase ved kreftsykdom. Hentet fra https://www.helsetilsynet.no/historisk-arkiv/brev-og-horingsuttalelser/brevhoeringsuttalelser-2002-tidligere/Sedasjon-terminal-fase-kreftsykdom/

Sutton, L. (2010). We can't let crucial end of life choices be impaired by silence. Nurs Times, 106(10), 24.

Vanden Berghe, P., Mullie, A., Desmet, M., \& Huysmans, G. (2017). Assisted dying: The current situation in flanders: Euthanasia embedded in palliative care. I D. A. Jones, C. Gastmans, C. MacKellar (Red.), Euthanasia and assisted suicide. Lessons from Belgium (s. 65-66). Cambridge: Cambridge University Press. 
World Medical Association. (2011). WMA declaration on end-of-life medical care.

Hentet fra https://www.wma.net/policies-post/wma-declaration-on-end-of-lifemedical-care/

\section{Ordforklaringer}

behandlingsrefraktær: som inte/ikke lar sig behandla/behandle (S/D)

håndteringsevne: hanteringsförmåga $(\mathrm{S})$, håndteringskapacitet $(\mathrm{D})$

jeg har til gode: jag har ennu inte (S)

lei seg: ledsen (S), mismodig (D)

surklete: skramlande (S), raslende (D)

sårstell: sårvård (S), sårpleje (D)

tiltak: åtgärder (S), tiltag (D)

titrert: anpassat (S), titreret (D) 



\title{
Psykiatri och dödshjälp
}

\section{Sven Román}

Specialist i barn- och ungdomspsykiatri och överläkare

\begin{abstract}
Supporters of legalisation of assisted dying often assume that people who want such assistance on the one hand, and "traditional" suicidal patients with mental illnesses on the other, are two completely distinct groups. An important purpose of this chapter is to show that it is not that simple. Psychiatry sees a death wish as a symptom of a psychiatric condition or a life crisis. With the help of psychotherapy and sometimes medication as a supplement, patients usually regain their appetite for life. There is evidence that many people who want assisted dying also suffer from mental illness in a broad sense. From a psychiatric perspective, they should receive support and psychiatric treatment, with the goal of helping them experience meaning and quality of life. The chapter's author is a child and adolescent psychiatrist, and the chapter is based on published research, contributions to public debate and own experience from clinical work with patients.
\end{abstract}

Keywords: assisted dying, euthanasia, mental illness, psychiatry, suicide

\section{Vad psykiatrin kan göra i mötet med patienter som önskar dödshjälp}

\subsection{Psykiatrins kärna, förhållningssättet till suicidalitet}

Psykiatern möter dagligen suicidala patienter. De kan känna livsleda, ha en önskan om att dö, ha tänkt ut och planerat hur de ska ta livet av sig eller ha gjort ett eller flera suicidförsök. Några självmordsnära patienter gör aldrig något suicidförsök, andra gör ett eller flera som de överlever med eller utan fysiska men, några fullbordar ett suicid efter ett eller flera suicidförsök.

I psykiatrin utgår vi ifrån att suicidala patienter tappat livslusten på grund av psykisk och social ohälsa. Vår erfarenhet är att de i sitt allvarliga tillstånd

Sitering av denne artikkelen: Román, S. (2020). Psykiatri och dödshjälp. I M. A. Horn, D. J. H. Kleiven \& M. Magelssen (Red.), Dødshjelp i Norden? Etikk, klinikk og politikk (Kap. 11, s. 213-233). Oslo: Cappelen Damm Akademisk. https://doi.org/10.23865/noasp.96.ch11.

Lisens: CC BY 4.o. 
inte ser någon möjlig väg ut, men att de innerst inne vill fortsätta leva. Det suicidala agerandet är ofta ett rop på hjälp i en förtvivlad situation, men kan också bero på en svår livskris utan något egentligt psykiatriskt tillstånd. Suicidaliteten handlar om att inte orka leva eller inte se lösningar på livets problem, men personen skulle inte vilja dö om lidandet kunde upphöra.

Många av de som gör mycket allvarliga suicidförsök vill inte heller dö. Hansen (2017) skriver om dödsönskan för de cirka 100 personer som överlevt ett fall från Golden Gate-bron i San Francisco: »Det tar ungefär fyra sekunder att nå vattenytan och samtliga överlevare hävdade i efterhand att de ångrade självmordsförsöket redan under fallet.»

Jag har bedömt hundratals barn som gjort ett suicidförsök. Självmordsförsöken har nästan alltid haft sin grund i ett psykiatriskt tillstånd, ofta depression eller svår ångestproblematik, till exempel emotionellt instabilt personlighetssyndrom (EIPS, tidigare benämnt borderline). För andra är huvudproblematiken ett psykiskt trauma, exempelvis någon form av övergrepp. En del har i botten autismproblematik och gör suicidförsöket i tonåren för att svårigheterna med det sociala samspelet då accentueras. I många fall är suicidförsöket en krisreaktion utlöst av olycklig kärlek.

När jag träffade dessa barn gjorde jag som vi i psykiatrin alltid gör. Jag lyssnade empatiskt och respektfullt. Jag försökte få veta varför de inte ville leva. Jag pratade med deras föräldrar och närmast anhöriga. Jag försökte få barnen på andra tankar. Jag försökte ingjuta hopp, berättade att jag mött väldigt många barn och ungdomar som mått dåligt och inte trott på någon framtid men efter lämplig behandling fått livslusten tillbaka. Jag involverade andra behandlare för fortsatta samtal med barnet och föräldrarna. Ibland satte jag ut mediciner som skulle kunna förvärra eller ha förorsakat tillståndet, ibland satte jag in andra mediciner som skulle kunna hjälpa. Nästan alla suicidala barn och ungdomar som jag har träffat har tillfrisknat. Hittills har ingen tagit sitt liv. Samtidigt är självmord ovanligt för barn, det sker 20 till 30 gånger per år i Sverige.

Vuxenpsykiatrin arbetar på precis samma sätt med suicidala patienter som barn- och ungdomspsykiatrin. I den absoluta majoriteten av fallen är även deras tillstånd behandlingsbara. Med rätt sorts samtalsbehandling, och ibland tillägg av mediciner, upphör deras dödsönskan (Reynolds, Lenze \& Mulsant, 2019). 


\subsection{Rationella suicid}

Beror alltid suicid på psykisk ohälsa? Finns rationella suicid? Är självmord begripligt om en person har levt ett långt liv och drabbats av sjukdom eller åldrande och därför inte längre kan leva fullödigt?

Det är tveksamt om rationella suicid existerar, om man avser att personen i grunden och i beaktande av möjligheter till förändring av livet över längre tid verkligen inte vill leva.

Då måste man bortse ifrån att kroppens pågående mekanismer går ut på att leva, att människan är en social varelse som är beroende av och interagerar med andra för att leva samt att de som blir kvar efter att en närstående tagit sitt liv ofta är fyllda av skuld och samvetskval. Det sistnämnda är något som personer i suicidnära tillstånd inte orkar ta in men i de flesta fall sannolikt inte önskar. Personer med suicidalitet rapporterar genomgående svåra skuldkänslor för sin suicidalitet. Att man har det förstärker i sig känslan av mindervärde och att vara en belastning för omgivningen, vilket bidrar till att det verkliga måendet och synen på livet blir något som man undanhåller för sina nära.

Rationella suicid, i betydelsen av att man ändå inte skulle ha önskat leva om hälsan hade varit i balans eller livsproblemen hade gått att hantera, motsägs av forskningen på suicid för personer över 65 år. De har betydligt oftare psykiatrisk problematik än yngre. I en studie av 85 patienter över 65 år som suiciderat hade 97 procent psykiatrisk problematik, 82 procent hade en förstämningsdiagnos (bipolärt syndrom eller någon depressionsdiagnos) och en fjärdedel hade alkoholmissbruk (Waern et al., 2002).

\subsection{Psykisk ohälsa hos patienter som önskar dödshjälp}

De flesta patienter som önskar dödshjälp gör det inte på grund av fysiska symtom. Avgörande för önskemål om dödshjälp är istället depression, psykologiskt lidande, förlust av autonomi, rädsla för att förlora kontroll, minskad förmåga att njuta av livet, att vara en börda för andra och livsleda (Sulmasy, 2017; se också kap. 10 och 14).

Sannolikt har många patienter som önskar dödshjälp en psykiatrisk diagnos. I en studie från Nederländerna av 138 cancerpatienter som bedömdes ha högst tre månader kvar att leva hade 14 av 30 av de som 
efterfrågade dödshjälp depression (Van der Lee et al., 2005). Många psykiatriska tillstånd är förknippade med dödshjälp, vanligast är depression. Psykiatriska tillstånd är oftast behandlingsbara, så många av dessa patienter borde istället för dödshjälp få adekvat behandling.

Många patienter som önskar dödshjälp och som inte tidigare haft någon psykiatrisk problematik lider sannolikt för första gången av psykisk och social ohälsa. De befinner sig alltid i en livskris och uppfyller kriterierna för diagnosen akut krisreaktion. Detta är vanligt hos patienter som fått beskedet att de drabbats av en obotlig sjukdom. Deras första tanke är ofta att de vill dö. I en australiensisk studie av 256 patienter med terminal cancer hade 14 procent en stark önskan om att förkorta livet (Kelly et al., 2003).

Detta är begripligt. Nästan alla människor känner i någon grad ångest inför vetskapen att de en gång ska dö. När vi får besked om att vi lider av en dödlig sjukdom och relativt snart kommer att dö, drabbas vi och närstående ofta av en existentiell kris. Bearbetningen av krisen färgas ofta av den underliggande dödsångesten. Den existentiella ångesten och ensamheten förstärker eventuell smärtupplevelse (Strang, 2013; 2016).

Terminala patienters dödsönskan upphör ofta när de får hjälp att förstå innebörden av god palliativ vård (kap. 10; Bongenhielm, Gyllenhammar \& Lundström, 2016). Övriga kan sannolikt, liksom övriga suicidala personer, med rätt behandling - psykiatrisk bedömning, adekvat samtalsbehandling och vid behov tillägg av medicin, hjälp och stöd från det privata nätverket och vid behov andra professionella aktörer som socialtjänst, äldrevård, företagshälsovård etc. - återupprätta ett värdigt liv och en fungerande problemlösning och bli av med sin dödsönskan.

\section{Problem med dödshjälp inom psykiatrin}

En annan viktig fråga är om psykiatriska patienter bör få dödshjälp. Nedan beskrivs fyra orsaker till att förslaget är problematiskt: Diagnostik av psykiatriska tillstånd är svår, prognosen är ofta osäker, behandlingsalternativ finns och det är särskilt viktigt inom psykiatrin att inte beröva patienterna hopp (Blikshavn, Husum \& Magelssen, 2016). 


\subsection{Svår diagnostik}

Samstämmigheten är ofta låg bland psykiatriker vid diagnostik av psykiatriska tillstånd. Det gäller flera av tillstånden som ökar suicidrisken. För till exempel depression är denna överensstämmelse, interbedömarreliabiliteten, endast 28 procent (Freedman et al., 2013). För allmänläkare är samstämmigheten ännu lägre, de underdiagnostiserar bland annat depression och ångesttillstånd (McCormack \& Price, 2014).

Psykiatriker som bara träffat en patient en gång känner sig sällan säkra på att bedöma om patienten har ett psykiatriskt tillstånd. Psykiatern Hans Olsson (2015) föreslår att läkaren ska träffa patienten på fem timslånga besök innan en psykiatrisk diagnos fastställs.

Forskning på patienter över 65 år talar för att deras depression förbises i skattningsskalor (Schayn, 2017). Det är också viktigt att i denna grupp fånga män. Deras symtombild ser annorlunda ut och självmorden är ofta kopplade till alkoholproblematik (Rutz, 2016).

Ett skäl till osäkerheten vid psykiatrisk diagnostik är att den skiljer sig från den somatiska. Somatiska diagnoser bygger på naturvetenskap: ofta sitter sjukdomen eller skadan på en speciell identifierbar plats och kan verifieras med naturvetenskapliga fynd från blodprover, röntgenundersökningar, cellprover med mera. Psykiatrisk diagnostik är deskriptiv och grundar sig på subjektiv bedömning av beteendesymtom. Ett visst kluster av symtom som presenterar sig på ett specifikt sätt och under en bestämd tidsrymd är depression, ADHD, posttraumatiskt stressyndrom (PTSD) eller något annat psykiatriskt tillstånd. Många symtom kan ingå i flera diagnoser och psykiatrisk samsjuklighet är mycket vanligt. Diagnosen säger inget om etiologin, orsaken, till tillståndet (Tsou, 2015).

Psykiatriska diagnoser är ofta heterogena. Det finns stark evidens för att depression är ett mycket heterogent tillstånd (Blikshavn et al., 2016). Symtomen kan uppstå av många orsaker. Psykosociala påfrestningar, som att ha varit mobbad i tonåren, är tydligt relaterat till depression hos vuxna men ingår inte i depressionskriterierna. I behandlingen av en specifik patient kan denna information vara avgörande för förståelsen och terapin. 


\subsection{Osäker prognos}

Att på individnivå ange en söker överlevnadsprognos som kan användas för att utvärdera om en patient bör få dödshjälp är mycket svårt, även för somatiska tillstånd. För psykiatriska tillstånd är det ännu svårare. Tillståndet ingår i en komplex och individuell biopsykosocial interaktion, där individens val och levnadssätt liksom samhället och kulturen inverkar unikt och oförutsägbart i varje enskilt fall. Därför kan prognosen vid psykiatriska tillstånd bara ges på gruppnivå (Blikshavn et al., 2016).

Vid analys på gruppnivå kan patienter ha genomfört många behandlingar med antidepressivum utan effekt. Informationen är dock av begränsat värde på individnivå, om det saknas förståelse för den enskilda patientens underliggande dynamik. Har patienten haft depression tidigare? Hur gammal är patienten? Hur ser det sociala nätverket ut, har patienten vänner, partner, familj? Vad har patienten för utbildningsnivå? Studerar eller arbetar patienten? Hur är patientens ekonomi? Finns det samsjuklighet och i så fall i vilken omfattning? Finns det missbruk?

Blikshavn et al. (2016) pekar också på att behandling fungerar i ett sammanhang. Detta gäller till exempel långvarig terapirefraktär depression (TRD), som forskningen oftast definierar som att en långvarig depression inte svarar på antidepressiv medicin. Tiden för återfall var betydligt längre om patienten hade ett starkt socialt stöd. Behandlingsresultatet för tonårs-TRD var bättre om behandlingen slutade under sommarledighet. Varken behandlare eller patient kan utifrån empiriska studier av TRD avgöra om just denna patient kan eller inte kan tillfriskna.

Överlevnadstiden vid psykiatriska tillstånd är ofta flera decennier. Patienterna dör i allmänhet inte av det psykiatriska tillståndet i sig, om det inte medför att de tar sitt liv eller utsätter sig för en sådan fara att de förolyckas, utan av somatiska komplikationer av sjukdomen, medicineringen och livsföringen.

Många med exempelvis långvarig och allvarlig depression kan också tillfriskna. Patienter beskriver ofta retrospektivt att faktorer utanför vården är avgörande för vändningen, såsom mellanmänskliga relationer, viktiga livshändelser, att få hjälp med arbete, hushållet eller ekonomin. 
Psykiatriska tillstånds osäkra prognos är ännu ett skäl till att vi behandlare inte ska bejaka patientens dödsönskan. Den är ett symtom på psykisk sjukdom, lidande och psykosocial nöd. Vår uppgift är att hjälpa patienten att återfå livslusten, hantera livet och skapa mening.

Vi ska utifrån Hippokrates, ed alltid trösta, ofta bota, ibland lindra och aldrig skada. Vi får aldrig överge patienten i hennes förtvivlan och livskamp.

\subsection{Behandlingsmöjligheterna}

Nästan alla psykiatriska tillstånd är behandlingsbara. Många går att bota. Möjligheten att hjälpa psykiatriska patienter har ökat påtagligt under efterkrigstiden. Några exempel på evidensbaserade behandlingar är elektrokonvulsiv terapi (ECT) vid djupa depressioner, litiummedicinering för att förebygga maniska skov vid bipolärt syndrom och psykoterapeutisk behandling vid depressions- och ångesttillstånd (Persson m.fl., 2017; Socialstyrelsen, 2017). EIPS, som efter depression är det vanligaste psykiatriska tillståndet hos patienter som önskar dödshjälp, har tidigare saknat bra behandling. Men sedan millennieskiftet har några psykoterapeutiska metoder visat goda resultat (Cristea, Gentili \& Cotet, 2017).

Dödshjälpsförespråkare hävdar att patienter med terapirefraktär depression, TRD, borde få dödshjälp. Begreppet TRD är dock tveksamt (Blikshavn et al., 2016). Många system för stadieindelning av depression har utvecklats, inget har dock utvärderats extensivt och alla ignorerar psykologisk behandling. Även Appelbaum (2017) kritiserar själva begreppet TRD. Patienter med TRD har svarat dåligt på endast ett antidepressivum och många har inte fått prova psykoterapi, ECT eller andra typer av mediciner och behandlingar.

Appelbaum poängterar att demoralisering och hopplöshet ofta är en del av det psykiatriska tillståndet. Att den psykiatriska patienten avbryter eller inte fullföljer behandlingar, betyder därför inte att det psykiatriska tillståndet är terapirefraktärt. Patientens önskan om dödshjälp vid resultatlös behandling är en konsekvens av depression, ångest och andra symtom som en effektiv behandling skulle lindra. Även om lagarna som styr dödshjälp kräver att personen ska vara beslutskompetent, är det svårt att 
bedöma när denna önskan är en del i det psykiatriska tillståndet. Det är vanligt att patienter som vägrar behandling på till synes rationella grunder ändrar sitt beslut så snart depressionen är effektivt behandlad.

Patientens föreställning om att symtomen aldrig kommer att försvinna kan vara en bra utgångspunkt för en psykoterapeutisk behandling (Blikshavn et al., 2016). Att hjälpa patienten att hitta orsakerna till och ändra denna övertygelse skulle kunna vara ett övergripande terapeutiskt mål.

I psykiatrisk behandling är alliansen med behandlaren essentiell. Behandlingsresistens behöver därför inte bero på patienten, utan kan bero på behandlarens förhållningssätt eller själva behandlingen. Långvarig psykoterapi för patienter med komplicerade ångest- och depressionstillstånd har visat stora förbättringar för symtomorienterade mått och psykosocial funktion.

\subsection{Vikten av att inge hopp}

Behandlarens förmåga att inge hopp och utsikter om en förbättring är en av de viktigaste faktorerna för psykiatrisk behandling. Många nya behandlingsmetoder ser detta som både nödvändiga professionella förhållningssätt och som egna terapeutiska interventioner direkt kopplade till utfallet. Att behandlaren står för ett ställföreträdande hopp skyddar den depressiva patienten från suicid (Blikshavn et al., 2016).

Positiva förväntningar korrelerar också med en positiv allians mellan behandlare och patient. Framgångsrik behandling är därför starkt relaterad till dessa egenskaper hos behandlaren. Om behandlaren istället bejakar patientens dödsönskan, blir behandlingsrelationen kraftlös eller till och med destruktiv, då den förstärker patientens brist på hopp. En sådan inställning riskerar att skapa en självuppfyllande profetia (Blikshavn et al., 2016).

\section{Konsekvenser av dödshjälp inom psykiatrin}

\subsection{Patienten}

Hur påverkas psykiatriska patienter av att det finns situationer där behandlaren ger upp hoppet om att patienten kan förbättras och tillåter 
dödshjälp? Psykiatripatienter är en av de mest sårbara patientgrupperna. Det har länge varit ett stigma att ha ett psykiatriskt tillstånd och att söka psykiatrisk vård (Flycht, 2015).

Patient-läkarrelationen i psykiatrin bygger på tillit. Sulmasy (2017) hävdar att en grundförutsättning för att den sköra psykiatriska patienten ska öppna sig inför psykiatern är att hen vet att psykiatern inte kommer att döda patienten. Luckras detta axiom upp, kan det få stora konsekvenser. Lemmens (2017) menar att denna ovillkorliga skyldighet mot de mest sårbara är grundläggande för att bibehålla solidaritet och hopp i ett samhälle.

Experientiellt undvikande (eng.: »experiential avoidance») är den naturliga instinkten att fly ifrån eller undvika obehagliga situationer och händelser, en vanlig psykologisk process vid psykisk ohälsa (Blikshavn et al., 2016). Exempel på experientiellt undvikande är olika grader av suicidalitet, såsom självmord och strävan att få dödshjälp. Dödshjälp för psykiatriska patienter kan förstärka experientiellt undvikande. I vissa psykoterapier arbetar man med att få patienten att ersätta det experimentella undvikandet med experientiellt acceptans. I behandling av suicidalitet och svåra depressioner är resultaten lovande.

Den empiriska litteraturen är överens om att det finns psykiatriska tillstånd, inklusive fall av depression, som tycks terapirefraktära för att behandlingen går ut på att kontrollera eller minska symtomen. En förändring kan dock ofta ske om behandlingen förändras till att få patienten att acceptera och förlikas med sitt lidande.

\subsection{Suicidtalen}

Dödshjälpsförespråkare hävdar att dödshjälp i form av läkarassisterat självmord skulle kunna senarelägga suicid och minska suicidtalen (Jones \& Paton, 2015). Hypotesen är att tillgången till ett dödligt läkemedel ger en trygghet för de fysiskt sjuka patienterna, vilket senarelägger deras suicid till en tidpunkt då lidandet blivit outhärdligt, och i vissa fall inte genomförs alls. Statistik från Nederländerna och fyra delstater i USA visar att det sannolikt är tvärtom.

I Nederländerna har sedan 2007 både antalet psykiatriska patienter som fått dödshjälp och antalet suicid ökat avsevärt. 2007 suiciderade 1353 
personer, 2017 var siffran 1917, den högsta någonsin (CBS, 2008; 2018). Samtidigt ökade antalet personer som fick dödshjälp från 2120 till 6585 personer (RTE, 2008; 2018; se också kap. 13).

För en korrekt bedömning av suicid- och dödshjälpstal måste hänsyn tas till Nederländernas befolkningstal. ${ }^{1}$ Då blir ökningen per 100000 invånare av antalet suicid och antalet som fått dödshjälp åren 2007 till 201736 och 198 procent. I övriga jämförbara länder har suicidtalen varit oförändrade eller sjunkit.

Jones och Paton (2015) redovisar suicidtalen 1990 till 2013 i fyra delstater i USA före och efter införandet av läkarassisterat självmord. Efter legaliseringen har antalet självmord ökat med 6 procent mer jämfört med stater som inte infört läkarassisterat självmord. I gruppen äldre än 65 år var ökningen 14 procent.

\subsection{Behandlaren och psykiatern}

Psykiatrins behandlare behöver inge patienten hopp. Vilka blir konsekvenserna om patienten samtidigt kan få dödshjälp? Då måste behandlaren ibland överge tanken att försöka inge hopp och skapa förbättring för patienten och istället acceptera patientens förtvivlan. Hur ska behandlaren kunna skifta mellan dess två diametralt motsatta sätt att bemöta patienten? (Blikshavn et al., 2016). Behandlaren måste tala med kluven tunga.

När det blivit socialt accepterat att medverka till en patients död, finns en fara att behandlaren agerar på den normala, ibland intensiva, negativa kommunikationen som kan uppstå i behandlar-patientrelationen. Behandlaren kan, medvetet eller omedvetet, påverka patientens beslut (Blikshavn et al., 2016).

Ger psykiatern, pressad av för mycket arbete på en klinik med för lite resurser, lättare upp behandlingen av svåra ärenden och kanske till och med subtilt medverkar till att patienten söker dödshjälp, om sådan är tilllåten (Appelbaum, 2017)? Kan stressade närstående agera likadant?

Eurostat-databas, https://ec.europa.eu/eurostat/data/database 
Mellan 30 och 50 procent av läkare som deltar i dödshjälp känner psykologiskt obehag, och 15 till 20 procent upplever bestående negativ påverkan (Kelly et al., 2019). Nederländernas psykiatriker avvisar dödshjälp för psykiatrins patienter, motståndet har ökat från 53 procent 1995 till 63 procent 2015 (De Rijksoverheid Voor Nederland, 2017).

Vi i psykiatrin försöker att i mötet med den suicidala patienten göra allt för att inge hopp och få patienten på andra tankar. Dödshjälp för psykiatriska patienter förändrar grunderna för vårt arbete. Som visats ovan kommer det sannolikt att påverka oss påtagligt. Suicidtalen för läkare i allmänhet är högre än i övriga befolkningen, för kvinnliga läkare mer än fördubblad (Schernhammer \& Colditz, 2004). Kommer denna nya arbetsuppgift medföra ännu fler läkarsuicid? Detta är inte beforskat, men att vara närstående till någon som suiciderat ökar risken för eget självmord (Runeson, 2017).

\section{Utvärdering av dödshjälp för psykiatrins patienter}

Alla länder och regioner som praktiserar dödshjälp inkluderar psykiatriska patienter, om önskemålet om dödshjälp inte bedöms vara påverkat av det psykiatriska tillståndet. Nedan redogörs för situationen i Belgien och Nederländerna, som tillåter både eutanasi och läkarassisterat självmord, samt de amerikanska delstaterna Oregon och Washington, som enkom legaliserat läkarassisterat självmord. I Belgien och Nederländerna inkluderas i utvärderingen bara de som på grund av psykiatriskt tillstånd får dödshjälp, i Oregon och Washington krävs dessutom att patienten bedöms ha högst sex månader kvar att leva på grund av ett somatiskt tillstånd.

\subsection{Belgien och Nederländerna}

\subsubsection{Förekomst}

Båda länderna legaliserade dödshjälp 2002. De första fem åren fick bara enstaka psykiatriska patienter dödshjälp, därefter steg antalet. I Belgien och Nederländerna fick år 201857 respektive 67 psykiatriska patienter dödshjälp (CFCEE, 2019; RTE, 2019). 


\subsubsection{Diagnoser}

Erfarenheten från Nederländerna och Belgien ger oss många exempel på hur komplicerade fallen med dödshjälp inom psykiatrin kan vara. I båda länderna har flertalet av patienterna som fått dödshjälp haft ett förstämningssyndrom (Kim, De Vries \& Pateet, 2016; Dierickx, Dellens, Cohen \& Chambaere, 2017; CFCEE, 2018). Omkring hälften hade två eller flera psykiatriska tillstånd och upplevde ensamhet eller isolering. Minst 15 procent hade EIPS. I den nederländska studien hade sex procent en neurokognitiv nedsättning som gör dem ännu mer sårbara, med svårbedömd beslutskompetens (Kim et al., 2016).

Hälften av 100 psykiatriska patienter i Belgien som ansökte om dödshjälp 2007 till 2011 hade personlighetssyndrom, varav 54 procent EIPS (Thienpont et al., 2015). Patienter med personlighetssyndrom är mycket ambivalenta och har ökad risk att fatta impulsiva beslut utifrån stress och problem i nära relationer, vilket sannolikt speglas av att 38 patienter drog tillbaka ansökan om dödshjälp innan den var färdigbehandlad (Appelbaum, 2017). 48 patienter beviljades dödshjälp och 35 fullföljde den, däribland flera patienter med EIPS, och även med autism.

\subsubsection{Svåra fall}

Många fall av dödshjälp för psykiatriska patienter har uppmärksammats i media. Fallen ger värdefull insikt i hur komplicerat det är att använda dödshjälp för dessa patienter. Ett fall handlar om en 25-årig kvinna som Dirk De Wachter, belgisk professor i psykiatri, beviljade eutanasi. Han ansåg att hon egentligen inte led av en klinisk depression, utan hade existentiella problem. Hon kunde helt enkelt inte se något syfte med sitt liv. Hennes föräldrar, lade De Wachter till, hade bönat och bett om att deras dotter skulle få dö (Aviv, 2015).

Ett annat fall är 29-åriga Aurelia Brouwers med EIPS och självskadebeteende, men fysiskt helt frisk (Pressly, 2018). Hon drev under flera år en kampanj i Nederländerna för dödshjälp för psykiskt sjuka och ungdomar. I sociala medier publicerade hon bilder på sig själv och artiklar som beskrev hennes kamp för dödshjälp. Till slut beviljades hon läkarassisterat självmord av Levenseindekliniek (mer om denna klinik, se kap. 13). De sista veckorna av sitt liv var hon mycket stressad och självskadade sig 
frekvent, vilket sannolikt speglar hennes ambivalens inför dödshjälpen. Patienter med EIPS måste psykiatriskt och mänskligt antas vilja leva, om lidandet och livsproblemen skulle kunna bli hanterbara och uthärdliga. Den starka ångesten gör dem förtvivlade, de tappar allt hopp och orkar inte fortsätta att söka hjälp för sitt lidande och en lösning av livsproblemen. Den 26 januari 2018 svalde Aurelia Brouwers det dödliga läkemedlet.

En 20 till 30 år gammal kvinna, utsatt för sexuella övergrepp från 5 till 15 års ålder, fick i Nederländerna eutanasi 2015 (RTE, 2015). Hon bedömdes ha en behandlingsresistent PTSD. Hon hade även bland annat anorexi, kronisk depression och självskadebeteende. Hon var dessutom fysiskt svag, var helt sängbunden. Två år före sin död sökte kvinnan upp en ny läkare och fick en intensiv traumabehandling, som under en period delvis var framgångsrik. Behandlingen övergavs 2015 då en oberoende konsult bedömde att patienten aldrig skulle tillfriskna.

Personer med neuropsykiatrisk diagnos, exempelvis ADHD och autismspektrumtillstånd (AST), får dödshjälp i Belgien och Nederländerna. En studie i Nederländerna av dödshjälp för nio patienter med intellektuell funktionsnedsättning eller AST sammanfattar att bedömningarna är mycket bristfälliga, att det är svårt att bedöma autonomi och beslutskapacitet vid dessa tillstånd, att testerna som gjordes inte var tillräckligt stringenta och att det är särskilt svårt att bedöma lidande för patienter som har haft livslång funktionsnedsättning (Tuffrey-Wijne, Curfs, Finlay \& Hollins, 2018).

Även från Belgien finns fallbeskrivningar av dödshjälp för patienter med autism. Ett exempel rör en 38-årig autistisk kvinna (Melville, 2019, s. 1). Familjen har ifrågasatt patientens autismdiagnos, fastställd två månader innan dödshjälpen utfördes. De hävdar att hon hade en depression orsakad av en nyligen avslutad kärleksrelation. Ärendet har anmälts till vanlig domstol.

\subsubsection{Könsfördelning}

Studier från båda länderna tyder på att minst 70 procent av de psykiatriska patienterna som får dödshjälp är kvinnor (Thienpont et al., 2015; Kim, De Vries \& Pateet, 2016). Det indikerar att kvinnor med psykiatriska tillstånd är mer sårbara för att få dödshjälp. För självmord är det 
tvärtom, i EU 2011 till 2015 stod män för fyra av fem självmord enligt Eurostat-databasen.

Könsfördelningen är anmärkningsvärd. Kvinnor gör betydligt fler suicidförsök än män, men använder sig oftare av tabletter. Det ökar chansen att överleva, vilket är en delförklaring till kvinnors lägre suicidtal. Att kvinnor använder mindre definitiva metoder för sina självmordsförsök kan vara ett uttryck för att de är mer ambivalenta i beslutet om de verkligen vill dö. Genom dödshjälp dör de obönhörligen.

\subsection{5 ^̊lder}

Psykiatriska patienter som fått dödshjälp har varit betydligt yngre än övriga patienter. Av samtliga som fick dödshjälp i Belgien 2014 till 2017 var 1,4 procent yngre än 40 år, motsvarande siffra för psykiatriska patienter var 21 procent (CFCEE, 2016; 2018). Nederländerna visar liknande resultat. Detta är svårförståeligt, då psykiatriska tillstånd, som beskrivits ovan, har en lång förväntad överlevnad och oftast är behandlingsbara.

\subsubsection{Bristande regelverk}

Den nederländska studien av Kim et al. (2016) visar att i över hälften av fallen var inte alla behandlingsmöjligheter uttömda, då patienten vägrat ta del av något eller några alternativ som hade kunnat förbättra deras tillstånd. Därmed kan tillstånden inte betraktas som terapirefraktära. Drygt en fjärdedel dog med hjälp av en läkare som inte tidigare varit inblandad i deras behandling och som bara känt patienten några dagar eller veckor (Appelbaum, 2016; se även kap. 13).

Det var vanligt att läkarna inte var överens om att kriterierna för dödshjälp var uppfyllda och att den oberoende och obligatoriska psykiatriska bedömningen saknades. Eventuella brister i hanteringen av dödshjälpen påpekas dessutom av anhöriga till patienterna, inte av de granskande myndigheterna.

\subsubsection{Shopping for doctors, dödshjälpsläkare och dödshjälpskliniker}

I båda länderna kan en patient som nekats dödshjälp av en läkare vända sig till andra läkare för både en »second» och »third opinion», så kallad 
»shopping for doctors». I Belgien finns en enskild psykiater som ensam står för 35 till 50 procent av landets dödshjälp för psykiatriska patienter (Claes et al., 2015).

I Nederländerna bistår ofta den särskilda eutanasikliniken Levenseindekliniek i Haag med en "second opinion». Verksamheten startade 2012, och har ett halvt dussin mobila team som kan ge patienter den dödliga injektionen i deras egna hem. 2017 stod Levenseindekliniek för 62 procent av all dödshjälp till psykiatriska patienter (RTE, 2018; se även kap. 13).

\subsection{Oregon och Washington}

Oregon och Washington införde som de första amerikanska delstaterna läkarassisterat självmord 1997 och 2009 (se även kap. 14). Patienternas skäl till dödshjälp är främst psykologiska och psykosociala. En majoritet, 50 till 90 procent, anger minskad autonomi, svårigheter att delta i glädjefyllda aktiviteter, minskad värdighet samt att de är en börda för familjen som de främsta skälen till dödshjälp (Oregon Health Authority, 2019; Washington State Department of Health, 2018, s. 8).

Trots att de som fick läkarassisterat självmord i Oregon och Washington oftast angav psykologiska och sociala skäl, är det få som bedömts av en psykiater och andelen minskar. De första åren bedömdes nästan var fjärde patient, de senaste åren har var femtionde patient bedömts av en psykiater. I en studie från Oregon före legaliseringen ansåg bara sex procent av psykiatrikerna att de efter ett enstaka besök var tillfreds med bedömningen av om en psykiatrisk patient som ansökte om läkarassisterat självmord (PAS) var beslutskapabel (Ganzini et al., 1996). Således krävs oftast flera besök för att göra en korrekt bedömning.

Enligt delstaternas lagar kan en patient med ett psykiatriskt tillstånd få PAS, om patienten bedöms beslutskapabel. Förfarandet är mycket tveksamt. Ett psykiatriskt tillstånd bör enligt min uppfattning utesluta dödshjälp, eftersom dödsönskan ingår som ett symtom i det psykiatriska tillståndet som nästan alltid är behandlingsbart.

I Oregon kan en psykiatrisk patient få dödshjälp även på annat sätt. Om patienten avstår behandling och därmed bedöms ha högst sex månader kvar att leva, kan hen få dödshjälp (Andreen et al., 2018). Flera fall 
där patienter har avbrutit sådan livsuppehållande behandling för att därmed få PAS har konstaterats. Psykiatriska patienter som är suicidala kan därmed få dödshjälp genom att avsluta en livsuppehållande somatisk eller psykiatrisk behandling, till exempel vid en djup depression tacka nej till ECT.

\section{Slutsats}

Inom psykiatrin ser vi dödsönskan som ett symtom på ett psykiatriskt tillstånd eller en livskris. Denna i vid bemärkelse psykiska ohälsa är utifrån forskning och väl beprövad erfarenhet nästan alltid behandlingsbar med hjälp av samtalsbehandling och ibland tillägg av mediciner. Detta är ett av många skäl till att dödshjälp till en psykiatrisk patient bör vara helt uteslutet.

Utifrån forskning på patienter som önskar dödshjälp har många ett psykiatriskt tillstånd eller en livskris. De bör få samma behandling som de självmordsbenägna psykiatriska patienterna. Med stor sannolikhet blir många därmed av med sin önskan om dödshjälp. Psykiatrin kan inte särskilja de som borde få hjälp att leva och de som borde få dö.

\section{Referenser}

Andreen, J., Ståhle, F., Luthman, M., Herlofson, J., Wasserman, D., Jacobsson, L. ... Fritzell. K. (2018, 22 februari). Risk att suicidala ges dödshjälp med ny modell. Svenska Dagbladet. Hämtad från https://www.svd.se/risk-att-suicidala-gesdodshjalp-med-oregons-modell

Appelbaum, P. S. (2016). Physician-assisted death for patients with mental disorder reasons for concern. JAMA Psychiatry, 73(4), 325-326.

Appelbaum, P. S. (2017). Should mental disorders be a basis for physician-assisted death? Psychiatry Online, 68(4), 315-317. https://doi.org/10.1176/appi.ps.201700013

Aviv, R. (2015, 22 juni). Letter from Belgium. The death treatment. When should people with a non-terminal illness be helped to die? The New Yorker. Hämtad från https://www.newyorker.com/magazine/2015/06/22/the-death-treatment

Blikshavn, T., Husum, T. L. \& Magelssen, M. (2016). Four reasons why assisted dying should not be offered for depression. Journal of Bioethical Inquiry, 14(1), 151-157. 
Bongenhielm, A., Gyllenhammar, E. \& Lundström, S. (2016, 5 februari). Sverige halkar inte efter i dödshjälpsfrågan. Dagens Nyheter. Hämtad från https://www. dn.se/debatt/repliker/sverige-halkar-inte-efter-i-dodshjalpsfragan/

Centraal Bureau voor de Statistiek (CBS). (2008). Laagste aantal zelfdodingen sinds 1975. Hämtad från https://www.cbs.nl/nl-nl/nieuws/2008/39/laagste-aantalzelfdodingen-sinds-1975

Centraal Bureau voor de Statistiek (CBS). (2018). 1917 zelfdodingen in 2017. Hämtad från https://www.cbs.nl/nl-nl/nieuws/2018/27/1-917-zelfdodingen-in-2017

Claes, S., Vanbouwel, L., Haekens, A., Eneman, M., Otte, G., De Lepeleire, J., ... Lemmens, W. (2015). Euthanasia for psychiatric patients: Ethical and legal concerns about the Belgian practice. Letter to the editor. BMJ Open. Hämtad från https://bmjopen.bmj.com/content/5/7/eoo7454.responses\#euthanasia-forpsychiatric-patients-ethical-and-legal-concerns-about-the-belgian-practice Commission fédérale de contrôle et d'évaluation de l'euthanasie (CFCEE). (2016). Septième rapport aux Chambres législatives, années 2014-2015. Hämtad från https://organesdeconcertation.sante.belgique.be/sites/default/files/documents/ 7_rapport-euthanasie_2014-2015-fr.pdf

Commission fédérale de contrôle et d'évaluation de l'euthanasie (CFCEE). (2018). 8e rapport aux Chambres législatives - Chiffres des années 2016-2017. Hämtad från https://organesdeconcertation.sante.belgique.be/sites/default/files/documents/ 8_rapport-euthanasie_2016-2017-fr.pdf

Commission fédérale de contrôle et d'évaluation de l'euthanasie (CFCEE). (2019). Chiffres de l’année 2018. Hämtad från https://organesdeconcertation.sante. belgique.be/fr/documents/euthanasie-chiffres-de-lannee-2018

Cristea, I. A., Gentili, C. \& Cotet, C. D. (2017). Efficacy of psychotherapies for borderline personality disorder: A systematic review and meta-analysis. JAMA Psychiatry, 74(4), 319-328.

Dierickx, S., Dellens, L., Cohen, J. \& Chambaere, K. (2017). Euthanasia for people with psychiatric disorders or dementia in Belgium: Analysis of officially reported cases. BMC Psychiatry, 17.

Flycht, L. (2015). Schizofreni är fortfarande en stigmatiserande sjukdom. Läkartidningen, 112(42). Hämtad från https://lakartidningen.se/klinik-ochvetenskap-1/artiklar-1/etik-och-lakarroll/2015/10/schizofreni-ar-fortfarande-enstigmatiserande-sjukdom/

Freedman, R., Lewis, D. A., Michels, R., Pine, D. S., Schultz, S. K., Tamminga, C. A., ... Yager, J. (2013). The initial field trials of DSM-5: New blooms and old thorns. American Journal of Psychiatry, 170(1), 1-5.

Ganzini, L., Fenn, D. S., Lee, M. A., Heintz, R. T., Bloom, J. D. (1996). Attitudes of Oregon psychiatrists towards assisted suicide. American Journal of Psychiatry, 153(11), 1469-1475. 
Hansen, A. (2017, 29 juni). Överläkaren: Flera självmord skulle kunna undvikas. Svensk Dagbladet. Hämtad från https://www.svd.se/overlakaren-mangasjalvmord-skulle-kunna-undvikas

Jones, D. A. \& Paton, D. (2015). How does legalization of physician-assisted suicide affect rates of suicide? Southern Medical Journal, 108(10), 599-604. Hämtad från https://pdfs.semanticscholar.org/6df3/55333ceecc41b361da6dc996d9oa17b96e9c.pdf

Kelly, B., Burnett, P., Pelusi, D., Badger, S., Varghese, F. \& Robertson, M. (2003). Factors associated with the wish to hasten death: A study of patients with terminal illness. Psychological Medicine, 33(1), 75-81.

Kelly, B., Handley, T., Kissane, D., Vamos, M. \& Attia, J. (2019). »An indelible mark» The response to participation in euthanasia and physician-assisted suicide among doctors: A review of research findings. Palliative \& Supportive Care, online first 25 juli. https://doi.org/10.1017/S1478951519000518

Kim, S. Y. H., De Vries, R. G. \& Peteet, J. R. (2016). Euthanasia and assisted suicide of patients with psychiatric disorders in the Netherlands 2011 to 2014. JAMA Psychiatry, 73(4), 362-368. https://doi.org/10.1001/jamapsychiatry.2015.2887

Lemmens, W. (2017). Psychiatric patients and the culture of euthanasia in Belgium. I D. A. Jones, C. Gastmans, C. MacKellar (Red.), Euthanasia and assisted suicide. Lessons from Belgium (s. 258-277). Cambridge: Cambridge University Press.

McCormack, R. \& Price, A. (2014). Psychiatric review should be mandatory for patients requesting assisted suicide. General Hospital Psychiatry, 36(1), 7-9.

Melville, N. A. (2019, 19 februari). Criminal case spurs a rethink of euthanasia for mental illness. Medscape Medical News. Hämtad från https://www.medscape. com/viewarticle/909233

Olsson, H. (2015). Sätt en »broms» på diagnoserna inom psykiatrin. Läkartidningen, 112(13). Hämtad från http://www.lakartidningen.se/Opinion/Debatt/2015/03/Satten-broms-pa-diagnoser-inom-psykiatrin/

Oregon Health Authority. (2019). Death with dignity annual reports. Oregon's Death with Dignity Act - 2018. Hämtad från https://www.oregon.gov/oha/ PH/PROVIDERPARTNERRESOURCES/EVALUATIONRESEARCH/ DEATHWITHDIGNITYACT/Documents/year21.pdf

Persson, C., Kardell, M., Annerbrink, K., Isgren, A., Karanti, A., Landén, M. (2017). Läkemedelsriktlinjer för bipolär sjukdom följs i hög utsträckning. Läkartidningen, 114(1-2), 1-4. Hämtad från https://lakartidningen.se/klinik-och-vetenskap-1/ artiklar-1/originalstudie/2017/o1/lakemedelsriktlinjer-for-bipolar-sjukdom-foljsi-hog-utstrackning/

Pressly, L. (2018, 9 augusti). The troubled 29-year-old helped to die by Dutch doctors. BBC News, The Netherlands. Hämtad från https://www.bbc.com/news/ stories- 45117163 
Reynolds, C. F., Lenze, E. \& Mulsant B. H. (2019). Assessment and treatment of major depression in older adults. Handbook of Clinical Neurology, 167, 429-435.

De Rijksoverheid Voor Nederland. (2017). Derde evaluatie Wet toetsing levensbeëindiging op verzoek en hulp bij zelfdoding. Haag, ZonMw, 2017, series of evaluation regulations, part 40. Hämtad från https://www.rijksoverheid. nl/documenten/rapporten/2017/05/23/derde-evaluatie-wet-toetsing levensbeeindiging-op-verzoek-en-hulp-bij-zelfdoding

RTE. (2015). Regionale Toetsingcommissie Euthanasie. Hämtad från tttps://www. euthanasiecommissie.nl/uitspraken/publicaties/oordelen/2015/psychiatrisch/ oordeel-2015-64

RTE. (2018). Regionale Toetsingcommissie Euthanasie. Jaarverslag 2017. Hämtad från https://www.euthanasiecommissie.nl/de-toetsingscommissies/uitspraken, jaarverslagen $/ 2017 / \mathrm{mei} / 17 /$ jaarverslag-2017

RTE. (2019). Regionale Toetsingcommissie Euthanasie. Jaarverslag 2018. Hämtad från https://www.euthanasiecommissie.nl/de-toetsingscommissies/uitspraken jaarverslagen/2018/april/11/jaarverslag-2018

Runeson, B. (2017). Partners suicid kopplades till ökad risk för suicid och sjukdom. Läkartidningen, 114(17). Hämtad från http://lakartidningen.se/Klinik-ochvetenskap/Nya-ron/2017/o3/Partners-suicid-okade-risk-for-suicid-psykisk-ochsomatisk-sjukdom/

Rutz, W. (2016). Manlig depression, stress och suicid i förändringstider. Tidskriften för Svensk Psykiatri, (4), 34-36. Hämtad från http://www.svenskpsykiatri.se/wpcontent/uploads/2017/02/SP-nr-4-2016.pdf

Schayn, M. (2017, 17 maj). Forskning om suicid och äldre ligger efter enormt.

Svenska Dagbladet. Hämtad från https://www.svd.se/forskare-racker-inte-att-gealdre-antidepressiva

Schernhammer, E. S. \& Colditz, G. A. (2004). Suicide rates among physicians: A quantitative and gender assessment (meta-analysis). The American Journal of Psychiatry, 161, 2295-2302. Hämtad från https://ajp.psychiatryonline.org/doi/

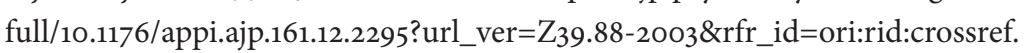
org\&rfr dat $=$ cr pub\%3dpubmed

Socialstyrelsen. (2017). Vård vid depression och ångestsyndrom: Stöd för styrning och ledning. Hämtad från https://www.socialstyrelsen.se/Lists/Artikelkatalog Attachments/20743/2017-12-4.pd

Strang, P. (2013). Existentiell kris - varför behöver den beforskas? Socialmedicinsk tidskrift, 9o(1), 127-131.

Strang, P. (2016). Existentiell kris i livets slutskede förstärker de fysiska symtomen. Minskad ångest och känsla av gemenskap kan minska upplevelsen av smärta. Läkartidningen, 113(47), 1-3. Hämtad från https://lakartidningen.se/klinik-och- 
vetenskap-1/artiklar-1/temaartikel/2016/11/existentiell-kris-i-livets-slutskede forstarker-de-fysiska-symtomen

Sulmasy, D. P. (2017). Ethics and the psychiatric dimensions of PAS. I D. A. Jones, C. Gastmans, C. MacKellar (Red.), Euthanasia and assisted suicide. Lessons from Belgium (s. 49-64). Cambridge: Cambridge University Press.

Thienpont, L., Verhofstadt, M., Van Loon, T., Distelmans, W., Audenaert, K. \& De Deyn, P. P. (2015). Euthanasia requests, procedures and outcomes for 100 Belgian patients suffering from psychiatric disorders: A retrospective, descriptive study. BMJ Open, 5, eoo7454. Hämtad frånhttps://bmjopen.bmj.com/content/5/7 eoo7454

Tsou, J. Y. (2015). DSM-5 and psychiatry's second revolution: Descriptive vs. theoretical approaches to psychiatric classification. I S. Demazeux \& P. Singy (Red.), The DSM-5 in perspective (s. 43-62). Springer.

Tuffrey-Wijne, I., Curfs, L., Finlay, I. \& Hollins, S. (2018). Euthanasia and assisted suicide for people with an intellectual disability and/or autism spectrum disorder: An examination of nine relevant euthanasia cases in the Netherlands (20122016), BMC Medical Ethics, 19, 17. https://doi.org/10.1186/s12910-018-0257-6

Van der Lee, M. L., van der Bom, J. G., Swarte, N. B., Heintz, A. P., de Graeff, A. \& van den Bout, J. (2005). Euthanasia and depression: A prospective cohort study among terminally ill cancer patients. Journal of Clinical Oncology, 23(27): 66076612.

Waern, M., Runeson, B., Allebeck, P., Beskow, J., Rubenowitz, E., Skoog, I. \& Wilhelmsson, K. (2002). Mental Disorder in elderly suicides: A case-control study. The American Journal of Psychiatry, 159(3), 450-455. Hämtad från https:// ajp.psychiatryonline.org/doi/full/10.1176/appi.ajp.159.3.450

Washington State Department of Health. (2018). 2017 Death with Dignity Act report. Hämtad från https://www.doh.wa.gov/Portals/1/Documents/Pubs/422-109DeathWithDignityAct2017.pdf.

\section{Ordforklaringer}

anhängare: tilhengere $(D, N)$

enkom: specifikt (D), utelukkende (N)

förfarandet: proceduren (D), prosessen (N)

förhållningssätt: måte at/å forholde sig/seg på (D/N)

förknippade: forbundet med $(\mathrm{D}, \mathrm{N})$

hopp: håb $(\mathrm{D})$, håp $(\mathrm{N})$

i vid bemärkelse: i vid forstand $(D, N)$

känna: føle (D, N) 
lämplig: adekvat $(\mathrm{D}, \mathrm{N})$

måendet: tilstanden $(\mathrm{D}, \mathrm{N})$

mått dårligt: har følt sig/seg dårlig, hatt det dårlig $(\mathrm{D} / \mathrm{N})$

påfrestingar: belastninger $(\mathrm{D}, \mathrm{N})$

senerelägga: utskyde $(\mathrm{D})$, utsette $(\mathrm{N})$

sette ut/sette inn: seponere, initiere (om behandling) $(\mathrm{D}, \mathrm{N})$

självmordsbenägna: selvmordstruede $(\mathrm{D}, \mathrm{N})$

skattningsskalor: scoringssystemer $(\mathrm{D}, \mathrm{N})$

skov: tilbagefald (D), forverring $(\mathrm{N})$

skyldighet: pligt (D), plikt (N)

skäl: årsag (D), årsak (N)

syfte: formål $(\mathrm{D}, \mathrm{N})$

undanhåller: tilbageholder/holder tilbake $(\mathrm{D} / \mathrm{N})$

uthärdliga: til at/å holde ud/ut(D/N)

utvärdera: evaluere $(\mathrm{D}, \mathrm{N})$

varelse: skabning $(\mathrm{D})$, skapning $(\mathrm{N})$

vattenytan: vandoverfladen $(\mathrm{D})$, vannflaten $(\mathrm{N})$

vetskapen: erkendelsen (D), erkjennelsen $(\mathrm{N})$

ärenden: tilfelder (D), saker (N) 



\title{
Er det at blive gammel tilstrækkelig årsag til dødshjælp?
}

\author{
Søren Holm \\ Centre for Social Ethics and Policy, Department of Law, University of \\ Manchester og Senter for Medisinsk Etikk, Universitetet i Oslo
}

\begin{abstract}
A proposal put forth in the Dutch Parliament suggests that anyone over the age of 75 should have a legally guaranteed right to physician-assisted suicide if they wish to die, unless the wish is the result of a mental illness. This chapter discusses three questions about the relationship between age and entitlement to assisted dying: 1) are there good reasons to introduce a purely age-determined criterion for a right to assisted dying; 2) would such an age criterion lead to problematic discrimination against the elderly, or alternatively to discrimination against people who are too young to meet the criterion; and 3) what is the relationship between an age criterion and a postulated duty to choose assisted dying in specific situations. The discussion of these three issues shows that there are no good reasons for introducing an age criterion for the right to die, that an age criterion is potentially discriminatory to both the elderly and the young, and that introducing an age criterion could lead to problematic pressure against vulnerable elderly people.
\end{abstract}

Keywords: age criterion, assisted dying, discrimination, euthanasia

\section{Indledning}

Holland er det land i verden der først eksplicit lovliggjorde dødshjælp. Forud for den eksplicitte lovliggørelse i 2002 var der en lang periode hvor både eutanasi og lægeassisteret selvmord var accepteret i den forstand at læger der udførte disse handlinger automatisk fik henlagt deres sager af anklagemyndigheden hvis de havde fulgt et sæt af retningslinjer udstukket af den hollandske lægeforening (se kap. 13). Holland giver os derfor

Sitering av denne artikkelen: Holm, S. (2020). Er det at blive gammel tilstrækkelig årsag til dødshjælp? I M. A. Horn, D. J. H. Kleiven \& M. Magelssen (Red.), Dødshjelp i Norden? Etikk, klinikk og politikk (Kap. 12, s. 235-247). Oslo: Cappelen Damm Akademisk. https://doi.org/10.23865/noasp.96.ch12.

Lisens: CC BY 4.0. 
mulighed for at få en idé om hvad der sker når dødshjælp lovliggøres i et moderne, velordnet, europæisk demokrati.

Der er stor uenighed om hvordan den officielle hollandske dødshjælpsstatistik skal fortolkes, og fortolkningerne synes ofte at afhænge mere af hvilken holdning forfatteren har til dødshjælp end til selve tallene (Holm, 2015). En ting som imidlertid er uomtvistelig er at adgangen til dødshjælp er blevet gradvist udvidet til nye grupper af patienter siden loven trådte i kraft i 2002. Dette er sket ved at fortolke lovgivningens betingelser for dødshjælp i mere og mere liberal retning (kap. 13).

En anden udvikling vi kan se i Holland er at dødshjælp er blevet en normaliseret medicinsk og social praksis som ikke længere ses som noget ekstraordinært (se kap. 13), og at der fra hollandske borgere og politikere i de senere år har været en række initiativer som har haft til formål at give adgang til dødshjælp til grupper som ikke har nogen medicinsk lidelse. I dette kapitel vil jeg analysere spørgsmålet om alene det at være blevet gammel skal give adgang til dødshjælp. Dette har været diskuteret på det politiske niveau i Holland siden 2010 hvor et borgerinitiativ samlede 116.871 underskrifter for at få assisteret selvmord lovliggjort for alle over 70 år som ønsker det (se kap. 13 og van Wijnaarden et al., 2017 for en god oversigt over de hollandske forhold).

I 2016 stillede partiet D66 ${ }^{1}$ forslag i parlamentet om at de sædvanlige kriterier for adgang til lægeassisteret selvmord skulle ophæves for personer som er 75 år eller ældre. D66 mener egentlig at alle som har beslutningskompetence skal have ret til dødshjælp på begæring, men anser det ikke for politisk muligt at ændre den hollandske lovgivning så radikalt på nuværende tidspunkt. ${ }^{2}$ Forslaget som blev fremsat indebar at de ældre skulle have ret til dødshjælp hvis de ønskede det og ønsket ikke var en følge af psykisk sygdom. Der var altså tale om et forslag om ret til dødshjælp på begæring for de ældre. Forslaget blev ikke vedtaget, men i debatten i parlamentet udtalte den hollandske sundhedsminister sig positivt

1 D66 er et social-liberalt parti som i dansk sammenhæng måske bedst kan forstås som placeret et sted mellem Det Radikale Venstre og Socialistisk Folkeparti. Det er interessant at bemærke at et af D66's nuværende parlamentsmedlemmer Annelien Bredenoord har en baggrund i akademisk bioetik.

2 https://nos.nl/artikel/2160953-pechtold-waardig-levenseinde-op-termijn-ook-voor-mensenjonger-dan-75.html 
om ideen og lovede at regeringen ville udforme sit eget lovforslag. ${ }^{3}$ Et sådant forslag fra regeringens side er dog endnu ikke fremsat, så D66 arbejder på at fremsætte deres eget forslag i 2020. ${ }^{4}$

Dette kapitel vil analysere hvordan vi bør opfatte sådanne forslag om at personer, alene på grund af deres alder skal have adgang til dødshjælp. ${ }^{5}$ Det er klart at høj kronologisk alder i sig selv ikke kan retfærdiggøre adgang til dødshjælp. Når vi anvender rene alderskriterier i lovgivning er det enten fordi der er en sammenhæng mellem alder og andre underliggende karakteristika som det er svært at måle direkte, for eksempel sammenhæng mellem myndighedsalder og alder for erhvervelse af kørekort og kognitive evner og modenhed, eller fordi der er en sammenhæng mellem alder og socioøkonomiske forhold, for eksempel billigere buskort eller reduceret TV-licens for alle over pensionsalderen. Det betyder at hvis alder skal være et kriterium for dødshjælp, må det være fordi der er en pålidelig sammenhæng mellem alder og et eller flere andre forhold som alene eller i kombination kan begrunde adgang til dødshjælp. Når vi efterspørger en pålidelig sammenhæng, betyder det ikke at alle ældre over den valgte alder skal udvise de forhold som kan begrunde adgang til dødshjælp, men at disse forhold er så stærkt korreleret med alder at de forekommer meget hyppigere blandt de ældre end blandt de unge.

I det følgende vil vi analysere to mulige forhold som kan hævdes at korrelere til alder, nemlig:

1. Selvbestemmelse og det færdig-levede liv

2. Alder og lidelse.

Vi vil derefter analysere om et alderskriterium for adgang til dødshjælp diskriminerer mod de ældre, eller måske mod de yngre; og hvad konsekvenserne af at indføre et sådant kriterium kunne være.

3 https://www.nytimes.com/2016/10/14/world/europe/dutch-law-would-allow-euthanasiafor-healthy-elderly-people.html

4 https://nltimes.nl/2019/o9/o2/d66-working-bill-assisted-suicide-end-completed-life

5 I den anden ende af aldersspektret kan kronologisk alder have juridisk betydning hvis f.eks. den almindelige myndighedsalder bruges om afgrænsning af de tilfælde hvor et ungt menneske selvstændigt kan tage beslutning om dødshjælp. 


\section{Alder og begrundelse - selvbestemmelse og det færdig-levede liv}

Den officielle begrundelse for forslagene om at give adgang til dødshjælp efter et rent alderskriterium er at man som gammel kan opleve at ens liv er levet færdigt og at der (derfor?) ikke er mere at leve for. Dette argument er en parallel til det som kaldes »the fair innings «-argument ${ }^{6} \mathrm{i}$ litteraturen om prioritering i sundhedsvæsenet (Callahan, 1995; Williams, 1997). Grundidéen i begge argumenter er at der er en række ting der sekventielt indgår $i$ et menneskes liv, og når man har opnået og oplevet alle disse ting har man et færdig- eller fuld-levet liv. Der er ikke mere man skal opnå, eller har krav på at opnå. I prioriteringsdiskussionen bruges argumentet til at begrunde at de ældre ikke har samme ret til dyr, livreddende behandling som de yngre der endnu ikke har et færdig-levet liv; og i dødshjælpsdebatten til at begrunde at der ikke skal være begrænsninger i adgangen til dødshjælp for de ældre som mener at de har et færdig-levet liv og ønsker dødshjælp. I dødshjælpskonteksten er der derfor tre præmisser i spil, nemlig 1) mange/nogle ældre har levet et færdiglevet liv, 2) det er forståeligt at ønske dødshjælp hvis man opfatter at ens liv er færdiglevet, for eksempel fordi mere liv derfor bliver meningsløst, og 3) et forståeligt dødshjælpsønske skal respekteres ved at muliggøre adgang til dødshjælp fordi et sådant ønske udtrykker personens selvbestemmelse.

Alle tre præmisser kan problematiseres. Den første præmis er problematisk fordi det er vanskeligt at definere de nødvendige og tilstrækkelige kriterier for at have et færdiglevet liv. Umiddelbart kunne vi forestille os at det må være kriterier som svarer til traditionelle afbildninger af en livsbue med barndom, ungdom, voksenliv med job, børn og familie, og måske en slutfase som bedste- eller oldeforælder. Men hvis job og familie er nødvendige kriterier betyder det at den person som indtræder i en kontemplativ munkeorden som ung mand aldrig kan opnå et færdiglevet liv, med mindre han udtræder af ordenen og får sig et job og en familie. Men det er ikke plausibelt, specielt nu hvor flere og flere vælger et liv uden

6 Dette er en reference til cricket hvor hvert hold har en eller flere »innings « hor de kan forsøge at score så mange »runs" som muligt. Et hold har haft en »fair inning« hvis de har haft samme mulighed som modstanderne til at score i deres inning. 
børn. På samme måde måtte vi sige at alle de som aldrig kommer ind på arbejdsmarkedet eller finder sig en livspartner aldrig får et færdiglevet liv, men det er heller ikke plausibelt. I stedet kunne vi sige at når ens livsprojekt er fuldendt har man et færdiglevet liv. Men det er også problematisk, dels fordi mange ikke har et ekspliciteret livsprojekt, dels fordi der ikke er noget i vejen for at man kan have mange tidsligt overlappende livsprojekter. Hvis vi ikke kan opstille objektive kriterier for om et liv er færdiglevet, betyder det at det bliver et subjektivt spørgsmål. Mit liv er færdiglevet når jeg oplever det som færdiglevet, men denne subjektive forståelse af det færdiglevede liv hænger ikke sammen med alder. Jeg kan opleve mit liv som færdiglevet når min første kæreste går fra mig eller når mit yndlingsfodboldhold taber eller rykker ned $\mathrm{i}$ anden række, helt uafhængigt af min alder.

Den anden præmis er problematisk på to måder. For det første fordi forståeligheden af at ønske dødshjælp når man føler at ens liv er færdiglevet, til en vis grad hænger sammen med den objektive forståelse af et færdiglevet liv. De fleste vil være villige til at sige til den 17-årige som opfatter sit liv som færdiglevet fordi hans første kæreste er gået fra ham at han simpelthen tager fejl. Hans liv er ikke færdiglevet og han har ingen god begrundelse for at ønske dødshjælp. Det andet problem er at det at have et færdiglevet liv i den forstand at man har opnået alt det som indgår i et »objektivt« set færdiglevet liv ikke betyder at de yderligere leveår man kan få ikke kan være gode og meningsfulde leveår. Der er ingen nødvendig sammenhæng mellem at have nået enden af sin livsbane og mangel på livskvalitet. Da Sir Alex Ferguson stoppede som Manchester United manager efter mange års succes havde han både børn og børnebørn, og havde derfor et objektivt set færdiglevet liv, men der er ikke noget som tyder på at hans leveår derefter ikke har været gode og meningsfulde.

Den tredje præmis er problematisk fordi den betyder at adgang til dødshjælp alene kommer til at afhænge af dødshjælpsønskets forståelighed udtrykt gennem en personlig beslutning. Det betyder at systemiske

7 https://uk.reuters.com/article/uk-soccer-kenya-suicide/kenyan-fan-commits-suicide-afterman-utds-loss-to-newcastle-idUKBRE9B8oH320131209 
samfundsmæssige effekter af at tillade adgang til dødshjælp bliver irrelevante per definition.

\section{Alder og begrundelse - en lidelsesfuld alderdom}

En anden mulig begrundelse for at gøre det muligt at få dødshjælp på begæring for de ældre er at de ældres liv er mere lidelsesfuldt eller indeholder mindre velfærd end de yngres. Adgang til dødshjælp giver de ældre adgang til at undgå lidelser. Denne begrundelse passer fint med aldring set som et forfaldsnarrativ og med bioetikkens implicitte antropologi hvor den paradigmatisk handlende person er en voksen person på toppen af sin kropslige og kognitive formåen (Holm, 2013; 2017). Hvis vi opfatter aldring som en stadigt nedadgående kurve i funktion, evner og muligheder ligger det lige for at hævde at de ældre skal have mulighed for at stoppe dette forfald, før det går for vidt. Men begrundelsen er stærkt problematisk. For det første er det tvivlsomt om det at give adgang til dødshjælp er den bedste måde at møde et medmenneske som lider på (se kap. 5 og 10). ${ }^{8}$ For det andet kan man også have et meget lidelsesfuldt liv som ung, så hvis stor lidelse er den egentlige, underliggende begrundelse for at give adgang til dødshjælp hænger det ikke godt sammen med et rent alderskriterie.

For det tredje, og måske vigtigst for analysen i dette kapitel, er forfaldsnarrativet simpelthen ikke sandt. De ældre har gode liv, fyldt med velfærd. En 75-årig mand i Danmark har en gennemsnitlig restlevetid på 10,84 år og en 75-årig kvinde kan forvente at leve 12,78 år i gennemsnit; og de som bliver 90 har stadig en ikke ubetydelig restlevetid på 3,73 år for mænd og 4,56 år for kvinder. Disse leveår er også for de fleste gode og meningsfulde leveår. Danmarks Statistik gennemførte i

8 Som jeg har påpeget andetsteds synes N. F. S. Grundtvig at have en bedre forståelse af hvad der er nødvendigt i vers 5 af salmen »At sige verden ret farvel«:

\footnotetext{
»Kom i den sidste nattevagt

i en af mine kæres dragt, og sæt dig ved min side, og tal med mig, som ven med ven, om, hvor vi snart skal ses igen og glemme al vor kvide! «
} 
2015 en landsdækkende, repræsentativ livskvalitetsundersøgelse hvor et af spørgsmålene var »Alt i alt, hvor tilfreds er du med dit liv for tiden?« målt på en 11-trins Likert-skala fra o »slet ikke tilfreds« til 10 »fuldt ud tilfreds«. Aldersgruppen over 70 havde den højeste middeltilfredshed med en score på 7,9 og aldersgruppen 40-59 år den laveste med en score på 7,2; den ældste gruppe havde også den højeste score 8,2 på spørgsmålet »I hvilken grad føler du, at de ting, du foretager dig i dit liv, giver mening?«; og $79,7 \%$ af respondenterne over 70 vurderede at de havde et godt eller meget godt helbred. Helbredsvurderingen var lidt lavere end i gruppen 60-69 år, men lidt højere end blandt de 50-59 årige (Danmarks Statistik).

Vi har derfor ikke grund til at tro at de ældre lider meget mere eller har meget mindre livskvalitet end de yngre, og ingen grund til at tro at dødshjælp er den bedste måde at hjælpe de ældre som rent faktisk lider. Så lidelsesargumentet begrunder ikke at bruge høj alder som kriterium for adgang til dødshjælp.

\section{Er et alderskriterium udtryk for aldersdiskrimination?}

Man må antage at de som fremsætter lovforslag om lovliggørelse af dødshjælp, eller yderligere lovliggørelse i den hollandske kontekst, anser adgang til dødshjælp som et vigtigt gode. De må mene at hvis man er træt af livet og virkelig ønsker at dø, så er det godt at man kan få sit ønske opfyldt ved hjælp af legaliseret dødshjælp. Men hvis det er tilfældet rejser det spørgsmålet om et rent alderskriterium kan opretholdes eller om det er et udtryk for mulig illegitim aldersdiskrimination mod de yngre. Er det ikke, forudsat at adgang til dødshjælp er et vigtigt gode, aldersdiskrimination at en person som er 75 år gammel kan få dødshjælp mens en som er 74 år og 11 måneder gammel ikke kan få det (osv. måned for måned i et sorites argument indtil vi når til myndighedsalderen eller den laveste alder hvor det er plausibelt at et barn har faktisk kompetence til at samtykke?) ${ }^{9}$ Dette er et vigtigt spørgsmål fordi 1) direkte aldersdiskrimination i

9 Sorites argumenter bygger på at konklusionen af det første argument er præmissen for det næste argument i en uendelig række, hvor man ikke kan stoppe hvis man accepterer det første argument. 
mange lande er ulovlig og 2) det er almindeligt antaget at lovgivning som giver adgang til vigtige goder kun kan anvende rene alderskriterier hvis der kan gives en god begrundelse. Hvis der ikke er en god begrundelse for at sætte en aldersgrænse for adgang til dødshjælp vil grænsen blive anfægtet og komme under stadigt juridisk og politisk pres.

Som vi har set ovenfor er det vanskeligt at finde en god begrundelse for at netop de ældre skal have adgang til dødshjælp. Man kan være træt af livet, mene at ens liv er levet færdigt, eller hævde at livet er meningsløst eller lidelsesfuldt helt uafhængigt af alder. De argumenter som kan vise at disse hævdelser ikke er tilstrækkelige til at begrunde et ønske om dødshjælp og/eller vise at de ikke er tilstrækkelige til at give adgang til dødshjælp eller legalisere dødshjælp, er også aldersuafhængige. Der synes derfor ikke at være noget godt argument for en aldersgrænse og den foreslåede grænse forekommer at være fuldstændig arbitrær. I nogle sammenhænge kan arbitrære grænser begrundes. Vi kan for eksempel have gode argumenter for at der bør være en hastighedsgrænse for bilkørsel i bymæssig bebyggelse, men ikke noget argument som siger præcist hvor den grænse bør være. Vi har måske argumenter for at grænsen bør være over $30 \mathrm{~km} / \mathrm{t}$ og under $60 \mathrm{~km} / \mathrm{t}$. I sådanne tilfælde kan vi begrunde at vælge en arbitrær grænse som er let at huske og let at se på bilens speedometer. Så udfra den logik er $50 \mathrm{~km} / \mathrm{t}$ en bedre grænse end 48,7 km/t, og det er fuldstændig acceptabelt for lovgiver at sætte hastighedsgrænsen ved $50 \mathrm{~km} / \mathrm{t}$ selvom dette er et arbitrært tal. Men adgang til dødshjælp på begæring for de ældre er ikke analogt til eksemplet med hastighedsgrænser, fordi vi her simpelthen mangler et godt argument for at der er en relevant forskel mellem de yngre og de ældre. Spørgsmålet er derfor ikke om hvor i intervallet fra 50 til 90 år vi skal sætte grænsen, men om en sådan grænse overhovedet giver mening. Det betyder at et alderskriterium i denne sammenhæng altid vil være en juridisk og politisk svag konstruktion.

På den anden side kan lovliggørelse af dødshjælp på begæring for de ældre også opfattes som en form for diskrimination mod dem. En af grundene til at vi forbyder hjælp til selvmord er at vi ved 1) at mange af dem som fremsætter et selvmordsønske ikke ønsker at dø, men ønsker andre former for hjælp, og 2) at mange af dem som har et selvmordsønske 
nu, senere vil være glade for at de ikke begik selvmord. Vi har derfor gode grunde til ikke at gøre det let at omsætte et selvmordsønske til et selvmord, fordi et selvmord er en irreversibel handling som ikke kan gøres om. Lovliggørelse af dødshjælp til de ældre fjerner denne beskyttelse af dem, men ikke af de yngre.

\section{Alder, dødshjælp og pligten til ikke at ligge sin familie til last}

I litteraturen om dødshjælp nævnes det en gang imellem at der er mange primitive samfund hvor ældre og svagelige personer selv vælger at trække sig tilbage fra samfundet med det eksplicitte formål at dø så de ikke længere er en byrde for familien, eller hvor ældre udsættes for mere eller mindre frivillig dødshjælp (se f.eks. Chatterjee, 2014 om forholdene i den indiske delstat Tamil Nadu). Den danske skønlitterære forfatter Martin A. Hansen beskriver i sin historiske roman Orm og Tyr en lignende, angiveligt norrøn praksis hvor den ældste søn var forpligtet til at slå sine forældre ihjel når de blev så gamle at de lå familien til last: »Man slog dem med en ættekølle, en sådan gemmes i Sverige endnu. Den gik i arv. Den gamle bad sønnen gøre det«. Ættekøllen og ættestupet hvorfra den gamle angiveligt blev skubbet ud findes også omtalt i Vilhelm Mobergs Min Sverigeshistorie. Hvorvidt den praksis som Hansen og Moberg beskriver rent faktisk fandtes i Norden i forhistorisk tid er stærkt omstridt. Men både standardeksemplerne fra dødshjælpslitteraturen og den måske mytiske ættekølle peger på en idé om at de gamle kan have en pligt til ikke at ligge familien til last, og at denne pligt kan medføre en pligt til at søge dødshjælp.

En sådan pligt bliver også diskuteret i den akademiske litteratur, specielt i USA hvor fraværet af et godt offentligt sundhedssystem medfører at alvorlig sygdom eller kronisk plejebehov hurtigt kan drive en familie til tiggerstaven (Hardwig, 1997). I europæisk kontekst er en pligt til at dø blevet støttet af den kendte engelske moralfilosof Mary Warnock (Warnock, 2008).

Lovliggørelse af dødshjælp med alder som eneste kriterium vil gøre dødshjælp tilgængelig for de ældre som virkelig, genuint ønsker 
dødshjælp, men vil på samme tid også gøre dødshjælp til en valgmulighed for de ældre som ikke ønsker det. Lovliggørelse vil ændre både hvad det er rationelt at gøre og hvad der opfattes som rationelt at gøre, og vil i nogle tilfælde gøre at valget af dødshjælp ser mere rationelt ud for den enkelte. Dette er ikke et glidebaneargument, men den simple observation at en handlings rationalitet, blandt mange andre ting, afhænger af om der er negative juridiske konsekvenser ved at udføre handlingen. Vi forbyder handlinger for at gøre det mindre plausibelt at udføre dem, og når vi ophæver forbudene ændrer det den rationelle afvejning. I forbindelse med dødshjælp betyder det at det nu kan blive rationelt at vælge dødshjælp i nogle sammenhænge hvor det ikke var rationelt før. Og, måske endnu mere vigtigt, at det bliver muligt for andre at påpege denne »rationalitet«. Mediediskussioner om »ældrebyrden« og alle de problemer den medfører for samfundet og de yngre generationer kan nu sammenkædes med muligheden for at få dødshjælp. Og, det bliver pludselig muligt at sige til et gammelt menneske »du gør livet til et mareridt for dine børn og børnebørn. Var det ikke bedre hvis du søgte dødshjælp, så de kunne leve deres liv igen. Hvis du var et godt menneske ville du i det mindste overveje dødshjælp«.

Nogle ser ikke dette som et stort problem. Den kendte engelske bioetiker John Harris skriver for eksempel:

Many objectors to medically-assisted death emphasise their concern to protect the vulnerable. I yield to none in my concern for the vulnerable. But there are two groups of vulnerable people to whom we owe concern, respect and protection. One consists of those who might be pressured into requesting death. The others are those, like Tony Nicklinson who are cruelly denied the death they seek. We are surely not entitled to abandon one group of vulnerable people in favour of another. We have somehow to protect both.

Those who might be encouraged to die are and remain free to refuse. They are not victims unless they make themselves victims. Those seeking assisted death are the more vulnerable because they are truly coerced, absolutely prevented from obtaining the remedy they seek. They seek death and are denied it: these are genuinely coerced and are certainly the victims of tyranny. (Harris, 2015, s. 141-2, min fremhævning) 
Men, den frihed til at sige »nej« til dødshjælp som Harris lægger så meget vægt på er stærkt problematisk. Vi ved at ældre ofte føler sig presset til for eksempel at flytte på plejehjem og at de nogle gange føler sig presset til at give penge til familiemedlemmer. I alle disse tilfælde kunne de sige "nej«, men det at de ikke siger nej viser på ingen måde at deres beslutning er frivillig og ikke fremtvunget af familiens eller omgivelsernes pres.

Dette frivillighedsproblem kan opstå i forbindelse med enhver lovliggørelse af dødshjælp, men lovliggørelse alene på grund af alder gør det specielt akut fordi denne form for lovliggørelse signalerer officielt at det at overveje dødshjælp er samfundsmæssigt acceptabelt når man er 75 år gammel eller ældre, for man kunne jo være træt af livet. Hvis man er over 75 år kan man ikke længere forsvare sig ved at hævde at man ikke opfylder kriterierne, og en læge kan ikke længere legitimt spørge ind til begrundelsen for ønsket om dødshjælp. Man behøver ikke at have et ønske om dødshjælp som er begrundet i sygdom og uafhjælpelig lidelse, eller i det hele taget begrundet på nogen måde. Man har en ret til dødshjælp, og det er derfor nok at man har ønsket vedvarende og at man ikke er psykisk syg. Hvordan ønsket er opstået og vedligeholdt er også irrelevant, så længe det formelt set er frivilligt og ikke tvungent.

Frivillighedsproblemet er derfor langt mere reelt og problematisk for denne type af lovliggørelse af dødshjælp end for mange andre typer, fordi lovliggørelse med et rent alderskriterium i virkeligheden er lovliggørelse af dødshjælp på begæring for den relevante aldersgruppe.

\section{Konklusion}

At give adgang til dødshjælp alene på grund af et kronologisk alderskriterium kan ikke begrundes filosofisk eller juridisk, og vil, forudsat at adgang til dødshjælp opfattes som et gode være en form for diskriminering mod dem der er yngre end den fastsatte aldersgrænse.

Det er derudover udtryk for en fejlagtig og diskriminerende opfattelse af aldring og de ældre som dømt til uafvendeligt tab og lidelse, hvis de ikke kan få lov til at »befri« sig selv ved hjælp af dødshjælp.

At tillade dødshjælp på begæring for en bestemt gruppe vil ydermere betyde at medlemmer af denne gruppe kan blive sat under pres af familie 
eller andre til »frivilligt« at søge dødshjælp, og at dette pres vil være langt vanskeligere at modstå end hvis dødshjælp kun kan foretages når der er en kombination af en objektivt set svært lidelsesfuld tilstand som giver adgang til dødshjælp og et ønske om dødshjælp.

Selv de som mener at vi skal lovliggøre dødshjælp til personer med svære lidelser i livets slutfase og som har et ønske om dødshjælp, bør derfor være modstandere af at lovliggøre dødshjælp på begæring alene begrundet i et alderskriterium. For de som mener at alle kompetente personer som ønsker dødshjælp skal have ret til dødshjælp, kan lovliggørelse af dødshjælp for de ældre kun være et trin på vejen til den endelige sejr, dødshjælp på begæring for alle; og de kan kun, hvis de er ærlige, se dette trin som et tidsbegrænset kompromis som de ikke har tænkt sig skal holde i fremtiden (se også Holm, 2010).

\section{Referencer}

Callahan, D. (1995). Setting limits: Medical goals in an aging society with "a response to my critics «. Georgetown University Press: Washington D.C.

Chatterjee, P. (2014). Thalaikoothal: The practice of euthanasia in the name of custom. European Researcher, 87(11-12), 2005-2012.

Danmarks Statistik. Statistikbanken - Levevilkår. www.statistikbanken.dk

Hansen, M. A. (1952). Orm og tyr. Wivels Forlag: København.

Hardwig, J. (1997). Is there a duty to die? Hastings Center Report, 27(2), 34-42.

Harris, J. (2015). Cancelling our captivity. I C. Brewer \& M. Irwin (Red.), »'ll see myself out, thank you - Thirty personal views in support of assisted suicide (s. 139-144). Newbould on Stour: Skyscraper Publications.

Holm, S. (2010). Euthanasia: Agreeing to disagree? Medicine, Health Care and Philosophy, 13(4), 399-402.

Holm, S. (2013). The implicit anthropology of bioethics and the problem of the aging person. I M. Schermer \& W. Pinxten (Red.), Ethics, health policy and (anti-)aging: Mixed blessings (s. 59-71). Dordrecht: Springer.

Holm, S. (2015). The debate about physician assistance in dying: 40 years of unrivalled progress in medical ethics? Journal of Medical ethics, 41(1), 40-43.

Holm, S. (2017). Not growing old - gracefully. I M. Schweda, L. Pfaller, K. Brauer, F. Adloff \& S. Schicktanz (Red.), Planning later life: Bioethics and public health in ageing societies (s. 119-131). London: Routledge.

Moberg, V. (1971). Min Sverigeshistorie fortalt for folket. Schønbergs Forlag: København 
Van Wijngaarden, E., Klink, A., Leget, C. \& The, A-M. (2017). Assisted dying for healthy older people: A step too far? BMJ, 357, j2298.

Warnock, M. (2008). A duty to die? Omsorg, 25(4), 3-5.

Williams, A. (1997). Intergenerational equity: An exploration of the "fair innings" argument. Health Economics, 6(2), 117-132.

\section{Ordforklaringer}

fotboldhold: fotbollsklubb (S), fotballag (N)

måle: mäta $(S)$

pålidelig: pålitlig $(\mathrm{S})$

sundhedsminister: hälsominister $(\mathrm{S})$, helseminister $(\mathrm{N})$

tidsligt: tidsenlig $(\mathrm{S})$, tidsmessig $(\mathrm{N})$

yndling: favorit (S) 

Del IV

Politikk 



\title{
Erfarenheter från femtio år med dödshjälp i Nederländerna
}

\author{
Theo A. Boer
}

Protestantse Theologische Universiteit, Groningen

\begin{abstract}
Worldwide the Netherlands has the broadest experience with organising euthanasia and assisted suicide. Roughly, three phases may be distinguished: in 1968-1985 euthanasia was vividly debated but, as it was illegal, it was at best tolerated. Since 1985, beginning with a verdict of the Supreme Court, euthanasia became officially tolerated and legalised in two steps in 1994 and 2002, respectively. The numbers then stabilised until 2006. The onset of the third phase was in 2007. Since that year, the numbers tripled, new pathologies were accepted as a reason for euthanasia, the number of people with a long life-expectancy increased, and mobile euthanising teams were established that provide euthanasia without a prior doctor-patient relationship. These developments were made possible by a combination of cultural developments, the absence of restrictive legal norms, and the almost unlimited mandate of the Review Committees.
\end{abstract}

Keywords: assisted dying, cultural development, euthanasia, the Netherlands, review committees

\section{Dödshjälp under åren 1968-2006'}

Decennier av diskussioner föregick legaliseringen av dödshjälp i Nederländerna år 2002. År 1968 initierade psykiatern J. H. van den Berg diskussionen genom sin bok Medische macht en medische ethiek (Medicinsk

1 Detta bidrag är en utvidgad och uppdaterad version av Boer, 2018. Godkänd för användning av förlaget Taylor \& Francis. Sedan det här kapitlet utgivits den 13 maj 2020 har det uppdaterats med några mindre, språkliga revideringar.

Sitering av denne artikkelen: Boer, T. A. (2020). Erfarenheter från femtio år med dödshjälp i Nederländerna. I M. A. Horn, D. J. H. Kleiven \& M. Magelssen (Red.), Dødshjelp i Norden? Etikk, klinikk og politikk (Kap. 13, s. 251-273). Oslo: Cappelen Damm Akademisk. https://doi.org/10.23865/noasp.96.ch13. Lisens: CC BY 4.o. 
makt och medicinsketik) (van den Berg, 1968). Genom att använda grafiska illustrationer över allvarligt och onödigt lidande resonerade författaren kring det faktum att en sjukvård som har gjort så betydande framsteg med att förlänga liv även borde ha modet att kunna avsluta liv. År 1972 grundades Nederländska föreningen för frivillig eutanasi (NVVE) som snart blev världens största organisation i sitt slag. Ännu ett decennium av diskussioner följde därefter med en omfattande »under-the-radar»-praxis. År 1984, i Schoonheim-domen, frikände högsta domstolen en läkare som hade utfört dödshjälp. Domstolens motivering var att läkaren befann sig i en förpliktelsekonflikt och agerade i enlighet med riktlinjer som fastställts av Kungliga nederländska läkarförbundet KNMG (Weyers, 2002; Thomas, 1984; Gevers, 1996). År 1985 resulterade en rapport utförd av »Statens Eutanasieutskott» i ett avtal mellan KNMG, hälsovårdsministeriet och allmän åklagare: en läkare som utförde dödshjälp och rapporterade detta till allmän åklagare skulle inte bli åtalad om särskilda villkor uppfylldes (Staatscommissie Euthanasie, 1985). Begreppet »dödshjälp (eutanasi)» innebar från och med nu uteslutande dödshjälp på begäran av patienten.

År 1994 fick befintlig praxis en första juridisk bas i form av ett tillägg till den nederländska begravningslagen. Inom ramen för denna lagstiftning var dödshjälp fortfarande straffbar, men väl rapporterad till en allmän åklagare väcktes inte åtal om följande villkor uppfylldes:

a. läkaren var övertygad om att patienten hade gjort en frivillig och väl övervägd begäran;

b. läkaren var övertygad om att patientens lidande var outhärdligt och att det inte fanns någon utsikt till förbättring;

c. läkaren hade informerat patienten om aktuell situation och prognos;

d. läkaren hade kommit fram till slutsatsen, tillsammans med patienten, att det inte fanns något rimligt alternativ mot bakgrund av patientens situation;

e. läkaren hade konsulterat minst en annan oberoende läkare, som måste ha träffat patienten och gett ett skriftligt utlåtande gällande tillbörligt vårdkriterium, som hänvisas till i punkt a till d ovan; 
f. läkaren hade avslutat patientens liv eller tillhandahållit självmordshjälp med tillbörlig medicinsk vård och omsorg.

Allmän åklagare skulle bedöma varje enskilt fall i efterhand. Endast efter det att allmän åklagare slagit fast att kriteriet hade uppfyllts kunde en läkare vara säker på att det inte skulle väckas något åtal. Med hänsyn till det stora antalet fall av dödshjälp, behovet av specialistkompetens gällande bedömning av rapporter och en utbredd allmän önskan om att avkriminalisera proceduren fattade regeringen 1998 ett beslut om att det mesta av åklagarens arbetsuppgift skulle övertas av fem regionala kontrollkommissioner (RKK), bestående av en advokat, en läkare och en etiker. RKK-instanserna tog fram ett utkast till beslut till åklagaren, som hade ansvar att fatta det slutgiltiga beslutet.

Det bör noteras att ytterligare några potentiella kriterier som debatterades under åren inte inkluderades: en varaktig patient-läkarrelation; att patienten själv skulle administrera det dödliga läkemedlet; att en patient skall vara helt beslutsför och vid medvetande när dödshjälpen utförs; att närstående skall underrättas och/eller konsulteras innan dödshjälp utförs; att patientens begäran skall vara bestående; att den behandlande läkaren skall kunna tillhandahålla alternativa möjligheter, om tillämpligt, och inte endast dödshjälp; att patienten måste ha lidit av en medicinskt klassificerbar sjukdom och, kanske viktigast av allt, att en oundviklig naturlig död förväntades inom en överskådlig framtid. Alla andra jurisdiktioner utanför Beneluxländerna som legaliserade dödshjälp - delstater i USA, Victoria (Australien), Kanada, Colombia - inkluderade en »förutsägbar död» som kriterium. Även om ytterligare kriterier såsom dessa inte inkluderades, fungerade många av dem som »bakgrundskriterier» i granskningsproceduren under minst ett decennium efter 1994. Detta gäller i synnerhet kriteriet rörande »förutsägbar död», patient-läkarrelation, beslutskompetens, varaktig begäran, alternativa åtgärder och fysisk sjukdom. Om något av dessa villkor inte uppfylldes, kunde en rapporterande läkare nästan vara säker på att en RKK skulle vara kritisk och ställa ytterligare frågor. Under 1990-talet var dödshjälp rättfärdigat av många på basis av att det var nödvändigt i syfte att förebygga en plågsam död. Vi kan hänvisa till dessa fall som 
»traditionella eutanasifall». I tider när palliativ vård i Nederländerna endast utvecklats till viss del kunde många stödja möjligheten att ge en patient dödshjälp, på patientens begäran, i syfte att avsluta en plågsam dödskamp som i hög grad även skulle traumatisera anhöriga och andra personer.

År 2002 instiftades det andra och slutgiltiga arrangemanget i form av en separat lagstiftning "Termination of Life on Request and Assisted Suicide (Review Procedures) Act» (hädanefter kallad eutanasilagen) (Weyers, 2002). De viktigaste elementen i denna lagstiftning är att granskningskommittéernas ansvarsområde och uppgift blev juridiskt bindande istället för rådgivande. Genom att man placerade åklagaren på avstånd trodde man att den rapporterande proceduren skulle bli mindre stressande för läkare.

Eutanasilagen utgör exempel på nederländsk pragmatism som även ligger till grund för andra liberala lagar (såsom de lagar som reglerar homosexuellas rättigheter, lätt narkotika och prostitution). Hellre än att lämna viss praxis under radarn tror nederländarna på procedurer baserade på transparens, genomförbarhet och kompromiss. Precis som i överenskommelser 1985, 1994 och 1998 förblev eutanasi ett brott och kan straffas med fängelse på upp till tolv år. På sätt och vis är den nederländska eutanasilagen därför en paradox. Eutanasi är legaliserat, dock endast i efterhand - efter det att en RKK har granskat och godkänt det - och aldrig i förväg. Det kan aldrig bli ett professionellt åtagande, en läkare har inte ens skyldighet att hänvisa en patient till en kollega som skulle kunna åta sig att utföra dödshjälp. I syfte att hindra denna lagstiftning från att bli verkningslös har en omfattande granskningsapparat inrättats som involverar 45 RKK-medlemmar (jurister, läkare och etiker) och två dussin sekreterare och tjänstemän. Årsrapporter erbjuder statistik på nederländska och engelska gällande antalet eutanasifall, specialiteter hos läkare som utför dödshjälp samt patientens diagnos, förstärkt med fallbeskrivningar om banbrytande dödshjälpsfall och dödshjälpsfall som inte uppfyller kriterierna. De flesta RKK-domar finns tillgängliga online i anonym form. Femårsanalyser har publicerats sedan 1991 (van der Maas, van Delden, van der Wal \& Pijnenborg, 1991; van der Wal \& van der Maas, 1996; van der Wal, van der Heide, Onwuteaka-Philipsen 
\& van der Maas, 2003; Onwuteaka-Philipsen, Gevers, van der Heide \& van Delden, 2007; van der Heide, Legemaate, Onwuteaka-Philipsen, Bolt \& van Delden, 2012; Onwuteaka-Philipsen, Legemaate, van der Heide \& van Delden, 2017). Noggrannheten som kringgärdar administrationen av dödshjälp visar att de nederländska lagstiftarna är medvetna om vilken mycket speciell handling eutanasi är.

Instiftandet av eutanasilagen år 2002 blev början på en relativt lugn period, hjälpt av resultatet från en statlig utvärdering samma år som visade att antalet fall av dödshjälp legat på en stabil nivå under några år (van der Wal et al., 2003). År 2003 gjorde den ledande nederländska dagstidningen NRC Handelsblad en intervju med Gerrit van der Wal och Paul van der Maas, som båda varit involverade i tre statliga utvärderingar (Oostveen, 2003).

F: $\quad$ Vilket var det mest överraskande utvärderingsresultatet för Er?

Van der Maas: Att antalet fall av eutanasi och assisterat självmord stabiliseras. F: Befinner sig nu inte Nederländerna på det internationellt fruktade sluttande planet?

Van der Maas: Nej. Trots det faktum att vi hade förutspått en viss ökning.

Van der Wal: $\quad$ Det var på grund av att behovet av kontrollerad dödshjälp även fastställs med hänsyn till kulturella förhållanden. Efter vår tidigare utredning, för 6 år sedan, förväntade vi oss att behovet av eutanasi skulle öka på grund av att en ny, mer självsäker generation blir äldre. Detta påvisas inte i insamlade data.

F: $\quad$ Sedan 1995 är antalet fall av eutanasi de facto uppenbarligen oförändrat. Vad innebär det?

Van der Maas: Detta kan innebära att antalet fall av eutanasi inte kommer att ändras under de kommande åren. Jag förväntar mig faktiskt det. Att detta är ungefär det behov vi har av eutanasi i Nederländerna.

Nästa utvärdering, baserad på data från 2005 och publicerad 2007, bekräftar och styrker dessa undersökningsresultat. Siffrorna låg kvar på en stabil nivå och en betydande ökning när det gäller rapporteringsvilja noterades (Onwuteaka-Philipsen et al., 2007). Inte endast eutanasiförespråkare utan även skeptiker var imponerade över dessa 
undersökningsresultat. Vid internationella utbyten drog många slutsatsen att andra länder skulle kunna ha nytta av att ta efter exemplet med det nederländska experimentet.

\section{Utvecklingen under åren 2007-2018}

Efter denna initiala stabilisering inträffade några viktiga ändringar: en ökning av antalet dödshjälpsfall, en expansion gällande diagnoser en ökning gällande förväntad livslängd och förekomst av eutanasi utan en föregående patient-läkarrelation. Jag kommer att lyfta fram dessa förändringar med mina personliga erfarenheter i åtanke: under perioden 2005-2014 var jag medlem i en RKK och granskade nästan 4 ooo dödshjälpsfall. I mer än 3700 fall gjorde jag anonyma anteckningar gällande ålder, sjukdom, förväntad livslängd etc. och, dessutom, etiskt betydande element. På det sättet kunde jag följa utvecklingen nära. Tyvärr är dock publiceringen av dessa data förbjuden.

\subsection{Antalet dödshjälpsfall}

Från och med kring år 2007 återupptog siffrorna sin uppåtgående trend: från 1923 år 2005 till 6126 år 2018, vilket är en ökning på 219 \% (Regionale toetsingscommissies euthanasie, 2019). Anonyma statliga uppskattningar signalerade en liknande ökning (från 2425 år 2005 till 6800 år 2015 eller $180 \%$, diagram 1). ${ }^{2}$ En del har i media hävdat att ökningen speglar utvecklingen gällande övergripande dödlighet, men den siffran ökade med endast $12 \%$ under perioden 2005-18 (Centraal Bureau voor de Statistiek, 2019). Inte heller kan ökningen ha blivit förorsakad av en sämre palliativ vård: under de senaste decennierna har betydande framsteg gjorts och gradvis kan den kvalitetsnivå som palliativ vård nu uppnått jämföras med den palliativa vård som återfinns i andra europeiska länder (Lynch, Connor \& Clark, 2013). Enligt den statliga utvärderingen

2 Skillnaden mellan siffrorna i femårsutvärderingarna och de utvärderingar som utförts av kommittéerna kan utgöra en gråzon av fall av dödshjälp som ägde rum, men som inte rapporterats. Denna gråzon har även utökats: från 493 fall under 2005 till 1284 under 2015. 
från 2007 (baserad på data från 2005) förorsakades minskningen av antalet fall av dödshjälp av förbättringar inom palliativ vård (Onwuteaka-Philipsen et al., 2007). Intressant att notera, som kan ses nedan, är att siffrorna visar en plötslig minskning under 2018. Det återstår att se huruvida denna minskning är indikativ för en omsvängningstendens eller om den skall förklaras i form av »en variation i siffrorna» som Jacob Kohnstamm, koordinerande ordförande för RKK-instanserna, föreslog $\mathrm{i}$ samband med presentationen av siffrorna för 2018 (DeJong, 2019). Kohnstamm pekade på det faktum att siffrorna under de första månaderna 2019 återtog sin uppåtgående trend och visar en ökning på 9 \% jämfört med 2018.

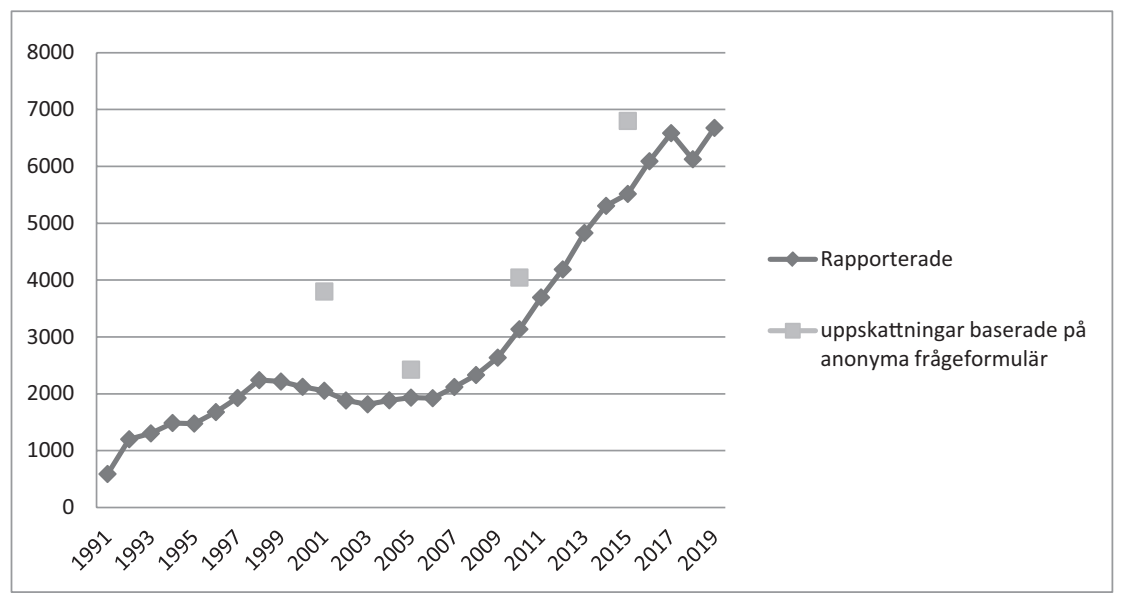

Diagram 1. Rapporterade dödshjälpsfall 1991-2018. 2019: uppskattning

Den statliga utvärderingen 2017 kunde fastställa att under 2015 var 4,5\% av alla dödsfall i Nederländerna en följd av eutanasi. Urbana och mer sekulariserade regioner har ett högre antal och antyder att antalet kan komma att fortsätta stiga: i provinsen Noord-Holland, vars största stad är den nederländska huvudstaden Amsterdam, står eutanasi för 7,3\% av alla dödsfall, där en begäran om eutanasi har inlämnats i 11,9 \% av alla dödsfall (Onwuteaka-Philipsen, 2017). I vissa områden står eutanasi för $14 \%$ av alla dödsfall (Boer \& Groenewoud, 2020). Tillsammans med eutanasi är även palliativ sedering på uppgång och stod för 17,6 \% av alla dödsfall under 2016 (Onwuteaka-Philipsen et al., 2017; Stichting 
Farmaceutische Kengetallen, 2017). Medicinsk inflytande på när och hur man dör i Nederländerna är förmodligen större nu än den någonsin varit tidigare. Utvärderingen rekommenderar forskning gällande orsaker av ökat antal fall av dödshjälp och gällande praxis för palliativ sedering (Onwuteaka-Philipsen et al., 2017). ${ }^{3}$

\subsection{Patologi}

Under de första åren av nederländsk eutanasipraxis ägde merparten av dödshjälpsfallen rum i en kontext med obotlig sjukdom (cancer, AIDS, progressiva neurologiska sjukdomar), dagar eller veckor innan en naturlig död skulle ha inträffat och med patientens familjeläkare som utförde dödshjälpen. Dessa fall, som i granskningsproceduren ofta kallades "traditionella eutanasifall», uppvisar starka likheter med den dödshjälp som numera diskuteras i olika länder runt om i världen. Som kan ses i diagrammen $2 \mathrm{a}$ och $2 \mathrm{~b}$ har nu nederländarna gått in $\mathrm{i}$ en annorlunda fas, i vilken den relativt största ökningen avseende dödshjälp är för icke-cancerpatienter:

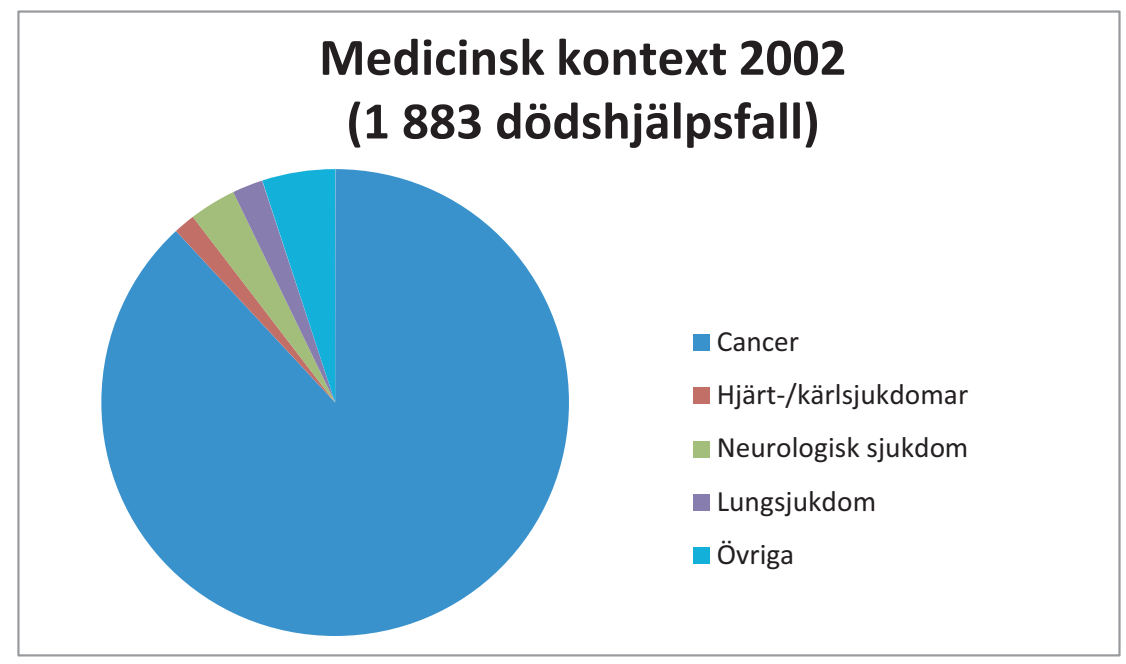

3 Givet likheterna mellan eutanasi och palliativ sedering förespråkar ordförande Wim Distelmans i Belgian Federal Control and Evaluation Commission en rapporterande procedur för palliativ sedering som skulle vara likartad den som krävs för eutanasi (Distelmans, 2017). 


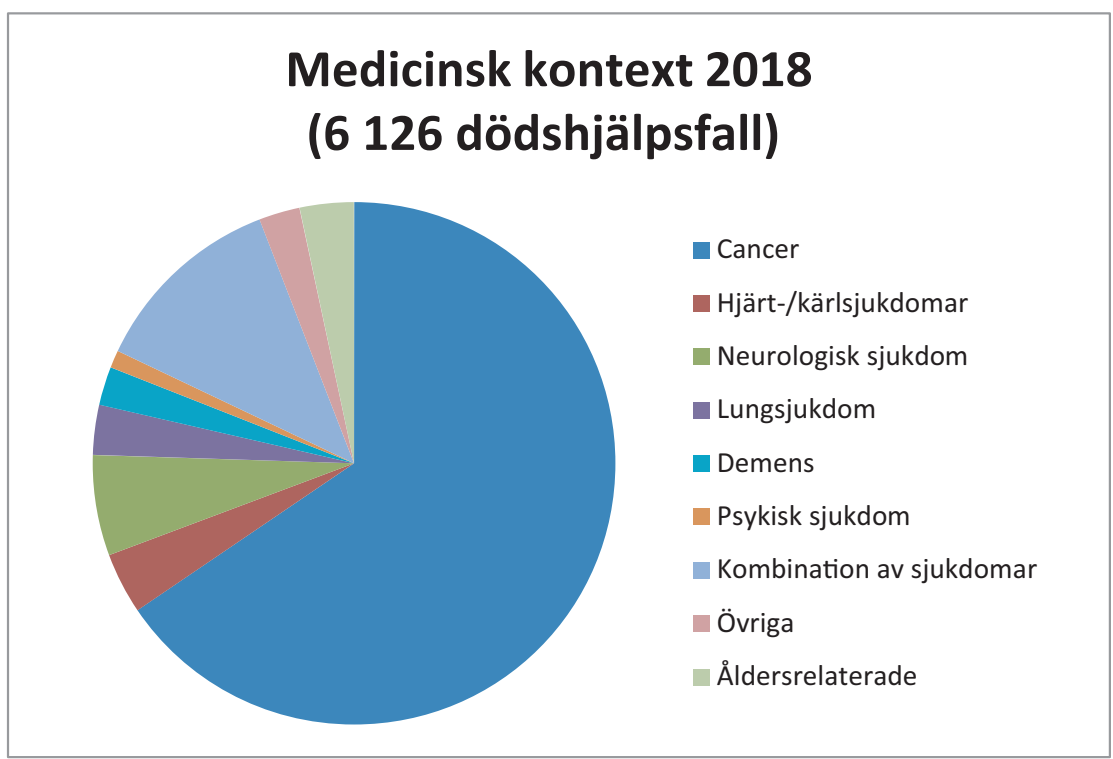

Diagram 2a och 2b. Medicinsk patologi som ligger till grund för dödshjälp i Nederländerna, 2002 och $2018 .{ }^{4}$ Kategori »övriga» under år 2002 kan inkludera tillfälliga fall av psykisk ohälsa och demens.

\subsection{Förväntad livslängd}

Traditionella eutanasifall utgjorde största delen av rapporterna fram till år 2007. Kontexten för allmänt godkännande av eutanasi under pionjäråren var övertygelsen att eutanasi ibland kan vara ett försvarbart alternativ för patienter vars naturliga död förväntas inträffa inom några dagar eller veckor. Det fanns dock några märkbara undantag. Ett antal domslut och rättsliga avgöranden sedan 1970-talet, i synnerhet Wertheim-, Schoonheim- och Chabot-fallen, gällde patienter vars naturliga och oundvikliga död rimligen inte var förutsägbara (Weyers, 2002). Under 1985 diskuterade de två största protestantiska kyrkosamfunden, med empati, förekomsten av en »psykologisk slutfas» (Samen op Weg Kerken, 1998; Boer, 2016).5 Och även om några lokala riktlinjer kan ha

4 Antalet dödshjälpsfall under 2002: cancer 1658 , hjärt-/kärlsjukdomar 28, neurologisk sjukdom 61, lungsjukdom 40, övriga (inklusive tillfälliga fall av psykisk sjukdom och demens 95). Under 2018: cancer 4 013, hjärt-/kärlsjukdomar 231, neurologiska sjukdomar 382, lungsjukdom 189, demens 146, psykisk sjukdom 67, kombination av sjukdomar 738, övriga 155 och åldersrelaterade 205.

5 Nederländsk kalvinistisk protestantism har förmodligen bidragit på ett betydelsefullt sätt när det gäller acceptansen av eutanasi (Boer, 2016). 
varit olika (exempelvis vid sjukhus), så var en förutsägbar död aldrig en del av de nationella riktlinjerna. När det gäller de sällsynta undantag där en patient inte var nära en naturlig död fanns det ett brett, allmänt delat förtroende för att läkare skulle agera med måttfullhet och återhållsamhet. Såsom nämnts tidigare fungerade en förutsägbar död som ett bakgrundskriterium i granskningsproceduren: varken officiell eller avgörande, men icke desto mindre viktig för analys och bedömning av en rapport. Om en eutanasipatient väntades ha längre tid än några månader att leva, fanns det en rimlig chans att en RKK skulle ställa ytterligare frågor.

Från omkring år 2007 och framåt blev det tydligt att det skett en svängning när det gäller förväntad livslängd hos personer som fick dödshjälp. I den statliga femårsutvärderingen 1991 uppskattade man att av alla dem som fick dödshjälp år 199o hade 1 \% mer än ett halvt år kvar att leva (van der Maas et al., 1991; Boer, 2017a). Tjugofem år senare hade denna procentandel ökat till $8 \%$. I absoluta tal innebar detta en ökning från 27 till 544 patienter per år.

\subsection{Mobila eutanasiteam}

Traditionellt sett var en långvarig patient-läkarrelation ett avgörande element i nederländsk eutanasipraxis; det ansågs allmänt vara en av garanterna för en omsorgsfull praxis. Skuggsidan av systemet med familjeläkare är att några patienter med en eutanasibegäran relativt sent kommer att få reda på att deras ordinarie läkare inte kommer att tillhandahålla dödshjälp på grund av professionella, emotionella eller religiösa skäl. ${ }^{6}$ Andra läkare kanske inte har något emot eutanasi per se, men vägrar att utföra handlingen för denna patient i denna särskilda situation: vissa fall är ovanligt komplexa, en del läkare befarar svårigheter i granskningsproceduren, en del vill endast ge dödshjälp till patienter som har en obotlig sjukdom och andra tycker att patientens lidande inte är outhärdligt

6 Utvärderingen 2017 visade att procentandelen läkare som aldrig vill ge dödshjälp till en patient har ökat från 11 \% år 2001 till 19 \% år 2016 (Onwuteaka-Philipsen et al., 2017). Denna uppgift inkluderar inte psykiatrer. Av psykiatrer indikerar en majoritet på $63 \%$ att de aldrig kommer att utföra eutanasi, en ökning från 53 \% år 1995 (ibid.). 
eller hopplöst. Utifrån omtanke om patienter som nekats dödshjälp av sina egna läkare grundade den nederländska dödshjälpsorganisationen NVVE den så kallade »Levenseindekliniek» (Dödshjälpskliniken) i Haag. Initialt finansierades kliniken genom donationer, men sedan dess har det genererats tillräckligt med intäkter från försäkringsbolag för att täcka klinikens kostnader.

Kliniken slog upp dörrarna i början av 2012. Den omfattar en byggnad men är inte en klinik tekniskt sett: den består av ett nätverk av mobila team som besöker patienter i deras hem eller i deras sjukinrättningar och som utför dödshjälp på plats. Klinikens team - mer än 50 team som består av en läkare och en sjuksköterska - arbetar rikstäckande. Ett team träffar en patient minst en gång innan man fattar ett »go»- eller »no-go»beslut. Därefter följer normalt ytterligare ett eller två möten. Det faktum att dessa patient-läkarrelationer kan vara intensiva och laddade förändrar inte det faktum att en dödsönskan bildar enda bas för denna relation. Dessa läkare accepterar för det mesta andra läkares diagnos och föreslår ibland behandling, men deras huvudsakliga uppgift är att besluta om och potentiellt utföra dödshjälp, på patientens begäran. Kliniken har vare sig finansiering eller expertis för att kunna erbjuda någon form av behandling. Under de senaste åren har klinikens läkare även tillhandahållit expertis och support till patientens egna läkare i en dödshjälpsprocess. Detta verkar vara en herkulisk uppgift eftersom, såsom indikerats, antalet läkare som är beredda att tillhandahålla dödshjälp minskar.

Medan RKK-instanserna under tidiga år skulle ha varit mycket kritiska gällande frånvaron av en patient-läkarrelation och frånvaron av alternativa behandlingsmöjligheter, är dessa två »frånvaro»-förhållanden nu inte längre en grund för RKK-instanserna att underkänna klinikens eutanasifall. Detta innebär alltså att dessa bakgrundskriterier inte längre fungerar. År 2012, när kliniken öppnade, fick 53 patienter dödshjälp. Under 2019 hade denna siffra ökat till 898 patienter (Expertisecentrum euthanasie, 2020). Detta innebär inte att kliniken ger dödshjälp till vem som helst eller hur som helst: 2019 fick den 3122 förfrågningar om eutanasi och var tvungen att avslå $71 \%$ av dessa förfrågningar. Sedan 2018 har kliniken bytt namn till »Expertcentrum eutanasi». 


\subsection{Dödshjälp som ett alternativ till våldsamt självmord?}

Det förs ibland diskussioner om att tillgängligheten av dödshjälp kommer att leda till lägre självmordstal. Det finns en viss intuitiv vädjan i detta argument. Valmöjligheten med eutanasi kan för några patienter vara anledning att avstå från självmord och istället vänta på att en läkare hjälper dem. För många kan valmöjligheten med en "nödutgång» höja deras livskvalitet och några som annars kanske hade tillgripit självmord kan finna mod att fortsätta leva. För dem som är fast beslutna att begå självmord kan dödshjälp dessutom tillhandahålla ett mer fridfullt och lämpligt sätt att dö, ett mer fridfullt avsked och mindre trauma för efterlevande.

Att dödshjälp finns tillgängligt i dessa fall tycks emellertid inte leda till lägre självmordstal. För det första kommer impulsiva självmord fortsätta att inträffa, särskilt med hänsyn till de relativt långa procedurerna kring eutanasi för patienter med en psykiatrisk diagnos. För det andra tycks inte alla patienter med en dödsönskan önska assistans för att avsluta sina liv. En del kanske inte vill få hjälp alls; hos andra patienter (särskilt de som har psykiatriska sjukdomar) »kräver» deras ilska och panik så att säga en dramatisk död snarare än ett fridfullt, organiserat sätt att dö. För det tredje kan valmöjligheten eutanasi för patienter med längre livslängd underminera statliga åtgärder för att förhindra självmord.? För det fjärde kan valmöjligheten eutanasi göra att patienter inte söker behandling: varför skall man gå igenom en lång behandling utan garantier om dess effektivitet medan den mest drastiska lösningen på ens lidande är inom räckhåll (se kap. 11)? För det femte föredras dödshjälp inte av alla anhöriga: i två fall i Belgien har anhöriga till patienter med psykisk ohälsa som fått dödshjälp inkommit med klagomål mot läkare för att ha visat nonchalans och försumlighet i samband med dödshjälp. ${ }^{8}$ Till ett sjätte argument återkommer vi nedan: eutanasi kan bidra till ett kulturellt klimat i vilket dödshjälp figurerar som en lösning på allt svårt lidande.

7 Jfr litteratur om så kallade copy cat- och Werther-effekter.

8 https://www.theguardian.com/world/2018/nov/27/belgium-launches-first-criminal-investigation-of-euthanasia-case; http://www.bioethics.net/2019/o1/mortier-v-belgium-court-reviews-euthanasia-for-psychiatric-suffering/. 
Utöver dessa argument finns det inte heller tunga empiriska bevis som stödjer påståendet att eutanasi leder till färre självmord, åtminstone inte utifrån den nederländska kontexten. Antalet självmord i Nederländerna har ökat avsevärt under det senaste decenniet. I tider när antalet rapporterade fall av dödshjälp som en procentandel av totalt dödstal tredubblades från 1,3 \% under år 2002 till 4,4 \% under 2017 ökade även antalet självmord: från 1567 under år 2002 till 1917 under år 2018, vilket är en ökning på $22,3 \%$. Antalet självmord nådde en relativt låg nivå på 1353 under år 2007; siffrorna för 2018 representerade inte bara en tillväxt på $41,7 \%$ utan nådde också den högsta nivån någonsin. Detta är ännu mer signifikant givet det faktum att eutanasi från år 2009 och framåt började bli tillgänglig för personer med psykisk sjukdom, demens och andra kroniska sjukdomar, såsom beskrivits ovan. När det gäller procentandel för övergripande mortalitet ökade antalet självmord från 1,01 \% under år 2007 till 1,27\% år 2018.

Om vi jämför dessa siffror med siffror från några grannländer som liknar Nederländerna vad gäller etnicitet, ålder, religion och kultur, så kan vi konstatera att Nederländerna har den största ökningen av antalet självmord. Ökningen av antalet självmord från år 2008 och framåt kan inte enbart förklaras i termer av ekonomiska problem, såsom några har framhållit (Francis, 2017), eftersom grannländerna påverkades på ett likartat sätt under krisen år 2007 utan att se en ökning av antalet självmord. Av dessa länder visar Belgien (som erbjuder eutanasi) de facto en minskning av antalet självmordsfall, men fortsätter att vara ett av de länder i Europa som toppar självmordsstatistiken (Boer, 2017b).

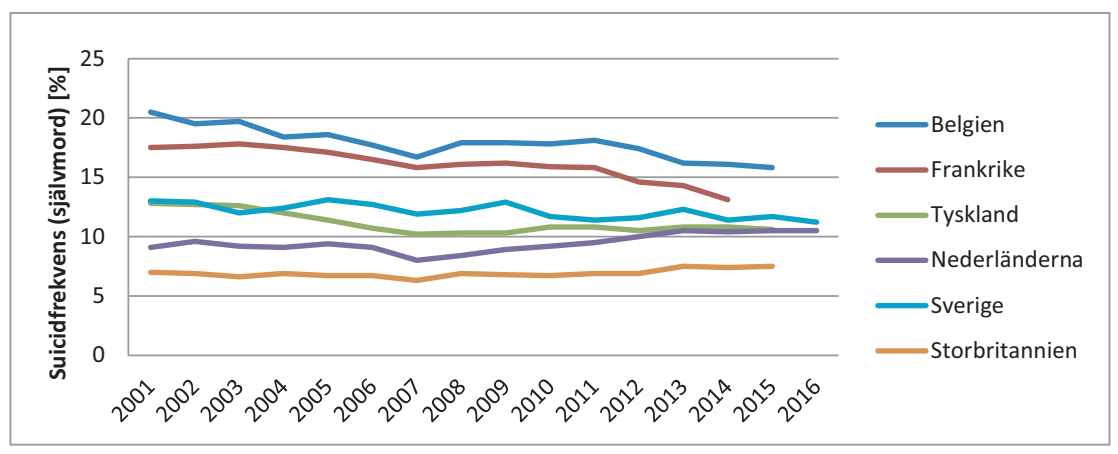

Diagram 3. Suicid (självmord) i Nederländerna jämfört med suicidfrekvens för några av grannländerna, per 100000 invånare (OECD, 2018). 


\section{6 Övrig utveckling}

Fall som accepterades av RKK-instanserna och vilka fortsätter att väcka allmän debatt (både för och emot) gäller dödshjälp vid demens, vid ackumulerade åldersrelaterade åkommor, vid psykisk sjukdom och i särskilda fall såsom blindhet, autism, sorg eller arbetslöshet i kombination med ett medicinskt tillstånd. Slutligen har även ett starkt tilltagande antal fall av »eutanasi för två» rapporterats.

Medan vi skriver utforskas och diskuteras även andra grunder. En av dem är eutanasi för personer som inte har medicinska åkommor men som har ett »fullbordat liv». Det gäller personer som är över 70 eller 75 år och som känner att de är bortkopplade, fjärmade, ensamma eller helt enkelt »fått nog» (Ministerie van Volksgezondheid, 2016). Dessutom förs diskussion om eutanasi för personer med avancerad demens som har förhandsdirektiv (livstestamente) samt eutanasi för barn i åldrarna 1-11 år. Den 11 september 2019 beslutade domstolen i Haag att frikänna en läkare i den så kallade »kaffe-eutanasin». Läkaren utförde dödshjälp på en patient i ett avancerat stadium av demens. Att denne gjorde motstånd och dödshjälpen behövde utföras med fysiskt tvång, var för domaren inte anledning att bedöma händelsen som mord. Patienten saknade beslutskompetens och hennes förhandsdirektiv, som innebar en ansökan om dödshjälp i en situation av avancerad demens, ansågs som ledande (Karasz, 2019). Denna banbrytande dom bekräftades den 23 april 2020 av Högsta domstolen. Av jämförbar vikt är en rapport som publicerades i oktober $2019 \mathrm{i}$ vilken ledande nederländska barnläkare argumenterar för att möjliggöra dödshjälp för barn mellan 1 och 12 år (Brouwer et al., 2019). De två senare utvecklingarna bryter mot befintlig nederländsk konsensus gällande att »eutanasi endast görs på begäran» och markerar en återgång till eutanasi som »barmhärtig död». Detta är den form i vilken eutanasi gjorde sitt intåg i den nederländska diskussionen år 1968 (van den Berg, 1968).

\section{Kontrollkommittéernas roll}

I den tilltagande liberala tolkningen av lagstiftningen har kontrollkommittéerna (RKK) spelat en avgörande roll. I efterhand visade sig juridiska 
kriterier, under 1990-talet ofta kallade »strikta», vara strikta främst på grund av att kommittéerna under de första åren använde vissa inofficiella »bakgrundskriterier» till vilka vi hänvisade ovan. Nederländsk lagstiftning är, till punkt och pricka, en av de liberalaste i sitt slag, inte minst på grund av kommittéernas omfattande mandat gällande tillämpningen av lagstiftningen. Sedan eutanasilagen år 2002 avger en RKK ett slutgiltigt utlåtande vid utfärdande av fastställelsedomar. Om en kommitté beslutar att ett fall uppfyller kriterierna, är ärendet stängt och åklagaren får ingen tillgång till akten. Under åren efter 2008 uppkom en mängd banbrytande rapporter: patienter med en psykiatrisk diagnos, patienter med ackumulerade åldersrelaterade åkommor, annars friska personer som led av blindhet, personer med autism, personer med demens i ett tidigt skede, personer med avancerad demens och, efter 2012, personer som hade fått hjälp utanför en befintlig patient-läkarrelation. RKK-instanserna slog fast att sådana saker förtjänar extra uppmärksamhet på grund av deras komplexitet. Men mot bakgrund av eutanasilagstifningen fann de att sådana fall inte kategoriskt kunde avslås.

Det råder inget tvivel om att en del eutanasiförespråkare välkomnade denna utveckling. RKK-ledningen framhöll med tilltagande kraft att det rörde sig om en "utforskning av eutanasilagstiftningens fulla potential». Enligt kommittéerna hade lagstiftaren alltså förutsett denna utveckling från början. Jag instämmer inte: jag tror i själva verket att många $\mathrm{i}$ parlamentet - om än inte majoriteten - inte förutsåg en mer liberal praxis som vi sett under den senaste tiden, än mindre gynnade den. En del av liberaliseringen av RKK-beslut kan kopplas till ett ganska så »jordnära» fenomen: tidsbrist. Från 2008 till 2012 såg kommittéerna inte bara en betydande ökning gällande antalet rapporter utan även en omfattande ökning gällande antalet mycket komplexa ärenden, dvs. ärenden av sådan komplex beskaffenhet att en kommitté tidigare skulle ha behövt lägga ner timmar eller dagar på varje ärende för att kunna fatta beslut. När kommittéerna väl hade fått nödvändig personalförstärkning, hade de flesta banbrytande fallen redan passerat förbi.

Tidsbrist är ett av problemen i granskningsproceduren. Ett annat problem är brist på insyn och transparens. RKK-beslut fattas bakom stängda dörrar. Inga mötesanteckningar av kommittéernas samtal och 
överläggningar görs, förutom för de delar i vilka läkare blir hörda. Oftast beskriver en dom och ett utlåtande endast en del av kommittémedlemmarnas reservationer, om ens överhuvudtaget. Domarna utfärdas utan de samhällsdebatter som borde föras i samband med sådana banbrytande beslut. I april 2017 bekräftade RKK-ordförande Jacob Kohnstamm detta problem och förespråkade möjligheten att presentera RKK:s beslut för Högsta domstolen (Regionale toetsingscommissies euthanasie, 2019; se rapport för 2016).

Ett tredje problematiskt element i granskningsproceduren är det faktum att läkare måste rapportera sina egna handlingar och därmed potentiellt bidra till sina egna åtal. Denna paradoxala situation kan hindra läkaren från att yppa alla relevanta fakta och uppgifter. Det förekommer att ärenden inlämnas i vilka svaren i det standardmässiga rapportformuläret är oproblematiska, men i vilka de bifogade medicinska handlingarna innehåller uppgifter (exempelvis om påtryckningar från familjen eller beslutskompetens) som kan vara orsak för en RKK att närmare granska ärendet. En läkare kunde i princip kringgå detta genom att inte bifoga alla handlingar, utan bara de som krävs av kommittéerna: det standardmässiga rapportformuläret, patientens skriftliga direktiv, samt rapporten från den konsulterande läkaren - SCEN-läkaren. ${ }^{9}$ Bortsett från dessa dokument, eventuellt kompletterade med samtal med de involverade läkarna, har kommittéerna inga möjligheter att kontrollera en rapports sanningsenlighet.

\section{Diskussioner}

En mer omfattande analys skulle vara på sin plats för att identifiera den kulturella bakgrunden till dessa utvecklingar än vad som kan vidtas här. Det råder inget tvivel om att det finns sanning i de observationer som professor van der Wal 2003 gjorde gällande, att det finns ett ökat behov av ett »kontrollerat livsavslut». Den statliga utvärderingen från 2017 kan även vara korrekt gällande antydan om att det föreligger en minskad

9 SCEN står för Support and Consultation Euthanasia in the Netherlands. SCEN består av ett nätverk av läkare som är utbildade för att bedöma eutanasiförfrågningar och för att hjälpa läkare att fatta beslut. 
tolerans i samhället avseende lidande (Onwuteaka-Philipsen et al., 2017). Detta innebär inte en minskad grad av medkänsla utan snarare att medkänsla alltmer även omfattar beredskap för dödshjälp.

Det som är avgörande i alla diskussioner om dödshjälp är hållbarheten hos valda kriterier. Under åren har kriterierna som valts av nederländarna visat sig vara både svårhanterliga och moraliskt diskutabla. Detta gäller särskilt kriteriet outhärdligt lidande. Under åren, med en palliativ vård som gjort betydande framsteg, har kommitéerna sett beskrivningarna »outhärdligt lidande» svänga från fysiska orsaker såsom smärta, illamående, trötthet och dyspné (andnöd) till mer andliga orsaker: bristande kontroll, vårdberoende, meningslös väntan och ensamhet. Om fysiskt lidande upplevs som outhärdligt eller inte beror i hög grad på individuella faktorer (religiösa, sociala, biografiska, ibland till och med ekonomiska). Med hänsyn till dessa skiljaktigheter mellan patienter måste läkare till syvende och sist förlita sig på patientens egna bedömning av sitt lidande. I praktiken har kriterierna »outhärdligt lidande» och »informerad begäran» således blivit svåra att särskilja.

Bortsett från dessa epistemiska svårigheter (dvs. svårigheter gällande att få insikt), så finns det även en etisk angelägenhet: vem - läkare, konsulterande läkare, RKK-medlemmar - kan hävda att en person som säger att lidandet är outhärdligt inte lider »i en grad som är tillräckligt allvarlig»? Kriteriet outhärdligt lidande har oavsiktligt bidragit till en arena för förhandlingar mellan patienter och läkare, öppen för både medicinsk förmyndarmentalitet och patientmanipulation. Medicinsk förmyndarmentalitet, på grund av att ett läkarutlåtande gällande patientens situation kan påverkas av läkarens yrkesmässiga, känslomässiga, etiska och religiösa betänksamheter inför eutanasi. Och patientmanipulation, på grund av att patienter som har högre utbildning och bättre kan presentera sitt fall för en läkare har större chans att få sin anmodan beviljad. En sådan form av manipulation illustreras i en artikel i KNMG:s veckotidning Medisch Contact som har titeln »Eutanasi för nybörjare. Tio tips för en framgångsrik begäran om dödshjälp» (van Tol, van de Vathorst \& Keizer, 2008). Enligt författarna kan patienter som understryker de fysiska aspekterna gällande deras lidande, som avstår från att hänvisa till att vara en belastning för sina anhöriga, som avstår från att hänvisa till 
sina hobbies glädjeämnen och framtidsplaner, som stannar kvar i sängen när en (konsulterande) läkare kommer på besök istället för att öppna dörren själva etc., ha en större chans att erhålla dödshjälp. Att övertyga en läkare att utföra eutanasi kan sålunda bli ett spel, en förhandlingsprocess med ett resultat som kan vara olika från patient till patient och från läkare till läkare. Bara en del kommer att lyckas få igenom sin begäran. Effekten kan vara en oavsiktlig men allvarlig ojämlikhet mellan patienter, något som är svårt att vidmakthålla i en era av rättvisa och patientens självbestämmanderätt.

Även två andra kriterier - frånvaron av en förbättringsutsikt och frånvaron av ett rimligt alternativ - är föremål för patientens individuella preferens. Det förekommer att en patient har en dödsönskan innan en obotlig sjukdom inträffar och avböjer en livsräddande eller livsförlängande behandling. Det kan också förekomma att en patient avfärdar palliativ vård som tillval som kunde erbjuda lindring: antidepressiva läkemedel, smärtlindrande läkemedel, lugnande medel, tillträde till ett vårdhem eller hospice. De flesta läkare tar inte sådana avböjanden för givna och kommer att försöka övertyga patienten. RKK-praxis fordrar att en läkare måste ha utforskat alternativa vårdmöjligheter tillsammans med patienten. Men när allt kommer omkring, så måste patientens rätt att vägra en behandling respekteras.

$\mathrm{Nu}$ när dödshjälp håller på att bli ett av de föredragna sätten att dö: var detta de nederländska lagstiftarnas ursprungliga avsikt? En del stiftare av lagarna från 1994 och 2002 har förvisso förutsett den utveckling som vi diskuterat här och välkomnat den. Jag är dock övertygad om att eutanasilagen för de flesta i det nederländska samhället, inklusive politiker, läkare och andra medborgare, ursprungligen hade en mer begränsad ambition: att tillhandahålla human dödshjälp till döende patienter. Kontexten för acceptans av dödshjälp i Nederländerna under 1980- och 1990-talen var terminala fysiska sjukdomstillstånd, i vilka eutanasi var en sista tillflykt för att förhindra en plågsam död. Under det senaste decenniet har vi kunnat bevittna förekomsten av en andra typ av eutanasi: eutanasi som ett sätt att avsluta ett plågsamt liv. Att detta hände i ett land som har det mest omfattande kontrollsystemet av eutanasi i världen, som har sjukförsäkring för alla, högt utvecklad 
palliativ vård, en central roll för familjeläkare och ett av världens bästa pensionssystem väcker frågan huruvida andra länder någonsin kommer att ha möjlighet att förhindra en liknande utveckling. En del länder som diskuterar dödshjälp har vidtagit åtgärder för att förhindra en oavsiktlig utvidgning (Willingham, 2017). Kanada är ett exempel: endast patienter vars naturliga död är rimligt förutsägbar kan ansöka om dödshjälp. Under det senaste året har detta kriterium utmanats i ett flertal domstolsfall: att exkludera patienter med kroniska sjukdomar från dödshjälpsprocedurer anses diskriminerande. År 2019 beslöt Quebecs Superior Court i ett av dessa fall att en inskränkning av dödshjälp till terminala patienter strider mot grundlagen (Rukavina, 2019). Erfarenheten har således visat att de begränsningar som varje eutanasilag nödvändigtvis innehåller anses av många som en ny orättvisa som borde tas bort.

Den nederländska erfarenheten är ett must read för andra länder som överväger legalisering av dödshjälp. Utifrån min observation har nederländsk tvåstegslegalisering (1994 och 2002) i stället för att tillfredsställa behov snarare gett upphov till nya. Det råder ingen tvekan; valmöjligheten dödshjälp är en trygghet för många och uttrycker respekt för patienternas självbestämmanderätt. Vi kan knappast överskatta det allvar som mycket lidande innebär, i synnerhet för de personer vars lidande är kroniskt och för dem som inte har en snar naturlig död att se fram emot. Vi skall heller inte ifrågasätta uppriktigheten hos dem som lämnar in en begäran om dödshjälp eller ifrågasätta integriteten och medkänslan hos läkare som utför dödshjälp. Jag har sett exempel på hjärtskärande lidande, både hos patienter med terminala fysiska sjukdomstillstånd och hos dem som har en något längre förväntad livslängd. Men min observation är också att friheten hos vissa att kunna få sina liv avslutade påverkar andra som befinner sig psykiskt, emotionellt, socialt eller på annat sätt i riskzonen.

Utifrån mitt perspektiv har beslutskompetenta vuxna personer en moralisk rättighet till icke-inblandning när de vill avsluta sina egna liv. I många samhällen (inklusive Nederländerna) inkluderar detta även en juridisk rättighet till icke-inblandning. Men utöver en sådan rättighet är frågan huruvida vi skall förespråka en statlig inblandning när det gäller 
att underlätta och reglera en sådan praxis. Jag har blivit mer skeptisk gentemot möjligheten till en sådan inblandning. Dödshjälp tillhandahåller inte enbart tröst utan har även till viss grad bidragit till en kultur av förtvivlan, i vilken vår beslutsamhet att uthärda livets oundvikliga svårigheter hotas av den vädjande tillgängligheten av den mest drastiska av alla »lösningar»: att överge livet helt och hållet. En del patienter tycks vara tillräckligt starka för att kunna fatta sina beslut med total frihet. Men det nederländska exemplet ger orsak att dra slutsatsen att utbud, precis som med andra mänskliga handlingar och behov, kan ha skapat efterfrågan. De länder som överväger att tillåta dödshjälp för sina medborgare - med start från en kontext av terminala fysiska sjukdomstillstånd - skulle kunna dra fördel av att titta närmare på aktuell praxis och diskussioner i Nederländerna och föreställa sig att detta är en situation i vilken de kan komma att befinna sig om tjugo år från nu.

\section{Referenser}

Boer, T. A. (2016). Vrij om te sterven. Nederland, religie en het zelfgekozen levenseinde.

Groen van Prinstererlezing. Amersfoort: Wetenschappelijk Instituut voor de ChristenUnie.

Boer, T. A. (2017a). De derde evaluatie van de Wet Toetsing Levensheide en Hulp bij Zelfdoding: over de relatie van empirie, normativiteit en politiek. Tijdschrift voor Gezondheidszorg en Ethiek, 27(4), 98-104.

Boer, T. A. (2017b). Does euthanasia have a dampening effect on suicide rates? Recent experiences from the Netherlands. Journal of Ethics in Mental Health, 10(1), 1-9.

Boer, T. A. (2018). Dialectics of lead: Fifty years of Dutch euthanasia and its lessons. International Journal of Environmental Studies, 75(2), 239-250.

Boer, T. A. \& Groenewoud, A. S. (2020). Euthanasia by family doctors in the Netherlands: Comparing low incidence and high incidence regions. Forthcoming.

Brouwer, M., van der Heide, A., Hein, I., Maeckelberghe, E., Verhagen E. \& van de Wetering, V. (2019). Medische beslissingen rond het levenseinde bij kinderen 1-12. Onderzoeksrapportage. Groningen/Rotterdam. Hämtad från https://www

rijksoverheid.nl/binaries/rijksoverheid/documenten/rapporten/2019/09/281 medische-beslissingen-rond-het-levenseinde-bij-kinderen-1-12/medischebeslissingen-rond-het-levenseinde-bij-kinderen-1-12.pdf

Centraal Bureau voor de Statistiek. (2019). www.cbs.nl. 
DeJong, A. (2019, 11 april). Voor het eerst in jaren daalt het aantal euthanasiemeldingen in Noord- en Zuid-Holland. Leidsch Dagblad. Hämtad från https://www.leidschdagblad.nl/cnt/dmf20190411_5982489/voor-het-eerst-injaren-daalt-het-aantal-euthanasiemeldingen-in-noord-en-zuid-holland

Distelmans, W. (2017). Euthanasie: trage euthanasie of sociale dood? Antwerpen: Houtekiet.

Expertisecentrum euthanasie. (2020). 2019: 22 procent meer hulpvragen. Den Haag: Expertisecentrum euthanasie. Hämtad från https://expertisecentrumeuthanasie n1/2019-22-procent-meer-hulpvragen/

Francis, N. (2017, 12 mai). Margaret Somerville's claims on assisted suicide don't line up with the data. $A B C$ Religion and Ethics. Hämtad från http://www.abc.net.au/ religion/articles/2017/05/12/4668055.htm?site=goldfields.

Gevers, S. (1996) Euthanasia: Law and practice in The Netherlands. British Medical Bulletin, 22(2), 326-333.

Karasz, P. (2019, 11 september). Dutch court clears doctor in euthanasia of dementia patient. The New York Times. Hämtad från https://www.nytimes.com/2019/09/11/ world/europe/netherlands-euthanasia-doctor.html

Lynch, T., Connor, S. \& Clark, D. (2013). Mapping levels of palliative care development: A global update. Journal of Pain and Symptom Management, 45 (6), 1094-1107.

Ministerie van Volksgezondheid. (2016). Kamerbrief met kabinetsreactie en visie op burgerinitiatief Voltooid Leven. Den Haag. Hämtad från https://www.riiksoverheid. nildocumenten/kamerstukken/2016/10/12/kabinetsreactie-en-visie-voltooid-leven

OECD. (2018). OECD Data Health Status Suicide Rates. Hämtad från https://data. oecd.org/healthstat/suicide-rates.htm

Onwuteaka-Philipsen, B. D., Gevers, J. K. M., van der Heide, A. \& van Delden, J. J. M. (2007). Evaluatie Wet toetsing levensbeëindiging op verzoek en hulp bij zelfdoding. Den Haag: ZonMw.

Onwuteaka-Philpsen, B. D., Legemaate, J., van der Heide, A. \& van Delden, J. J. M. (2017). Derde evaluatie Wet toetsing levensbeëindiging op verzoek en hulp bij zelfdoding. Den Haag: ZonMw.

Oostveen, M. (2003, 24 mai). Het grote experiment. NRC Handelsblad.

Rukavina, S. (2019, 11 september). Quebec judge overturns parts of federal, provincial laws on medically assisted dying. CBC News. Hämtad från https:// www.cbc.ca/news/canada/montreal/medically-assisted-dying-law-overturnedquebec-1.5279067

Regionale toetsingscommissies euthanasie. (2019). Jaarverslagen (2002-2018). Hämtad från https://www.euthanasiecommissie.nl/de-toetsingscommissies/jaarverslagen Samen op Weg Kerken. (1998). Euthanasie en pastoraat. Den Haag: Boekencentrum. Staatscommissie Euthanasie. (1985). Rapport van de Staatscommissie Euthanasie. Den Haag: Staatsuitgeverij. 
Stichting Farmaceutische Kengetallen. (2017). Palliatieve sedatie vaker ingezet bij sterfgevallen. Hämtad från https://www.sfk.nl/publicaties/PW/2017/palliatievesedatie-vaker-ingezet-bij-levenseind

Thomas, J. (1984, 28 november). Dutch court acts on 'right to die. The New York Times.

van den Berg, J. H. (1968). Medische macht en medische ethiek. Nijkerk: Callenbach. van der Heide, A., Legemaate, J., Onwuteaka-Philipsen, B. D., Bolt, E. \& van Delden, J. J. M. (2012). Tweede Evaluatie Wet Toetsing Levensbeëindiging op verzoek en hulp bij zelfdoding. Den Haag: ZonMw.

van der Maas, P. J., van Delden, J. J. M., van der Wal, G. \& Pijnenborg, L. (1991).

Medische beslissingen rond het levenseinde: het onderzoek voor de Commissie

Onderzoek Medische Praktijk inzake Euthanasie. Den Haag: Sdu Uitgeverij.

van der Wal, G., van der Heide, A., Onwuteaka-Philipsen, B. D. \& van der Maas,

P. J. (2003). Medische besluitvorming aan het einde van het leven. De praktijk en de toetsingsprocedure euthanasie. Utrecht: De Tijdstroom.

van der Wal, G. \& van der Maas, P. J. (1996). Euthanasie en andere medische

beslissingen rond het levenseinde. Den Haag: Sdu Uitgeverij.

van Tol, D., van de Vathorst, S. \& Keizer, B. (2008). Euthanasie voor beginners.

Tien suggesties voor een succesvolle stervenswens. Medisch Contact, 63(4).

Weyers, H. A. M. (2002). Euthanasie: het proces van rechtsverandering. Groningen:

Rijksuniversiteit Groningen.

Willingham, R. (2017, 21 juli). Euthanasia deaths to be permitted in Victoria by 2019 under committee proposal. ABC (Australia). Hämtad från http://www.abc.net.au news/2017-07-21/victoria-assisted-dying-available-2019-report-says/8730346

\section{Ordforklaringer}

allmän åklagare: statsadvokaten $(\mathrm{D}, \mathrm{N})$

angelägenhet: problem $(\mathrm{D}, \mathrm{N})$

anledning: anledning/årsag (D), grunn (N)

avböjer: afviser/avviser (D/N)

avsevärt: betragteligt/betraktelig $(\mathrm{D} / \mathrm{N})$

befarade: frygtede/fryktede $(\mathrm{D} / \mathrm{N})$

befintlig: eksisterende $(\mathrm{D}, \mathrm{N})$

de bifogade medicinska handlingarna: de vedlagte medisinske dokumenter $(D, N)$

grannländer: nabolande/naboland $(\mathrm{D} / \mathrm{N})$

gynnade: billigede/gik ind for (D), gikk inn for (N)

i syfte att: med den hensigt at (D), med formål å (N)

i åtanke: in mente $(\mathrm{D}, \mathrm{N})$ 
illamående: kvalme (D, N)

ilska: vrede (D), sinne (N)

fjärmade: fremmedgjorte $(D, N)$

förespråkare: fortalere $(\mathrm{D})$, forkjempere $(\mathrm{N})$

förtroende: tillid/tillit $(\mathrm{D} / \mathrm{N})$

medvetande: bevidsthed/bevissthet $(\mathrm{D} / \mathrm{N})$

medvetenheten: bevidstheden/bevisstheten $(\mathrm{D} / \mathrm{N})$

omtanke: omsorg $(\mathrm{D}, \mathrm{N})$

outhärdligt: uudholdelig/uutholdelig $(\mathrm{D} / \mathrm{N})$

sanningsenlighet: sandfærdighet/sannferdighet $(\mathrm{D} / \mathrm{N})$

sjukvård: sundhedsvæsen $(\mathrm{D})$, helsetjeneste $(\mathrm{N})$

skyldighet: pligt/plikt (D/N)

slutgiltiga: endelige $(\mathrm{D}, \mathrm{N})$

slutsatsen: konklusionen/konklusjonen (D/N)

tillhandahållen: ydede (D), ga $(\mathrm{N})$

tillämpligt: aktuelt/relevant $(\mathrm{D} / \mathrm{N})$

tillämpningen: anvendelsen $(\mathrm{D}, \mathrm{N})$

uppskattningar: estimater $(\mathrm{D}, \mathrm{N})$

utbud: udbud (D), tilbud (N)

utlåtande: erklæring $(\mathrm{D}, \mathrm{N})$

utmanad: udfordret/utfordret $(\mathrm{D} / \mathrm{N})$

utvärdering: evaluering $(\mathrm{D}, \mathrm{N})$

varaktig: langvarig $(D, N)$

vare sig: hverken/verken $(\mathrm{D} / \mathrm{N})$

vidtas: foretages/foretas $(\mathrm{D} / \mathrm{N})$

vädjan: appel/appell $(\mathrm{D} / \mathrm{N})$

vånda: lidelse $(\mathrm{D}, \mathrm{N})$

yppa: afsløre/avsløre (D/N)

yrka på: hævde/hevde $(\mathrm{D} / \mathrm{N})$

överge: opgive/oppgi (D/N)

övergripande: tilgrundliggende/tilgrunnliggende $(\mathrm{D} / \mathrm{N})$

överskatta: overvurdere $(\mathrm{D}, \mathrm{N})$

ägde rum: fandt sted/fant sted $(\mathrm{D} / \mathrm{N})$

ärendet: sagen/saken $(\mathrm{D} / \mathrm{N})$

åkommor: lidelser $(\mathrm{D}, \mathrm{N})$

åtagande: forpligtelse/forpliktelse $(\mathrm{D} / \mathrm{N})$

återhämtningsutsikt: helbredelsesmulighed (D), mulighet for bedring (N)

åtgärder: foranstaltninger (D), tiltak $(\mathrm{N})$ 



\title{
En kritisk granskning av Oregonmodellen
}

\author{
Anne-Berit Ekström
}

Avdelningen för pediatrik, Institutionen för kliniska vetenskaper, Göteborgs Universitet

\section{Mikaela Luthman}

Överläkare i palliativ vård

\begin{abstract}
The so-called Oregon model has been described as a more attractive and safer alternative for assisted dying than the controversial euthanasia laws in the Benelux countries. Many advocates of assisted dying believe that the Oregon model, which implies physician-assisted suicide, is better adapted to Swedish (Nordic) conditions. In order to be able to offer assisted dying according to the Oregon model, seven criteria must be met. In this chapter, we will analyse the criteria and examine whether the practices of the Oregon model meet them. Is it a safe model to help severely ill people from suffering during their very last stage of life? To what extent can the model guarantee security and justice for those involved? Finally, we want to investigate whether it can be a suitable model for the Nordic countries.
\end{abstract}

Keywords: assisted dying, justice, Oregon model, physician-assisted suicide, safety

\section{Inledning och bakgrund'}

I Beneluxmodellen för dödshjälp, som tillämpas i Belgien, Luxemburg och Nederländerna, är både eutanasi och assisterat döende tillåtet. Initialt gavs endast dödshjälp till patienter i livets slutskede, men efterhand har det skett en glidning i praxis till att även erbjudas patienter med längre

1 Kapitlet bygger på vår rapport från Claphaminstitutet (Luthman \& Ekström, 2017).

Sitering av denne artikkelen: Ekström, A.-B. \& Luthman, M. (2020). En kritisk granskning av Oregonmodellen. I M. A. Horn, D. J. H. Kleiven \& M. Magelssen (Red.), Dødshjelp i Norden? Etikk, klinikk og politikk (Kap. 14, s. 275-290). Oslo: Cappelen Damm Akademisk. https://doi.org/10.23865/noasp.96.ch14. Lisens: CC BY 4.o. 
förväntad överlevnad (se kap. 13). Konsekvenserna av dödshjälpslagarna i Nederländerna och Belgien oroar många (Statens medicinsk-etiska råd, 2017; kap. 13). Det har medfört att dödshjälpsförespråkare i Sverige inte längre lyfter fram dessa länder som positiva exempel. Idag framförs istället kraven på att införa dödshjälp enligt den modell som 1997 infördes i den amerikanska delstaten Oregon, vilket givit upphov till dess namn The Oregon Death With Dignity Act (DWDA). Sedan dess har modellen även införts i ett antal övriga amerikanska delstater. Modellen bygger på läkarassisterat självmord (PAS) och är den mest kända modellen för detta i världen.

\subsection{Oregonmodellens sju kriterier}

Oregons hälsovårdsmyndighet har ställt upp sju kriterier för genomförandet av läkarassisterat självmord under DWDA (se tabell 1).

Tabell 1. Oregonmodellens sju kriterier.

\begin{tabular}{|c|l|}
\hline 1. & Muntlig begäran \\
\hline 2. & Skriftlig begäran \\
\hline 3. & Bekräftad diagnos och prognos \\
\hline 4. & Bedömning av beslutsförmåga \\
\hline 5. & Psykiatrisk undersökning vid misstanke om bristande beslutsförmåga \\
\hline 6. & Information om alternativ till dödshjälp \\
\hline 7. & Patienten ska rådas att berätta för en nära släkting \\
\hline
\end{tabular}

Patienten måste muntligen begära dödshjälp av sin läkare vid två tillfällen. Mellan dessa tillfällen ska det minst gå 15 dagar och det finns ingen övre tidsbegränsning. I juli 2019 signerade Oregons guvernör Kate Brown ett tillägg till lagen som ger patienter med en prognos om förväntad överlevnad mindre än 15 dagar, rätt att inte vänta något angivet antal dagar för att göra den andra begäran (Senate Bill 579, 2019).

Patienten ska förse sin läkare med en skriftlig begäran, undertecknad i närvaro av två vittnen. Av dessa ska åtminstone ett vittne inte vara en släkting till patienten och inte heller en person som på något sätt vid tidpunkten för undertecknandet av förfrågan har rätt att ärva patienten. 
Både patientens läkare och en konsulterad läkare ska bekräfta patientens diagnos och prognos (det vill säga att patienten förväntas ha högst sex månaders återstående livstid). Patientens läkare och en konsulterad läkare måste bedöma att patienten är kapabel att fatta och kommunicera egna beslut om sin sjukvård. Om någon av läkarna bedömer att patientens omdöme är påverkat av en psykisk sjukdom (som exempelvis depression) ska patienten hänvisas till psykiatrisk undersökning. Patientens läkare ska informera patienten om möjliga alternativ till dödshjälp, såsom hospicevård och smärtlindring.

Patienten kan återkalla sin begäran när som helst och på vilket sätt som helst och läkaren ska erbjuda patienten möjlighet till det då den angivna 15-dagarsperioden är avslutad. Läkaren ska rapportera all förskrivning av dödsbringande preparat till Oregons hälsovårdsmyndighet Oregon Public Health Division (OPHD). Apotekarna ska också informeras om det förskrivna medlets slutliga användning. Dessa har en skyldighet att informera patienten om hur medlet ska intas, om eventuella biverkningar och råd om medel mot illamående, hur personen ska agera om han eller hon ändrar sig efter att ha intagit medlet samt slutligen hur drog som ej kommer till användning ska omhändertas. När väl medlet är utskrivet är det patienten själv som förvaltar det. I lagen anges under rubriken Attending physician responsibilities också att läkaren ska, för att säkerställa att patienten fattar ett informerat beslut, upplysa denne om bland annat de potentiella risker som är förknippade med att inta medicinen samt det troliga resultatet av att inta den.

Det sista kriteriet innebär att patientens läkare ska rekommendera, men inte kräva, att patienten upplyser sin närmaste släkting om sin begäran om dödshjälp. Detta är i linje med allmän hälsolag: släktingar har ingen oberoende rätt till information när patienten är beslutskompetent.

\subsection{Statistik från 20 år med Oregonmodellen}

Under de 20 år modellen tillämpats har andelen dödsfall ökat från ca 25/ år under perioden 1998-2002 till 168 under 2018, vilket motsvarar 0,46\% av samtliga dödsfall. 
I rapporten för 2018 var $52 \%$ av patienterna män och $48 \%$ kvinnor. Åldern varierade mellan 40 och 102 år, 97 \% var av kaukasiskt ursprung, $97 \%$ hade fullföljt gymnasial eller högre utbildningsnivå. $98 \%$ var inskrivna i palliativ vård.

Olika former för cancer var den dominerande diagnosen men andelen har minskat från 79 \% under perioden 1998-2002 och 84 \% under 20032007 till 62 \% 2018. Neurologiska sjukdomar, med övervikt för amyotrofisk lateral skleros (ALS), har ökat från 9 \% under perioden 1998-2002 till $15 \%$ 2018. Under 1998-2002 genomfördes en psykiatrisk bedömning av $23 \%$ av patienterna; 2018 var andelen bara 1,2 \%. Anledningen till att dödshjälp begärdes var förlust av autonomi i $92 \%$ av fallen i 2018 (mot 82 \% under perioden 1998-2002), minskad förmåga att delta i glädjefyllda aktiviteter $91 \%$ (77 \%), förlust av värdighet $67 \%$ (-), förlust av kontroll över kroppsfunktioner $37 \%$ (57 \%), känslan av att vara en börda för familjen $54 \%$ (34\%), bristande symptomkontroll, främst smärta i $22 \%$ (26 \%).

\section{Oregonmodellen - en risk- och konsekvensanalys}

Att införa ny teknik eller nya tillämpningar av medicinska behandlingar innebär krav på säkerhet. Särskilt gäller detta verksamheter med hög risk, som exempelvis avancerad kirurgi, nya cytostatika med potentiellt allvarliga biverkningar och läkemedel till gravida. Dödshjälp måste hänföras till kategorin högriskverksamhet då konsekvenserna är irreversibla. Med säkerheten i fokus, uppfyller Oregonmodellen de krav som måste ställas?

2.1 Det första kriteriet om muntlig begäran om dödshjälp är tänkt att vara som ett samtal mellan patient och den läkare de har haft kontakt med under en längre tid och som därför är väl insatt i patientens problematik. Det har dock rapporterats fall av läkarassisterat självmord där läkare skrivit ut dödliga preparat till patienter som de har känt i mindre än en vecka (Hendin \& Kamisar, 2009).

När en person erhåller ett besked om att man har drabbats av en obotlig sjukdom utlöser detta i de allra flesta fall en krisreaktion. Den 15 dagars 
betänketid som regelverket i Oregon förskriver - är den tillräcklig när en individen fattar sitt sista och oåterkalleliga beslut? (Lundgaard, 2019).

Det är välkänt för dem som arbetar med vård av döende att positionerna kan ändras under sjukdomsförloppet. När det chockerande meddelandet om dödlig sjukdom ges förefaller det ofta omöjligt att stå ut, och om patienten i detta skede framför ett önskemål om dödshjälp kan det vara svårt för läkaren att förhålla sig till denna önskan. Hur ska man kunna lita på att sådana uttalanden står sig över tid och att inte läkaren bidrar till att patienten tar sitt liv på felaktiga premisser? Utifrån att människan är anpassningsbar bör det leda till försiktighet med alltför snabba beslut.

2.2 Kravet om att den skriftliga begäran ska vara bevittnad är en säkerhetsmekanism. Det är dock viktigt att påminnas om att det ena vittnet kan vara en arvinge till patienten vilket kan innebära att det då inte finns något skydd mot vittnenas egenintresse. Man kan då fråga sig - finns det egentligen något skydd mot att dessa vittnen i värsta fall kan äventyra patientens valfrihet och i dess förlängning även leda till tvång? (Dore, 2009). Finns det inte då en inbyggd risk för att extra utsatta och sårbara personer kan bli manipulerade till att efterfråga assisterat självmord?

2.3 Kriteriet avseende bekräftad diagnos och prognos säger att patienten ska ha en förväntad överlevnad på sex månader eller mindre. Sjukvårdspersonal med erfarenhet av palliativ vård eller från annan verksamhet där de möter döende människor - till exempel onkologer - vet hur svårt det är att bedöma beräknad överlevnad. Med nya behandlingsmetoder, kanske framförallt de moderna immunmodulerande behandlingarna, har överlevnaden för många cancerformer drastiskt ändrats och gjort prognoser för långtidsöverlevnad än svårare. Ett tydligt exempel är immunterapi vid malignt melanom, men även många andra cancerformer (Pahlén, 2018).

Data från Craig New, Research Analyst, Public Health Division, DWDA, visar också att av dem i Oregon som inte tog den förskrivna drogen levde nästan åtta procent efter sex månader vilket belyser svårigheten att prognosticera överlevnad. 
I regelverket anges att det är den läkare som har det primära ansvaret för vård och behandling av patientens terminala sjukdom som gör den första bedömningen och som sedan konsulterar en andra läkare. Det till synes strikta regelverket hindrar dock inte en patient som blivit nekad assisterat självmord av sin ordinarie läkare från att uppsöka andra läkare, tills han eller hon hittar några som bedömer att kriterierna är uppfyllda. I de fall när detta fenomen har förekommit, har läkaren ofta känt patienten under en väldigt kort tid. Mediantiden för patient-läkarrelation 2018 var 10 veckor med ett spann på 1-1108 (Oregon Public Health Division, 2019). Räcker en veckas relation till att säkerställa en säker bedömning i en så avgörande fråga som ifall patienten ska ta sitt liv? En långvarig patient-läkarrelation kan vara en mekanism som ökar läkarens möjlighet att upptäcka en underliggande depressionsdiagnos (Association of Northern California Oncologists \& Medical Oncology Association of Southern California, 2007).

Lagen föreskriver heller inte vilka läkare som ska konsulteras för en andra bedömning. En läkare med positiv inställning till läkarassisterat självmord kan välja att konsultera en annan läkare med samma inställning, vilket ytterligare äventyrar en opartisk bedömning. Data från Oregon 2018 visade också att det största antalet av de läkare som förskriver recept för PAS bara skrev ett enda, medan det fanns några som skrev betydligt fler; en enskild läkare skrev 35 recept under ett år.

2.4 Bestämmelsen om beslutsförmåga. En rad studier har visat att de dominerande symptom som ligger bakom förfrågan om PAS inte är fysiska såsom smärta eller illamående. Istället är det depression, psykologiskt lidande och rädsla för att förlora kontroll som identifieras som de avgörande livsslutsfrågorna (Association of Northern California Oncologists \& Medical Oncology Association of Southern California, 2007).

Självmordsbenägna och svårt sjuka människor kan vara ambivalenta inför döden (se kap. 11). Även läkare som är vana vid självmordsbenägna patienter (psykiatriker) kan missa denna ambivalens och vid svår, livshotande sjukdom föreligger en än större risk att läkarna tar patientens förfrågan om att dö bokstavligt (Hendin \& Foley, 2008, s. 1622). Många patienter som ber om assisterat självmord gör det på grund av fruktan för vad som kommer att hända med dem. Ofta är det »inte döden, men tiden 
fram till den» som oroar mest. Kunskap om lindring i livets slut och möjlighet att informera patienten om det är därför mycket viktig (se kap. 10).

Personer med depression kan lagligen få dödliga preparat i Oregon, eftersom de tekniskt sett är berättigade till det, så länge de bedöms vara »kompetenta i lagens mening» och förutsatt att även de övriga kriterierna är uppfyllda. Denna skrivning innebär att de inte lider av en psykisk sjukdom eller depression som påverkar deras omdöme. Men depression är ett behandlingsbart sjukdomstillstånd och även om personen i lagens mening kan anses vara kompetent att fatta ett beslut om att avsluta sitt liv, enbart för att depressionen inte anses påverka hans eller hennes lagliga kompetens, så är det inte lege artis att inte i första hand göra ett ordentligt behandlingsförsök.

Att reducera den psykiatriska rådgivningen till en fråga om kompetens ignorerar också alla andra psykologiska faktorer som spelar in i förfrågan om läkarassisterat självmord (Golden \& Zoanni, 2010). Bestämmelsen om beslutsförmåga ger ett intryck av patientens egenkontroll. Men det är läkaren som tar beslut om att patienten kan få dö genom att bevilja patientens önskan om läkarassisterat självmord. Önskan är patientens men om läkaren inte bara diskuterar den teoretiska möjligheten att man i personens mycket svåra situation överväger att avsluta livet i förtid, utan faktiskt rent konkret hjälper till - hur påverkar det en ambivalent person i en oerhört utsatt situation? Beslutsförmågan är ännu svårare att värdera objektivt än förväntad överlevnadstid. Bedömningen varierar från läkare till läkare och kommer oundvikligen att påverkas av läkarens personliga värderingar. Läkare kan riskera att, också omedvetet, styra patienten mot det beslut som läkaren själv tycker är det lämpligaste i den aktuella situationen. På samma sätt kan den patient som önskar dödshjälp söka den eller de läkare som är benägna att bedöma patienten som beslutskapabel.

2.5 Avseende psykiatrisk undersökning vid misstanke om bristande beslutsförmåga: Ambivalens är inte sällan förekommande hos patienter med cancer i terminalt stadium (Johansen, Hølen, Kaasa, Loge \& Materstvedt, 2005). Detta medför att det föreligger en komplicerad situation då läkaren å ena sidan ska ta ställning till om patienten ska tillåtas ta sitt liv enligt Oregonmodellen eller å andra sidan övertalas att inte ta sitt 
liv eftersom patienten troligen är ambivalent på åtminstone något plan. Det kan även för en erfaren läkare vara vanskligt att avgöra om patienten i grunden önskar medmänsklig omsorg eller har en behandlingsbar depression (Ottosson, 2009). Under 2018 skrev 103 läkare i Oregon ut 249 recept varav endast 3 patienter, det vill säga 1,2 \%, remitterades för psykiatrisk bedömning (Oregon Public Health Division, 2019).

2.6 Information om alternativ till dödshjälp såsom hospicevård och smärtlindring ska ges. Däremot måste läkaren som ska informera inte själv vara kunnig i palliativ vård. Utan sådan kunskap kan dock läkaren ha bristande kompetens att presentera alternativa möjligheter på ett tillfredsställande sätt och därmed inte heller göra dem verkligt tillgängliga (Hendin \& Foley, 2008, s. 1615).

2.7 Om patientens anhöriga inte informeras innan det assisterade självmordet kan detta hindra familjen från att till exempel uttrycka sin tillgivenhet på sådana sätt att de skulle kunna ändra patientens beslut. Om de nära anhöriga inte informeras kan det medföra en förödande sorg och skuld i likhet med det som kan ses hos dem som lämnas kvar efter ett självmord.

Det är dock svårt för en läkare att vara säker på att det inte förekommer tvång i de fall familjen vet om att patienten har efterfrågat läkarassisterat självmord, när läkaren inte har mött familjen och sett samspelet mellan dem och patienten (Hendin \& Foley, 2008, s. 1626).

\section{Syftet med Oregonmodellen - kontroll och autonomi}

Den största amerikanska organisationen som arbetar för dödshjälp är »Compassion and Choices». Dess vision är ett samhälle där människor åtnjuter ett fullt spektrum av valmöjligheter för att kunna dö bekvämt, värdigt och med kontroll. Det som sannolikt ökar efterfrågan på läkarassisterat självmord är att det för individen handlar om bibehållen autonomi och kontroll. Oregon har legat längst fram i denna trend. Det ursprungliga motivet till att lagen gick igenom var att hjälpa terminalt 
sjuka patienter att påskynda döden. Sedan lagen trädde i kraft har diskussionen om läkarassisterat självmord utvecklats till att alltmer handla om möjlighet för den enskilde att få utöva kontroll över sin död. I OPHD:s årliga rapport för 2018 framkom att de största bekymren för dem som begått läkarassisterat självmord var: förlust av autonomi, minskad förmåga att delta i aktiviteter som gör livet njutbart samt förlust av värdighet. Men känslan av att vara en börda för omgivningen beaktas också, vilket för vissa kan vara grunden för ett frivilligt beslut men det kan också finnas en risk att begäran grundad på denna orsak inte är frivillig (Warnock, 2008; se också kap. 5).

Det föreligger svårigheter att enbart begränsa dödshjälp till terminalt sjuka eftersom patienten kan neka behandling och därmed förvandla en botbar eller kronisk sjukdom till en terminal sådan. Om en patient som lider av depression och är självmordsbenägen drabbas av en livshotande sjukdom, till exempel vissa cancerformer som med behandling skulle kunna botas, eller diabetes som kan hållas i schack med insulin, tackar nej till livsuppehållande behandling och därmed blir terminalt sjuk kan den patienten via Oregonmodellen få en legaliserad död som i verkligheten är ett självmord.

\subsection{En säker död?}

Oregons lag om assisterat självmord täcker endast in tiden fram till och med utskrivandet av receptet för det dödliga preparatet. Det finns inga skyddsmekanismer för att säkerställa att patienten medvetet och/eller frivilligt tar dosen. Det är statens ansvar att »säkerställa att alla kriterier fram till utskrivandet av läkemedlet är uppfyllda». Att lagen inte täcker vad som händer efter att receptet är utfärdat innebär en stor osäkerhet (Hendin \& Kamisar, 2009, s. 19). Det är inte heller ett krav att patienten ska vara mentalt kompetent vid den tidpunkt den dödliga drogen intas (Hendin \& Foley, 2008) eller att ett neutralt vittne måste närvara vid dödstidpunkten. Bristen på säkerhet vid deras död utsätter patienter för risk.

Under de första tre åren efter Oregonmodellens införande framkom det i rapporter att i $59 \%$ av fallen hade patienten varit tvungen att fråga två eller fler läkare innan han eller hon fått medlet utskrivet. Efter det 
tredje året slutade denna kategori att inkluderas i de officiella rapporterna (Golden \& Zoanni, 2010). Frånvaron av ett sådant krav gör det omöjligt att veta grunderna till varför de första läkarna i dessa fall vägrade att skriva ut de dödliga doserna. Det är också omöjligt att veta hur många nekanden som skett vid patienternas första förfrågan under åren som gått sedan 2001.

2010 gjordes en revidering för att standardisera rapporteringen utifrån uppföljningsformulären. Efter revideringen inhämtas information om dödstidpunkten och omständigheter kring dödsfallet endast i de fall läkaren eller annan sjukvårdspersonal var närvarande vid dödsögonblicket. Under 2018 var antingen den receptförskrivande läkaren eller annan sjukvårdspersonal på plats vid dödstidpunkten för 65 av 168 patienter. Bland dessa individer varierade tiden för intag av drogen till dödsögonblicket från en minut till 104 timmar. Rapporterade komplikationer var få, men i de allra flesta fall (105) var de okända. Ingen rapporteras ha återfått medvetandet (Oregon Public Health Division, 2019). Av de 168 läkarassisterade självmord som skedde under 2018 saknas således rapporter om komplikationer och hur lång tid det tog innan döden inträffade i 101 fall. Detta innebär att när information om hur förloppet ter sig från det att personen intar drogen till själva dödstidpunkten inte journalförs, kan det inte ske någon eftergranskning vilket medför svårigheter att utvärdera hur dödsprocesserna har gått till.

Det är då svårt att bedöma huruvida patienterna verkligen har fått den »värdiga död» som lagens namn Death With Dignity implicerar. Att komplikationer inte rapporteras är en stor svaghet; kunskap saknas således om hur livets slut verkligen blev.

\section{2 »Det sluttande planet»}

2019 infördes ett tillägg till lagen som innebar att betänketiden avskaffades vid stor risk för snar död. Detta indikerar att en glidning mot en alltmer liberal lagstiftning har skett, i Oregon såväl som i Benelux och Kanada. Är det sannolikt att det kommer att stanna där?

När det rapporteras om risk för obehagliga komplikationer, är det då tänkbart att tillämpningen efter en eventuell legalisering glider iväg mot 
läkarinjicerade droger, det vill säga eutanasi? Både sjukvårdspersonal och förespråkare för läkarassisterat självmord har slagit fast att oralt intag av dödliga preparat ofta är ineffektivt för att generera en snabb och enkel död. Förespråkare för eutanasi menar att det bästa sättet att undvika den typ av "problem» som behandlades i föregående avsnitt är att tillåta dödliga injektioner från läkare - det vill säga att legalisera eutanasi. Precis detta framfördes i Oregon 2019 genom ett förslag till lagändring för att patienter som vill ha läkarassisterat självmord ska kunna beredas möjlighet att få hjälp med dödliga injektioner (House Bill 2217, 2017). Det kan vara svårt för samhället att stå emot utvecklingen för legalisering av eutanasi efter att man har först har brutit barriären genom att tillåta läkarassisterat självmord.

Hur länge kommer rättviseprincipen att tillåta att just patienter med outhärdligt psykiskt lidande skulle förvägras rätten till självmord? Personer med psykiskt lidande, posttraumatisk stress efter ohyggliga upplevelser i krig, våldtäktsoffer och många andra kan uppleva ett outhärdligt lidande. Patienter i sluten psykiatrisk vård ska ges tillgång bara de kan anses vara terminalt sjuka - vilket kan vara ett övertramp mot beslutsförmågan (Göransson, Malmgren \& Seidal, 2016). Legalisering av assisterat självmord betyder att en del människor som säger att de vill dö kommer att få hjälp att undvika att ta sitt liv, medan andra kommer att erhålla assistans för att begå självmord. Skillnaden mellan dessa två grupper kommer att ligga $\mathrm{i}$ deras hälsa eller funktionella status, vilket leder till ett tvådelat system som resulterar i död för den av samhället nedvärderade gruppen (Golden, 2013).

Andelen rapporterade fall i Oregon av läkarassisterat självmord kopplade till patienters ovilja att ligga familjen till last har ökat kraftigt mellan 1998 och 2018. Under perioden 2013-2017 var detta den fjärde största orsaken till att patienten ville ha läkarassisterat självmord, 54 \% angav detta som ett skäl 2018 (Oregon Public Health Division, 2019). Sannolikheten för att svårt sjuka kommer att välja assisterat självmord på grund av press utifrån är alltför stor för att bortses ifrån. Framförallt äldre personer som inte vill vara en börda för sina familjer, vilket de i realiteten i flera välfärdsstater faktiskt utgör, kan tänkas ta denna utväg. Den döende kan av tämligen rationella skäl påverkas att tro att det helt enkelt är deras skyldighet att dö. När samhällets resurser för vård och omsorg minskar ökar behovet av att anhöriga träder in och tar över vård och tillsyn av sina 
närmaste. Det kan vara en bidragande orsak till att vissa personer väljer, eller påverkas till att välja, läkarassisterat självmord.

Ett exempel kan illustrera hur bristande resurser kan vara orsak till att människor väljer att avsluta sina liv: Våren 2019 granskade FN-sändebudet Devandas-Aguilar Kanadas efterlevnad av FN-konventionen om funktionshindrades rättigheter. I Kanada förekommer det att patienter med omfattande hjälpbehov till följd av neurologiska sjukdomar som ansökt om vård istället erbjudits dödshjälp (Favaro, 2019; Saba, 2019). I ett öppet brev till Kanadas hälsominister har en grupp läkare och forskare i Quebec framfört att bristande finansiering av palliativ vård har tvingat patienter att istället ansöka om läkarassisterat självmord (Wallace \& Parent, 2019). I sin rapport framförde FN-sändebudet skarp kritik mot den inverkan som implementeringen av dödshjälpslagen har fått för funktionshindrade personer i Kanada (Devandas-Aguilar, 2019).

Det pågår en intensiv forskning avseende läkemedelsbehandling för flera allvarliga neurologiska sjukdomar, bland annat ALS. På senare tid har man också lyckats ta fram flera genmodifierande behandlingar för vissa sjukdomar som vanligtvis är förenade med omfattande funktionshinder (exempelvis spinal muskelatrofi, Duchennes muskeldystrofi, Pompes sjukdom). Det är ofta dyra läkemedel och kräver livslång behandling. Kan man vara säker på att samhället inte kommer att erbjuda dödshjälp som ersättning för andra och dyra behandlingsalternativ antingen genom att minska tillgången till dem eller göra dem mindre attraktiva?

Det är olagligt att tvinga eller att otillbörligt påverka en person att avsluta sitt liv genom dödshjälp (DWDA, 1997, section 4). Men utmaningen ligger i hur man klart ska kunna bevisa en sådan påverkan med så hög grad av säkerhet att det kan leda till att någon döms. Förbudet mot otillbörlig påverkan kan således hävdas vara en illusorisk säkerhetsmekanism.

\section{Slutsats}

Oregons lag rörande läkarassisterat självmord kallas Death With Dignity Act. En värdig död, utan svåra symptom, är vad både förespråkare och motståndare till dödshjälp i någon form önskar. 
Den palliativa vården kan inte i varje enskilt fall försäkra patienten om en helt symptomfri död, det måste man vara medveten om (se kap. 10). Och för många människor - enligt statistik från Oregon - är autonomi, viljan att ha kontroll, att inte ligga anhöriga till last så stark att de föredrar självmord framför en tid av god palliation och en naturlig död. Men är av samhället legaliserad dödshjälp svaret på denna naturliga rädsla inför slutet?

Erfarenheterna från Oregon är värdefulla när införandet av legaliserad dödshjälp diskuteras i de nordiska länderna. De visar hur svårt och krävande det är att skapa en dödshjälpslag som innehåller tillräckliga säkerhetsmekanismer för ett irreversibelt ingrepp. Det är lätt att hävda att vi, till skillnad från Oregon, är kapabla att skapa bättre och tillräckliga kontrollrutiner. I Oregon har man gjort så gott man har kunnat och ändå har man inte uppnått bättre resultat. Om Oregonmodellen introduceras i Norden måste den tävla om resurser med all annan sjukvård. Kommer vi i de av våra nordiska länder som har bristande resurser till psykiatrin att ha tillräckligt med psykiatriker för att göra ett bättre arbete än i Oregon där endast 1,2 \% får en psykiatrisk bedömning? Redan idag har vi bristande tillgång till palliativ vård i livets slutskede. Om vi inför Oregonmodellen, vilken garanti har vi för att beslutsfattarna plötsligt vill tillskapa mer resurser för att stärka den palliativa vården?

Huruvida läkarassisterat självmord i Oregon verkligen innebär en värdig död i frid och under kontroll är svårt att bedöma på grund av bristande transparens, öppenhet och den knapphändiga rapporteringen om hur patienterna verkligen dör till följd av frånvaro av externa observatörer eller läkare som övervakar vad som händer.

Vår analys av Oregonmodellen har påvisat allvarliga brister när det gäller att skydda patienter. Det som i utgångspunkten framstår som betryggande säkerhetsmekanismer visar sig vid närmare granskning vara behäftade med svagheter. Särskilt beklämmande är det bristfälliga skydd som finns för svaga och utsatta människor såsom patienter med funktionshinder eller de som lider av depression eller andra psykiska sjukdomar. Vilken utredning och behandling en enskild patient erbjuds är alltid i viss mån avhängigt av vilken läkare han eller hon möter, och konsekvenserna av detta kan vara mer eller mindre avgörande för 
patientens fortsatta hälsa. Det får allvarliga följder när den enskilde läkaren tillerkänns denna avgörande påverkan på den irreversibla åtgärden att avsluta patientens liv.

Det tydliga alternativet till införandet av läkarassisterat självmord är en helhjärtad satsning på att erbjuda en så högkvalitativ palliativ vård som möjligt. Att hjälpa patienter med smärta, illamående och andnöd med god symptomlindring, det är att ge en värdig död. Att hjälpa dem som känner hopplöshet och oro, och göra detta genom att ge god vård, värdigt bemötande och där så behövs även ge psykiatrisk behandling (se kap. 11), det är att hjälpa dem till en värdig död. Det är ett sådant samhälle vi önskar, där människor i livets slutskede får uppleva en i verklig mening värdig död.

\section{Referenser}

Association of Northern California Oncologists \& Medical Oncology Association of Southern California. (2007). Position statement on physician-assisted suicide and opposition to $A B 374$. Hämtad från https://dredf.org/assisted suicide/ Oncology\%2oStatement\%200n\%20AB\%20374\%20(Berg).pdf

Death with Dignity Act. (1997). The Oregon Death with Dignity Act. Oregon revised statute. Hämtad från http://public.health.oregon.gov/ProviderPartnerResources/ EvaluationResearch/DeathwithDignityAct/Documents/statute.pdf

Devandas-Aguilar, C. (2019). End of mission statement by the United Nations special rapporteur on the rights of persons with disabilities, Ms. Catalina DevandasAguilar, on her visit to Canada. Hämtad från https://www.ohchr.org/EN/ NewsEvents/Pages/DisplayNews.aspx?NewsID = 24481\&LangID $=\mathrm{E}$

Dore, M. (2009). 'Death with dignity': What do we advise our clients? Bar Bulletin. Hämtad från https://www.kcba.org/newsevents/barbulletin/BView aspx?Month $=05 \&$ Year $=2009 \& A I D=$ article $5 . \mathrm{htm}$

Favaro, A. (2019). Barely hanging on to life: Roger Foley shares his fight for home care with UN envoy. CTV News Canada. Hämtad från https://www.ctvnews.ca/ health/barely-hanging-on-to-life-roger-foley-shares-his-fight-for-home-carewith-un-envoy-1.4378334

Golden, M. (2013). Why assisted suicide should not be legalized. Disability Rights Education \& Defense Fund (DREDF). Hämtad från https://dredf.org/publicpolicy/assisted-suicide/why-assisted-suicide-must-not-be-legalized/

Golden, M. \& Zoanni, T. (2010). Killing us softly: The dangers of legalizing assisted suicide. Disabil Health J., 3(1), 16-30. 
Göransson, M., Malmgren, B. \& Seidal, T. (2016, 8 december). Säg nej till sluttande planet. Dagen.

Hendin, H. \& Foley, K. (2008). Physician-assisted suicide in Oregon: A medical perspective. Michigan Law Review 106(8), 1613-1640.

Hendin, H. \& Kamisar, Y. (2009). Brief amicus curiae of International Task Force on Euthanasia \& Assisted Suicide. Hämtad från https://dredf.org/wp-content/ uploads/2012/08/Amicus-brief-Baxter-FROM-ITF.pdf

House Bill 2217. (2017). Oregon legislative assembly. Hämtad från https://olis.leg. state.or.us/liz/2017R1/Downloads/MeasureDocument/HB2217/Introduced

Johansen, S., Hølen, J. C., Kaasa, S., Loge, J. H. \& Materstvedt, L. J. (2005). Attitudes towards, and wishes for, euthanasia in advanced cancer patients at a palliative medicine unit. Palliat Med., 19(6), 454-6o.

Lundgaard, H. (2019, 9 februari). Med en gin tonic og en dødelig dose hjalp Anna sin mor med å dø. Aftenposten. Hämtad från https://www.aftenposten.no/ amagasinet/1/m6mxW1/Med-en-gin-tonic-og-en-dodelig-dose-hjalp-Anna-sinmor-med-a-doe

Luthman, M. \& Ekström, A.-B. (2017). Hotet mot värdigheten - En genomgång av konsekvenserna av läkarassisterat självmord, med särskilt fokus på Oregonmodellen. Rapport 2017:1, Claphaminstitutet. Hämtad från http://www. claphaminstitutet.se/wp-content/uploads/2017/03/1-2017-L\%C3\%A4kasssj\% $3 \%$ A4lvmord-pdf.pdf

Oregon Public Health Division. (2019). Oregon Death with Dignity Act: 2018 data summary. Hämtad från https://www.oregon.gov/oha/PH/ PROVIDERPARTNERRESOURCES/EVALUATIONRESEARCH, DEATHWITHDIGNITYACT/Documents/year21.pdf

Ottosson, J.-O. (2009). Läkarassisterat självmord risk för avhumaniserad vård. Läkartidningen, 106(1-2), 9. Hämtad från http://www.lakartidningen.se/ Functions/OIdArticleView.aspx?articleId=11113

Pahlén, M. T. (2018) Cancer är inte längre en dödsdom. Forskning.se. Hämtad från https://www.forskning.se/2018/10/22/36601/

Saba, P. (2019). Assistance in living: Not assisted suicide. Letter to future Prime Minister of Canada from Canadians with disabilities. Hämtad från https:// elderadvocates.ca/assistance-in-living-not-assisted-suicide/

Senate Bill 579. (2019). Oregon legislative assembly. Hämtad från https://olis leg.state.or.us/liz/2019R1/Downloads/MeasureDocument/SB579/ Introduced

Statens medicinsk-etiska råd. (2017). Rapport 2017:2: Dödshjälp. En kunskapssammanställning. Hämtad från http://www.smer.se/wpcontent/uploads/2017/11/Smer-2017.2-D\%C3\%B6dshj\%C3\%A4lp-Enkunskapssammanst $\% \mathrm{C}_{3} \% \mathrm{~A}_{4}$ llning.pdf 
Wallace, J. \& Parent, L. (2019). Bill 20 undermines disability rights and access to care: An open letter to Gaétan Barrette, Quebec Health Minister. Hämtad från http://mia.mobilities.ca/criticaldisability/bill-20-open-letter/

Warnock, M. (2008). A duty to die? Omsorg, 25(4), 3-5. Hämtad från http:// eideforlag.no/filarkiv/Mary\%2oWarnock.pdf

\section{Ordforklaringer}

beslutsformåga: beslutningskompetence/-anse $(\mathrm{D} / \mathrm{N})$

bristfällig: mangelfuld/mangelfull $(\mathrm{D} / \mathrm{N})$

drabbas: rammes $(\mathrm{D}, \mathrm{N})$

erhåller: mottager (D), mottar $(\mathrm{N})$

förespråkare: fortalere (D), forkjempere (N)

förfrågan: forespørgsel/forespørsel $(\mathrm{D} / \mathrm{N})$

förlust: tab/tap (D/N)

förvägras: nægtes/nektes (D/N)

knapphändiga: sparsomme $(\mathrm{D}, \mathrm{N})$

livshotande: livstruende $(\mathrm{D}, \mathrm{N})$

omdöme: dømmekraft (D, N)

omedvetet: ubevidst/ubevisst (D/N)

omhändertagas: håndteres $(\mathrm{D}, \mathrm{N})$

oroskällan: bekymring /D, N)

outhärdlig: uud-/uutholdelig $(\mathrm{D} / \mathrm{N})$

utvärdering: evaluering $(\mathrm{D}, \mathrm{N})$

rörande: vedrørende $(\mathrm{D}, \mathrm{N})$

självmordsbenägna: selvmordstruede $(\mathrm{D}, \mathrm{N})$

skede: stadium $(\mathrm{D}, \mathrm{N})$

skyldighet: forpligtelse/forpliktelse (D/N)

sluten: lukket $(\mathrm{D}, \mathrm{N})$

sluttande plan: glidebane (D), skråplan $(\mathrm{N})$

syftet: formål(et) $(\mathrm{D}, \mathrm{N})$

tillämpas: anvendes $(\mathrm{D}, \mathrm{N})$

äventyra: sætte på spill (D), true (N)

åtgärden: handlingen (D), tiltaket (N) 


\title{
KAPITTEL 15
}

\section{Er det mulig å lage en entydig, rettferdig og forsvarlig dødshjelpslov?}

\author{
Morten A. Horn
}

Oslo universitetssykehus

\begin{abstract}
The public debate about assisted dying follows several tracks. The most important political question is whether euthanasia should be legalised, and if so how it should be delimited, regulated and controlled. Is it even possible to create a law that delineates when assisted dying should be allowed and when it should be prohibited, in a clear, fair and safe way? This chapter proposes criteria that can be used to design an assisted dying law, and discusses how existing laws can be evaluated based on the criteria. Particular emphasis is placed on the recent Canadian assisted dying legislation, which, in the author's view, has failed in all three areas.
\end{abstract}

Keywords: assisted dying, Canada, justice, legislation, safety

I den norske debatten kan man høre at dødshjelp «selvsagt» bør være lov, fordi det handler om individets liv, individets frihet - det er som om selve utgangspunktet er at dødshjelp burde vært tillatt for lengst. Slik kunne det selvsagt vært, i en tenkt rettsstat. Men slik er det ikke i de nordiske landene.

Spørsmålet vi står overfor, er om dødshjelp skal bli tillatt, og hvordan en lov skal trekke grensen mellom lovlig og ulovlig dødshjelp. Jeg vil innledningsvis diskutere hvorfor en slik grensedragning må være eksplisitt. I kapitlets hoveddel argumenterer jeg for at avgrensningen må være entydig, rettferdig og forsvarlig. Til slutt vil jeg vurdere den nyutviklede

Sitering av denne artikkelen: Horn, M. A. (2020). Er det mulig å lage en entydig, rettferdig og forsvarlig dødshjelpslov? I M. A. Horn, D. J. H. Kleiven \& M. Magelssen (Red.), Dødshjelp i Norden? Etikk, klinikk og politikk (Kap. 15, s. 291-309). Oslo: Cappelen Damm Akademisk. https://doi.org/10.23865/noasp.96.ch15. Lisens: CC BY 4.0. 
kanadiske dødshjelpsmodellen opp mot disse egenskapene som jeg mener en dødshjelpslov bør ha. Jeg skisserer også helt kort hvordan dødshjelpslovene i Benelux-landene, Oregon og Sveits kan vurderes opp mot kriteriene. $^{1}$

\section{Hvorfor må en dødshjelpslov være eksplisitt?}

Dette kapitlet tar utgangspunkt i dagens situasjon i Norge, der dødshjelp er eksplisitt forbudt (se kap. 3). Straffelovens $\$ 276$ forbyr eutanasi, $\$ 277$ forbyr assistanse til selvmord, og $\$ 278$ forbyr barmhjertighetsdrap. I tillegg pålegger straffelovens $\$ \$ 287-288$ alle borgere en plikt til å hjelpe mennesker i akutt livsfare, og nedlegger forbud mot å hensette en person i hjelpeløs tilstand. Dersom dødshjelp skulle bli tillatt i Norge, ville det kreve enten en endring av disse paragrafene i straffeloven eller en egen paragraf som hjemlet unntak fra loven på disse områdene. En åpning for dødshjelp ville dessuten kunne komme i konflikt med lover som regulerer helsepersonells plikter, som for eksempel hjelpeplikten i den norske helsepersonellovens $₫ 7$.

I andre land, som Sverige, der assistanse til selvmord ikke er eksplisitt forbudt ved lov (se kap. 3), ville det kanskje være mulig å innføre varianter av dødshjelp uten å endre straffeloven. Man kunne bare innføre det som et medisinskfaglig fundert tilbud. Men dette ville ikke gi det som mange har etterlyst: en velavgrenset og velregulert dødshjelpspraksis under offentlig kontroll, med robuste seleksjons- og kontrollmekanismer.

Det kan virke selvsagt at dødshjelp - og da især eutanasi, der en person regelrett tar livet av en annen person, etter dennes oppfordring og samtykke - må være forankret i loven. Imidlertid finnes det eksempler på at dødshjelp har blitt omdefinert fra å være en drapshandling, regulert av straffeloven, til å bli en form for medisinsk-faglig behandling ved livets slutt. Den kanadiske provinsen Quebec åpnet alt i 2015 for dødshjelp, men da som del av den provinsielle helselovgivningen, uten at den føderale straffeloven ble endret. Dette førte til en juridisk disputt (Peritz, 2015),

Kapitlet er en betydelig omarbeidet versjon av en tekst publisert i festskriftet til Aslak Syse (Horn, 2016), med forlagets tillatelse. 
som ble passé da Canada året etter legaliserte dødshjelp på føderalt nivå (se under).

Gjentatte spørreundersøkelser (se bl.a. Magelssen, Supphellen, Nortvedt \& Materstvedt, 2016) viser at et klart flertall av nordmenn er positive til legalisering av dødshjelp. Lignende holdninger ses i de andre nordiske landene (se kap. 3). Selv om spørreundersøkelsene i seg selv kan diskuteres, er det liten tvil om at brede lag av folket ønsker at dødshjelp skal være tillatt. Samtidig forutsettes det oftest i det offentlige ordskiftet at dødshjelpen skal skje under streng kontroll, at den bare skal gis til utvalgte pasientgrupper, og at ingen skal bli tatt livet av mot sin vilje. Mange er opptatt av at det ikke må skje en utglidning.

Hvis vi skal følge folkets vilje og legalisere dødshjelp, er det da mulig å lage en dødshjelpslov som oppfyller disse forutsetningene? Hva sier erfaringene fra land som har innført dødshjelp? Kan dødshjelp i det hele tatt legaliseres - på en entydig, rettferdig og forsvarlig måte?

\section{Avgrensning av dødshjelp}

\subsection{Behovet for entydig avgrensning}

En dødshjelpslov må gi en entydig avgrensning av i hvilke situasjoner, for hvilke personer, med hva slags dødshjelpere og gjennom hvilke prosedyrer dødshjelp skal være tillatt. Entydighet er viktig for alle involverte parter: myndighetene, dødshjelperne, de som ønsker hjelp til å dø, og de som står igjen.

Myndighetene skal straffeforfølge tilfeller av illegale drapshandlinger eller illegal hjelp til selvmord. Samtidig må hensikten med en dødshjelpslov være at legitime dødshjelpshandlinger ikke straffes eller unødig hindres eller stigmatiseres (formålet er å gi sterkt lidende mennesker en skånsom og verdig utgang av livet). Loven må derfor være et praktisk anvendbart redskap som tydelig skiller mellom når det har skjedd en straffbar handling, og når det har funnet sted legitim dødshjelp. Loven må være så robust og veldefinert at den tåler prøving i rettsapparatet, slik at overtredelser faktisk kan dømmes. Er loven for vag, vil ikke myndighetene ha noe klart grunnlag å dømme lovovertredere på, enn si definere hva som er en lovovertredelse. 
Dødshjelperne - typisk legene - har også behov for entydig avgrensning av når dødshjelp er berettiget. Dels for å kunne tilby dødshjelp til den rette pasientgruppen, for det er ikke medisinsk selvinnlysende hvilke pasienter som bør kunne få dødshjelp. Dels av hensyn til legene: Beslutningen om å ta et menneskes liv kan veie tungt på legens skuldre (van Marwijk, Haverkate, van Royen \& The, 2007; Kelly, Handley, Kissane, Vamos \& Attia, 2019). Jo mer diffus lovgiver er, og jo mer som overlates til legens skjønn, desto tyngre kan beslutningen oppleves. Legen trenger også å vite - før handlingen - hvordan myndighetene vil reagere. Det er nødvendig for legens rettssikkerhet, men også for å oppnå fullgod rapportering: Leger vil kunne kvie seg for å rapportere dødshjelpshandlinger dersom de er usikre på om de kan bli straffet for det. Ikke minst er det avgjørende for å sikre at også pasienter som befinner seg i gråsonen, men likevel er blant dem som «bør» få hjelp til å ta sitt liv, får denne muligheten: En vag lov kan føre til at legene blir usikre og overforsiktige (Hasham, 2017).

Personene som ønsker dødshjelp, typisk pasienter, er også avhengige av at en lov klart definerer hvem som skal få hjelp til å dø, og hvem som skal få avslag. De førstnevnte må ha sikkerhet for at det virkelig er korrekt at livet deres skal avsluttes. De sistnevnte vil måtte leve videre i et liv preget av (i deres egne øyne) uakseptabel, uutholdelig lidelse, og alternativt begå selvmord for egen hånd med mer brutale metoder. Pasientene vil kunne møte leger med ulik grunnholdning til dødshjelp og ulikt syn på enkeltsaker. Er legens «nei» bare et uttrykk for denne enkelte legens holdning, eller er det pasienten selv som ikke oppfyller kriteriene? Vil det være noen hjelp i å lete videre etter en mer sympatisk innstilt lege? Også de etterlatte etter dødshjelp vil ha behov for å kunne vite, og forstå, hvorvidt det som skjedde, var i tråd med lovens krav (Roest, Trappenburg \& Leget, 2019). Dette vil være særlig viktig dersom de etterlatte er innbyrdes uenige om hvorvidt dødshjelp var det rette valget.

\subsection{Behovet for rettferdighet}

For mange vil det være selvsagt at en lov må oppleves som rettferdig. I dødshjelpsdebatten har jeg imidlertid møtt holdninger om det 
motsatte. Noen debattanter påpeker at mange lover innebærer en avgrensning som noen kan oppleve som urettferdig (som et eksempel, se Moen \& Sterri, 2019, s. 99-101). Et enkelt eksempel er 18-årsgrensen for førerkort: Hvor er rettferdigheten i at en umoden 18-åring får kjøre bil, mens en moden og dyktig 17²/2-åring ikke får lov? Hvorfor er abort selvbestemt til utgangen av uke 12, mens man senere i svangerskapet må få godkjenning av en nemnd? Dette er for så vidt gode innvendinger - samtidig som de i realiteten understreker poenget med at en lov bør være rettferdig, eller så må en urettferdighet i loven ha en forståelig begrunnelse.

Et hovedproblem med vilkårlige avgrensninger av helseytelser oppstår dersom de ikke følger en form for «historisk», «naturlig» eller «biologisk» linje. Det er lettere å oppnå aksept for vilkårlige skillelinjer dersom disse følger et slags resonnement, en naturlig demarkasjon, eller en etablert og mye brukt merkestein.

Det er mulig å vedta en urettferdig lov - for eksempel en lov som innvilger dødshjelp kun til pasienter med kreftdiagnose, eller en aldersgrense ved pensjonsalderen (se kap. 12). Men en urettferdig lov vil, allerede fra den vedtas, være ustabil. Den vil raskt kunne utfordres av personer som faller utenfor lovens kriterier, og som stiller spørsmål ved de avgrensninger lovgiver har vedtatt. Jo mer vilkårlig avgrensningen er, jo mindre forståelig framstår den, og desto svakere vil loven stå. Presset for en utvidelse av loven vil kunne bli sterkt - med et kraftig og ensidig medietrykk (Staff-Poulsen, 2019). Alternativt vil en opplevd urettferdighet i loven føre til at dens strenge krav ikke overholdes i praksis: Leger og andre aktører vil kunne fortolke loven etter eget hode, slik at det oppstår et misforhold mellom lovverk og praksis.

\subsection{Behovet for forsvarlighet}

Forsvarlighet har to aspekter som er relevante for en dødshjelpslov. Det ene handler om enkeltindividene - i hvilken grad loven beskytter pasienten, legen og andre som er direkte involvert i dødshjelpshandlingen. Det andre handler om konsekvensene av en legalisering på samfunnsnivå, der det kan være risiko for en «skråplanseffekt». 
Noe av poenget med lovregulering av dødshjelp kan være å bringe en illegal praksis inn i ordnede former (Ofstad, 2009). Klarere kriterier og bedre kontroll foreslås for å motvirke misbruk og overgrep. Men i så fall må en dødshjelpslov nettopp inneholde robuste kriterier og kontrollsystemer, for å sikre at pasienter ikke presses til å ta sitt liv, eller at uvørne leger misbruker den adgangen til å ta liv som loven gir dem. Forsvarlighet er avgjørende for den som skal motta dødshjelp, for de pårørende, for den som utfører dødshjelpen, og for samfunnet som skal føre kontroll med praksisen.

\subsubsection{Kontrollsystemer}

En dødshjelpslov må bygge på et system for gransking. I den ene enden kan man trekke alle slike saker inn for retten, hvor dommerne kan enten frikjenne eller idømme mild straff dersom dødshjelpshandlingen er utført i henhold til lovens krav. I den andre enden kan man nøye seg med å kreve at handlingen journalføres på linje med annen medisinsk behandling, og så granskes dersom noen oppdager misligheter.

Overordnet må en gransking foregå enten forskuddsvis eller etterskuddsvis. Det vanlige i land som har legalisert dødshjelp, er å granske i etterkant av handlingen. Imidlertid er det problematisk å betegne en slik løsning som «forsvarlig». Pasienten vil da være tatt av dage, og loven maktet ikke å forhindre det. Det viktigste vitnet - pasienten selv - vil være død, og kan ikke bidra med informasjon. Et «livstestament» («advance directive») kan kompensere for dette, men gir ingen mulighet til kontrollspørsmål eller supplerende undersøkelser. Et «forsvarlig» granskingssystem bør prinsipielt sett plasseres forut for dødshjelpen. Dette ville også være best for rettssikkerheten til legen, som ellers kan risikere å utføre en kriminell handling «i god tro», for deretter å bli funnet skyldig i lovbrudd og straffet.

\subsubsection{Samfunnseffekter}

I en del land hvor dødshjelp debatteres, er talsmenn for funksjonshemmedes foreninger (se f.eks. Campbell, 2019) bekymret for at personer som dem vil oppleve at retten til å dø vil bli til en plikt til å velge døden (se Warnock, 2008, for en drøfting av om det kan være en moralsk plikt til å dø). Det å fortsette å leve, i visshet om at man utgjør en byrde for sine 
omgivelser, kan bli til et valg man må gjøre og stå ansvarlig for - i en situasjon der staten har åpnet for og lagt til rette for at man kan fjerne byrden og seg selv gjennom legal dødshjelp (se også kap. 5).

I dag framstår nok dette som en uhørt problemstilling. Spørsmålet er hvordan det vil fortone seg i et samfunn der dødshjelp er institusjonalisert og normalisert (Ross, 2015; Aviv, 2015). Jo vanligere det blir at for eksempel eldre mennesker velger å ta sitt liv, jo sterkere blir kontrasten til de som avstår fra dette valget: De som takker nei til en livsavslutning som ville skåne deres pårørende og dessuten allokere knappe helseressurser til mer verdig trengende (se Vigeland, 2009). En dødshjelpslov som skal være forsvarlig, vil måtte hanskes med denne muligheten for at mennesker kan føle seg presset til å ta sitt liv fordi de utgjør en byrde for andre.

Legalisering av dødshjelp vil kunne ha store konsekvenser for legepasient-forholdet og legerollen (se kap. 9). På samfunnsnivå vil utfordringen særlig være å finne en balanse mellom hensynet til to grupper med motstridende interesser: Pasienter som ønsker hjelp til å dø, der de bor og når de ønsker det, og leger som ikke ønsker å bruke sin legegjerning til slikt arbeid.

\subsubsection{Skråplanseffekt og verdiglidning}

Det å legalisere dødshjelp vil kunne få samfunnsmessige konsekvenser, særlig i form av det som kalles «skråplanseffekten». Skråplansargumentet kan bli latterliggjort i det offentlige ordskiftet, det kan bli framstilt som at man tror alt vil gå utforbakke: Hvis vi legaliserer dødshjelp til terminalt syke kreftpasienter i dag, vil vi i morgen ta livet av pasienter med demens for å spare penger. Dette er etter mitt syn en forvrengning av argumentet. Essensen i argumentet er at hvis vi (for eksempel gjennom lovendringer) åpner for handlinger som i dag er marginalt akseptable, vil i neste omgang disse handlingene ligge innenfor det normale. Slik vil våre felles verdier i samfunnet endre seg - utsettes for en glidning -, og med tiden vil ting som er utenkelige i dag, kunne framstå som en logisk konsekvens av samtidens verdisett.

Uttrykket «skråplanseffekt» gir en klar assosiasjon til en utvikling der ting går utforbakke, til noe negativt. Men en gradvis utvidelse av dødshjelpen, til å inkludere stadig større grupper, kan også ses på som noe positivt. For noen vil en slik prosess være den riktige og forsvarlige måten 
å introdusere dødshjelp i et samfunn på: Starte med en begrenset målgruppe, og så utvide tilbudet etter hvert som vi får erfaring med og blir trygge på metoden. Derfor er det krevende å diskutere offentlig om en lov kan gi en skråplanseffekt. Det vil avhenge av debattantens eget syn på dødshjelp om man mener en slik utvikling er bra eller dårlig.

Den norske filosofen Lars Johan Materstvedt har introdusert idéen om at legalisering av dødshjelp vil medføre institusjonalisering av dødshjelpen, og at dette i sin tur vil føre til normalisering av det som opprinnelig var en eksepsjonell praksis (Materstvedt, 1998). Min versjon av dette argumentet er at det å fjerne lovforbudet mot dødshjelp kan iverksette en verdiglidning, og at denne verdiglidningen i neste omgang vil kunne svekke vår motstandskraft mot stadig nye utvidelser av loven - potensielt langt utenfor det som var vår intensjon da loven ble vedtatt.

Jeg mener at en slik verdiglidning er en mulig risiko vi løper ved å legalisere dødshjelp til utvalgte pasientgrupper, og at en dødshjelpslov derfor kan ha en iboende svakhet: Selv om vi forsøker å lage en snever lov som skal løse noen påtrengende saker, som medieomtalte tilfeller av håpløs lidelse, kan lovendringen utløse prosesser og krefter for utvidelse som vi ikke nødvendigvis vil klare å kontrollere.

Faktorer ved en dødshjelpslov som kan fremme eller motvirke en skråplanseffekt, er, som nevnt i dette kapitlet, entydig avgrensning, rettferdighet og kontrollordninger. Dersom loven er vagt avgrenset, vil det være mulig med en betydelig glidning i praksis, og dermed etablering av nye normer, uten at loven i seg selv trenger å endres. Dersom loven etablerer dødshjelp som et urettferdig tilbud til kun en snever gruppe pasienter, vil dette medføre et press om utvidelse. Dersom kontrollsystemene er svake, vil aktørene kunne utvide praksis i takt med at verdiene stadig endrer seg. Et aspekt ved forsvarligheten av en dødshjelpslov er lovens evne til å motstå en skråplanseffekt.

\section{Hvordan presterer eksisterende dødshjelpsmodeller?}

Jeg har nå diskutert tre vurderingskriterier for en god dødshjelpslov: Den må gi en entydig avgrensning, den må være rettferdig, og den må 
være forsvarlig i praktisk bruk. Dette avsnittet ser nærmere på hvorvidt utvalgte dødshjelpslover i andre land oppfyller disse kriteriene.

De såkalte «Benelux»- og «Oregon»-modellene for dødshjelpslegalisering er beskrevet i detalj i kap. 13 og 14. Den sveitsiske modellen for dødshjelp er mye omtalt i mediene grunnet «dødshjelpsturismen» til Dignitas-, Exit- og Lifecircle-klinikkene. Men som modell for andre land er Sveits dårlig egnet, siden landet ikke har noen egen dødshjelpslov. Dødshjelp er nærmest «tillatt» en passent, fordi uegennyttig assistanse til selvmord er unntatt for straff. For en beskrivelse av det juridiske grunnlaget for dødshjelp i Sveits, se Mauron (2015).

\subsection{Erfaringen fra Canada}

\subsubsection{Legaliseringsprosessen}

Den kanadiske modellen er derimot av stor interesse - ikke minst for de nordiske landene: Canada har, i likhet med våre land, inntil nylig holdt fast ved et dødshjelpsforbud. Canada ligner også på de nordiske landene når det gjelder samfunnsmodell og geografiske utfordringer. Landets erfaring kan lære oss noe om hvordan en politisk legaliseringsprosess kan foregå, og hvilke konsekvenser dette kan få for utformingen av en dødshjelpslov.

Canadas legalisering av dødshjelp har en unik bakgrunn, idet den springer ut av menneskerettslige forhold: Det var ikke politikerne, men landets høyesterett, som i 2015 (Carter-dommen) besluttet at dødshjelp i noen former måtte være tillatt. Høyesterett mente at et totalforbud mot dødshjelp krenket borgernes rettigheter etter det kanadiske charteret. Dette i kontrast til situasjonen i Europa, der menneskerettsdomstolen i Strasbourg i Diane Pretty-dommen slo fast at et forbud mot dødshjelp ikke er i strid med menneskerettene. I foregangslandet Nederland var det heller ikke pasientrettigheter som motiverte domstolenes aksept for dødshjelp: Snarere var det en anerkjennelse av at legen sto overfor to motstridende forpliktelser - hensynet til loven og hensynet til den lidende pasienten -, og at dette kunne brukes som et forsvar for legens handlinger (se kap. 13).

Canadas høyesterett ga lovgiver en kort tidsfrist for å utarbeide en lov som skulle tillate dødshjelp til: 
... a competent adult person who clearly consents to the termination of life and has a grievous and irremediable medical condition, including an illness, disease or disability, that causes enduring suffering that is intolerable to the individual in the circumstances of his or her condition. (Supreme Court of Canada, 2015)

Da det liberale partiet i Canada samme år fikk rent flertall i parlamentet, ble dette omsatt i en lov vedtatt i juni 2016 (Justice Laws Website, 2016). Loven etablerer et unntak fra straffelovens forbud mot drap og hjelp til selvmord, gitt at den som mottar dødshjelp, er voksen ( $\geq 18$ år) og beslutningskompetent, har avgitt informert samtykke til dødshjelp og oppfyller et sett med medisinske kriterier. Disse er gjengitt i tabell 1, med forfatterens kommentarer ut fra hvordan kriteriene oppfyller kravet til entydig avgrensning.

Tabell 1. De medisinske kriteriene for dødshjelp i den kanadiske loven av 2016, med forfatterens kommentarer.

\begin{tabular}{|c|c|c|}
\hline & Lovens krav & Kommentar \\
\hline Tilstand & $\begin{array}{l}\text { Serious illness, disease or } \\
\text { disability. }\end{array}$ & Ikke avgrenset til somatisk lidelse. \\
\hline Uhelbredelig & $\begin{array}{l}\text { Must be in an advanced state that } \\
\text { cannot be reversed. }\end{array}$ & $\begin{array}{l}\text { Ikke definert nærmere, men det } \\
\text { presiseres at man ikke trenger å } \\
\text { være i en terminalfase. }\end{array}$ \\
\hline $\begin{array}{l}\text { Lidelsestrykk og } \\
\text { lindringsmuligheter }\end{array}$ & $\begin{array}{l}\text { Must experience unbearable } \\
\text { physical or mental suffering (...) } \\
\text { that cannot be relieved under } \\
\text { conditions that patient considers } \\
\text { acceptable. }\end{array}$ & $\begin{array}{l}\text { Uutholdelig lidelse som definert } \\
\text { av pasienten. Pasienten avgjør } \\
\text { om han vil akseptere eller forsøke } \\
\text { lindrende tiltak. }\end{array}$ \\
\hline Forventet levetid & $\begin{array}{l}\text { Must be at a point where natural } \\
\text { death has become reasonably } \\
\text { foreseeable. }\end{array}$ & $\begin{array}{l}\text { Ikke definert nærmere hva som } \\
\text { ligger i «reasonably foreseeable } \\
\text { death»; det spesifiseres at man ikke } \\
\text { trenger å ha en dødelig sykdom. }\end{array}$ \\
\hline Metode & Medical Aid in Dying (MAiD) & $\begin{array}{l}\text { Omfatter både eutanasi og } \\
\text { legeassistert selvmord, i praksis } \\
\text { nesten bare eutanasi. }\end{array}$ \\
\hline
\end{tabular}

\subsubsection{Manglende avklaringer}

Det er verd å merke seg at loven er uklar på hva som ligger i at døden er «reasonably foreseeable». Dette er intendert: Loven skal være vag på dette punktet, for å gi leger (og det som i Canada kalles «nurse practitioners»; 
tilsvarer det som i Norge nå introduseres som «avansert klinisk sykepleie» (AKS)) fleksibilitet i utøvelsen av dødshjelpen (Government of Canada, 2016). Loven utelukker ikke dødshjelp på grunnlag av ren psykisk lidelse, så sant kriteriet om «reasonably foreseeable death» kan anses som oppfylt, men har så langt blitt tolket restriktivt på dette feltet (dette kan nå bli utvidet, se CBC Radio, 2020). Loven krever ikke at den medisinske grunntilstanden i seg selv skal være dødelig. Dette ville ha vært rart ettersom pasienten som fikk høyesteretts medhold i Carter-dommen, led av smertefull, men ikke dødelig, spinal stenose. Loven åpner ikke for dødshjelp til mindreårige ( $<18$ år) eller til personer uten samtykkekompetanse. Men i forbindelse med lovgivningsprosessen påla parlamentet regjeringen å utrede utvidelse av loven til å omfatte «competent minors», og dødshjelp på grunnlag av forhåndserklæring («advance directives») samt til pasienter med ren psykiatrisk begrunnelse for dødshjelpsønsket. The Council of Canadian Academies leverte i 2018 tre rapporter om dødshjelp for disse tre gruppene (Council of Canadian Academies, 2018). Utredningen avdekket framfor alt ulike oppfatninger og manglende evidensgrunnlag, og ga ingen klar retning for videre lovendring.

\subsubsection{Loven i praksis}

I årene som er gått siden dødshjelp ble legalisert i Canada, har forekomsten økt raskt, i den grad at det har overrasket foregangsmannen, Quebecs helseminister Gaétan Barette (Plante, 2016). Per april 2019 har det vært minst 6700 dødshjelpstilfeller i Canada. Dette utgjør over $1 \%$ av alle dødsfall, men tallene er usikre og omstridte (Schadenberg, 2019).

Det har vært flere rettssaker der pasienter har utfordret den restriktive tolkningen av begrepet «reasonably foreseeable death». I en banebrytende rettssak fra provinsen Alberta fikk en 77 år gammel kvinne med artrose (slitasjegikt) rettens medhold i at hun kvalifiserte for dødshjelp. Flere leger hadde vegret seg for å yte dødshjelp til henne, fordi de var usikre på om hennes død var «rimelig forutsigbar» (Hasham, 2017). Fortsatt pågår det saker i rettssystemet for å få avklart hva som kan tolkes inn i begrepet. Striden bunner i at høyesterett, i Carter-dommen, ikke hadde 
som kriterium at pasienten skulle være døende. Det er derfor et spørsmål om også 2016-loven er i strid med charteret.

Det har hittil ikke vært åpnet straffesak mot leger som feilaktig har utført dødshjelp. Men det er verd å merke seg at den kanadiske loven gjør klart at leger og sykepleiere som bryter loven, ikke skal straffes, dersom de handler i god tro. Derfor er det uklart hva som skal til for å domfelle helsepersonell som handler i strid med lovens krav.

Innføringen av dødshjelp i Canada har avdekket problemer med tilgjengelighet av helsetjenester. Quebecs College of Physicians hevdet i 2018 at mangel på palliativt tilbud og omsorgstjenester drev pasienter til å be om dødshjelp i stedet (CBC News, 2018). Samtidig er det utfordringer med å oppnå tilgang til dødshjelp for pasienter som ønsker det. Den kanadiske legen Ellen Wiebe er blitt kjent som dødshjelpslege, og kontaktes av pasienter som ikke får hjelp av sin egen lege (Jacobsen, 2018). Det har vært flere saker der sykehus og pleieinstitusjoner har nektet leger å utføre dødshjelp i sine lokaler, slik at pasienter har måttet flytte på seg for å få hjelp til å dø. Retten til å reservere seg mot å yte dødshjelp har kommet under press (Cousins \& Jones, 2020). Det kanadiske parlamentet har siden 2018 debattert en lov som gir leger reservasjonsrett; den er ennå ikke ferdig behandlet. Den kanadiske legeforeningens policy er at leger som ikke selv vil yte dødshjelp, plikter å viderehenvise pasienter som ber om dette, samt å gi full informasjon om dødshjelp og stille pasientjournal til rådighet for dette formålet (Canadian Medical Association, 2017).

\subsubsection{Evaluering av den kanadiske dødshjelpsloven}

Vurdert opp mot kriteriene for en god dødshjelpslov jeg har trukket opp i dette kapitlet, framstår Canadas lov som svak på alle punkter: Avgrensningen er med hensikt gjort vag, noe som overlater avgrensningen til legene og deres skjønn, åpner for variabel praksis og gjør det vanskelig å si hva som er innenfor eller utenfor lovens krav. Dette har resultert i både rettssaker og frustrasjon i offentligheten. Når man leser kanadiske aviser, får man inntrykk av at loven oppfattes som urettferdig, særlig fordi «mature minors», pasienter med psykiske lidelser eller pasienter med demens ikke får hjelp til å dø. Kravet om kort forventet levetid kommer i konflikt med høyesteretts resonnement om at et urimelig forbud mot 
dødshjelp kan «tvinge» pasienter som ønsker å framskynde døden, til å ta sitt eget liv på brutalt vis. Loven baserer seg på etterskuddsvis (innen 30 dager) innrapportering av dødshjelpen fra legen/sykepleieren via et nettbasert rapporteringsskjema. Pasientjournal, eller vurderingen fra lege nr. 2, trenger ikke å vedlegges. Nyhetssaker i kanadiske medier har vist hvordan det vage lovverket har blitt tolket kreativt av liberale leger, noe som for så vidt er i tråd med lovgivers intensjon. Likevel er det vanskelig å forstå hvordan den kanadiske dødshjelpsloven kan betraktes som en forsvarlig løsning på høyesteretts utfordring: Det å legalisere dødshjelp til visse personer, samtidig som man skal ivareta hensynet til personer som ikke skal få hjelp til å dø.

\subsection{Hvordan presterer dødshjelpslovene?}

Innenfor rammen av dette kapitlet lar det seg ikke gjøre å gjennomføre en grundig analyse av hver av de eksisterende dødshjelpslovene verden over som tjener som mulige modeller for en nordisk dødshjelpslov. Basert på min kunnskap om de viktigste dødshjelpsmodellene - «Beneluxmodellen» (se kap. 13), «Oregon-modellen» (se kap. 14), den sveitsiske modellen (ikke omtalt i detalj i denne boka, men se Mauron, 2015) og erfaringen fra Canada - forsøker jeg i tabell 2 summarisk å vurdere de viktigste modellene for dødshjelp opp mot kriteriene entydighet, rettferdighet og forsvarlighet. Plassen tillater ikke en lengre diskusjon for hvert av disse kriteriene og for hvert av landene. Det er heller ikke gitt at alle aktører ville vurdere hvert lands lovgivning likt. Heller enn å leses som den endelige analysen av for eksempel Nederlands dødshjelpslov, kan denne analysen illustrere hvordan vi i det offentlige ordskiftet om dødshjelp kan strukturere diskusjonen om konkrete lover. Dersom man har som premiss at dødshjelp i en eller annen form skal være tillatt, kan man like fullt se styrker og svakheter ved ulike måter å legalisere det på. Det å organisere disse momentene i strukturen entydighet, rettferdighet og forsvarlighet kan gjøre det lettere å diskutere et komplisert og verdiladet spørsmål. Ikke minst lovgiverne bør oppfordres til å adressere alle disse tre aspektene hvis de bestemmer seg for å lage en lov som tillater dødshjelp. 


\begin{tabular}{|c|c|c|c|c|c|}
\hline \multirow{5}{*}{ 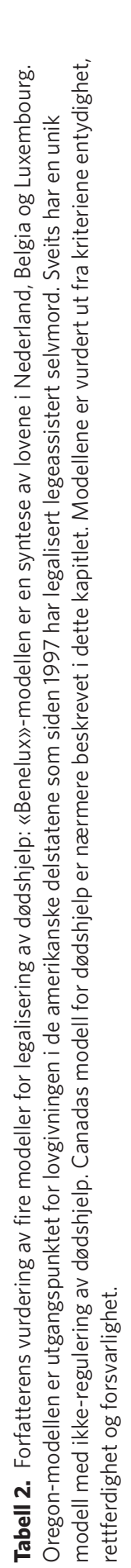 } & \multicolumn{2}{|c|}{ 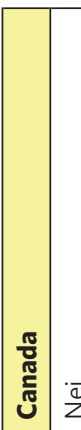 } & 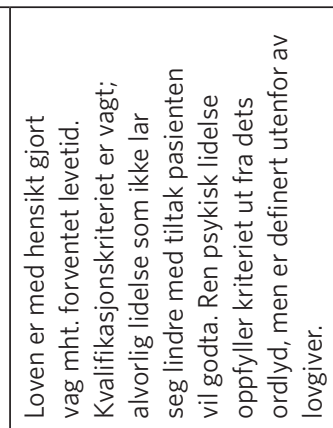 & \multicolumn{2}{|c|}{ 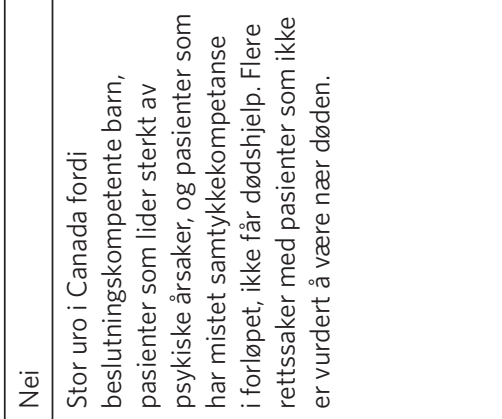 } \\
\hline & 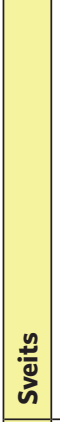 & $\overline{\mathrm{\omega}}$ & 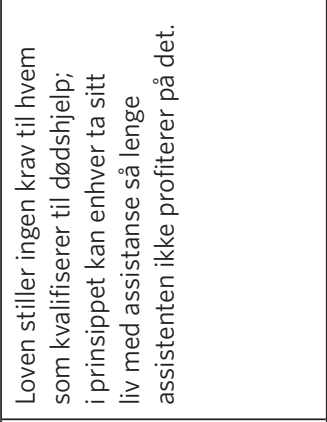 & 㱏 & 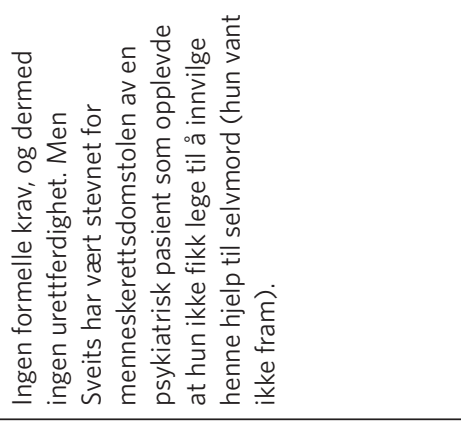 \\
\hline & 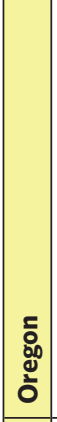 & $\begin{array}{l}\stackrel{\sim}{\tilde{O}} \\
\stackrel{\sim}{\rightleftharpoons} \\
\end{array}$ & 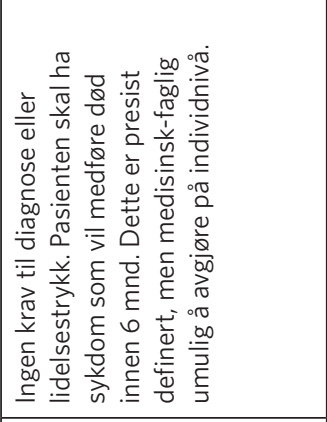 & $\overline{\bar{\omega}}$ & 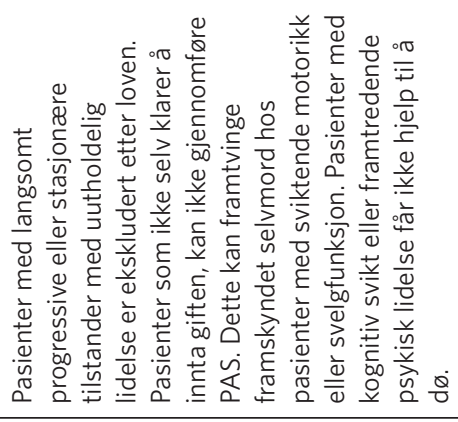 \\
\hline & 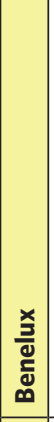 & $\overline{\underline{v}}$ & 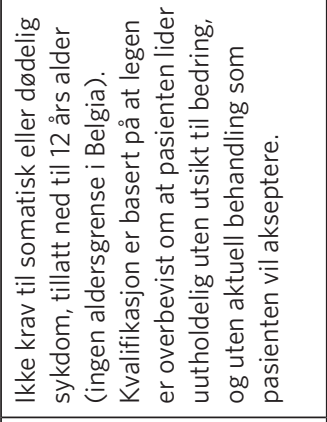 & 菏 & 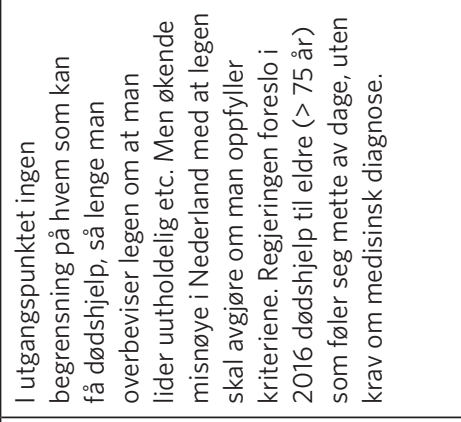 \\
\hline & 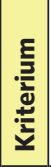 & 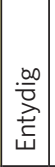 & 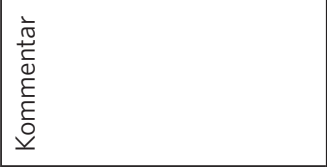 & 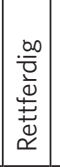 & 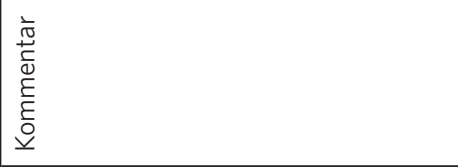 \\
\hline
\end{tabular}




\begin{tabular}{|c|c|}
\hline$\overline{\bar{\omega}}$ & 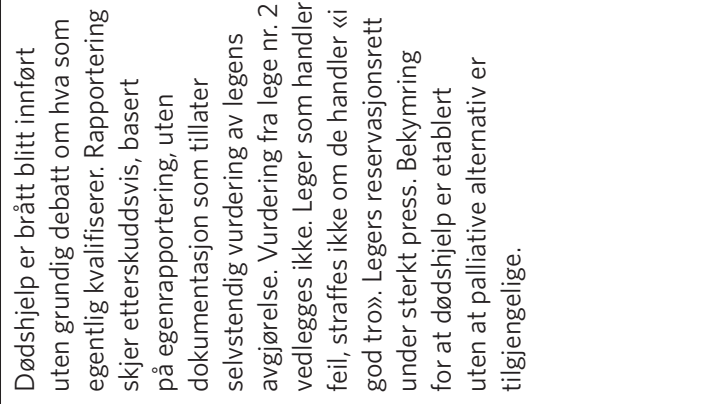 \\
\hline$\frac{\bar{\omega}}{z}$ & 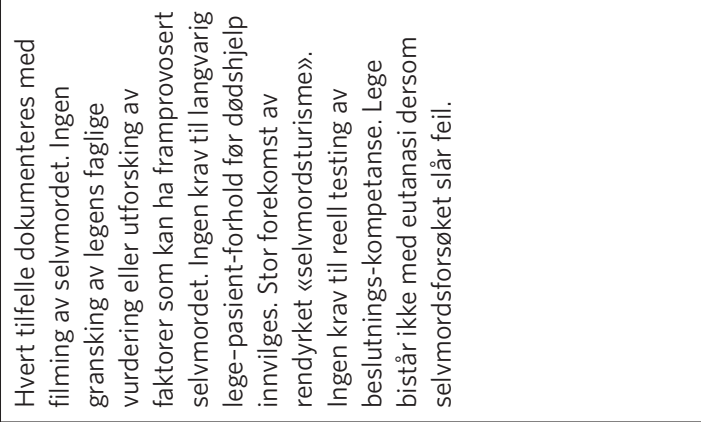 \\
\hline $\bar{c}$ & 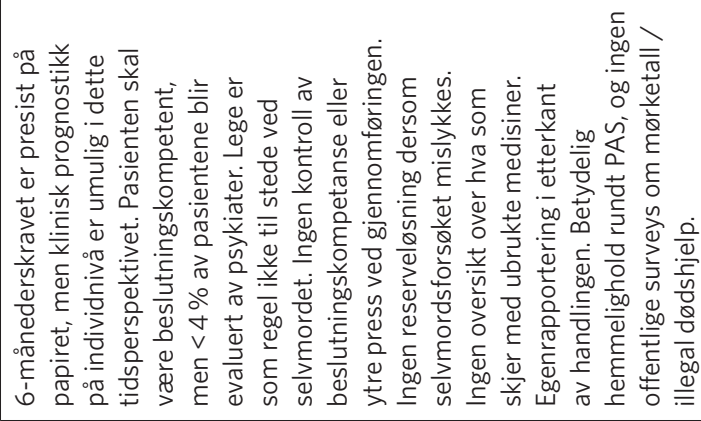 \\
\hline$\overline{\bar{\Delta}}$ & 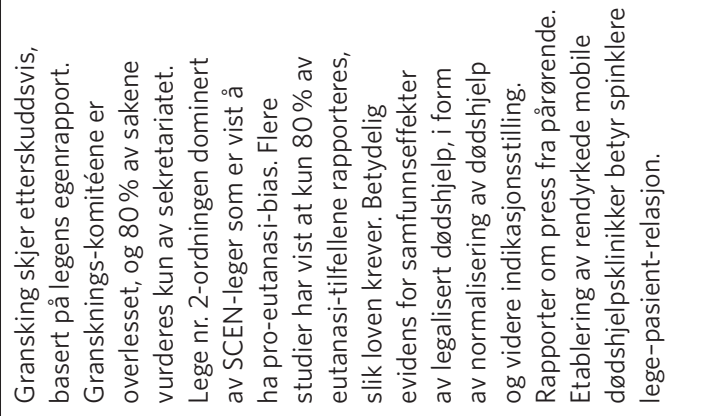 \\
\hline 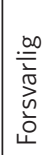 & 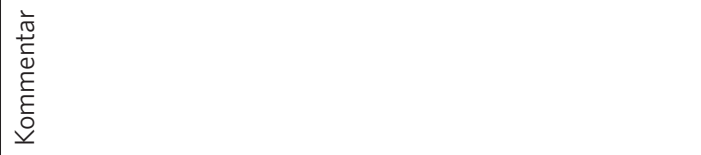 \\
\hline
\end{tabular}




\section{Oppsummering}

Jeg har i dette kapitlet argumentert for at hvis man først skal ha en dødshjelpslov, må den være entydig avgrenset og bygge på kriterier som er så rettferdige og forståelige at de kan respekteres og motstå press om endring. Jeg har vist at manglende avgrensning og rettferdighet kan føre til problemer med forsvarlighet, og at dette er et avgjørende aspekt for hvordan loven blir oppfattet av lovgivere og brukere. Eksisterende dødshjelpslover internasjonalt har store svakheter både når det gjelder entydighet, rettferdighet og evnen til å gi en forsvarlig regulering av dødshjelp. Mitt syn er at dette illustrerer at det er vanskelig, kanskje umulig, å legalisere dødshjelp på en entydig, rettferdig og forsvarlig måte. Det er derfor jeg er motstander ikke bare av å utføre dødshjelp selv, men også av å åpne for at leger som er villige til det, skal få lov å utføre dødshjelp.

Oppsettet i dette kapitlet gir aktører en struktur for diskusjon av eksisterende og potensielle dødshjelpslover. Selv om tilhengere av dødshjelp kan vurdere fakta annerledes enn det jeg har gjort her, gir denne strukturen et grunnlag for å kategorisere fakta og belyse hva vi er uenige om. Hvor stor vekt man vil legge på at en dødshjelpslov er entydig, rettferdig og forsvarlig, blir til slutt et politisk spørsmål. Men politikerne bør utfordres på alle disse tre aspektene, dersom de presenterer en lov for å tillate dødshjelp i de nordiske landene.

\section{Referanser}

Aviv, R. (2015, 15. juni). The death treatment. The New Yorker. Hentet fra https:// www.newyorker.com/magazine/2015/06/22/the-death-treatment

Campbell, J. (2019, 6. februar). Disabled people like me fear legal assisted suicide: It suggests that some lives are less worth living. The BMJ Opinion. Hentet fra https://blogs.bmj.com/bmj/2019/o2/o6/disabled-people-like-me-fear-legalassisted-suicide-it-suggests-that-some-lives-are-less-worth-living/

Canadian Medical Association. (2017). CMA policy: Medical assistance in dying. Hentet fra https://policybase.cma.ca/documents/policypdf/PD17-03.pdf

CBC News. (2018, 31. mai). Lack of palliative care pushing Quebecers toward medically assisted death, College of Physicians says. Canadian Broadcasting Corporation. Hentet fra https://www.cbc.ca/news/canada/montreal/lack-of- 
palliative-care-pushing-quebecers-toward-medically-assisted-death-college-of

physicians-says- 1.4685470

CBC Radio. (2020, 1. februar). Canadians wants expanded access to medical assistance in dying, says Lametti. Canadian Broadcasting Corporation. Hentet fra https://www.cbc.ca/radio/thehouse/canadians-want-expanded-access-tomedical-assistance-in-dying-says-lametti-1.5446731

Council of Canadian Academies. (2018). Medical assistance in dying. The expert panel on medical assistance in dying. Hentet fra https://cca-reports.ca/reports/ medical-assistance-in-dying/

Cousins, B. \& Jones, A. M. (2020, 20. januar). Standoff between B. C. and hospice refusing to offer assisted dying. CTV News. Hentet fra https://www.ctvnews ca/health/standoff-between-b-c-and-hospice-refusing-to-offer-assisteddying-1.4773755

Government of Canada. (2016). Legislative background: Medical Assistance in Dying (Bill C-14). Hentet fra https://www.justice.gc.ca/eng/rp-pr/other-autre ad-am/

Hasham, A. (2017, 19. juni). Advocates hail judge's decision in woman's assisted death appeal. The Star. Hentet fra https://www.thestar.com/news/gta/2017/06/19/ advocates-hail-judges-decision-in-womans-assisted-death-appeal.html

Horn, M. A. (2016). Kan aktiv dødshjelp legaliseres? I R. Førde, M. Kjelland \& U. Stridbeck, Cand.mag, cand.med., cand.jur., cand.alt. Festskrift til Aslak Syse (s. 253-266). Oslo: Gyldendal Norsk Forlag.

Jacobsen, S. D. (2018, 31. januar). In conversation with Dr. Ellen Wiebe - Physicians Advisory Council, Dying With Dignity Canada. Canadian Atheist. Hentet fra https://www.canadianatheist.com/2018/o1/wiebe/

Justice Laws Website. (2016). An Act to amend the Criminal Code and to make related amendments to other Acts (medical assistance in dying). Hentet fra https://laws-lois.justice.gc.ca/eng/AnnualStatutes/2016_3/FullText.html

Kelly, B., Handley, T., Kissane, D., Vamos, M. \& Attia, J. (2019). "An indelible mark". The response to participation in euthanasia and physician-assisted suicide among doctors: A review of research findings. Palliat Support Care. Hentet fra https:// www.ncbi.nlm.nih.gov/m/pubmed/31340873/

Magelssen, M., Supphellen, M., Nortvedt, P. \& Materstvedt, L. J. (2016). Attitudes towards assisted dying are influenced by question wording and order: A survey experiment. BMC Med Ethics, 17. Hentet fra https://bmcmedethics.biomedcentral. com/articles/10.1186/s12910-016-0107-3

Materstvedt, L. J. (1998, 22. oktober). Dødshjelp og selvbestemmelse. Dagbladet. Hentet fra https://www.dagbladet.no/kultur/dodshjelp-og-selvbestemmelse/ 65485855 
Mauron, A. (2015). Acting on a wish to die at the end of life: The Swiss situation. I C. Rehmann-Sutter, H. Gudat \& K. Ohnsorge (Red.), The patient's wish to die. Research, ethics, and palliative care (s. 97-106). Oxford: Oxford University Press.

Moen, O. M. \& Sterri, A. B. (2019). Aktiv dødshjelp. Etikk ved livets slutt. Oslo: Cappelen Damm Akademisk.

Ofstad, J. (2009, 8. juli). På kant med loven. Klassekampen.

Peritz, I. (2015, 22. desember). Quebec's right-to-die law upheld by court. The Globe and Mail. Hentet fra https://www.theglobeandmail.com/news/national/ quebec-government-wins-challenge-on-assisted-dying-law/article27901664/

Plante, C. (2016, 27. oktober). More seeking medical aid to die than expected: Barrette. Montreal Gazette. Hentet frahttps://montrealgazette.com/news/quebec/ more-seeking-medical-aid-to-die-than-expected-barrette

Roest B., Trappenburg, M. \& Leget, C. (2019). The involvement of family in the Dutch practice of euthanasia and physician assisted suicide: a systematic mixed studies review. BMC Med Ethics, 20. Hentet fra https://bmcmedethics. biomedcentral.com/articles/10.1186/s12910-019-0361-2

Ross, W. (2015, 2. desember). Dying Dutch: Euthanasia spreads across Europe. Newsweek. Hentet fra https://www.newsweek.com/2015/02/20/choosing-dienetherlands-euthanasia-debate-306223.html

Schadenberg, A. (2019, 29. april). Health Canada publishes inaccurate and incomplete data on euthanasia in Canada [Blogginnlegg]. Hentet fra ttp:// alexschadenberg.blogspot.com/2019/04/health-canada-publishes-inaccurate-and. html

Staff-Poulsen, I. (2019, 2. februar). Aktiv dødshjelp - «Vedlagte kronikk er kanskje litt kontroversiell - fordi jeg er død». Dagbladet. Hentet fra https://www dagbladet.no/kultur/vedlagte-kronikk-er-kanskje-litt-kontroversiell---fordi-jeger-dod/70706493

Supreme Court of Canada. (2015). Carter v. Canada (Attorney General). Hentet fra https://scc-csc.lexum.com/scc-csc/scc-csc/en/item/14637/index.do

van Marwijk, H., Haverkate, I., van Royen, P. \& The, A. M. (2007). Impact of euthanasia on primary care physicians in the Netherlands. Palliat Med, 21, 609-14.

Vigeland, K. (2009, 26. november). Vil menneskeverdet oversvømmes av eldrebølgen? Fri Tanke. Tilgjengelig fra: https://fritanke.no/vil-menneskeverdetoversvommes-av-eldrebolgen/19.7953

Warnock, M. (2008). A duty to die? Omsorg, 25(4), 3-5. Hentet fra http://eideforlag no/filarkiv/Mary\%2oWarnock.pdf 


\section{Ordforklaringer}

for lengst: för länge sen $(S)$

merkestein: milstolpe (S), milepæl (D)

rart: mærkeligt (D)

reservere seg mot: vægre sig mod (D)

reservasjonsrett: rätt att säga nej av samvetsskäl (S), ret til at sige nej af samvittighetdsgrunde (D)

skråplanseffekt: sluttande plan (S), glidebaneeffekt (D)

uvørne: vårdslösa $(\mathrm{S})$, skødesløse $(\mathrm{D})$

utforbakke: utförsåkning (S), ned ad bakke (D) 



\section{Takk}

Denne boka er laget for å være tilgjengelig kostnadsfritt for alle, gjennom åpen digital tilgang. Den er finansiert med egeninnsamlede midler. Dette har skjedd dels gjennom «crowdfunding», og vi takker alle som har støttet utgivelsen på den måten. Videre takker vi alle organisasjoner og andre som har støttet utgivelsen økonomisk: Fritt Ord, Menneskeverd, Norges Handikapforbund, Norges Kristelige Legeforening, Suomen Kristillinen Lääkäriseura, UlykkesPatientForeningen og Universitetet i Oslo.

Vi er takknemlige for innsatsen til Aksel Braanen Sterri samt en anonym fagfelle. Deres kritiske blikk og tilbakemeldinger har styrket boka. Vi takker forlagsredaktørene Marte Ericsson Ryste, Katia Stieglitz og Simon Aase i Cappelen Damm Akademisk for viktig hjelp og godt samarbeid. Aslak Syse har hjulpet oss med framstillingen av norsk lov i kapittel 3, og Lars Levin og Hampus Erixon har bidratt til ordforklaringene - takk også til dere.

Og sist, men ikke minst, vil vi takke våre tålmodige familier. 



\section{Om forfatterne}

Theo A. Boer är lic.teol. från Uppsala universitet (1995) och dr.teol. från Universiteit Utrecht (1997). Han är professor i hälsovårdsetik vid Protestantse Theologische Universiteit, Groningen, medlem i nederländska halsorådet, och gästprofessor vid University of Sunderland. Från 20052014 var han medlem i en av de fem regionala kontrollkommissioner för utvärdering av eutanasi.

Siri Brelin er overlege i palliativ medisin ved Kreftavdelingen, Sykehuset Østfold, og har en ph.d.-grad i palliativ medisin. Hun er spesialist i allmennmedisin og er godkjent lege innenfor kompetanseområdet palliativ medisin. Brelin har tidligere jobbet ved sykehjem og som fastlege i nær tjue år. Hun deltok i revideringen av Den norske legeforenings retningslinjer for lindrende sedering. Hun har vært leder i Norsk forening for palliativ medisin, og er nestleder i Rådet for legeetikk.

Christian Juul Busch har været hospitalspræst på Rigshospitalet i København siden 1989. Før dette var han præst på Glostrup Hospital og i Vestre Fængsel. Han har været aktiv i grundlæggelsen af den tværfaglige palliative forening i Danmark og var medlem af bestyrelsen til 2011, endvidere har han været medlem af bestyrelsen af den Nordiske tværfaglige palliative forening og dens formand i syv år. Han har 2013-2015 været delvist frikøbt til at være leder af et projekt om »Sorggrupper i folkekirken«. Han har skrevet en del lærebogskapitler om eksistentiel og åndelig omsorg for alvorligt syge og døende og har senest været medredaktør af en større antologi om sorg »Giv sorgen ord. Sorgkultur i forandring«.

Anne-Berit Ekström är med.dr och specialist i barn- och ungdomsneurologi samt chefsläkare och medicinsk rådgivare för Habilitering \& Hälsa i Västra Götalandsregionen. Är kliniskt och forskningsmässigt 
verksam inom området neuromuskulära sjukdomar hos barn- och ungdomar. Samarbetar både nationellt och internationellt med andra forskare och patientföreträdare inom området neuromuskulära sjukdomar och har publicerat ett flertal vetenskapliga artiklar. Sedan 2017 registerhållare för Nationella kvalitetsregistret för barn, unga och vuxna med neuromuskulära sjukdomar i Sverige. Tillsammans med Mikaela Luthman författare till Claphaminstitutets rapport om Oregonmodellen.

Jan Grue er professor i kvalitativ metode ved Institutt for spesialpedagogikk, Universitetet i Oslo, med forskningsinteresser innenfor funksjonshemning, biopolitikk, normalitet og retorikk/diskursanalyse. Han er forfatter av en rekke faglige og litterære utgivelser. Siste bok er novellesamlingen Uromomenter (2019).

Ole Hartling er specialist og dr.med. i klinisk fysiologi og nuklearmedicin, overlæge ved Vejle Sygehus og adjungeret professor ved Roskilde Universitet. Han har fra 1994-1999 været medlem af den danske lægeforenings etiske udvalg, 2000-2007 medlem af Det Etiske Råd i Danmark (formand 2003-2007), 2004-2007 medlem af Unesco's International Bioethics Committee. Han har gennem årene været flittig deltager i den offentlige debat om sundhedspolitiske spørgsmål og om etik.

Søren Holm er læge og filosof. Han er professor i bioetik ved University of Manchester og professor II i medicinsk etik ved Universitetet i Oslo. Han er tidligere medlem af Det Etiske Råd i Danmark og Nuffield Council on Bioethics i Storbritannien og har været præsident for både European Society for the Philosophy of Medicine and Health Care og International Association of Bioethics.

Morten A. Horn er spesialist og ph.d. i nevrologi og overlege ved Nevrologisk avdeling, Oslo universitetssykehus. Han har i flere år deltatt i undervisning ved Universitetet i Oslo, knyttet til etikk ved livets slutt. I perioden 2018-22 er han medlem av Rådet for legeetikk i Den norske legeforening. Han har det siste tiåret vært en aktiv bidragsyter i det 
offentlige ordskiftet om dødshjelp i Norge, ikke minst i Human-Etisk Forbund, hvor han er medlem.

Daniel Joachim H. Kleiven er utdannet siviløkonom fra Handelshøyskolen BI, og er bachelor i religion, kultur og samfunn fra MF vitenskapelig høyskole. Han fullfører en mastergrad i filosofi ved Universitet i Oslo i 2020, og har vært en aktiv samfunnsdebattant om dødshjelp.

Mikaela Luthman, med.dr i medicinsk kemi 1982 vid Karolinska Institutet är invärtesmedicinare och hematolog, diplomerad i palliativ medicin. Hon gick 2004 från akutsjukvården till att arbeta med palliativ medicin, först i slutenvården, sedan 2007 i den avancerade hemsjukvården. Hon har i flera år varit engagerad i dödshjälpsdebatten, i artiklar, föreläsningar och debatter. 2011 var hon medförfattare i Det icke förhandlingsbara, en debattbok mot dödshjälp, och 2017 delförfattare till Claphaminstitutets rapport om Oregonmodellen tillsammans med Anne-Berit Ekström.

Morten Magelssen er førsteamanuensis ved Senter for medisinsk etikk, Institutt for helse og samfunn, Det medisinske fakultet ved Universitetet i Oslo. Han er undervisningsleder i medisinsk etikk på medisinstudiet og hovedredaktør for en fagbok/lærebok i medisinsk etikk, Etikk $i$ helsetjenesten (2020). Videre leder han senterets prosjekt om praktisk etikkarbeid $\mathrm{i}$ helsetjenesten. Han er lege med klinisk praksis fra indremedisin. I perioden 2019-23 er han medlem av Bioteknologirådet. Til forskningsinteressene hans hører blant annet etiske spørsmål ved livets slutt, prioriteringsetikk og klinisk etikkarbeid.

Kalle Mäki är privatpraktiserande allmänläkare och teolog. Han har varit under två perioder, 1995-2005 och 2011-2020, ledamot av Finlands Läkarförbunds etiska delegation och medlem i redaktiosstaben för sex skilda utgåvor av boken Läkaretik som utgivits av Finlands Läkarförbund under dessa år. Han har varit suppleant i den riksomfattande etiska delegationen inom social- och hälsovården ETENE under perioden 2002-2005 och styrelseledamot under perioden 2017-2020 i Pirkanmaan 
Hoitokoti, Nordens första hospice i Tammerfors. Han har varit aktiv i debatten om eutanasi och vård i livets slutskede.

Sven Román är specialist i barn- och ungdomspsykiatri och överläkare. Han har bred erfarenhet av både öppen- och slutenvårdsarbete. Han är en flitig debattör inom psykiatri och dödshjälp.

Fabian Ståhle är civilingenjör, Fellow vid Claphaminstitutet, och medredaktör för rapporten Hotet mot värdigheten. 